\title{
Accessing nature: the battle of the Hurunui River
}

\author{
by
}

\author{
Amanda C. Thomas
}

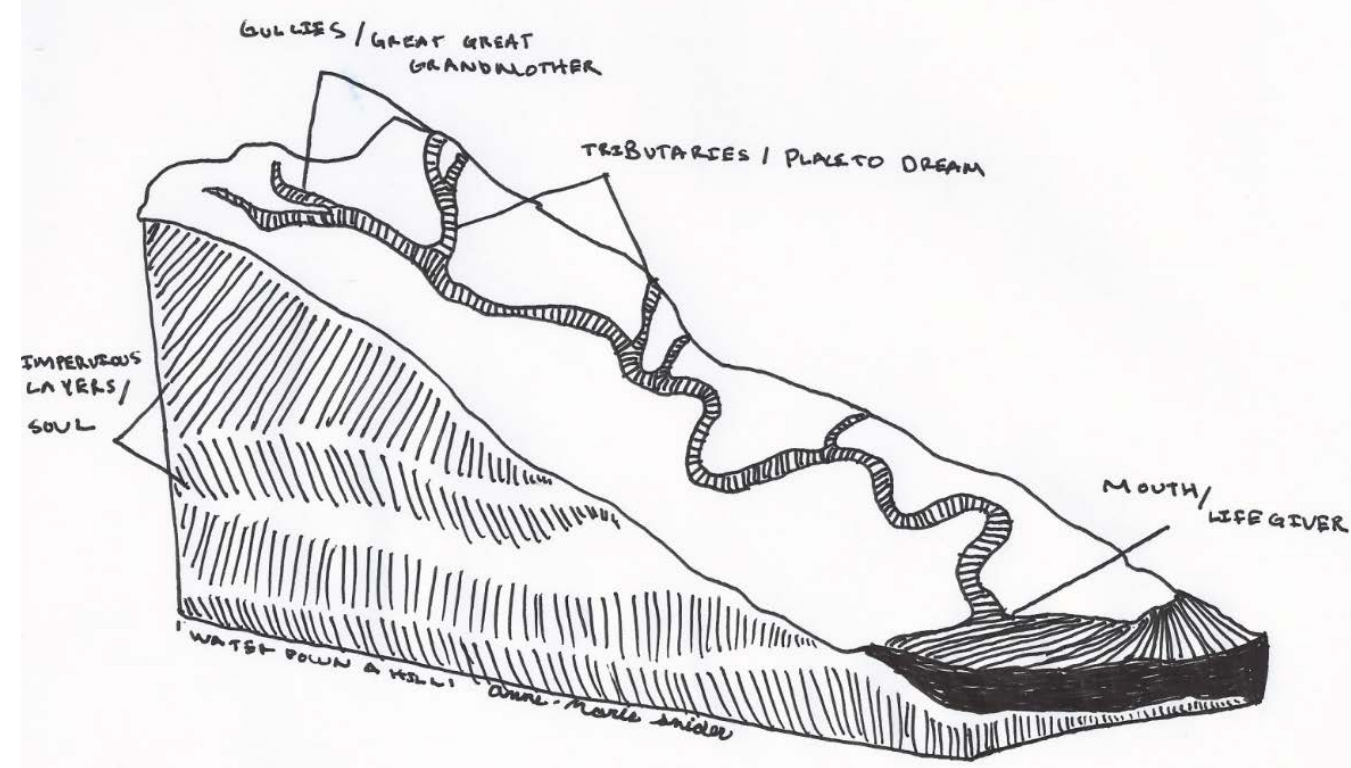

A thesis submitted to the Victoria University of Wellington in fulfilment of the requirements for the degree of Doctor of Philosophy

Department of Geography, Victoria University of Wellington 



\section{Abstract}

People understand their relationship, and that of broader society, with nature in a diverse range of ways. Yet the expression of such diversity is often constrained in decision making processes, and in western contexts, neoliberalised understandings of nature are often privileged. Feminist political ecology provides a nuanced approach to exploring how meanings of nature are made and remade, and how some meanings come to be dominant. An emergent body of political ecology has begun to draw on radical democratic theory to shed light on how this privilege is created and perpetuated in political processes in ways that channel certain outcomes. In extending this engagement between theories, this research explores how different understandings of nature compete in formal and informal political spaces through the case study of a new water management regime.

For more than a decade, debate has raged about whether or not to dam the Hurunui River for irrigation. Such debate about the future of freshwater bodies has characterised politics in the Canterbury region through which the Hurunui flows. Canterbury has seen rapid agricultural intensification that has been enabled by the enclosure of freshwater. However, enclosure has been contested, and this contestation came to a head when, in early 2010, the national government intervened and dramatically reregulated freshwater in the region; elections for the regional council were suspended, access to judicial reconsideration of decisions about the environment were severely narrowed, and processes underway to protect freshwater bodies were interrupted. Promising better environmental democracy, central government, and the appointed officials replacing the elected councillors, endorsed a new freshwater management initiative based on devolved collaboration and consensus building. In response to conflict over the Hurunui River, the 
catchment was the first area in which this initiative was tested, a process that became the case study for this project.

Through a feminist poststructural approach, I conducted and analysed 42 semi-structured interviews with those involved with Hurunui politics, and was a participant observer at 12 meetings of the new collaborative committee for the catchment. I argue that there were multiple processes that worked to channel particular understandings of nature, and facilitate the enclosure of freshwater for economic advantage. This channelling occurred in three key ways. Firstly, reregulation in Canterbury removed many democratic rights, limiting opportunities for participation in water politics. Secondly, the devolved collaborative and consensus based water committee was constrained by targets and discourses that determined that more water needed to be enclosed to serve a neoliberal growth agenda. Thirdly, community was privileged as a scale of democracy. As a result, narrow constructions of community belonging and performance remained unexplored, and these constructions inhibited public debate and limited possibilities to articulate and explore difference. I argue that such everyday experiences of power and constrained agency constitute an important dynamic of nature politics. There were, however, hopeful aspects of the new regime. An emphasis on dialogue led to transformative social learning, particularly about Ngāi Tahu, the Māori iwi (tribe) with traditional authority over the region, and the ways the iwi negotiated and enacted a relational ethics with the river. This study argues that considerations of power must be at the forefront of democratic design and uneven power relations need to be engaged with in such a way that multiple understandings of nature and society can be articulated and seen to be legitimate. Such an approach provides possibilities for political space in which to reimagine environmental futures and contest the dominance of neoliberal natures. 


\section{Acknowledgements}

This thesis was very much a collective effort, and there are many people to thank for sharing their knowledge, and for their encouragement and generosity.

First of all, thank you to the research participants for your time, energy, patience and contribution to this work.

I received scholarships from Fish and Game in 2011, and the New Zealand Federation of Graduate Women Charitable Trust in 2012. I am extremely grateful to both organisations for this funding. Neither group, in their capacity as scholarship providers, influenced the shape and scope of this research in any way.

I've been part of a few groups that have been instrumental in extending my thinking, and connecting me with fantastic people. In 2013, I attended the $4^{\text {th }}$ Antipode Institute for Geographies of Justice in Durban. It was an incredible opportunity to make international connections and learn from others, and I was very lucky, and grateful, to be selected to take part. The New Zealand Geographical Society Postgraduate Network and Victoria University's Spatial Theory and Social Praxis Research Group were invaluable to my PhD experience, as was We Are the University (WATU). Being part of WATU helped me to think through issues of access to tertiary education, as well as processes of neoliberalisation and securitisation at Victoria University and within the Aotearoa New Zealand tertiary sector more generally, and was enormously challenging and inspiring. Thank you also to the tutors and students of Geography/Environmental Studies 114 over the past four years you have all played a part in developing my passion for learning. 
I am so grateful to all of the staff in the Geography department at Victoria who have supported me and encouraged me onwards. I've been very lucky to have such enthusiastic and compassionate people around me. Special thanks to Marcela Palomino-Schalscha (for some particularly good pep talks), Sara Kindon, Bethany Haalboom, Mairéad de Róiste, and Nicki Wrighton for your encouragement and empathy. You're such an intelligent and generous bunch of women! The administrative staff in the School of Geography, Environment and Earth Sciences do an amazing job of supporting students - thank you Cheryl Johansen, Kate King and Alan Ball.

To Deb Maxwell - thank you for your friendship and guidance, and for sharing your computer genius. Thanks also to Morgan Hanks for reading a chapter and being meticulous about grammar (all mistakes are mine though!), and Andrew Rae for helping me to make maps.

My deepest, deepest thanks to my friends who have been incredibly patient and generous. In particular, Emily Hume, Megan Willetts, Alexandra Frank, Rowen Steenkamp, and Catherine Bisley have kept me sane (most of the time) and feeling loved (all of the time). Thank you to Anne-Marie Snider for your beautiful cover art, for reading a chapter, and for being a supportive, perceptive and hilarious friend. I am especially grateful to Susie Keenan. For the past 18 months, Susie has nurtured me through this project - thank you for feeding me, for closing my curtains when I'm not home before dark and for understanding self-deprecating humour. The depth of your care and kindness for other people is a rare and precious thing.

I have had the privilege of sharing an office with the extremely talented Gradon Diprose. He has oscillated between quiet workmate, counsellor, chocolate biscuit provider, friend, mentor and collaborator. It's truly been a blessing to learn next to him. Thank you for being my academic husband Grady.

I'm very grateful to my wonderful supervisors, Sophie Bond and Andrew McGregor, who have both continued to work with me while their lives have taken them away from Wellington. Andrew, thank you for your deeply perceptive, generative and invaluable feedback. Sophie, I have been so incredibly lucky to have you as my primary supervisor. You knew exactly what to say to keep me going and were a patient and engaged ear when I needed to share some outrage. You've been incredibly generous with your time and 
knowledge and have encouraged me way beyond what I ever thought I could do - thank you so much!

I've been blessed with an incredibly supportive family. I'm very grateful to Gail Ferguson, Chris Dawson and Jeannie and Chris Sales for caring for me. Thank you to my brothers, Angus and Jack, who constantly challenge me and push me to explore beyond what I think I might know. My Granny T, Marjorie Thomas, looked after me during my fieldwork - this thesis created the opportunity for me to sit and listen to my Gran, and learn about what an amazing woman she is. Thank you for supporting me Gran. My Dad, Dugald Thomas, was the first person to suggest that I do a PhD. I was 18 and laughed at him. I don't know if you were perceptive, or just wishful Dad, but l've been so lucky to have you in my corner encouraging me along. And Carol Ferguson, my Mum, has been incredibly inspiring to me. She is an exceptionally ambitious woman and I am so proud to have such a hard-working, generous, and loving parent and friend. Thanks Mum.

And finally, my partner and best pal Daniel Sales. Sales has been unfailingly supportive through the extreme highs and lows of this project - I'm so, so thankful to him for getting me through. I can't imagine a more hilarious, loving and inspiring person to be with.

Somehow I've managed to gather amazing people around me. This project was possible because of them and I am truly grateful. 


\section{Contents}

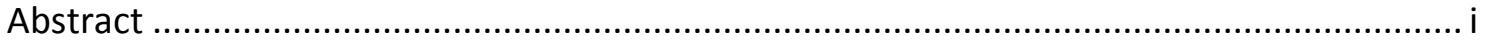

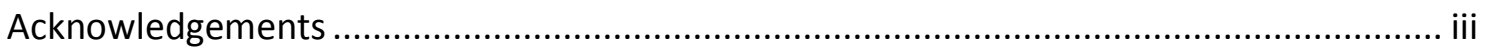

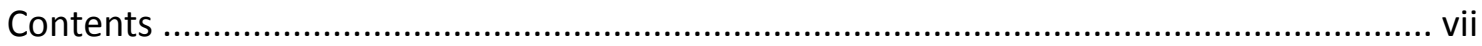

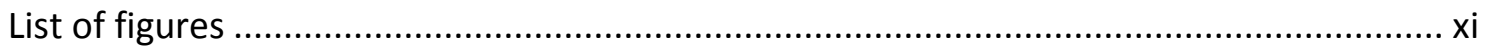

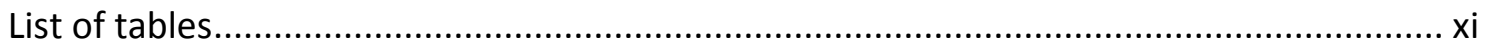

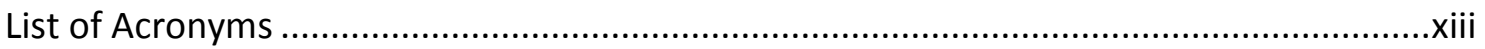

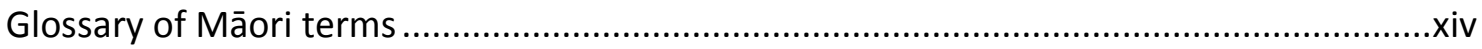

1 Introduction: political ecology, democracy and freshwater ....................................... 1

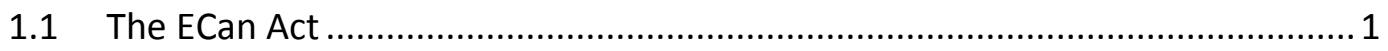

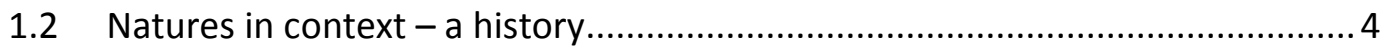

1.2.1 Canterbury and the primary industry-based economy ..................... 9

1.2.2 The Hurunui River .................................................................. 13

1.2.3 Research questions ............................................................ 17

1.3 Theoretical framework - diverse political ecologies ....................................... 18

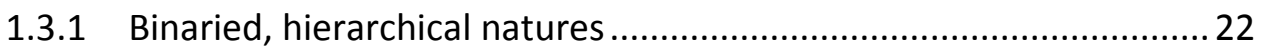

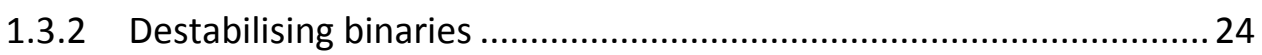

1.3.3 Democracy and the "stuff" of politics................................................26

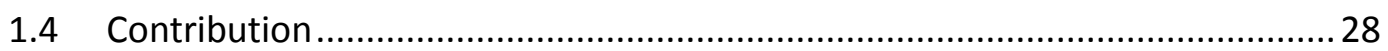

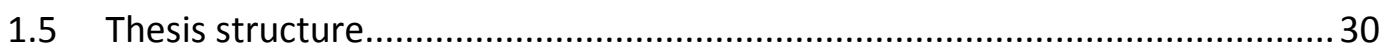


2 Methodologies: the tricky navigations of doing reflexive, responsible and accountable research

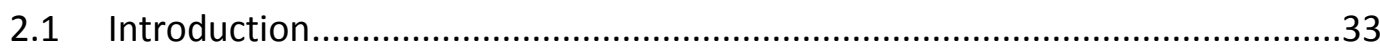

2.2 Feminist poststructuralism - exploring meaning and destabilising truth ........34

2.2.1 Navigating the co-constituted field ................................................36

2.2.2 Feminist, (post)colonial and decolonising ethics - tricky

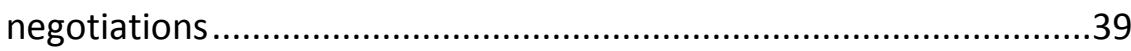

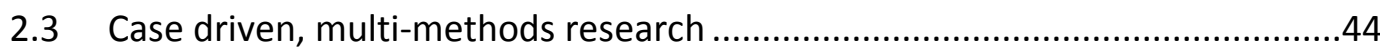

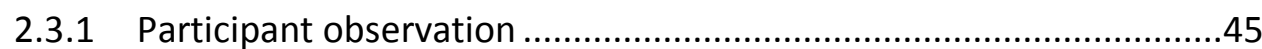

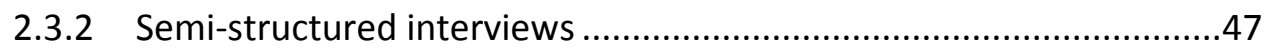

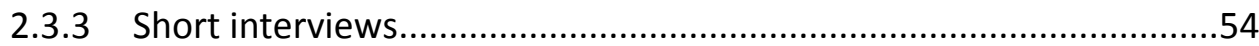

2.4 Responsive and accountable research - analysing and writing ......................55

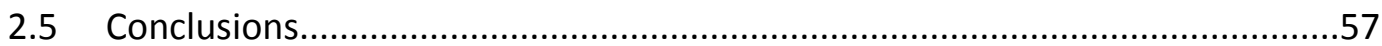

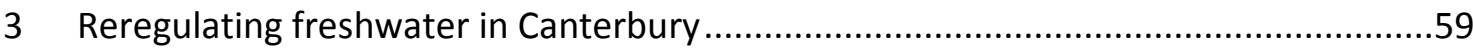

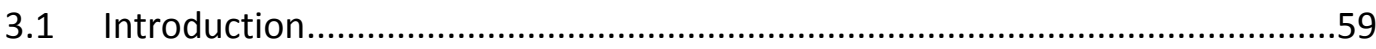

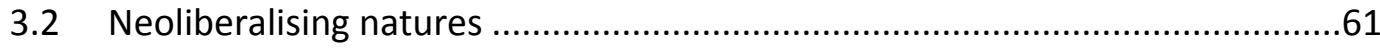

3.2.1 Neoliberalisms - ideology, reform and practices...........................61

3.2.2 Neoliberalisms and the biophysical world ...................................64

3.3 The work of neoliberal environmental governance in Aotearoa

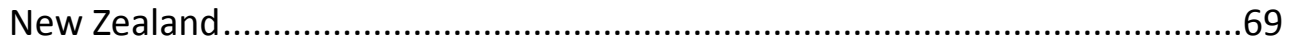

3.3.1 Environmental reform in Aotearoa New Zealand ...........................69

3.3.2 The ECan Act - reregulating for the accelerated enclosure of nature .73

3.3.3 Making sense of the ECan Act - extending the state of exception....76

3.3.4 Caring capitalism and inevitable neoliberalisms? ...........................81

3.4 Conclusions

4 Post-politicising processes in environmental governance - collaboration and consensus in the Hurunui Waiau catchment 
4.1 Introduction

4.2 Changing conceptions of democracy - political ideology, power, and postpolitics

4.3 The Canterbury Water Management Strategy - eliminating conflict and ensuring "more water"

4.4 Creating responsibility within a "more water" paradigm, and circumventing collaboration

4.5 Collaboration in the state of exception as a post-political process.

4.5.1 Troubling post-politics - social learning, challenging rationalities, and destabilising legitimacy....

4.6 Cultivating genuine environmental democracy.

5 Community construction and performance - shaping the Hurunui River debate ..... 125

5.1 Introduction

5.2 A critical approach to community based decision making

5.2.1 Circulating power and community.

5.3 Experiencing community across forms of difference
5.3.1 Seeking economic autonomy - rural discourses of independence

5.4 Sites of discipline - good citizenship in a neoliberalising rurality

5.4.1 Sites of discipline - the home and a changeable social fabric

5.5 Narrating everyday post-politicisations

5.6 The effect of bounded notions of community on political spaces

5.7 Successful community based decision making?

5.8 Post-politicising communities and the environment - critical approaches.

6 Reimagining environmental futures - relational ethics, Ngāi Tahu and the HWZC

6.1 Introduction 157 


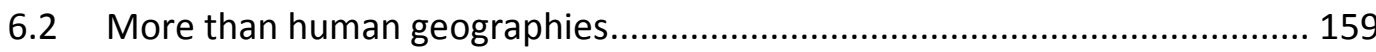

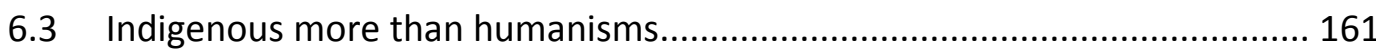

6.4 Ngāi Tahu and environmental decision making - everything is related.

6.4.1 Ngāi Tahu worldviews and a corporatised iwi structure..................168

6.5 Contesting nature/society binaries in (post)colonial places....................... 174

6.6 Representation and recognising rights - failure in the Hurunui District ....... 178

6.6.1 Representation and recognising rights - the CWMS and HWZC .182

6.6.2 Beyond the HWZC - decolonising decision making ......................186

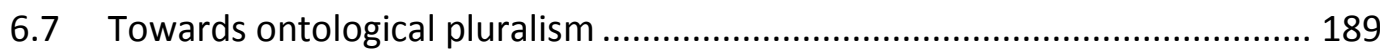

7 Environmental democracy - accessing the Hurunui River .......................................193

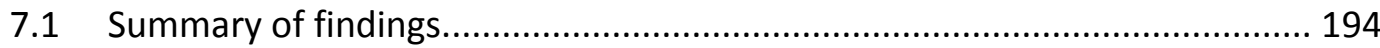

7.2 State of the environment - post-politicising processes and political

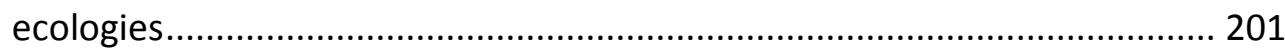

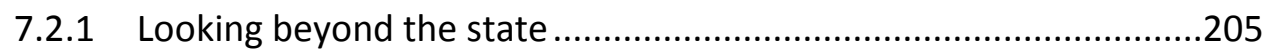

7.3 Learning to live together - geographies of coexistence .............................. 207

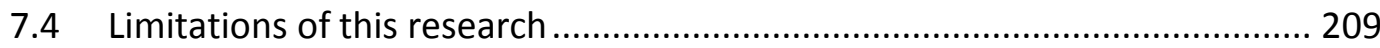

7.5 Contributions and future research....................................................... 210

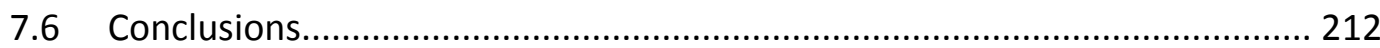

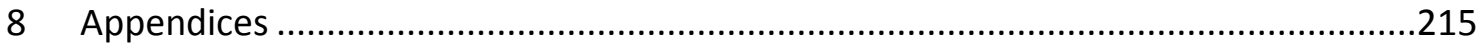

8.1 Appendix A - Human ethics approval ................................................... 215

8.2 Appendix B - Information and consent forms ........................................ 217

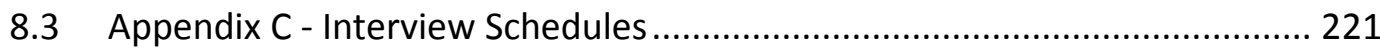

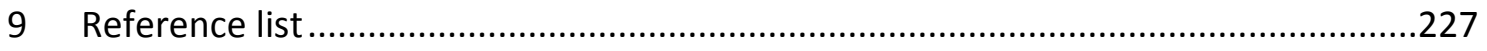




\section{List of figures}

Figure 1 The Canterbury Region and Hurunui District territorial boundaries. 10

Figure 2 The Hurunui River below Lake Sumner in late spring (Source: Amanda Thomas, 2011)

Figure 3 The Hurunui District with towns and large rivers 15

Figure 4 The Hurunui District with the Waitohi storage scheme highlighted 103

Figure 5 The process of developing water regulation in the Hurunui District. 105 Figure 6 Abridged organisational structure of Ngāi Tahu 1998 (adapted from Cant, 2005).

\section{List of tables}

Table 1 Table of participant codes and descriptions and dates interviewed 49

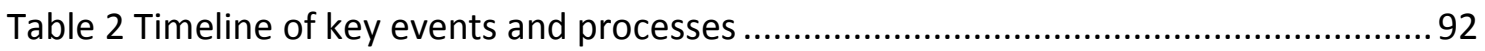

Table 3 Steps leading to the CWMS (adapted from Lomax et al., 2010) 96 
Figure 1 The Canterbury Region and Hurunui District territorial boundaries 10

Figure 2 The Hurunui River below Lake Sumner in late spring (Source: Amanda Thomas, 2011)

Figure 3 The Hurunui District with towns and large rivers. .15

Figure 4 The Hurunui District with the Waitohi storage scheme highlighted 103

Figure 5 The process of developing water regulation in the Hurunui District. .105 Figure 6 Abridged organisational structure of Ngāi Tahu 1998 (adapted from Cant, 2005). 


\section{List of Acronyms}

$\begin{array}{ll}\text { ECan } & \text { Environment Canterbury } \\ \text { CWMS } & \text { Canterbury Water Management Strategy } \\ \text { HDC } & \text { Hurunui District Council } \\ \text { HWZC } & \text { Hurunui Waiau Zone Committee } \\ \text { HWP } & \text { Hurunui Water Project Ltd } \\ \text { HWRRP } & \text { Hurunui Waiau River Regional Plan } \\ \text { LAWF } & \text { Land and Water Forum } \\ \text { MAF } & \text { Ministry for Agriculture and Forestry } \\ \text { NTP } & \text { Ngāi Tahu Property } \\ \text { PHWRP } & \text { Proposed Hurunui Waiau Regional Plan } \\ \text { RMA } & \text { Resource Management Act 1991 } \\ \text { WCO } & \text { Water Conservation Order } \\ \text { ZIP } & \text { Zone Implementation Programme }\end{array}$




\section{Glossary of Māori terms}

$\begin{array}{ll}\text { Hapū } & \text { Sub tribe } \\ \text { Hāpua } & \text { Lagoon } \\ \text { Inanga } & \text { Whitebait, a small native fish } \\ \text { Iwi } & \text { Tribe } \\ \text { Kāhu } & \text { Harrier hawk } \\ \text { Kaimoana } & \text { Seafood } \\ \text { Kaitiaki } & \text { Guardians with the responsibility of kaitiakitanga } \\ \text { Kaitiakitanga } & \text { Guardianship and resource management } \\ \text { Ki Uta Ki Tai } & \text { Mountains to the sea, a philosophy towards the biophysical world } \\ \text { Kō iwi tangata } & \text { Human remains } \\ \text { Mahinga kai } & \text { Food, resources, and the areas they're sourced from } \\ \text { Mana } & \text { Respect, dignity, influence } \\ \text { Mana whenua } & \text { Customary authority, and responsibilities to land } \\ \text { Manu } & \text { Birds } \\ \text { Marae } & \text { The area in front of a meeting house, often used to refer to the } \\ \text { complex and surrounds of the meeting house } & \text { The life essence, force of all things } \\ \text { Papatipehā } & \text { A Māori tribe with traditional governance over much of the South } \\ \text { Island of Aotearoa New Zealand } \\ \text { Mauri }\end{array}$




\begin{tabular}{ll} 
Pūtea & Funds, account \\
Rangatira & Chief, male or female \\
Rangatiratanga & Authority, sovereignty \\
Ranginui & Sky Father \\
Rūnanga & An assembly of people with traditional governance over particular \\
& areas \\
Takiwā & Area or district, traditional territory \\
Tangaroa & God of the sea \\
Tangata whenua & People of the land, with territorial rights to the land \\
Taonga & Treasure, both tangible and intangible \\
Tipuna & Ancestors \\
Tikanga & Customary values and practices \\
Tohunga & A person with expertise and/or a spiritual leader \\
Tuna & Eel \\
Wāhi taonga & Treasured place, location \\
Wāhi tapu & Sacred places of immense importance \\
Wairua & Spirit or spiritual essence \\
Whānau & Family \\
Whānui & Community \\
Whakapapa & Genealogy, cultural identity, understanding of the relationships \\
& between people and the natural world \\
\hline
\end{tabular}

(Sources: Te Rūnanga o Kaikōura, 2007, interviews for this research; Tipa et al., 2009) 



\section{Introduction: political ecology, democracy and freshwater}

\subsection{The ECan Act}

On the $30^{\text {th }}$ of March 2010, the Ministers for the Environment and Local Government emerged from a meeting with the elected regional council representatives for Canterbury, Aotearoa New Zealand, and announced that the councillors were being fired by the central government. The councillors, the ministers claimed, had been too slow in allocating freshwater for agricultural irrigation, potentially costing the whole country millions of dollars in lost earnings (Gorman, 2010). The next day special legislation was passed through the national parliament in a thirty hour period, circumventing standard public engagement processes. The new law, the Environment Canterbury (Temporary Commissioners and Improved Water Management) Act (or the ECan Act), changed key aspects of environmental law in the region of the South Island, and was exceptional in its scope. It denied people in Canterbury the same rights to access the Environment Court as in the rest of the country, suspended regional elections for three and half years, and changed the criteria guiding, and process for securing, national protection status over freshwater bodies. New criteria introduced economic considerations to a protection tool normally assessed on intrinsic values of rivers and lakes. The ECan Act was, according to environmental and public law scholars, unconstitutional (Brower, 2010b; Joseph, 2010) and the intervention unprecedented. ${ }^{1}$

\footnotetext{
${ }^{1}$ Although Aotearoa New Zealand doesn't have a written constitution, there is a body of law that forms the constitutional arrangements. The ECan Act was unconstitutional because it is not general in operation so people do not have equal protection under the law, the Act is retrospective, and it constrains access to the courts. These constitutional breaches were, however, legal because Parliament is sovereign (Brower, 2010b).
} 
Some welcomed the change and the possibilities for decisions about freshwater to be made quickly without drawn out judicial processes. Others, deeply unhappy about central government's action, declared the 'death of democracy' and saw the intervention as motivated by greed (TVNZ, 2010). For some, water is first and foremost Canterbury's gold; once enclosed it can be used for agricultural irrigation and therefore generate economic growth. Such economic growth is seen to underpin good quality of life and vibrant communities. For others, rivers and lakes are primarily something else - a family member, site of recreation or place of cultural practice - that hold value that can't be represented in monetary terms. As the Minister for the Environment at the time summarised, rivers are a 'core part of New Zealand's spirit, New Zealand's sense of identity. But equally it's true that plentiful freshwater is at the core of New Zealand's competitive advantage' (quoted in White, 2010, p. 65).

These different understandings of freshwater led to intense division and disagreement about the future of rivers and lakes in the region I grew up in; the debate increasingly defined local politics and you couldn't pick up the local newspaper without reading about contestation over freshwater. At times the contestation about what freshwater means was exasperating, and at other times unnecessarily caustic. The Ministers for the Environment and Local Government had described the dissensus in Canterbury as untenable and the council as dysfunctional, divided over water. Therefore, they argued, the dramatic changes made through the ECan Act were necessary. However, such contestation is important; if spaces for dialogue and disagreement are limited, how do people learn about each other and the different meanings rivers hold, and how can inclusive decisions be made about the future of freshwater bodies (Mouffe, 2000)? Into this formal democratic deficit, central government supported the Canterbury Water Management Strategy (CWMS), an initiative that would see decision making devolved to catchment based committees. These committees would take responsibility for local waterways and collaborate to reach consensus decisions. The chair of the ECan commissioners, appointed by the government to replace the elected councillors, claimed that this devolved decision making would offer better democracy than the systems and institutions that existed prior to the legislative reform because the public would be more involved in decisions (The Press, 2010). The first catchment in which this scheme was rolled out was the Hurunui Waiau in North Canterbury. This catchment was chosen 
because of a deep, long running conflict over the Hurunui River, namely whether it should be dammed for agricultural irrigation, or not.

The rapid changes in environmental democracy in Canterbury provide an important case study at a time when there are growing questions about the nature of democracy broadly, and how people access decision making about the environment (see Oram, 2013; Salmond, 2013; Swyngedouw, 2007, 2011b). There is contestation over the meaning of democracy; conceptualisations vary from democracy as the presence of a set of institutions through which certain values (liberty, equality, justice) are pursued, through to democracy as an inclusive process of navigating difference and conflict (see Benhabib, 1996b). Throughout this thesis I understand democracy as a process that in its ideal form creates both formal and informal spaces for disagreement, and is based on the recognition that many differences are irreconcilable and therefore require ongoing engagement and respectful negotiation (see Mouffe, 2000). An endpoint of these processes - reached through consensus or a victory of one party over another - is not desirable or possible because of the tensions inherent to liberal democracy. Traditions of liberalism are based on human rights and individual liberty, and democracy is rooted in equality and popular sovereignty (Mouffe, 2000). These paradoxical aims cannot be resolved; contestation between these competing ideas is what makes liberal democracy promising in that ongoing negotiations between them force a degree of balance between individual freedoms and equality.

The foundation of this vision of democracy is a constant questioning of power relations and inequality. For decision making about the environment, democracy that enables a questioning of power is important to creating space in which multiple ways of valuing nature can be articulated and no one nature discourse gains hegemony. However, in many settings, neoliberalised understandings of nature - as separate from society, as a series of objects primarily valuable for economic growth - have come to dominate decision making (Swyngedouw, 2007, 2011b, 2013b). A number of theorists have described a range of processes that enable and cultivate the dominance of neoliberalisms (Gunder, 2010; Mouffe, 2000, 2005; Purcell, 2009; Žižek, 1999b), and as a result there is a narrowing of political spaces in which to articulate and enact different environmental futures (Swyngedouw, 2009). This thesis, therefore, explores the power relations circulating through, and treatment of, diverse understandings of nature within reregulated 
freshwater decision making in Canterbury. I am centrally concerned with contestation over accessing the Hurunui River; access both in the sense of being able to be in, on or around the river, as well as access to formal and informal river politics and decision making.

In this chapter, I contextualise current environmental politics in Aotearoa New Zealand (adopting a particular (post)colonial ${ }^{2}$ focus), and freshwater politics in Canterbury. This section provides important background to issues of accessing natures; aspects of it will be elaborated on in later chapters. I then describe my theoretical framework - political ecology - and why this is a useful framework through which to explore environmental democracy, before explaining the contribution this project makes. Finally, I describe the structure of the remainder of this thesis.

\subsection{Natures in context - a history}

In order to explore current environmental democracy in Aotearoa New Zealand, it's important to situate it within the country's colonial history. ${ }^{3}$ Aotearoa New Zealand was settled around 1000AD by Polynesian people who came from Hawaiki, a place that doesn't exist on maps but in the origin stories of Māori, the people who settled throughout Aotearoa. Ngāi Tahu, an iwi (tribe) that has authority over the majority of the land in the South Island, formed out of three waves of southern migration - the Waitaha iwi, Kati Māmoe, and the descendants of Tahu Pōtiki, Ngāti Kuri and Ngāi Tūhaitara (Te Rūnanga o Ngāi Tahu, no date-b). Over time tangata whenua (people of the land) developed complex ways of managing and making decisions about the biophysical world, and practices and tools were refined through hundreds of years of Ngāi Tahu ${ }^{4}$ settlement (Hemmingsen, 2005). In particular, freshwater bodies hold spiritual, cultural and material significance. Rivers form part of whakapapa (genealogy, cultural identity, understanding of the

\footnotetext{
${ }^{2}$ Parentheses are used throughout this thesis when describing (post)colonialism in recognition that we are not yet beyond colonialisms; unequal colonial power relations persist, and the effects of colonial practices continue to be experienced (Porter, 2010).

${ }^{3}$ The following is one (my) version of history, yet I acknowledge that there are many other histories.

${ }^{4}$ Some southern Māori dialects pronounce "ng" as "k". Therefore, Ngāi Tahu is often spelled and pronounced Kāi Tahu. In this thesis, I follow Te Rūnanga o Kaikōura spelling and pronunciation which includes "ng" phonemes.
} 
relationships between people and the natural world). Water is therefore a 'taonga (treasure) of utmost importance to Māori' (Pauling, 2008), and water health is vital to the health of the people.

During the late 1700s, European sealers and whalers began to settle in Aotearoa; Māori negotiated resource use rights for the settlers, and there was increasing intermarriage (Kaikōura District Council, 2008). However, conflict grew as the European population increased and placed pressure on Māori resource management. European powers viewed the settlements in Aotearoa New Zealand as increasingly wild and unruly. Initially reluctant to become involved with a series of small and isolated islands, in the late 1830s the British Government, threatened by French land claims in Akaroa, Canterbury, and wanting to create a degree of order, moved towards formal colonisation (Goodall, 2005). In 1840 the British Colonial Office sought to secure sovereignty over the territory through a treaty. On 6 February 1840 Te Tiriti o Waitangi, the Treaty of Waitangi, was signed by representatives of the British Crown and 45 Māori rangatira (chief, both male and female). Copies were then taken around Aotearoa New Zealand and Te Tiriti was ultimately signed by over 500 Māori representatives. However, the document had key differences between the English and the Māori language texts. The seven Ngāi Tahu chiefs that signed it in 1840 understood the agreement as 'a convenient arrangement between equals', rather than a ceding of sovereignty as the English version indicated (Te Rūnanga o Ngāi Tahu, no datea).

In its dealings with Ngāi Tahu, and many other iwi throughout the country, the Crown failed to act in good faith after the signing of Te Tiriti. Between 1844 and 1864, 34.5 million acres passed from Ngāi Tahu to the Crown, an area representing more than half the total land area of Aotearoa New Zealand. The area was bought for just $£ 14,750$ by the Crown (Waitangi Tribunal, 1991), who then sold the land to those who would clear bush and cultivate grasslands. Ngāi Tahu entered the arrangement on the basis that Pākehā ${ }^{5}$ and Māori would share resources and '[e]ach would learn from the other' (Waitangi Tribunal, 1991). The iwi expected 'to be provided with, or to have excluded from the sales,

\footnotetext{
${ }^{5}$ Pākehā is a commonly used Māori term that refers to New Zealanders of European descent. Although its use is contested within ongoing negotiations of identity politics in Aotearoa New Zealand (see Jackson, 1998), I follow Spoonley (1995) and use the term Pākehā as a way to acknowledge Aotearoa's ongoing (post)colonial reality.
} 
adequate endowments that would enable them to engage in the new developing pastoral and commercial economy' (Waitangi Tribunal, 1991). However, the Crown failed to adequately provide these conditions. Instead private property rights were increasingly privileged over the commons; Ngāi Tahu were excluded and penalised for accessing traditional food sources, and carrying out rituals and customs designed to preserve plant, sea, river, and bird life (Taiepa et al., 1997; Waitangi Tribunal, 1991). This was devastating for the tribe. Accompanying this alienation from the land, the Tohunga Suppression Act 1907 attempted to silence tohunga (people with expertise or spiritual leaders), affecting the communication of Māori ways of understanding and being.

Crown actions have long been contested by Ngāi Tahu. For instance, in 1876 a fund, Te Kereme, was established to campaign for an investigation into land losses (Wanhalla, 2007). Any attempts by the courts to carry out such an investigation were, however, blocked by government decisions or changes to the government (Te Rūnanga o Ngāi Tahu, no date-a). The land brought into question by Te Kereme and other efforts was vital to a state economy firmly based on agriculture and horticulture, and the state didn't want this threatened by claims challenging existing ownership arrangements (Memon \& Kirk, 2012). Instead, the Canterbury region became an agricultural heartland, with the ownership of vast expanses of grass and grains held by Pākehā.

The Canterbury landscape is defined by the Southern Alps that form the spine of the South Island. Canterbury is in the lee of the mountains, and its climate is therefore shaped by a nor'west foehn wind, a drying wind. This wind meant that as native scrub was cleared from the plains by Europeans, dryland farming dominated agriculture rather than more intensive farming, such as dairying. By 1895 refrigerated transportation opened up international export markets for agricultural products such as meat, butter and cheese, creating new opportunities for an economy based on primary industries. Bush clearance and pastoralism was a hard won, and very unstable and incomplete, "victory" over nature (Cumberland, 1941, p. 529). The work to alter and tame the landscape in the interests of this economy:

is at one and the same time the essential theme of the history of New Zealand ... It is the basis of the farm economy of the Dominion and is fundamental to the country's export trade, wealth, and high standard of living (Cumberland, 1941, p. 529). 
For decades, hierarchical understandings of both indigenous plants and Indigenous people remained central to the country's politics, evidenced for instance through a government policy of Māori assimilation, a policy given effect through the formal banning of the Māori language in schools and official encouragement of Māori urbanisation, detaching many Māori from their iwi and whanau (family) (Goodall, 2005). However, after decades of activism, Māori claims against the state gained increasing purchase in the 1970s, and Te Tiriti o Waitangi, by now a dishevelled document that had largely remained forgotten, became a symbol for the movement. Situated within a Māori cultural renaissance and activist demands for state action, Parliament passed the Treaty of Waitangi Act 1975, which established the Waitangi Tribunal, and facilitated investigations into Treaty breaches after 1975.

As well as being a critical time for (post)colonial relations, the 1970s and 1980s were significant in terms of freshwater led economic development. Between 1975 and 1984, Aotearoa New Zealand was governed by the right of centre National Party that, at the time, was notable for its centralised approach to decision making. This centralised approach and investment in large infrastructure saw an acceleration of hydroelectric dam development, particularly in the South Island, development that had begun in earnest in the 1950s. The enclosure of this water for power generation has 'underpinned much of the country's development' (Parliamentary Commissioner for the Environment, 2012, p. 11). However, decisions to dam major rivers were taken with little opportunity for formal public input and where necessary, laws were changed to facilitate the construction of dams. The controversy generated by this approach led to the creation of Water Conservation Orders in 1981, through an amendment to the Water and Soil Conservation Act, which could be placed over rivers with outstanding wild or scenic value, and prohibit alteration and water abstraction (Parliamentary Commissioner for the Environment, 2012).

Under the Third National Government (1975 - 1984), the economy was very tightly controlled, and when the effects of oil shocks began to be felt, growth stagnated and unemployment rose, voters turned to the social democratic Labour Party in 1984. At the time, the Labour Party was divided between those committed to traditional Labour values focused on workers and a socialist orientation, and those desiring radical neoliberal reform. Neoliberalisation largely won out and New Zealand became subject to some of the 
most rapid and far reaching neoliberal reforms anywhere (see Britton et al., 1992). From 1984 through to the 1990s under a different government, state owned assets were privatised, subsidies removed, governance arrangements reformed, and social welfare retracted (Kelsey, 1995). Since this time neoliberalisms have been entrenched by successive governments.

The Fourth Labour Government (1984 - 1990) was also responsible for empowering the Waitangi Tribunal to investigate pre-1975 Treaty transgressions. Soon after this extension Ngāi Tahu lodged a claim, and the Tribunal set about investigating almost 150 years of iwi grievances against the Crown. After extensive research, the Tribunal released a report in 1991 that made recommendations on which to base the ensuing iwi-Crown negotiations to reach a settlement. Following the report, a Ngāi Tahu delegation began formal dialogue with the Crown. Despite obstructions by the Crown, and legal manoeuvring by Ngāi Tahu (O'Regan et al., 2006), by 1997 a Deed of Settlement had been signed and the following year the Ngāi Tahu Claims Act was passed, giving effect to the Deed. According to the agreement, Ngāi Tahu received an apology from the Crown, were given \$170 million (a fraction of the current valuation of lands lost), granted mechanisms to buy Crown assets, and the Crown acknowledged Ngāi Tahu's special relationship with the environment. This acknowledgement was also articulated through newly established advisory roles to the Department of Conservation for Ngāi Tahu, recognition of seasonal occupation sites for mahinga kai (food, resources, and the areas they're sourced from), and new tools to place Ngāi Tahu within decision making about places of particular significance.

Goodall (2005) argues that the Treaty settlement process has cultivated the conditions for Māori to pursue self determination. However, Mutu (2010, p. 183) states that the settlements negotiated by individual iwi 'remain neither just nor fair, delivering only a small fraction of what was stolen from each iwi and providing little or no compensation for the extensive damage done to Māori throughout the country since 1840' (see also Chapter 6). Furthermore, (post)colonial relationships remain somewhat fragile. In 2003, conflict erupted over customary ownership of the foreshore and seabed, and parliamentary responsibilities to Māori. The Waitangi Tribunal investigated the issue but the Labour Government dismissed recommendations made by the Tribunal and vested ownership for the foreshore and seabed in the Crown (Inns, 2005). The whole debate went to the heart of (post)colonial nature/society relations, particularly the manner in which Eurocentric 
worldviews, articulated through the notion of exclusive private property ownership, enjoy legislative status that Māori worldviews do not.

For Ngāi Tahu, settlement has been enabling in many ways, particularly through greater revenue generation, much of which is channelled into social development programmes. Iwi land holdings are a key part of growing the tribe's revenue, which has meant that Ngāi Tahu is a significant actor as the Canterbury region negotiates land use and freshwater allocation.

\subsubsection{Canterbury and the primary industry-based economy}

Since cereals and grasslands replaced indigenous flora, agriculture has been the mainstay of the Canterbury region and Christchurch, the regional centre and third largest city in the country (see Figure 1); indeed $23 \%$ of Aotearoa New Zealand's total farmland is within its regional boundaries (Creech et al., 2010).

However, crop and sheep and beef farmers have seen fluctuating and unpredictable returns, and many struggled to compete in the free trade economy created during the neoliberal reforms of the 1980s (Le Heron \& Roche, 1999). As a result, there has been an important national shift towards dairy farming which generates higher returns. Over a two decade period dairy has significantly increased its share of total exports, and dairy supply has consistently grown (Macfie, 2010). By 2011, 71\% of Aotearoa New Zealand's export revenues were from primary industry production, and approximately $42 \%$ of this came from dairy products (Ministry for Primary Industries, 2011). The role of the dairy producers' cooperative Fonterra has been crucial in securing a global market share. Fonterra has 10,500 farmer shareholders, and through a number of subsidiaries, exports to or manufactures products in over 100 countries making it the largest Aotearoa New Zealand owned company. Responding to changing market forces, the agri-food industry has sought to unlock freshwater resources to supply irrigation for increasingly industrialised and intensive dairy operations (Barnett \& Pauling, 2005). In Canterbury there has been enormous growth in agricultural irrigation since the late 1980s. For instance, in the Rakaia Selwyn area south of Christchurch, the total allocated water take has grown from under $25,000,000 \mathrm{~m}^{3}$ in $1988-9$ to $237,000,000 \mathrm{~m}^{3}$ in 2010 (Sargent, 2010). In the past 20 years more than 8,000 consents to draw water from streams, rivers and aquifers have been issued by the regional council and Canterbury now has approximately 


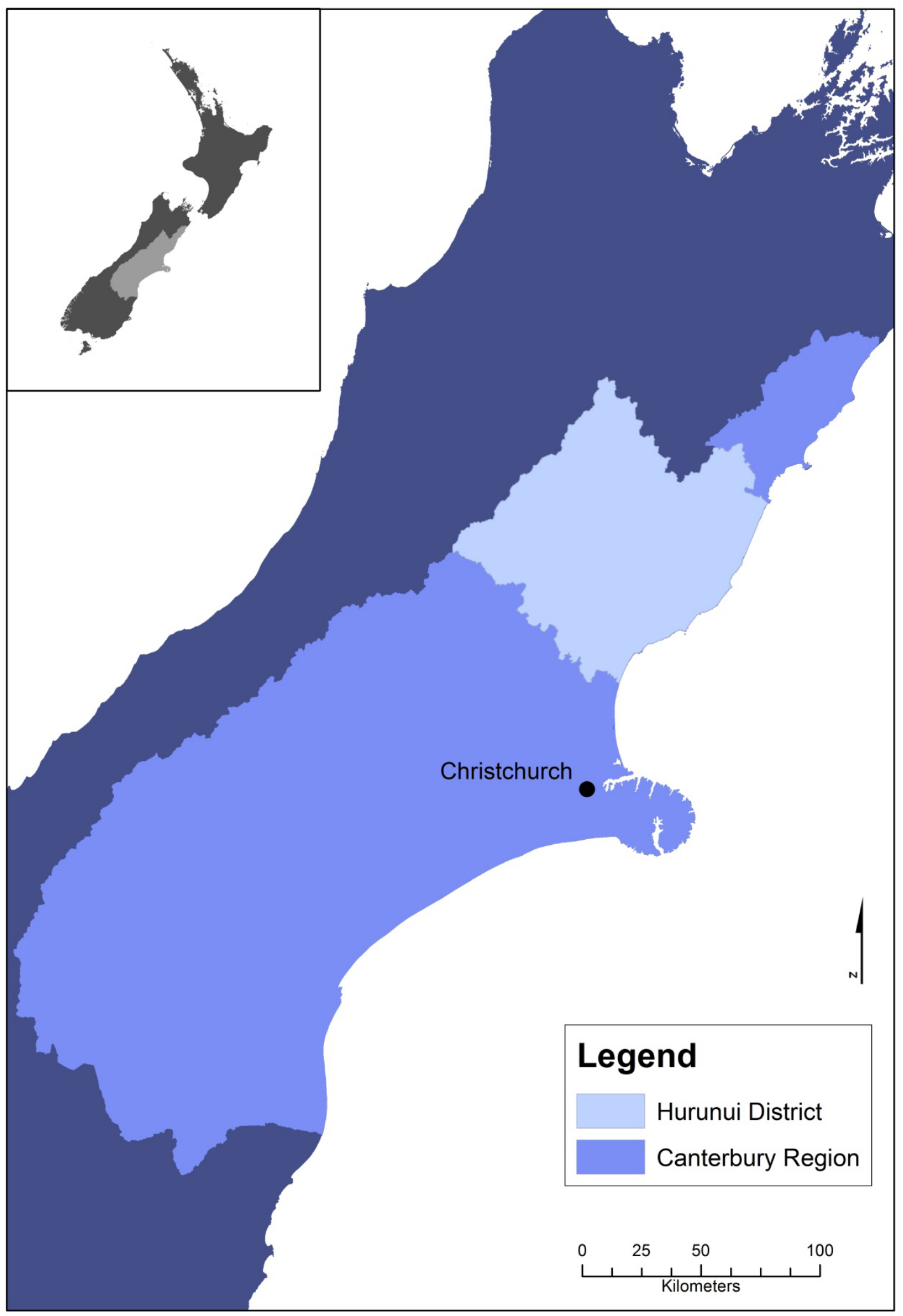

Figure 1 The Canterbury Region and Hurunui District territorial boundaries 
70\% of Aotearoa New Zealand's total irrigated land (White, 2010; Williams, 2010). Facilitated by this water allocation, Canterbury has experienced the fastest rate of conversion to dairy in recent years, an industry credited as the 'golden goose' that saved Aotearoa New Zealand from the worst of the global financial crisis in 2007-8 (Macfie, 2010, p. 18).

However, this conversion has come at a significant cost to freshwater quality and availability. The desire to capture water resources for farm based industries has meant there has been a proliferation of large scale water storage proposals in Canterbury, storage that would see freshwater held back from rivers and either contained in dams, or diverted through extensive networks of canals. Many people are concerned for the health of rivers in the region, and raise questions about what enclosure will mean for river recreation and customary practices. In addition, increasing numbers of cows farmed more intensively leads to greater animal waste and nutrients that can't always be taken up through grass growth (Dymond et al., 2013). Instead nitrogen and phosphorous leaches into waterways through Canterbury's stony and porous soils. Excess nitrogen in waterways depletes oxygen and effectively suffocates most aquatic life forms, and too many nutrients can lead to the growth of periphyton, nuisance organisms that can become toxic to animals and people. Recent research has illustrated that as Canterbury's dairy cattle population has grown exponentially, so has nitrate leaching (Dymond et al., 2013) and, along with animal waste directly entering rivers, has contributed to worsening water quality. A recent national assessment of water bodies found that just $20 \%$ of rivers were safe for people to swim in (Ministry for the Environment, 2013c). Canterbury has also seen rapid nitrate contamination of groundwater, used by many communities for their drinking water supply (McCrone, 2011; Young, 2013).

Ecosystems are changing at the most rapid rate since European colonisation; $35 \%$ of native freshwater fish are now threatened (Browning, 2011). This is particularly problematic for a country whose national identity is so intimately tied to imaginations of environmental purity and uniqueness. Unlike earlier efforts to banish indigenous flora during land clearances, native flora and fauna are now vitally important to Aotearoa New Zealand's unique eco-nationalism (Ginn, 2008). This identity has been amplified and perpetuated through international tourism marketing strategies that promise a country that is " $100 \%$ pure". The meaning of this slogan has been increasingly questioned, leading 
to debates that are not just about the quality of our waterways and ecosystems, but what it means to be an Aotearoa New Zealander within nature (see BBC Hardtalk, 2011; Stewart, 2012).

There have been a number of attempts to address the increasing pressure on freshwater supply and quality. In 2008, the Land and Water Forum (LAWF) was created by a range of interest groups and institutions, seeking to improve land use practices. The forum brought together a broad array of people from 60 different organisations, companies, research institutes and iwi to work together to develop agreement about freshwater management. These parties worked collaboratively to explore and understand different ways of valuing freshwater. The year after it formed, the forum was asked by the government to collaborate and reach consensus on recommendations for water policy. One recommendation the Forum made was that the government adopt a draft National Policy Statement ${ }^{6}$ on freshwater written by an earlier Board of Inquiry, and do so quickly and with only minor changes to the existing draft (Land and Water Forum, 2010). Under the main piece of environmental legislation in Aotearoa New Zealand, the Resource Management Act 1991 (see Chapter 3), regional authorities must have regard to and amend proposed planning policies according to National Policy Statements. However, the freshwater policy statement released in 2011 had significant differences to the earlier draft; references to regulating land use intensification had been removed and water allocation guidelines were changed (Green Party, 2011). Some of the Land and Water Forum members were left questioning the purpose of a collaborative and consensus based process if the government was going to disregard their recommendations (IrrigationNZ, 2012). Furthermore, the policy statement was severely criticised, with one researcher stating that it is very unlikely that it will do anything to arrest the decline in freshwater health in the near future (Sinner, 2011). In addition, contained in the policy statement were the foundations of a new, contestable fund to hasten the progress of irrigation schemes.

\footnotetext{
${ }^{6}$ Under the Resource Management Act 1991, National Policy Statements are a tool for guiding and directing local and regional decision making about environmental issues. To date, only four have been issued, covering electricity transmission, renewable energy generation, coastal policy and freshwater. The reluctance to create National Policy Statements is indicative of a preference for devolved environmental governance.
} 
Since the release of their first report, the LAWF has released two more reports that make recommendations to improve water quality and decision making. Building on these reports, in March 2013 the government released a discussion document entitled 'Freshwater reform 2013 and beyond' that advocates changed formal democracy through greater emphasis on community level collaboration, and limited appeal rights for decisions reached through collaboration (Ministry for the Environment, 2013a). The document also recognises the need for greater recognition of iwi and their role in freshwater decision making. Proposed reforms are still being considered, yet in the interim the government and many industries have continued to support further water storage for irrigation, despite the costs of both water enclosure and dairy intensification to habitats, soil, national branding, river health and freshwater access. One recently approved development in Canterbury, the Central Plains Water scheme, will be one of the South Island's largest ever construction projects, with project managers promising that increased farm profits will trickle down through the region, and the country (Central Plains Water Limited, 2013).

Tensions about freshwater have grown and in 2010 competing understandings of what freshwater is and its relationship with society led the Mayor of Christchurch to describe the state of affairs in Canterbury as one in which the '[c]onservationists vilify the farmers, urbanites hate the cows, farmers resent the townies, and communities divide over what to do' (Parker, 2010). It was in this context of competition between nature/society discourses that central government passed the ECan Act, and devolved and collaborative governance was rolled out in the Hurunui District.

\subsubsection{The Hurunui River}

The Hurunui River, snow-fed and variable, winds down from the Southern Alps and flows out to the Pacific Ocean (see Figure 2 and Figure 3). It's a braided river; as the river transports gravel and sediment down from the mountains multiple different and overlapping river channels are created. The river has been and continues to be a key cultural, economic, historic and spiritual site for Māori; settlements were dotted along the length of the river, and the mouth is the site of wāhi tapu (sacred and immensely important places) (New Zealand Parliament, 1998). As Europeans began to settle in Aotearoa New Zealand in earnest in the mid-1800s, the Hurunui was used as a "highway" 


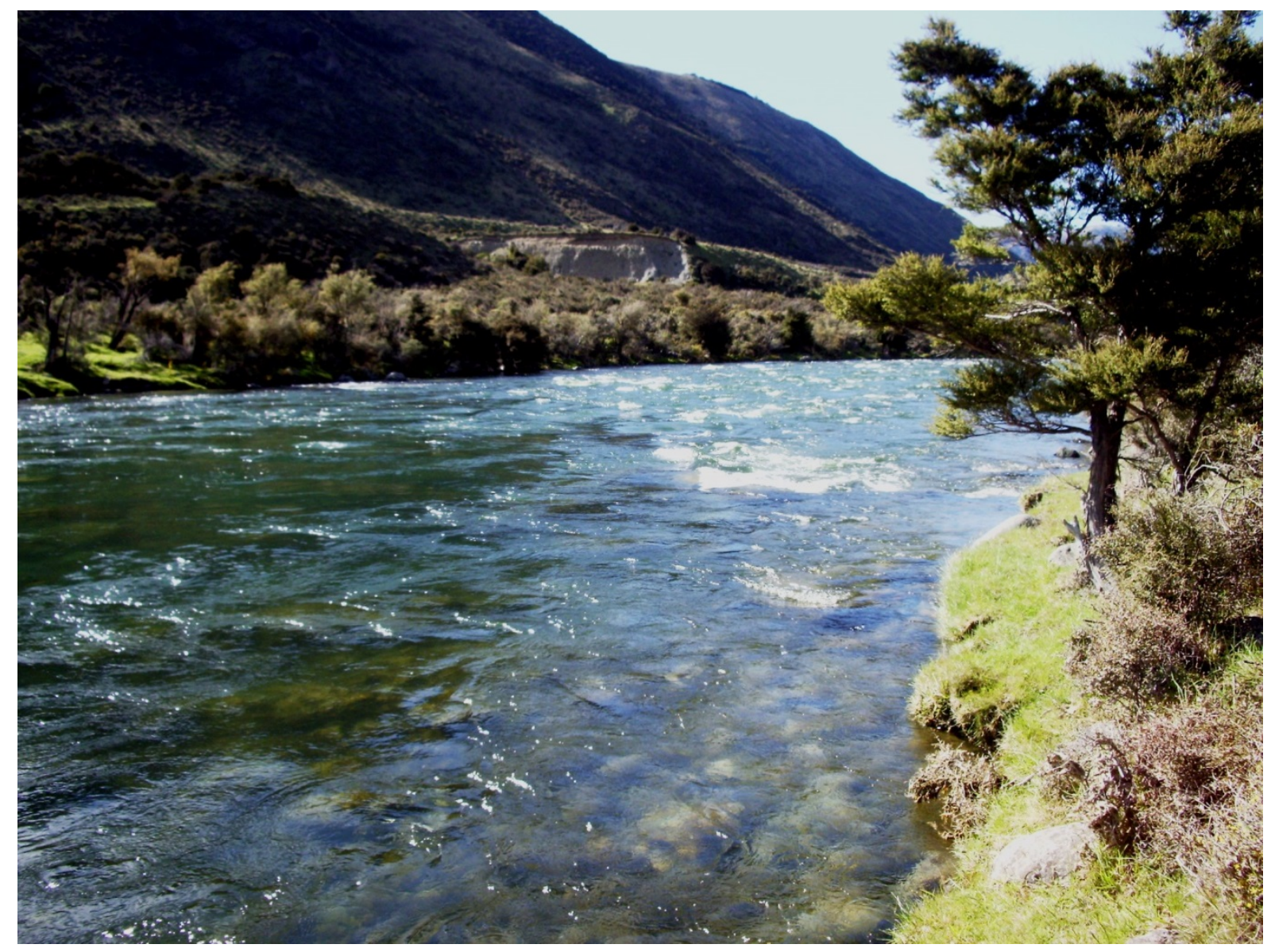

Figure 2 The Hurunui River below Lake Sumner in late spring (Source: Amanda Thomas, 2011).

for miners travelling between the East and West coasts. The crossing was difficult and alternative routes were soon developed. The upper reaches became the sole preserve of a few farming families, and later areas were designated as a forest park to be managed by the Department of Conservation (McRae, 1993).

During the early 1980s, at a time when Aotearoa New Zealand's national government invested heavily in dam projects (as described earlier in this section), attention turned to the Hurunui River as a potential site for hydro electricity generation. These plans were resisted and never came to fruition, and the Hurunui remained free flowing. However, twenty years later, the river was back in focus, this time as a source of water for irrigation. The Hurunui District had been hit hard by drought in the late 1990s, placing significant stress on ecosystems, farming operations and communities. As a result, a group of farmers 


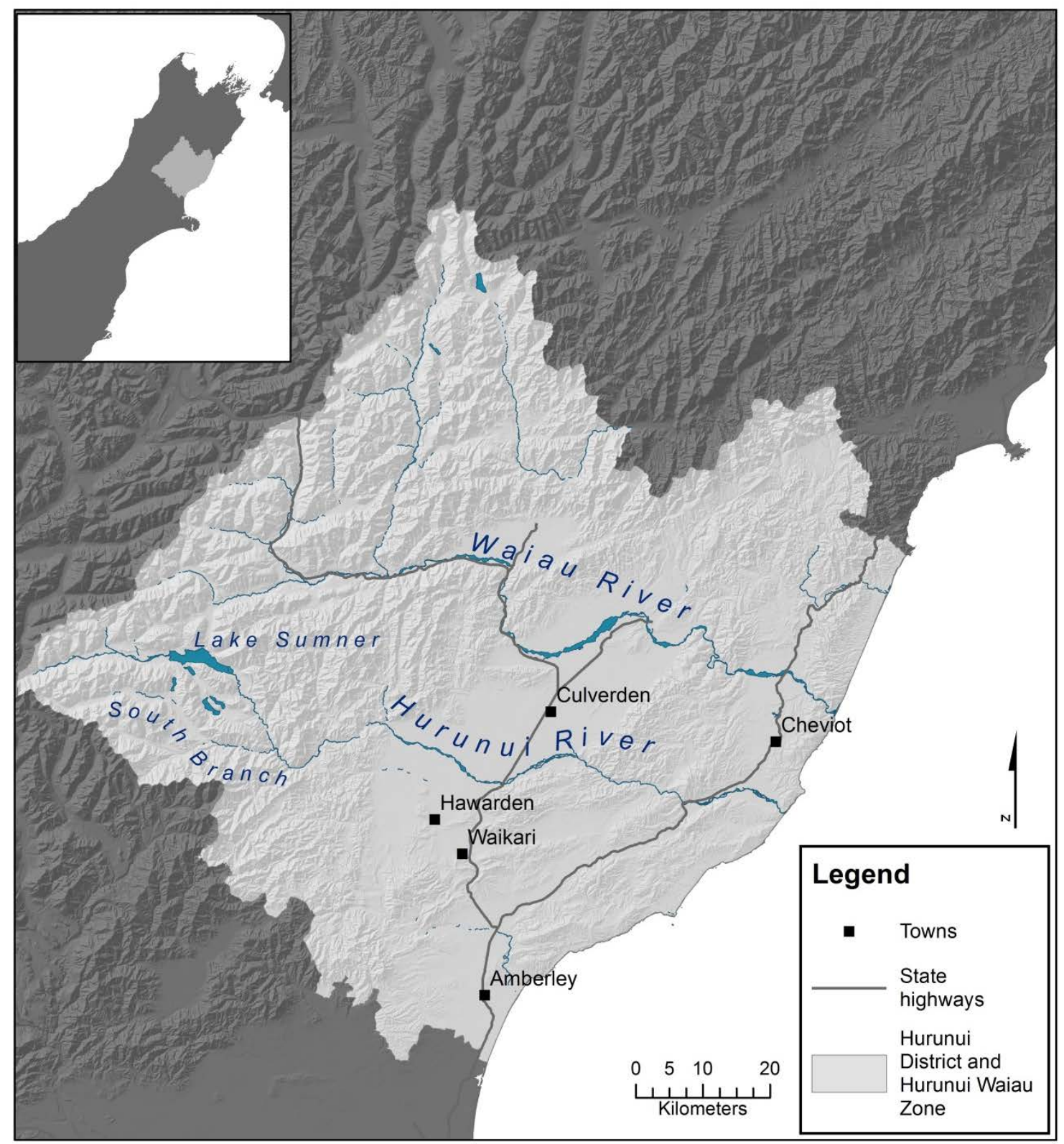

Figure 3 The Hurunui District with towns and large rivers

formed a trust in 2002 in an endeavour to create greater reliability in their access to water, and improve their resilience to future droughts, which are predicted to increase as the climate changes. In order to progress water storage, these farmers joined with Mainpower (a North Canterbury electricity distributer), the person who owned the land around the South Branch of the river, and the commercial arm of Ngāi Tahu ${ }^{7}$ as

\footnotetext{
${ }^{7}$ Ngāi Tahu consists of 18 rūnanga, or grassroots authorities, as well as a corporate arm that includes a property division (see Chapter 6).
} 
shareholders in the Hurunui Community Water Development Project, later renamed the Hurunui Water Project Limited (HWP). Plans focused on placing a dam over the South Branch of the mainstem, ${ }^{8}$ and a weir on the outlet of Lake Sumner on the North Branch (see Figure 3).

The water stored in these two reservoirs would enable the irrigation of over 40,000 hectares, or almost $5 \%$ of the District. In addition to greater reliability, one survey found that over $40 \%$ of those who would have access to this water planned to convert their land from existing uses to dairying or dairy support (cattle rearing and grazing) (Saunders, 2009). Proponents of the storage scheme promised an extra $\$ 200$ million towards the GDP each year and thousands of extra jobs for the District (Loeffen, 2009). For the chairman of HWP it was 'ridiculous' to have fertile land next to a river and not use the water for irrigation. He stated that the Hurunui is:

a river - and there's lots of rivers around, aren't there? If the people of New Zealand don't mind having a second-rate standard of living or if they don't want economic progress, then okay. But New Zealand owes money all around the world ... And if it's not farming that's going to pay that back, I don't know what is (quoted in White, 2010, p. 59).

However, the plans for a dam and weir were deeply contested. Many people rejected the logics underpinning water storage, reliance on the agriculture industry and the importance placed on economic growth. For instance, the North Canterbury chairman of Fish and Game, a hunting and fishing non-governmental organisation that also carries out environmental advocacy, listed the names of many of Canterbury's rivers and stated:

In the course of my life, apart from a few exceptions, all of these rivers have been taken away from people that want to fish or use them for recreation, because of development. And for what? A decreasing position among OECD countries for GDP? Why have we done it? (quoted in White, 2010, p. 62).

Along with kayaking organisations, Fish and Game led the formal opposition to the HWP's scheme. In 2007 these groups, supported by the broad Ngāi Tahu structure, applied for a

\footnotetext{
${ }^{8}$ Throughout this thesis the "mainstem" refers to both North and South Branches of the Hurunui River, and the river body below their confluence.
} 
Water Conservation Order (WCO) to be placed over the Hurunui River. These parties argued that the river had intrinsic value that needed to be protected from large scale dam development. Over a period of two and half years the application was investigated and public hearings held. It was as the process was drawing to a close in early 2010 that central government passed the ECan legislation (see Table 2 for a timeline of key events and processes). Unexpectedly, as well as firing the regional councillors, the legislation also included a number of provisions relating directly to the Hurunui protection order application (Joseph, 2010). The provisions reformed Water Conservation Orders in the region, and acted retrospectively to render the Hurunui process irrelevant, undermining the years of work that had occurred to that point.

Within this tense context, the Hurunui District became the site of the first devolved, catchment based committee established under the Canterbury Water Management Strategy. The CWMS was the result of the drought in the late 1990s and subsequent desires for more water storage. Over time it had evolved to become more inclusive, yet it remained rooted in ambitions to secure "more water" for irrigation (Lomax et al., 2010). The Hurunui Waiau Zone Committee (HWZC), made up of local and regional government appointees, representatives of two rūnanga (Te Ngāi Tūāhuriri Rūnanga and Te Rūnanga o Kaikōura), and appointed community members, met publicly for the first time in July 2010. The Committee was tasked with making recommendations about the future of the Hurunui River for the following 30 years. It was also the first of ten catchment committees to navigate the uncertain post-ECan Act regulatory framework in Canterbury. Over the twenty months following their first meeting, I attended HWZC meetings, interviewed Committee members, and members of the public, in order to explore how different understandings of the relationship between nature and society competed in the conflict over the Hurunui River.

\subsubsection{Research questions}

This research is guided by a central, and several supplementary, questions:

How do different understandings of the relationship between nature and society compete in the new water management regime in the Hurunui catchment? 
a) What are the implications of environmental reregulation in Canterbury for access to decision making about freshwater?

b) How have consensus and collaborative decision making processes affected the nature of democracy and conflict in the Hurunui?

c) How do power relations affect access to public debate about the future of the Hurunui River?

d) How are dominant understandings of nature/society relationships contested?

The remainder of this chapter will provide an introductory explanation of political ecology, the theoretical framework that I have adopted to explore these research questions, and also indicate the contributions this thesis makes.

\subsection{Theoretical framework - diverse political ecologies}

Political ecology is a field of study that is centrally concerned with the complex relationships of nature and society, issues of access and control (Watts \& Peet, 2004) and struggles over environmental 'knowledge, power and practice' (Robbins, 2004, p. 7). It is an approach that holds the potential for both "hatchet and seed", offering critique and generative reimaginations of nature/society relationships (Robbins, 2012). Core themes within the framework include degradation and marginalisation, conservation and control, environmental identities and social movements, and environmental conflict (Robbins, 2004). It has become the foremost approach in geography and anthropology for exploring relationships with nature (Bakker \& Bridge, 2006; Biersack \& Greenberg, 2006; Neumann, 2009).

The roots of political ecology lie in political economy analyses of the ways nature and labour are enrolled into producing value in capitalist systems (Robbins, 2012). In the 1970s such political economy orientations were part of the radicalisation of geography, a time during which positivist approaches to understanding the environment were intensely critiqued. A number of environmental scientists and anthropologists rejected simplistic explanations of environmental degradation as simply poor management or cultural ignorance. For them, the positivist approaches dominating geography could not adequately address the complexity of the causes of environmental problems. Žižek (2008) claims that over time positivist science has replaced religion as the location of truth. In 
many ways, science has been a 'radically liberating' way of learning about the world (Penley et al 1990 p. 9) and it has made incredibly significant contributions to improving society (Forsyth, 2003; Walker, 2003; Willems Braun, 1997). However, positivist approaches neglect that scientific knowledge, like all knowledge, is not free from relations of power, or from language and culture (Budds, 2009; Walker, 2007). Positivist science is one form of knowledge amongst many. Furthermore, the privilege it enjoys as the source of "truth", particularly within resource management approaches favoured by national and global institutions, has not always been positive for the biophysical world or people (Robbins \& Luginbuhl, 2007). Early political ecologists were critical of science based on overly simplistic cause and effect assessments of environmental problems that ignored the social factors that contributed to degradation (Simon, 2008). Theorists often found themselves ill-equipped to examine the effects of colonialisms and market economics on the biophysical world (Walker, 2005). They, therefore, increasingly drew upon peasant studies and Marxist theory to explore the ways that broad processes and pressures produced environmental problems (Peet et al., 2011). In 1987, Blaikie and Brookfield drew this work together into their seminal text, Land Degradation and Society, which focused explicitly on the figure of the land manager. They asked how political, economic and historical processes shaped management decisions and therefore the land. Blaikie and Brookfield, and others, brought attention to the complexity of environmental problems, and the complicated relations that produce them.

Into this space, which was largely focused on rural, male land managers in the majority world (Watts \& Peet, 2004), new strands of political ecology soon emerged as the cultural turn shaped geography. This turn in the early 1990s involved a further shift away from positivist epistemologies and towards explorations of how meaning is made, and particularly focused on nuanced interrogations of power (Castree, 2011a). Political ecologists explored gender, community level decision making, and resistance to and contestation of dominant approaches to natures (Peluso, 1992; Rocheleau et al., 1996b). Particularly influential was a series of texts by key theorists that emerged in the 1970s, 1980s and early 1990s. These theorists, particularly Jacques Derrida, Michel Foucault and Judith Butler, were later identified as poststructuralists, and attributed with developing an approach that examines the links between knowledge and power, and how "truths" are made. To explore these links, poststructuralists have focused on discourse - the 'specific ensemble of ideas, concepts, and categorizations that are produced and reproduced, and 
transformed in a particular set of practices and through which meaning is given to physical and social realities' (Hajer, 1995, p. 44). Meaning is constructed and is contingent, situated within certain contexts. There is, therefore, no "true" meaning outside of language and culture. Furthermore, discourses are always unstable as the 'creation of meaning is an unfinished process, a site of (political) struggle where alternative meanings are generated and only temporarily fixed' (Gibson-Graham, 2000, p. 96). The naturalness and normalcy of certain discourses is created and reinforced through the constitutive outside, the "other" against which meaning is defined (Butler, 1990). The things that are excluded by discourses, however, are always present. Derrida describes "hauntologies", the idea that 'all things that appear as 'being' or as 'being natural' - are haunted, and potentially disrupted, by that which has been excluded' (Braun \& Wainwright, 2001, p. 57).

In detailing how discourses produce effects, Butler (1990) describes performativity - the way that discourses are practised and enacted over and over in ways that produce what they name. She argues that meaning is formed through repeated performance. Writing specifically about identity formation, Butler (1990) states that people make themselves intelligible to others by acting according to norms. ${ }^{9}$ Hence discourses take the form of internal regulations that enable and constrain certain behaviours (Hajer, 1995), meaning that 'what is performed always operates in relation to what cannot be performed or said ... mediated by the unconscious' (Pratt, 2009a, p. 527). Constraints on behaviour include who can participate in discourses and ask certain questions, what questions are relevant and comprehensible within the discourse, and how a discursive order is maintained (Barnes \& Duncan, 1992). However, human agency is always possible because people are subject to competing discourses and the gaps between them, and the "haunting" presences can create disjuncture and spaces for change. Furthermore, the very idea of performativity (rather than fixed identity) highlights a degree of instability whereby processes can disrupt and alter performances (Pratt, 2009b).

The ability to produce change is also inherently linked to ideas of power - what it is, and how and where it's located. Approaches drawing particularly on Marxist traditions understand power as something that is held, and something to be taken (Ekers \& Loftus, 2008). This is often a hierarchical version of power whereby power is enacted in a top

\footnotetext{
${ }^{9}$ Butler uses the example of "doing" hetero or homo sexuality to illustrate her argument.
} 
down manner, or flows outwards from a central point (Allen, 2004). In contrast, a deeply poststructural conceptualisation sees power as dispersed and diffuse, existing through discourses and everyday practices. It is everywhere to the point that it seems to be nowhere (Klein, 2001). Allen (2004, p. 24) critiques both versions for articulating a power that 'leaves little space for political manoeuvre' in the face of a powerful centre or all pervasive everywhere-power. He reconceptualises power as something that cannot be held, but rather as something that circulates and rests at different networked points at different times. It is mediated through time and space and is experienced differently in different places (Cahill, 2008). Throughout this thesis my understanding of power follows that of Allen (2004) - power is ever-present, concentrating unevenly, but not held in a fixed way. This understanding of power enables a more inclusive theorisation of how existing discourses are empowered, and new discourses emerge. In the case of Canterbury, particular nature discourses are increasingly empowered over others; in particular reregulation has supported the dominance of neoliberalised understandings of nature, part of broader ambitions for increased economic growth through agricultural irrigation. This thesis will examine how this dominance shapes access to freshwater bodies such as the Hurunui River.

Poststructuralism was deeply influential for many political ecologists seeking to understand how meanings of nature are constructed and performed, as well as how they are contested and changed (Braun \& Wainwright, 2001; Watts \& Peet, 2004). In particular, political ecologists have sought to understand nature/society discourses that are underpinned by binaries, the understanding that people and the biophysical world are ontologically separate. This ontology has roots in the rise of rationality, a "frame of mind" based on the figure of the logical human, who possesses intentionality and agency (Anderson, 1995). The rational human is cast in opposition to a separate nature, characterised by irrationality and no capacity for agency. It is also a hierarchical ontology by virtue of human capacity for logic, humans are superior to nonhumans. These binaried ways of thinking have also structured gender and race relations - women and people of colour were and are constructed as irrational, ruled by the body, and therefore essentialised as closer to nature (Plumwood, 1992). From the $15^{\text {th }}$ century, 'the reason/nature dualism came progressively to imply a hierarchy that pitted nature both against and beneath human who was henceforth justified in treating nature as object, as background to - and instrument of - human purposes' (Anderson, 1995, p. 277, emphasis 
in original). These gendered nature/society discourses have normalised and embedded relations of domination and subordination, and manifested into a Eurocentric, or western, 'way of being' in the world that pervades many contexts (Anderson, 1995, p. 279). Natures continue to be viewed as collections of objects, tools and resources that lack intelligence and agency. This subordinate range of objects can then be understood as 'resources to be developed or conserved to fuel scientific and capitalistic processes' (Suchet, 2002, p. 147). It is capitalist ways of knowing nature to which I now turn.

\subsubsection{Binaried, hierarchical natures}

Within a dominant, western way of seeing and being within the world, the logic of capitalism has developed its own 'socio-natural metabolism', the unique way in which the biophysical world is 'appropriated, made and remade' (Prudham, 2009, p. 128) and is constantly remade as ontologically separate from humans. The production of a certain nature has always been part of capitalist design (Smith, 2006a); its externalisation and separation from humans has been crucial to capitalist projects as it has enabled accumulation by dispossession, the enclosure of common spaces, which further perpetuates these binaried understandings. Nature is "over there", a series of commodified objects owned and controlled by elites (Harvey, 2003). A nature that is ontologically separate from humans has also enabled the profit driven degradation of environments (Smith, 2006b, p. xii). Within capitalist systems, natures are valued for providing the raw materials for production, fuelling industrialisation. Furthermore, natures are increasingly framed as commodities to be financially valued and marketed, for instance, through the allocation and trading of water rights (Smith, 2006a). In Canterbury, and nationally, discourses about a separate nature that can and should be enclosed are pervasive. Free flowing rivers are often portrayed as wasting water that "just flows out to sea" when that water could be enclosed and used for economic gain (Dearnaley, 2001; Radio New Zealand, 2010).

In the past three decades neoliberalisms have become the dominant form of capitalism, and are based on particular logics of the reworked state, increased market control, extended private property rights and rescaled governance arrangements. While a neoliberal ideology, developed by Hayek and Friedman, can be identified, the ideology has been adjusted, applied and experienced in very different ways in different contexts. 
Theorists, therefore, describe neoliberalisms in the plural, rather than a monolithic and unified neoliberalism (England \& Ward, 2007; Larner, 2003). Furthermore, while neoliberalisms may be dominant, they are often incoherent and unstable (Gibson-Graham, 2006). Given the diversity of neoliberalisms, there is a large body of literature exploring neoliberalising processes and natures (see Chapter 3; Bakker, 2003, 2005, 2010; Harris, 2009; Kaika, 2006; Mansfield, 2004).

Through colonial relations, capitalist and neoliberal binaried and hierarchical worldviews have been extended to Indigenous "others". In the key (post)colonial text, Orientalism, Edward Said (1979) describes how western discourses divided the world into East and West, or Orient and Occident. These discourses represent the Orient and Occident in particular ways that work to operationalise colonial power, and justify colonial practices and capitalist expansion. In particular, Indigenous people in colonised countries have been fixed in time as "uncivilised" and therefore outside of society, yet also having no place in true nature, or wilderness. These representations of Indigenous peoples have facilitated political, economic and cultural processes of alienation rendering Indigenous bodies absent from contemporary landscapes (Baldwin et al., 2011; Coombes, 2007a; Johnson \& Murton, 2007; Muir et al., 2010; Watson \& Huntington, 2008). For instance, Willems Braun (1997) illustrates how the excavation of people from British Columbian nature through colonial power relations allowed the appropriation of this nature by the nation and by capitalism. As demonstrated above, in Aotearoa New Zealand it was seen to be vital to the state and state economy that (largely Pākehā) private property rights were secured, something that was achieved in the South Island by dispossessing Ngāi Tahu of land and ignoring repeated demands for recognition of colonial injustice for more than a hundred years. Uneven colonial power relationships continue to shape much environmental decision making in Aotearoa New Zealand (see Chapter 6), as complex relations work, with varying degrees of success, to render Māori invisible within both economic development and preservationist (or wilderness) paradigms that typically dominate nature politics in (post)colonial settings (Coombes, 2007b).

In contrast to hierarchical binaries between civilised/uncivilised people, and society/nature, and understandings of nature as a fixed, knowable object of study, political ecologists have argued that the meaning of "nature" is socially constructed according to culture and politics (Robbins, 2012). Eurocentric binaries represent just one 
way of knowing and understanding what nature is. A focus on understandings of the relationship between nature and society demonstrates that nature is 'inescapably social ... defined, delimited, and even physically reconstituted by different societies, often in order to serve specific, and usually dominant, social interests' (Castree, 2001, p. 3, emphasis in original). This is not to deny the materiality of natures, the very real physicality of environments, and their ability to make a difference and produce effects (Castree, 2003). Rather, societies and natures are inherently and deeply interconnected. Throughout this thesis terms such as "nature", the "environment" and the "biophysical world" are used interchangeably to describe nonhuman things that are understood in socially and historically specific ways. These things are never entirely "non" human, but dualisms can be difficult to escape in writing (Castree, 2003).

\subsubsection{Destabilising binaries}

Destabilising the dominance of binaried, hierarchical nature/society discourses, and thinking about how more ethical worldly engagements might take form, is a task that has been taken up by a range of theorists. For instance, Haraway (1985), drawing on feminist science studies, describes cyborgs - some part machine, some part human - to illustrate that the boundaries between nature and society aren't ontological, but ideological. She later used the figure of the companion species to disturb nature/society dualisms and argue for a political project that moves beyond binaried, technocratic, hierarchical understandings (Haraway, 2008). A number of geographers have also explored emotions and affect to challenge rational/emotional, mind/body, nature/society binaries. Anderson (1995) has described how the range of human emotions elicited by interactions with nonhuman nature, in this instance the display of animals in a zoo, presents a constant challenge to the dominance of reason and rationality that cannot be easily contained. Martinez-Alier et al. (2010) highlight how the externalisation of nature ignores other ways of valuing the world we are part of, such as spirituality, affect or emotional attachment, and the specificity of different natures (for instance, not all forests are the same, interacted with or valued in the same ways) (Young \& Keil, 2005). Traditions of feminist political ecology have sought to understand these varied experiences of nature through a particular focus on everyday life, and how informal political spaces are linked to processes at other scales (Elmhirst, 2011; Rocheleau et al., 1996b). Feminist political ecologists have explored how relations of gender, ethnicity, and class shape access to nature (Sultana, 
2011; Truelove, 2011). As Mansfield (2009, p. 43) argues, it 'is not enough to note there is a connection between humans and the environment, but one must carefully identify links among multiple, intersecting human-environment interactions'. Understanding the ways that meaning is given to nature, and how this intersects with relations of class, gender, and ethnicity, is important because of the very real impacts those meanings have on human behaviour and interactions with the biophysical world. For Jones $(2009$, p. 296) western nature/society discourses have 'failed us in certain key ways, not least in terms of environmental security and how we live with what has been termed nature and how we understand ourselves'.

Drawing on the work of these theorists, this thesis aims to destabilise the dominance of binaried and hierarchical understandings of nature. As described above, in Aotearoa New Zealand, understandings of freshwater as a tool for economic growth have resulted in the degradation of ecosystems, and threaten human wellbeing as drinking water quality deteriorates and sites of cultural practice and recreation are enclosed. Binaried, Eurocentric nature/society discourses don't adequately account for the multiple values ascribed to and performed by natures. Challenging this dominance is one dimension of my activist-scholar orientation (see Chapter 2). For me, this means making visible and challenging the uneven power relations that produce both social and environmental injustice (Castree et al., 2010; Maxey, 1999). Throughout, I question the assumptions that are implicit in dominant approaches to nature and seek to do some of the intellectual work required to create spaces of democratic plurality.

Despite critiques that political ecology is now a disparate, and at times incoherent, framework (Blaikie, 2008; Watts \& Peet, 2004), the influence of multiple approaches mean that the framework is a nuanced and generative exploratory tool. This thesis is situated within the diversity of political ecology - at various points throughout I draw explicitly on post-structuralism to understand power and how it moves, and is expressed, and the influence of different discourses; (post)colonial theory to examine persistent colonial relations particularly within environmental decision making; and feminist political ecologies to explore how access to the environment is experienced unevenly. These approaches inform the methods I used to investigate different understandings of the relationship between nature and society. Rather than seeking to uncover objective truths, I undertook research from a poststructural feminist orientation to explore how meaning 
was made and remade, as well as being attentive to my own role as a co-producer of knowledge (see Chapter 2). I understand political ecology's diversity as a strength, bringing together multiple theoretical frameworks in complementary ways. In addition, I have sought to further broaden political ecology by drawing on political theory, and explorations of relational ethics.

\subsubsection{Democracy and the "stuff" of politics}

This thesis examines environmental democracy and how democratic formations do or do not create space for multiple nature/society discourses to exist in political spaces. To do this, I explore the work of political theorists and especially radical democratic theorists. Two approaches in particular - communicative planning and radical democratic theory have characterised much contemporary debate about democracy and democratic practices (Bond, 2011b). Communicative planning theory, deeply influenced by the work of Jürgen Habermas (1984), seeks to create the conditions for rational dialogue and to neutralise power relations in order that people might work together for the common good. Deliberation is essential; as Benhabib (1996a, p. 71) states 'no single individual can possess all the information deemed relevant to a certain decision affecting all'. Therefore, through information sharing and deliberation, mutual understanding and learning can be built that has the potential to be transformative for people and conflictual situations. Communicative planning is very influential in contemporary western governance arrangements (Bond, 2011b).

However, communicative democrats have been critiqued for understanding power relations as flat, an understanding of power that is in common with neoliberal discourses (Purcell, 2009). For instance, Young (1996) has argued that although processes might claim to neutralise power the ability to speak and be heard in deliberative processes tends to concentrate with white, middle class, well educated people, particularly men, who offer "rational" (i.e. not emotional) perspectives (also Versteeg \& Hajer, 2010). Instead, radical democratic theory, drawing on the work of Ernesto Laclau and Chantal Mouffe (1985) among others, rejects the possibility that power relations can be neutralised. Furthermore, attempting to do so can perpetuate power inequalities as hegemonies aren't, or aren't adequately, challenged (Purcell, 2009). Rather, power is understood in a poststructural sense as ever present, circulating and concentrating unevenly. The 
theoretical approaches diverge most significantly in the way conflict is treated. Where communicative theorists seek to resolve conflict through rational debate, Mouffe (2000) and others (Purcell, 2009; Swyngedouw, 2010a; Žižek, 1999b) have argued that disagreement and dissent is essential to healthy democracy. Rather than attempting to resolve conflict, importance should be placed on the manner in which conflict takes place. The goal of democracy, Mouffe $(2000,2005)$ argues, should be to change the nature of antagonistic relations so that others are construed not as enemies, but as adversaries that respect the rights of each other to speak and be heard.

Radical democratic theorists have argued that the current political order is increasingly characterised by closure in which spaces and opportunities for dissent are reduced (Mouffe, 2000, 2005; Rancière, 1998). This closure is exacerbated by a progressive erosion of individual rights, described by Agamben (2005) as a state of exception. Swyngedouw (2007) has argued that such a "postpolitical condition" has increasingly characterised environmental politics - environmental futures are limited to the (neoliberal) status quo, and the systems that underpin environmental crises are not able to be questioned or critiqued. As such, spaces for a diversity of nature/society discourses to be articulated and enacted are limited. Given the manner in which the ECan Act suspended individual rights and formal spaces of democracy, radical democratic theory illuminates changing environmental politics. Furthermore, radical democrats bring critical attention to the way devolved democracy risks simply providing a way to obscure the democratic deficits produced by neoliberalisms (Purcell, 2009). Such a focus is important as collaborative, consensus, community based decision making was deployed in Canterbury. This thesis will draw on this branch of theory to explore ways that the new catchment Committee in the Hurunui area did or didn't provide democratic space in which to challenge the dominance of binaried understandings of nature and advocate a diversity of understandings.

The second way that I extend political ecologies and destabilise binaries is to explore what a relational ethics for the nonhuman world might look like, and how it might be brought into political spaces. Braun and Whatmore (2010, p. ix) call for geographers to interrogate the "'stuff" of politics'; they challenge us to imagine a politics that acknowledges that humans are not separable from nature. Two particular branches of theory that have been influential within geography have engaged with this call, although in different ways. More than human theorists have focused on how nonhumans are conceptualised, in particular 
questioning the construction of nonhumans as objects rather than subjects (Sundberg, 2011). These geographers have brought attention to the ways that the biophysical world co-constitutes and therefore deeply shapes the human world (Haraway, 2008; Whatmore, 2002). A wide ranging body of literature has explored the ability of plants, animals, insects and water to affect change (Bear \& Eden, 2011; Beisel, 2010; Head \& Atchison, 2009; Jones, 2011). Situated within understandings of the world as co-constituted by a multitude of things, more than human theorists have sought to imagine and enact new ethical formations for the nonhuman, ethics that are situated within particular relationships (Bennett, 2010; Haraway, 2008). Political ecologists have increasingly engaged with more than human geographies.

Unlike more than human geographers' attempts to imagine and enact new ethical formations, Indigenous geographers have asked how already existing Indigenous ethics for nonhumans are silenced or ignored through (post)colonial power relations (Johnson \& Murton, 2007; Roberts et al., 1995; Rose, 2005). For many Indigenous communities and geographers, the challenge is to break down the dominance of Eurocentric worldviews in environmental decision making (Howitt \& Suchet-Pearson, 2006). In this thesis, I draw more than human and Indigenous geographies into conversation to explore moments of both success and failure in contesting uneven (post)colonial power relations and articulating relational ethics in the HWZC space. Doing so also enables me to examine (post)colonial environmental management in Aotearoa New Zealand, and the opportunities to decolonise more than human geographies, rooted as they are in western settings.

\subsection{Contribution}

This thesis makes a number of contributions to existing literature. Firstly, I add to the small body of political ecology research that explores the intersections of neoliberalisms and nature in Aotearoa New Zealand (Hobson Haggerty, 2007; Memon \& Kirk, 2011). Addressing this gap is important because the nuanced nature of political ecology can illuminate multiple processes and relations that are part of the reregulation, enclosure, privatisation and valuation of the environment (Heynen \& Robbins, 2005). 
Secondly, there is little political ecology literature, particularly case based research, that engages with radical democratic theory (see Celata \& Sanna, 2012; Swyngedouw, 2010a; Swyngedouw, 2013b). Both bodies of literature seek to explore how decisions are made, who is excluded in the process, and to what effect. This project therefore, draws poststructural feminist political ecologies together with radical democratic theory in novel and generative ways. In doing so, I also add nuance to theorisations of post-politics, which have been critiqued for being totalising and overly state-centric (Chatterton et al., 2012; McCarthy, 2013). In working within a feminist poststructural tradition, I explore the multiple scales at which politics and contestation take place, and the labour required to enact post-politicising processes. Such an exploration comes at a critical juncture in environmental politics in Aotearoa New Zealand, as processes that constrain democracy are increasingly brought into focus (see Kedgley, 2013; Salmond, 2013).

Thirdly, I contribute to emergent research exploring everyday experiences of power and how these experiences shape access to nature. In particular, recent political ecologies have explored the effects of power on individuals, and how hegemonic power relations are contested by people (Ekers \& Loftus, 2008; Loftus \& Lumsden, 2008; Peet et al., 2011). To add to this body of literature, I draw particularly on feminist scholarship that examines how informal political spaces in which uneven power is experienced shapes formal political processes (Staeheli et al., 2004). This research comes at a time when communities are often privileged as the superior location of democratic decision making, a privileging that ignores the multi scalar nature of power, and may have damaging effects on processes, outcomes and the people and environments concerned.

Finally, I contribute to efforts within political ecology to challenge hierarchical nature/society binaries by exploring situated, ethical relationships with more than humans. More than human geographies have been increasingly drawn into political ecologies, and yet have been critiqued for privileging Anglo/European knowledges (Panelli, 2010; Sundberg, 2013). To further decolonise more than human geographies I focus on the generative possibilities of engaging with Indigenous cosmologies and geographies that have demonstrated the wealth of already existing relational ethics. These accounts hold vitally important lessons about the challenges and successes of changing political spaces to embrace multiple ways of knowing natures (Coombes, 2007a). They also demonstrate the particular struggles of decision making about the environment 
in (post)colonial settings in which power is networked in deeply unequal ways. Gibbs (2009, p. 361) argues that bringing together Indigenous and more than human geographies can provide the theoretical and conceptual tools to understand the 'complex interactions that form particular places, and comprise a more-than-human world'. Following from Gibbs and others, I bring these bodies into conversation to question how natures might be imagined and enacted differently.

\subsection{Thesis structure}

This thesis will expand upon emerging themes in current political ecology literature, particularly questions about democracy and post-politicising closure, and explorations of relational ethics with more than humans. Literature and research findings are combined in the four chapters that form the body; this reflects the case study driven approach adopted in this research, whereby material and theory are built simultaneously through an iterative, scale crossing process (Glaser \& Strauss, 1967). It also lends clarity to a case study that explores politics at multiple scales, and the way these politics shaped environmental access.

In the following chapter I explain how I have approached this research, charting what it has meant to do research in a feminist poststructuralist way that also works to be decolonising (Howitt \& Stevens, 2010). I describe how I understand myself within knowledge production, as well as my orientation towards activist scholarship. Throughout, I examine the challenges and rewards of adopting an approach to research ethics that goes beyond formal university processes. The chapter describes the way that a mixed methods approach was used to explore how meaning was made in the conflict over the Hurunui River.

Chapter 3 develops important conceptual framings that orientate the rest of the thesis. I begin the chapter by examining theorisations of neoliberalisms, and situate my research within these debates. I then turn to political ecologies that explore the neoliberalisation of natures. Heynen and Robbins' (2005) conceptualisation of four broad relations of neoliberalising nature - governance, enclosure, privatisation, and valuation - are discussed, as well as political ecologies that examine the ways neoliberalisms are contested. Focusing in particular on reregulated governance and attempts to enclose 
nature, I analyse environmental reforms in a neoliberalising Aotearoa New Zealand, and more recent freshwater reregulation through the ECan Act. Chapter 3 will also further explore the implications of the ECan Act for environmental democracy.

Chapter 4 explores the devolved, collaborative democracy that was rolled out in the wake of the ECan Act. I examine the ways catchment level decision making based on consensus and collaboration both illustrated, and contested, processes of closure that limited spaces for public debate about environmental futures. Focusing on the foundations and work of the HWZC, I use radical democratic theory to explore reformulated freshwater governance arrangements while also using the case study to demonstrate the importance of emergent critiques of radical democratic theorisations of post-politics.

In Chapter 5 I explore how spaces for public debate and dissent about the Hurunui River were limited through constructions and performances of community. I chart the ways that belonging to community in the Hurunui District was defined within neoliberal and rural discourses that emphasised spatial membership, good economic performance, and certain behavioural norms, including those based on gender. Throughout this chapter I analyse everyday experiences of power, how these experiences shaped access to public debate about the Hurunui River and what this meant within a management regime that privileges community as a scale of democracy.

Chapter 6 asks how political spaces might include a plurality of nature/society discourses, rather than channelling certain understandings of nature. In doing so I focus in particular on the complementary aspects of Indigenous and more than human geographies, and how both offer promising frameworks for articulating ethical relationships for nonhuman things. This chapter is also deeply situated within (post)colonial critiques of environmental decision making. By examining Ngāi Tahu's role and work within the HWZC, I explore the generative aspects of collaborative practices while highlighting the gaps that remained unaddressed in the Hurunui District.

In the concluding chapter, I reflect on how democratic processes shaped the competition between different understandings of nature, and how the Hurunui conflict is situated within wider contemporary debates about environmental access. I argue that there is significant work to be done to reclaim and hold democratic spaces of dissent, and create political spaces in which multiple worldviews can simultaneously exist. 
32 | Introduction 


\section{Methodologies: the tricky navigations of doing reflexive, responsible and accountable research}

\subsection{Introduction}

Nine months after beginning this research I was settling in to observe another Hurunui Waiau Zone Committee meeting when a Committee member who I liked and respected approached me in a confrontational way, demanding to know if I had taken part in writing a pamphlet titled "Hurunui water matters" that opposed water storage. I knew nothing of the brochure and told him so; he said someone had mentioned my name, but wouldn't say who. He quickly turned away. I felt quite shaken by his manner, and worried about the potential effects of his accusations for my research in a highly contentious political context. He later apologised after I emailed him, an email in which I assured him of my "neutrality" despite a feminist poststructuralist orientation that rejects the possibility that research is ever neutral or objective.

This chapter explains how I conducted this investigation in a way that navigated commitments to doing ethical and accountable research in an often challenging and high stakes, but deeply rewarding, context. Firstly, I explore the contours of feminist poststructuralist understandings of knowledge and claims to truth before turning to an explanation of how I adopted a feminist poststructuralist orientation. This orientation offered a useful approach to examining how people understand nature and how different knowledges compete in decision making. In order to situate knowledge production, feminist geographers have argued for a reflexive approach through which the researcher situates themselves. Being reflexive throughout the research process 'involved reflection on self, process, and representation, and critically examining power relations and politics 
in the research process, and researcher accountability in data collection and interpretation' (Sultana, 2007, p. 376). Following Sultana, I then offer reflections of myself, exploring how my fluid, changing identity influenced the development of this project (Gibson-Graham, 1994), as did the murky boundaries of "the field" (Cupples \& Kindon, 2003). Situated within a reflexive approach, I then discuss research ethics, extending beyond formal university processes to think through a participatory ethic in a politicised context, and the particular ethical considerations that flow from (being Pākehā and) working in solidarity with Māori. The remainder of the chapter reflects on the methods that were used to gather material, adopting a feminist approach to semi-structured interviews and participant observation, and how material was then analysed and "written in" (Mansvelt \& Berg, 2010). Throughout I am concerned with the negotiations required of engaged and responsible feminist research that works to be decolonising, discussing what was more and less successful (England, 1994).

\subsection{Feminist poststructuralism - exploring meaning and destabilising truth}

The work of feminist and poststructural scholars led to a significant turn in geography that has brought to the fore questions of knowledge production and meaning creation. Geography in the 1950s and 1960s was characterised by research that sought to be impartial and objective, and therefore maintained distance between academics and the researched (Kobayashi, 2003; McDowell, 2010). In contrast to these positivist approaches, as described in Chapter 1, poststructuralists and feminist scholars began to challenge the idea of neutral knowledge production in the 1970s. Poststructuralism begins from a rejection of claims to universal truths, fixed categorisations and binaried understandings of the world (Woodward \& Jones, 2009). Theorists such as Foucault, Derrida and Butler have argued that meaning is unstable and changeable, and situated within discourses. Therefore there is no truth to be uncovered and claimed by researchers as "discoveries". Instead researchers are concerned with the ways meanings are made, remade and contested (Hajer, 2005), how claims to truth are made, and the way truths are performed (Butler, 1990). It is an approach that accepts that 'methodologies and forms of knowing will be characterized ... by openness, reflexivity and recursivity' (Davies \& Dwyer, 2007, p. 
258). Informed by poststructuralism, this project recognises that multiple meanings and ways of knowing the world exist and seeks to explore the ways that people make meaning.

Although some feminists have rejected the anti-essentialism of poststructuralism, arguing instead for instance, that there are fundamental differences between men and women, many feminist scholars have shared, and often taken the lead in, the project of highlighting the damage done by claims to universal truths. For instance, feminist science scholar Donna Haraway (1985; Penley et al., 1990) has argued that scientific knowledge is contingent, and has artificially constructed boundaries between human, animal and machine. Also confronting boundaries, Audrey Kobayashi (1994) called for and carried out anti-racist feminist geographies that explore essentialising racial categories. Feminist geographers have been particularly attentive to the politics of knowledge production, initiating and leading debates about the conditions through which research takes place (England, 1994; McDowell, 1992; Rose, 1997). Knowledge, these theorists claim, is always situated and partial - it cannot be separated from the conditions under which it was produced, and the role of other actors, including the more than human, in coproducing it (Haraway, 2008).

Reflections on these conditions, described as reflexivity, seek to understand how relations of power shape research processes and outcomes, and draw particular attention to the role of the researcher in these power relations. Reflexivity contrasts with approaches rooted in masculine traditions which position the researcher as a detached, objective authority (Bondi, 2009). Instead knowledge is coproduced between people participating in the research. The "researched" are therefore commonly framed and understood as participants, reflecting that they are more than objects of study, and the ways they shape investigations. Qualitative research also cannot be separated from social conditions, and is shaped by relations of gender, class, race, age and sexuality. Researchers are prompted to simultaneously 'act and to reflect on their actions' within these relations (Bondi, 2009, p. 329). Furthermore, attempts to redistribute power more evenly between the investigator and participants, and avoid recreating social exclusions, are typically part of reflexive processes (Kitchin \& Tate, 2000).

Kobayashi (2003, p. 348), however, warns that reflexivity may have outlasted its usefulness in working for social change, having 'no meaning if it is not connected to a larger agenda'. She warns that introversion and confessionals should be avoided and room 
made instead for more productive, political writing (and action). Striking a balance between "self-indulgence" (Kobayashi, 2003) and cultivating an engaged, outward looking research practice can be difficult (Bondi, 2009). Indeed, being reflexive about my position doing fieldwork in the Hurunui area is complicated - while I can identify that I am Pākehā, a woman in my mid-20s, middle class, heterosexual, cis-gendered, and educated at a tertiary level, simply acknowledging these labels and ticking them off a checklist doesn't represent an adequate engagement with how knowledge is co-constituted (Rose, 1997). Concepts such as "Pākehā" and "woman" have different meanings in different contexts (Larner, 1995; Simmonds, 2011) - Pākehā is a contested Māori term for a New Zealander of European descent (Jackson, 1998), and performing "appropriately" as a woman is often shaped by different cultural contexts (see Chapter 5). So although Nast (1998) calls for feminist scholars to be attuned to how participants construct and read the embodied researcher, it's impossible to fully know how I am positioned by people, and how categorisations that have shifting meanings will be read by others. Furthermore, I can never be fully cognisant of who I am - my identity is uncertain, unfixed and can't necessarily be uncovered and revealed through reflection (Gibson-Graham, 1994; Rose, 1997). It is performed through everyday life, shifting within changing (and complex) relations of power, relations that I am always subject to and engaged with. What I do know is that when I was doing research with the HWZC, I was often acutely aware of being a young, sometimes awkward, woman amongst people who were mostly older white men. Reflecting Sharp's (2005) claim that the researcher is not necessarily powerful, sometimes I felt isolated, uncomfortable, exposed and defensive because of my own sense that the ground I occupied as an early career academic was uncertain (Bondi, 2007), particularly as I lacked experience in "the field".

\subsubsection{Navigating the co-constituted field}

Like research, I understand "the field" as a co-constituted space with fluid and murky boundaries (Cupples \& Kindon, 2003). It is not something that researchers are entirely inside or outside of (Katz, 1994). This feeling of never being completely inside or outside was made increasingly apparent to me through my family ties to the Hurunui District and the colonial land relations I'm constituted through (Cameron, 2011). My paternal family has lived in the District since the 1850s. Many of them cleared large tracts of land, and are likely to have been the direct benefactors of land purchases from Ngāi Tahu by Crown 
agents in North Canterbury. The purchase of the North Canterbury block was contentious because the Crown breached Te Tiriti o Waitangi principles in a number of ways (Waitangi Tribunal, 1991). Firstly, the Crown exerted undue pressure on Ngāi Tahu to sell land. Secondly, the tribe was never properly compensated and thirdly, the Crown didn't set aside reserves for the iwi, as they had agreed. Within the context of ongoing contestations over land, my paternal grandparents bought from family one of the farms that was secured through colonial land relations, and raised their six children on it. In 1980 my Grandfather died, the farm soon sold, and my Granny moved into nearby Amberley. I was born and raised an hour and half's drive from the District so for me the Hurunui area isn't really "home", although I am tied to it in many ways (Sultana, 2007). Growing up we often visited Granny and holidayed in the area, and my Dad and the rest of his family are still firmly linked into District life.

These family ties shaped my research in many ways - doing fieldwork there drew on and drew together my family and our history. I had made my family links clear when I first introduced myself and my research to the Hurunui Waiau Zone Committee. It turned out that one Committee member had gone to school with my Aunty. Later, my Granny met the Mayor of the District when I interviewed him at her home, and since then the Mayor has often asked my Granny about how I am and about the progress of this project. It's difficult to know how these old and new connections shaped my research, but I did feel like they made establishing contacts easier - rapport was quickly established around these connections that made the relationships feel more comfortable. Connections created common ground across which research participants and I could speak, despite differences in gender, age, class, and ethnicity (Sultana, 2007). I was both an insider and outsider in many ways - Pākehā in a largely white district but a lefty in a right wing conservative party stronghold; linked by family, but living elsewhere; brought up in the country but now a "townie", and worse, a resident of Wellington, the location of so much loathed bureaucracy. These border-blurrings and crossings, which extended beyond spatial demarcations, were sometimes awkward and had to be carefully navigated. For example, a research participant joked during an interview that his sister and niece were members of Greenpeace and vegetarians, would you believe it! I desperately hoped afternoon tea wasn't ham sandwiches, but I was prepared to sacrifice my decade-long vegetarianism if it was! I'm not sure how, or even if, being a vegetarian would have changed the way the 
participant interacted with me, but I didn't want to risk finding out as the interview was going well (see McDowell, 2010).

As I visited the District to attend HWZC meetings and do interviews (see below), I often stayed with my Granny. We talked about the District, water, and the way connections between people shaped so much about rural life. This was the first time I had asked and listened to her talk about her life in the area, and these evenings spent with her added layers and nuance to my understanding of everyday life in, and the histories of, the District. They also meant, along with connections forged through my family history and my interactions with people, that I felt a great deal of responsibility to research participants. I was conscious of the intrusion that my interviews represented (although for some it may have also been an enjoyable experience) and the way that speaking to me has possibly exposed people to risk as they talked about their positions within a highly politicised debate (England, 1994).

This prompted me to think carefully about ethical responsibilities to the co-creators of my research. As the author, I ultimately decided the scope and focus of the study, and how material has been interpreted and communicated. In this sense, and because I have a high level of formal education, and access to the tools that flow from tertiary education (literacy, resourcing and networks), I occupy a privileged position relative to research participants (Rose, 1997). Furthermore, the benefits of doing this research will be disproportionately accrued by me as I receive a qualification that is seen to impart prestige, and may lead to improved employment prospects and mobility (Maxey, 1999). Yet, while this power should be reflected on and destabilised, it also holds productive and creative potential (Gibson-Graham, 1994); the tools named above can be deployed to explore and challenge social injustices, and (importantly) work in solidarity with others (Kobayashi, 2003). Working in a feminist tradition, and therefore freed from positivist requirements for objectivity, I understand myself as an activist-scholar (McDowell, 2010). For me, doing feminist poststructuralist research means adopting a 'clear politics that works against the forces of oppression' (Katz, 1994, p. 67), is centrally concerned with social and environmental justice, and works towards transformation (Kobayashi, 1994). In identifying as an "activist" scholar I draw on feminist traditions that reject the notion of activism as necessarily 'dramatic', physical, 'macho' (Maxey, 1999, p. 200). My understanding of activism is that it is a commitment to carefully considering how I am 
implicated in producing and reproducing the world through everyday life, and working to change things by making visible and challenging injustices (Castree et al., 2010).

Given this orientation, I need to identify here that this thesis is centrally concerned with social and environmental justice in Aotearoa New Zealand (Charmaz, 2011). In particular, I attempt to address the uneven power relations that are linked to certain neoliberal discourses. While recognising that neoliberalisms hybridise with other discourses, and therefore draw together multiple rationalities with varying effects (Larner, 2000b; Lewis, 2009), I am interested in exploring and critically engaging with the uneven effects of neoliberalisms and attempting to transform oppressive relationships through intellectual and political work (Springer, 2012a). Throughout my research I maintain a 'commitment to an ethical ideal' (Aronowitz, quoted in Cahill et al., 2007), an ideal which sees the naturalness of neoliberal discourses interrogated and undermined, and futures imagined that embrace a plurality of worldviews. These commitments, like other aspects of my positionality, are not at the expense of the "trustworthiness" of my research however (Mansvelt \& Berg, 2010). Charting my positionality does not mean that this research wasn't "rigorous" or that it is an incomplete reading of the case study.

The meaning of rigour in qualitative research is contested; in this thesis I adopt Mansvelt and Berg's (2010) ideas of "trustworthiness" that is built through thick description. Accordingly, thick descriptions go to the heart of a case study to explore peoples' experiences in that place, the meanings they make of the world, and the motivations that drive them. Developing trustworthiness also involves demonstrating that from the outset research projects are nested within relevant literature and undertaken for 'intellectually and ethically justifiable reasons' (Bradshaw \& Stratford, 2010). The following section will chart how I worked to establish trustworthiness through a careful and ongoing consideration of ethics, and by adopting mixed methods to gather rich and nuanced information.

\subsubsection{Feminist, (post)colonial and decolonising ethics - tricky negotiations}

All research carried out through Victoria University of Wellington that involves people must have approval from the Human Ethics Committee. In June 2010 I submitted an outline of my research and research methods to the committee and received approval a month later (see Appendix A). At each interview participants were given an information 
form to keep, and asked to sign a consent form. These documents set out the scope of my research, stating my focus on the HWZC and plans to interview Committee members and people interested in the Hurunui River (see Appendix B). They also made it clear that participants could stop the interview at any time, decline to answer any questions, and had a six month period during which they could retract any statements. Doing ethical research is not, however, limited to working through a checklist to gain approval from a committee and attaining informed consent (see Elwood, 2007; Maxey, 1999). Ethical approaches that take seriously the co-constituted nature of research require constant reflection on power relations that shape knowledge production.

As explored above, feminist methodologies recognise the co-constituted nature of research, a recognition that is aligned with participatory methodologies. While there are a range of methods for conducting participatory research, it is centred on collaborating with communities for positive change and involving participants at every state of inquiry (Kindon et al., 2007). A participatory ethic, according to Elwood (2007, p. 331), requires engagements with 'the ways that identities, group membership (or exclusion), and power relations can shape ethical practices and challenges in the social situations of research'. Furthermore, Cahill et al. (2007, p. 306) state that participatory inquiry involves an 'ethical stance against neutrality' and needs to develop and work within respectful relationships. Ways of building respectful relationships include the joint development of research aims by research leaders and participants, collective decisions about methods and outcomes, and dialogue throughout.

From the outset, I have attempted to build respectful relationships through such practices, yet doing so was complicated and at times, fraught. I had initially enrolled to do a Masters' before upgrading to a PhD four months later. Wanting to capture Zone Committee members' feelings and understandings as the HWZC was just beginning its work, I went to their first public meeting two months after I first enrolled. There I introduced myself and my research and invited people to consider participating by being interviewed. To this point, I was the sole designer of the project and the short time frame of a Masters thesis (around 12 months in Aotearoa New Zealand) meant I needed to progress to gathering data quickly. In the following months, as I redesigned aspects of my project to fit with a $\mathrm{PhD}$, I considered ways to enable people involved in Hurunui water politics to shape the project. This was difficult as I already had formal university ethics approval; I had already 
introduced the scope and focus of my research to the HWZC; the HWZC had already begun to meet and were operating on a tight timeframe; and the overall aims of the project were defined even though these were constantly reflected upon and adjusted according to my case study driven approach (see below). In late 2010 and early 2011 I approached the HWZC facilitator who was employed by ECan, and the Mayor of the Hurunui District (also a Zone Committee member), and asked if there was anything that was broadly aligned with my research that they would like investigated further. The Hurunui Mayor expressed interest in and support for my project, but the facilitator was less interested, and neither asked for anything to be included. I repeated the offer to the facilitator, emailing him a more detailed outline of my research, but didn't get a response. At that stage, ECan had been recently reorganised through the ECan Act and was rapidly rolling out the CWMS, and a month after I emailed, a significant earthquake struck Christchurch. The February 2011 event followed from a large earthquake in September of the previous year. Where the September quake had caused significant damage to property, but no loss of life, the February earthquake resulted in the loss of 185 lives and the near complete destruction of parts of the city. Many people working with the Committee, including the facilitator, were severely affected by the events. In this context, I had to be careful not to make my research more of an intrusion that it must have been at times, so I didn't ask for ECan's input into research design again.

Questions about participatory ethics were all the more pressing in a project that attempted to be decolonising. Geography research has been deeply implicated in colonising projects - constructing and objectifying the "other", supporting European expansion, and privileging western science. The relationship between the geography discipline and Indigenous peoples has been the focus of a growing body of work, examining colonial relationships and increasingly placing a central focus on Indigenous worldviews (for a brief overview see Frantz \& Howitt, 2012). Yet this is not a simple separation between a colonial past, and (post)colonial present. Smith (1999, pp. 7-8) argues that '[r]esearch is one of the ways in which the underlying code of imperialism and colonialism is both regulated and realized. It is regulated through the formal rules of individual scholarly disciplines and scientific paradigms, and the institutions that support them'. The imperatives associated with universities - to publish, to produce original work, to attract funding, all within institutions that are increasingly corporatised - can reproduce extractive colonising practices (Kapoor, 2004). 
In response to these pressures and a long history of research on Māori rooted in imperialist thought, recent decades have seen Māori academics and communities develop an assertive, autonomous, Māori-centred paradigm for doing research (Bishop, 1996; Smith, 1999). Extractive research practices have not generated benefits for Māori, don't recognise the legitimacy of Māori worldviews and have perpetuated racist and paternalistic perspectives (Durie, 1996). The emergent paradigm, Kaupapa Māori, asserts a claim to self-determination by Māori and for Māori in an attempt to change colonial power relations (Bishop, 2008). Doing Kaupapa Māori research means Māori culture and ways of being are positioned not as the "other" but as the norm, and thereby seeks to challenge the hegemony of Pākehā knowledges. It is a way of doing research that is relevant to and works to create beneficial outcomes for Māori (Rangahau, n.d.). Cunningham (2000) states that throughout all stages of Kaupapa Māori research Māori exercise control - in identifying the focus, design, who will do the research, and how research will be assessed and measured.

Simultaneous conversations have occurred about what it means to be non-Māori and doing care-filled, responsible and accountable research with Māori (McClean et al., 1997; Stokes, 1987; Tipa et al., 2009). My research, although not Kaupapa Māori, has adopted an approach that seeks to work in solidarity with and for Ngāi Tahu. Howitt and Stevens (2010) describe different types of non-Indigenous research with Indigenous peoples. (Post)colonial approaches value other peoples' 'rights, knowledge, perspectives, concerns and desires and are based on open and more egalitarian relationships' (Howitt \& Stevens, 2010, p. 42). Decolonising research goes further, addressing inequalities in power relationships and societal structures that sustain colonialisms (Howitt \& Stevens, 2010). In this sense my work is deeply (post)colonial, contributing to calls for far greater acknowledgement of multiple ways of knowing nature, particularly Ngāi Tahu's worldviews, and works to be decolonising by interrogating layers of inequality in accessing the environment and democracy. Accordingly, this has involved constant reflection about my own position as a Pākehā and has required careful listening to develop understandings, and a humble approach to knowledge (Coombes et al., 2011; Smith, 1999). I have sought to examine the privileged place of Eurocentric knowledges in environmental decision making, while I also acknowledge that this research has been shaped by western knowledge systems, and requirements and incentives to produce research in a particular way. 
One aspect of my research that has felt uncomfortable in reflection was that the central focus of my research project was already mapped out when I began my fieldwork. As described earlier, I had rapidly moved from enrolment into "the field" as the HWZC held its first meeting, and I wanted to begin interviewing straight away in order to complete what was then an (unfunded) Masters within 12 months. I soon realised that forming the research project myself reinforced my authority and power to some extent (Kindon, 2012), and was not consistent with the (post)colonial and decolonising research I wanted to carry out. Done differently, I would have tried to develop relationships with Ngāi Tahu prior to beginning the research. As a result of reflections on these initial failings, and attempting (successfully and unsuccessfully) to move beyond 'the mental hand-wringing of a straight, white ... feminist academic' (England, 1994, p. 84), I sought to address this deficiency throughout the rest of my work. At an early HWZC meeting, I explained my research to rūnanga representatives on the HWZC, and asked them what they would like explored and how. One of my first interviews was with the original Te Rūnanga o Kaikōura representative, and he responded positively to my efforts to decolonise my research practices (personal communication, 19 August 2010). He didn't identify anything to add to the research scope, but six months later, after he had left the Committee, it became apparent that I would have to make clearer efforts to invite other people from Ngāi Tahu to shape the project. I had become aware of recent events in the Hurunui District that had seen contention and racism over Ngāi Tahu involvement in environmental management (see Chapter 6). These politics meant that Ngāi Tahu's representation on the Committee held a significance I hadn't realised. As a result I approached iwi representatives again and had face-to-face, phone and email conversations with the Ngāi Tahu advisor to the HWZC about how I might incorporate themes that were important to the iwi. As a direct result, I changed my schedule of questions for subsequent interviews to ask:

- Committee members "How valuable do you think rūnanga representation was on the Committee?"

- members of the public, "How important is it for local iwi to be involved in managing the Hurunui River? Do you think Ngāi Tahu representation on the HWZC was valuable?"

These questions proved to be extremely productive and generative. The Ngāi Tahu advisor and Te Rūnanga o Kaikōura representative also asked that I explore how the tourism 
industry, both locally and nationally, were understanding and contributing to debates about freshwater. Unfortunately, however, I was unable to explore these issues at the national level because doing so would require a significant addition to the scope of my study. Doing a rigorous and useful analysis of national tourism operators and freshwater debates would have required additional time and funding that I didn't have access to. I attempted to begin my examination of local tourism by talking to Ngāi Tahu Tourism, but my requests to interview someone were turned down twice. Given the small amount of commercial tourism directly involving the Hurunui River, I felt unable to pursue this avenue of inquiry any further.

The CWMS itself, and the Canterbury earthquakes, have seen a significant increase in Ngāi Tahu's workload, as well as their influence in the region. Legislation introduced in 2011 recognised Ngāi Tahu as a partner in the earthquake recovery, alongside local authorities, and the iwi has been at the heart of reimagining the city centre (McCrone, 2013). Because of Ngāi Tahu's growing commitments, I tried to cultivate an approach that invited contributions to shaping the research without making inappropriate demands on people's time and resources in an effort to gain a sense legitimacy for my work (Maxey, 1999).

\subsection{Case driven, multi-methods research}

This research takes a case driven approach - it focused on exploring the particular lived realities of changing environmental politics in Canterbury, and the way data generated "speaks to" theory. Throughout this inquiry 'data collection and analysis reciprocally inform and shape each other through an emergent iterative process' (Charmaz, 2011, p. 360). Undertaking research in this way involves constant reflection on language and meaning, and how themes that emerged during my fieldwork 'speak to' wider processes, contexts and theories (Knigge \& Cope, 2006). This meant incorporating relevant foci when their importance became apparent, and abandoning avenues of inquiry that were not generative or particularly important within that context. For example, while my central research question did not change, new themes, such as community based disciplining of difference, became apparent - research material repeatedly pointed to disciplining as a strong influence on the scope, possibilities for and the nature of environmental governance. Accordingly, the design of my project was adjusted to address this theme and 
one outcome has been that I have drawn on a number of bodies of literature to build an adequate framework for analysis and to examine how my case informs these literatures. In order to generate a rich body of texts, I adopted a multi-methods approach, a useful means for establishing trustworthiness in detailed case studies (Bradshaw \& Stratford, 2010). In the following sections, I explain how I engaged as a participant observer, conducted semi-structured interviews with a range of participants, and supplemented these methods with a short questionnaire to reach people who weren't engaged in formal political processes.

\subsubsection{Participant observation}

In order to explore how nature/society discourses competed within the Zone Committee space, I acted as a participant observer at HWZC meetings. Participant observation can enable a nuanced exploration of social life through an engagement with non-verbal forms of interaction between people and circulating emotions (Davies \& Dwyer, 2007; Hoggart et al., 2002). It also provides a means for identifying silences and exclusions, in this case, by a decision making body, for instance what was not discussed and who was silenced, things that are not typically included in meeting minutes. In these ways, participant observation can deepen understandings of case studies (Cook, 2005), as well as creating conversational spaces in which people can directly or indirectly shape the research.

I was a participant observer at twelve meetings, roughly every second scheduled meeting during a 20 month period between mid-2010 and early $2012 .{ }^{10}$ The dates and locations of meetings I attended are as follows:

$\begin{array}{ll}26 \text { July } 2010 & \text { Amberley } \\ \text { 16 August 2010 } & \text { Cheviot } \\ 20 \text { September 2010 } & \text { Culverden } \\ 8 \text { November 2010 } & \text { Leithfield } \\ 31 \text { January 2011 } & \text { Amberley }\end{array}$

\footnotetext{
${ }^{10}$ In addition to these scheduled meetings, the Committee also undertook an intense series of community meetings in late May 2011 about the programme of action they produced, as well as meetings with industry and interest groups which were often closed to the public. All of my requests to attend closed meetings, apart from one, were refused.
} 
14 March 2011

18 April 2011

30 May $2011^{11}$

18 July 2011

19 September 2011

14 November 2011

20 February 2012
Amberley

Amberley

Amberley

Amberley

Waipara

Hanmer Springs

Culverden

During the meetings I wrote detailed notes about both the interactions during formal Committee proceedings, as well as informal conversations that took place before and after meetings, and during breaks. These field notes are referred to throughout this thesis.

As Kearns (2010, p. 246) argues, there is 'no such thing as a non-participant in a social situation' - peoples' very presence alters social dynamics. However, as a method of investigation, there are different levels of participation ranging through observer, observer-as-participant (for instance a member of the crowd), participant-as-observer (typically, trying to make sense of the researcher's own locality) and complete participation (immersion in a community) (Kearns, 2010). I oscillated between observeras-participant and participant-as-observer, reflecting my sense of being from both "inside" and "outside" the District.

In some ways being at the meetings worked to reduce the distance between myself as "the researcher" and the participants as "the researched" - I talked with people informally in the breaks and shared transport to meeting venues with both Committee members and members of the public. Occasionally I participated in "break out" sessions in which small groups of Committee members, the public, and regional and local government representatives discussed aspects of water management. In others ways, however, it reinforced this separation. My role of observer and researcher was obvious to everyone as I madly took notes, for instance, when conflict erupted, and sometimes informal conversations were characterised by my feelings of discomfort as I uncertainly and awkwardly performed as an academic. Conversely, perhaps this discomfort meant that I

\footnotetext{
${ }^{11}$ This meeting was initially advertised as public, before then being made a closed meeting. I was given permission to attend this meeting, partly on the basis that I had already made travel arrangements.
} 
was seen as unthreatening, and maybe participants shared information they wouldn't have with an established, male academic (England, 1994). Participant observation was a useful method for exploring the nuanced relationships of power that flowed across the Committee space, and between me and the people I was researching with. Used in combination with semi-structured interviews, it can also help to identify people to interview, and build a degree of rapport that can make interviews more comfortable.

\subsubsection{Semi-structured interviews}

I began interviewing people soon after the first HWZC meeting and ultimately carried out 42 semi-structured interviews. Although focus groups have shown how social interactions can be a productive tool in geographical research (McGregor, 2005), I was conscious of what group based discussions might mean for participants' feelings of safety and willingness to participate in a high-stakes context. An advantage of interviewing people one on one was that I could be more sensitive and attentive to the stories individuals wanted to tell, 'allowing interviewees to construct their own accounts of their experiences by describing and explaining their lives in their own words' (Valentine, 2005, p. 111). Semistructured interviews were a method that enabled the research participants and I to explore how people understood the relationship between people and nature, and their perceptions of political processes and governance arrangements affecting this relationship.

The first interviews were with HWZC members. Eleven of the 12 people who worked on the Committee participated in the research; only one didn't respond to requests for an interview. A Ngāi Tahu advisor also sat around the Committee table but wasn't officially a member. Given the importance and influence of this role to the HWZC, the advisor was also interviewed, as was the Committee facilitator. The first round of interviews with this group took place between August 2010 and May 2011, and they were interviewed again during February and March 2012. The reason for interviewing them twice was to capture how hopes and aspirations for the Committee and understandings of nature/society discourses changed through their work developing a programme of action. In addition to the Zone Committee, a range of members of the public were interviewed. I asked people who I saw at HWZC meetings, people who were represented in the media, council officials and public figures in the Hawarden Waikari area to participate (see Figure 3). I also drew 
on snowball sampling, asking participants to name others that might be interested in being interviewed (Bradshaw \& Stratford, 2010; Valentine, 2005). Snowballing proved to be very effective and I was able to interview a wide range of people that had diverse interests in the Hurunui River (see Table 1). The members of the public interviewed included several people who advocated for freshwater quality and access, a school principal in the area, two farm owners and irrigation advocates, and someone who worked on developing dam proposals. These people talked about a diversity of understandings of the Hurunui River including their whakapapa connections, agricultural and commercial interests, commitments to the commons, wilderness interests, concern for public health and the livelihood of the Hurunui area, and desires to sustain a site of recreation and joy. I also interviewed the principal planner for ECan, and an ECan commissioner who had been involved in HWZC politics. Participants who weren't Committee members were interviewed in October and November 2011 during an extended stay in Canterbury.

While most people consented to having their real name used in publications, I decided not to use them. This is largely because of the contentious nature of Hurunui River politics, and the threats of violence that had emerged (see Chapter 5). While many of the participants will still be readily identifiable to those who are familiar with the case, differentiating between them by using pseudonyms and the date of the interview (e.g. Joanne 5 November 2011) is an attempt to create a degree of anonymity.

Interviews lasted from half an hour, to almost two hours, and were audio recorded. I had a set of a dozen guiding questions and typically asked most of them but also explored issues that came up and often gently prompted participants to expand their responses. Separate but similar interview schedules were developed for Committee members and the public (see Appendix C). The guiding questions provided me with a useful prompt, enabled some consistency across interviews and gave me confidence that the interviews I was undertaking were exploring specific areas of interest in a sufficiently flexible but comprehensive manner (Valentine, 2005). Participants were reminded that they could decline to answer questions, and could stop the interview at any time. When first interviewing people, I asked them to tell me about themselves and their background and this was often a good "warm up", allowing the interview relationship to develop in an easy, reciprocal manner. At the end of each interview, participants were asked if there 
Table 1 Table of participant codes and descriptions and dates interviewed

\begin{tabular}{|c|c|c|}
\hline $\begin{array}{l}\text { Participant code } \\
\text { name }^{12}\end{array}$ & Interest/connection to the Hurunui River ${ }^{13}$ & Date(s) interviewed \\
\hline Hamish & HWZC appointed community member & $\begin{array}{l}11 \text { August } 2010 \\
16 \text { February } 2012\end{array}$ \\
\hline Max & HWZC appointed community member & $\begin{array}{l}12 \text { August } 2010 \\
22 \text { February } 2012\end{array}$ \\
\hline Tim & HWZC appointed community member & $\begin{array}{l}3 \text { November } 2010 \\
14 \text { February } 2012\end{array}$ \\
\hline Duncan & HWZC appointed community member & $\begin{array}{l}4 \text { November } 2010 \\
20 \text { February } 2012\end{array}$ \\
\hline Brad & HWZC appointed community member & $\begin{array}{l}5 \text { November } 2010 \\
21 \text { February } 2012\end{array}$ \\
\hline Brian & HWZC appointed community member & $\begin{array}{l}1 \text { February } 2011 \\
16 \text { February } 2012\end{array}$ \\
\hline Shona & HWZC appointed community member & 30 May 2011 \\
\hline
\end{tabular}

${ }^{12}$ Although I conducted 42 interviews, one participant chose to withdraw after reading the transcript of their interview. Although they were vague about their reasons for withdrawing they mentioned that perspectives and feelings in their community had changed in the intervening 12 months since we had been in contact, and they didn't want to be associated with the project anymore. Despite offering to take extra measures to ensure they were not readily identifiable in communicating my research, the interviewee retracted their transcript.

${ }^{13}$ The descriptions of participants' interests and connections are reductive, intended to give a brief overview of the range of participants while also attempting to ensure a degree of anonymity. Some specific role descriptions are included where necessary to a full analysis of this case; these participants gave permission to do so. 


\begin{tabular}{|c|c|c|}
\hline & & 18 March 2012 \\
\hline Donald & $\begin{array}{l}\text { HWZC member for the Hurunui District } \\
\text { Council }\end{array}$ & $\begin{array}{l}3 \text { November } 2010 \\
21 \text { February } 2012\end{array}$ \\
\hline George & HWZC member for ECan, ECan commissioner & $\begin{array}{l}11 \text { August } 2010 \\
14 \text { February } 2012\end{array}$ \\
\hline Rob & $\begin{array}{l}\text { HWZC member for Te Rūnanga o Kaikōura } \\
\text { until September } 2010\end{array}$ & 16 August 2010 \\
\hline Joyce & $\begin{array}{l}\text { HWZC member for Te Rūnanga o Kaikōura } \\
\text { after September 2010, Ngāi Tahu advisor to } \\
\text { the Committee prior }\end{array}$ & $\begin{array}{l}18 \text { April } 2011 \\
15 \text { February } 2012\end{array}$ \\
\hline Mikaere & Ngāi Tahu advisor to the HWZC & $\begin{array}{l}22 \text { July } 2011 \\
21 \text { February } 2012\end{array}$ \\
\hline Chris & HWZC facilitator & $\begin{array}{l}12 \text { August } 2010 \\
23 \text { February } 2012\end{array}$ \\
\hline Louis & Member of the public & 31 October 2011 \\
\hline Henry & Member of the public & 1 November 2011 \\
\hline Joanne & Member of the public & 5 November 2011 \\
\hline Gus & Member of the public & 14 November 2011 \\
\hline Ben & Member of the public & 14 November 2011 \\
\hline Nick & Member of the public & 17 November 2011 \\
\hline Allan & Member of the public & 17 November 2011 \\
\hline Victoria & Member of the public & 22 November 2011 \\
\hline Moana & Member of the public & 22 November 2011 \\
\hline
\end{tabular}




\begin{tabular}{|l|l|l|}
\hline Arthur & Member of the public & 23 November 2011 \\
\hline Anna & Member of the public & 24 November 2011 \\
\hline Ruth & Member of the public & 24 November 2011 \\
\hline Julia & Member of the public & 28 November 2011 \\
\hline James & Ngāi Tahu Property representative & 29 November 2011 \\
\hline Luke & ECan officer & 29 November 2011 \\
\hline Howard & ECan commissioner & 23 February 2012 \\
\hline
\end{tabular}

was anything else they wanted to add, and many people spoke about issues that were important to them that I hadn't (adequately) asked about.

Most of the questions on my interview schedule were easily answered, apart from one that sought to understand emotional geographies of the debate about the Hurunui River (see Davidson et al., 2007). I asked participants to 'tell me about a time when you've been in, on, or around the Hurunui River, or another river. Describe the river to me. How did you feel when you were there?' Some people provided interesting and detailed responses. For one participant, the question provoked a strong emotional reaction; she described feeling 'exhilarated and over-awed and humble' around the river (Joyce 15 February 2012). Others seemed uncomfortable. For example, one male participant responded to the question with 'Oh wow, that's a bit soft isn't it [laughs]? No, I won't say that, it's a bit sexist [laughs]' (Gus 14 November 2011). This attitude reflects hegemonic masculinities in Aotearoa New Zealand (Liepins, 1998) and after this interview, I occasionally didn't ask male participants this question until the very end of the interview, or at all, because it felt uncomfortable, as if I was prying into peoples personal lives when the personal and political are so often understood as dichotomous. These responses were interesting, highlighting the effects of discursive norms that made it uncomfortable for men, and other people, to talk about how they felt about the river.

Doing interviews in a rural setting raises a particular set of considerations about where interviews are held and researcher safety. Choosing an interview site is important in 
shaping the way participants felt and what they chose to discuss (Anderson et al., 2010; Elwood \& Martin, 2000). In arranging interviews, I offered to meet participants where they felt most comfortable, whether that was their homes, a café or public space. Occasionally, I offered to meet research participants at my Mum's home in Christchurch, or my Granny's house in Amberley, an offer taken up by two participants. These two instances provided an interesting contrast to interviews in participants' own homes or more public spaces. I felt a degree of discomfort because of my own feelings of privacy, and the participants also seemed more uncomfortable. In each instance, other family members - my brother, and my Granny - were also home, although in separate rooms and out of ear shot. Their presence nearby, however and the "private" household setting meant both interviews seemed slightly stilted and unsettled.

A different kind of challenge arose when I visited participants' homes, particularly when it came to talking to people who had stayed outside the HWZC process and I didn't know. Many lived rurally, and there either weren't any cafés or public spaces nearby, or participants simply chose their own homes when I asked where they would like to do the interview. To increase participants' comfort, and to minimise the 'intrusion' of my fieldwork (England, 1994, p. 85), I felt that it was necessary that the interviews were held in their homes. At the time, my primary supervisor and I discussed the risks involved, particularly as I was never sure how much cell phone coverage there would be should any form of trouble arise. We agreed that the best way forward was to seek out public spaces where possible, but where it wasn't I would keep my phone close by as well as telling someone where I was going and what time I would be back (Valentine, 2005). Interviews at peoples' homes were generally the most comfortable, and often took a more conversational and relaxed tone as people drew other family members into the discussion.

In another instance that highlighted the relational and contingent nature of doing research, a participant sent me an email and text message that left me feeling deeply uncomfortable (see Diprose et al., 2013 for a fuller account and analysis of this interaction). In contrast to my efforts to position myself as a professional yet friendly and approachable researcher this participant made comments that indicated he understood me as sexually available. For me, this was a deeply unsettling experience, one that saw me question whether I was a "good researcher" as the way he understood me was very different to the kind of researcher I was trying to (dis)embody. Despite having read about 
feminist methodologies and rejections of objectivity and neutrality, I found myself poorly equipped to deal with being constructed as an object of desire (see Cupples, 2002). I was nagged by a degree of shame that I had not performed well (Brown, 2007), a feeling that was supplemented by a persistent sense of self-doubt throughout my research as I uncertainly navigated what it meant to be a "good" academic. After this experience there were many times I was plagued by this self-doubt, uncomfortable during the breaks at Zone Committee meetings interacting with people I didn't know and worried about my safety as I arranged interviews (see Scheyvens \& Nowak, 2003). At these points I certainly didn't feel like I was "the powerful researcher" (Sharp, 2005).

One way of navigating this discomfort was to increase the sense of distance between myself and research participants, a move that was also made in response to the tense political situation. As I learnt more about Hurunui River debates, it was clear that there were intense divisions between people and groups characterised by passion, anger and upset. The situation meant that I found it increasingly hard to take an open stance against neutrality (Cahill et al., 2007) without jeopardising research relationships, as illustrated by the opening section of this chapter. The accusation that I had produced an anti-dam brochure was very alarming, and I felt that my continued access to people rested on them understanding me as being largely neutral and objective, despite my commitment to the idea that research could not be separated from my own experiences and philosophical positions (Hoggart et al., 2002). Like McDowell (2010, p. 164) I quickly realised that despite my belief in 'honesty and openness', pursuit of such qualities may 'conflict with access [to research participants and sites] and the quality of the research encounter'. Conversely, sometimes I found myself resorting to positivist understandings of a researcher as someone who maintains an appropriate degree of distance, is non-sexual and unclouded by emotions (Bondi, 2007). This was particularly so after the participant mentioned above made apparent his understanding of me as sexually available. As I maintained an arm's length from participants to avoid further similar positionings or accusations of bias, one potential interviewee avoided invitations to take part, warning that she wouldn't be 'had' by some academic. I tried to build rapport with her and ultimately she did agree to be interviewed, was open and friendly, and has maintained an interest in this project. Negotiating questions of distance and openness caused me to reflect on how to maintain an ethical approach to research in a tense context, and highlighted the often tricky and complicated work of securing agreement to participate, creating comfortable, productive 
and safe encounters while also maintaining the degree of openness and honesty in the research endeavour I sought (McDowell, 2010).

\subsubsection{Short interviews}

One particular challenge of this project was to access people that are connected in some way to the Hurunui River but were less visible in public debates. In particular, I wanted to seek out those who had remained outside the HWZC process and were unrepresented in media and activist groups. I sought to capture the views of some of these people to gauge how debates about the river were understood, and to find out about ways of valuing nature that may be absent from political spaces and why. Due of their lack of visibility in formal spaces, these people were difficult to identify and talk to. To address this gap, I developed a short, semi-structured interview schedule. In November 2011, I visited a number of public sites within the Hurunui District boundaries and interviewed 12 people. Questions were open-ended and took between five and fifteen minutes to carry out. I asked participants to describe the debate about the Hurunui River, what they knew about the HWZC, who should be involved in water management, and how important iwi involvement was (see Appendix C). I was conscious that limiting the short interviews to people in public places within the District might fail to capture people living outside territorial boundaries who felt connected to the river, yet these limitations made the short survey manageable.

These short format interviews were conducted over a couple of days at public sites chosen in an attempt to garner diverse views. Thinking about my own safety, I also selected places people frequented so as to avoid being isolated. These sites were:

- A local Playcentre

- Outside the general store in Hawarden

- A golf club

- The Hurunui River mouth

- A café in Waikari

- The staffroom of a school.

As the list shows, the "public" nature of the locations varied somewhat - from a general store, to the relatively "private" space of the school staffroom that I was invited into. The 
interviews were extremely valuable for highlighting issues that I could then follow up during semi-structured interviews with other participants. In particular, findings indicated the degree of community disciplining that was happening, information that I then explored in semi-structured interviews with some of the participants listed in Table 1. This then formed the basis of Chapter 5 .

\subsection{Responsive and accountable research - analysing and writing}

The mixed methods approach I adopted provided a very rich body of material that could be brought together with existing political ecology literature (Valentine, 2005). All of the interviews were transcribed, and then sent back to participants, with the offer that they could suggest changes or additions. While most people didn't respond, whether due to other demands on their time or disinterest, those that did suggested minor corrections. Almost all who responded mentioned their discomfort at reading conversational language turned into the written word. This is one of the challenging dimensions of "writing in" research (Mansvelt \& Berg, 2010), and transforming oral texts into written texts. Sending transcripts back to participants not only gave them a degree of control over the material, but created possibilities for reflection and scrutiny that are important to accountable and trustworthy research praxis (Bradshaw \& Stratford, 2010).

In adopting a feminist, case study driven approach, my process of analysing interview transcripts and field notes was both inductive and iterative - as I carried out fieldwork, and analysed field notes and interview transcripts I considered emerging themes. These themes and categorisations were constantly revised as I interrogated the data, and drew on literature, and my knowledge and experiences of the case study (Charmaz, 2011). Moving back and forth between categories and research material was a useful way of identifying significant themes that addressed the research questions and "spoke to" theory. Part of this process was using these themes as the basis of codes that were used to manually sort interviews, field notes and secondary materials such as minutes of HWZC meetings and news reports. These codes then allowed me to organise my thinking and make sense of the project (Crang, 2005). This approach to analysis that compares multiple sources of information is an important dynamic of establishing trustworthiness (Bradshaw \& Stratford, 2010). In "writing in" this research, I wove thick descriptions together with a number of bodies of literature. The following chapters begin with theory before turning 
to, and drawing it together with, research data. Chapters are structured in this way to make clear from the outset the theoretical frames that will both elucidate the case, and be shaped and developed through the data.

Another aspect of "writing in" that required careful consideration was the role of language and how it constitutes the very things it names (Butler, 1993). Writing, according to Mansvelt and Berg (2010, p. 343), 'constructs what we know about our research but it also speaks powerfully about who we are and where we speak from', and forms 'a particular and partial story'. Throughout this thesis I have included extensive quotes from participants, in the belief that each participant offered unique ways of narrating environmental politics. I was aware, however, that I had the ultimate control over the writing and dissemination processes. This required a careful approach to my writing, the language I used, and the type of works that were produced (McDowell, 2010).

Accountability is also an important dimension of decolonising research and feminist approaches that seek to address power imbalances (Smith, 1999). As I went about "writing in" I sought to maintain a reflexive approach to my research that involved thinking carefully about how it fit with post and anti-colonialisms. Accordingly, I shared an early version of Chapter 6 with the Ngāi Tahu advisor to the HWZC. He emphasised that in writing about this data it was important to acknowledge that Indigenous people develop and live their worldviews and we talked about how to avoid environmental movements claiming and abstracting Indigenous ideas. Research findings will also be communicated and discussed in a number of ways. Firstly, a general findings report will be circulated to all participants that indicated they wanted a copy. Secondly, a report will be developed specifically for Ngāi Tahu and the rūnanga that compiles responses to the questions that were added to the interview schedule. And thirdly, a public forum will be held in Canterbury to discuss findings and invite feedback and further conversations. The fact that these opportunities for reflection, discussion and adjustment of my research are happening after I submit this thesis is something I feel critical of. I would have preferred to have this form of peer review and discussion take place prior to submission, or even explore the possibilities of adopting authorship practices that are more reflective of co- 
constituted knowledge (Watson \& Huntington, 2008). However, I have been constrained by institutional expectations to produce single authorship work and to finish quickly. ${ }^{14}$

\subsection{Conclusions}

In adopting a feminist poststructuralist approach that rejects the notion of researcher objectivity and claims to universal truths, this thesis is not concerned with uncovering "reality", but rather exploring how meaning is made, remade and destabilised in Hurunui River politics. In this chapter, I have situated myself as a co-producer of knowledge. I have also attempted to carry out a process of reflection about my position within knowledge production that is outward looking and relevant to the overall activist scholar ambitions of this thesis - to speak to, and challenge, social and environmental injustice how and when I can (Kobayashi, 2003).

In order to do engaged, outward looking research from a feminist orientation I have adopted an approach to ethics that goes beyond formal, committee approval. While seeking to do research in a manner that fits with feminist geographers' emphasis on unsettling power relations and notions of neutrality, it was important to be context appropriate when tensions over the future of the river were running high. Reflexive, responsible and ethical research can be difficult - for me it involved tricky negotiations of my commitment to honesty, and the fact that openness about my activist scholarship may have jeopardised access to participants and "good data". It has meant acknowledging my insecurities as an academic, and the uncertainty of my performance of this role, and attempting to cultivate and ethic of care for myself and others in the process (Diprose et al., 2013). Feminist research also has ongoing resonances in terms of continuing to be responsible and accountable to communities I researched with, and in (post)colonial settings, particularly Indigenous communities.

\footnotetext{
${ }^{14}$ I have also faced significant pressures flowing from limited funding that were exacerbated by cuts to state support for post-graduate students (see The New Zealand Herald, 2012). Limited funding has contributed to my own desire to finish quickly as my student loan rapidly grows. Although the neoliberalised user-pays university in Aotearoa New Zealand suggests possibilities and opportunities for postgraduate researchers (NZGS-PG Network, forthcoming), in many ways, it also creates pressures that work against engaged research that is responsible and accountable to participants (Cupples \& Pawson, 2012) and happy and healthy lives for academics.
} 
This chapter has described the methods I used to gather a rich body of information that enabled me to explore understandings of nature/society relationships, and how they were affected by changing political processes. The remainder of this thesis examines the themes that were identified through an inductive and iterative process of analysis. Working from an engaged and accountable feminist and (post)colonial orientation, this project charts uneven relations of power and contributes to the intellectual work required to address these inequalities and their effects on nature and society. 


\section{Reregulating freshwater in Canterbury}

\subsection{Introduction}

Nature is at the core of neoliberalisms (Heynen et al., 2007b). As market logics are extended, neoliberalisms - the plurality of ways neoliberal reforms are enacted and experienced - seek out domains for capture and commodification, and have invariably turned to the biophysical world. The different ways in which nature is reregulated has important implications for how nature is valued, how people access and interact with the biophysical world and in turn, environmental health (Castree, 2011b). In the 1980s and early 1990s Aotearoa New Zealand was the site of some of the most rapid and deep neoliberal reforms, often call the "New Zealand Experiment" (Kelsey, 1995), and these reforms extended to the environment. However, neoliberalisation is a process and it didn't end in the 1990s. This chapter explores key neoliberalising processes and focuses on a recent manifestation when in 2010 the national government deployed political technologies that significantly reworked democracy in the Canterbury region, and created the tools to hasten the enclosure of rivers and lakes.

In order to develop a critical analysis of neoliberalisations of nature in Aotearoa New Zealand I first draw out recent conceptualisations of neoliberalisms and debates within critical geography about how to understand neoliberal processes and effects. In particular, the section will explore the productive tensions between political economy and poststructuralist approaches. I then turn to an examination of the ways political ecologists have characterised the intersections of neoliberalisms and the biophysical world, and explore the broadening scope of this body of literature. The remainder of the chapter will 
briefly introduce the context and effects of the New Zealand Experiment, with particular regard to environmental reforms. I then chart changes to water management in the Canterbury region of Aotearoa New Zealand by exploring how 'neoliberalism has been constituted in and through reconfigurations of environmental governance' (McCarthy, 2005, p. 1007). To date, there has been little literature that employs a political ecology framework to explore the intersections of neoliberalisms and nature in Aotearoa New Zealand (for exceptions see Hobson Haggerty, 2007; Memon \& Kirk, 2011). Addressing this gap is important given the way that actually existing neoliberalisms have varied, and had varying effects, across space and time. This chapter makes a modest contribution to neoliberal natures literature and Aotearoa New Zealand geographies exploring neoliberalisms. It also establishes links between neoliberalising natures literature and theorisations of democracy.

There is a growing body of literature that explores how emerging inequalities highlight the failings of neoliberalisms, and the impetus this has given states to rework democracy (Purcell, 2009; Swyngedouw, 2009). While the state has always played a key role in enabling neoliberalisms, governments and elites have had to undertake significant work to address these inequalities, which Purcell argues has produced 'democratic deficits' (Purcell, 2009, p. 141). However, there is little literature that uses this branch of critical geography to explore specific case studies of how democracy is constrained to protect the neoliberalisation of the environment, particularly beyond urban settings. In the Canterbury region, efforts to achieve broadly conceived neoliberal ends were achieved through unprecedented state intervention and reregulation, actions that require careful analysis in order to understand the links between state, neoliberalisms and natures. In order to make sense of this state intervention into regional politics, I draw together literature examining democracy and the state, and the extension of market logics into the environment through suspended democratic rights (Agamben, 2005; Dean, 2010; Swyngedouw, 2009). 


\subsection{Neoliberalising natures}

\subsubsection{Neoliberalisms - ideology, reform and practices}

In the 1970 s the Keynesian model of government, characterised by attempts to balance social welfare with business interests and frequent government intervention, was perceived by many to be failing (Harvey, 2005; Larner, 2011). In the face of ballooning unemployment and inflation in the developed world, and debt crises in the developing world, neoliberal ideology gained prominence as seemingly the most viable alternative to Keynesianism. Developed in the 1940s, neoliberal ideology represents an attempt to protect individual freedoms (liberalism) and simultaneously advance neoclassical ideas of the free market economy (Harvey, 2005). As a theory it is based on the idea that human interests are best served by 'liberating individual entrepreneurial freedoms and skills within an institutional framework characterized by strong private property rights, free markets, and free trade' (Harvey, 2005, p. 2). Lewis (2009) argues that the architects of neoliberal ideology sought to create an environment where less privileged people would have equal opportunities to pursue wealth through entrepreneurialism. However, Brenner and Theodore (2007, p. 154) distinguish between neoliberal ideology developed by Friedrich von Hayek and Milton Friedman, and 'actually existing neoliberalism' to highlight the ever evolving, contradictory nature of neoliberalisms in practice and their diverse outcomes (see also Beeson, 2007). As neoliberal principles have been adopted by various governments - from Pinochet's far right dictatorship in Chile, to social democracies such as that in Aotearoa New Zealand - it is clear that context plays a significant role in shaping neoliberal policy and its effects. This diversity of interpretations and applications, as well as the way gender, race and class affects how reforms were and are experienced, has led many academics to argue for a discussion of neoliberalisms in the plural (England \& Ward, 2007; Howitt \& Hillman, 2010; Larner, 2003; Larner \& Butler, 2007; Mansfield, 2004).

Diverse neoliberal laissez-faire policies have often been characterised by 'rolling back state supports in social services and welfare, reducing taxation, privatizing government services such as education and health care, extending private property rights, liberalizing trade, and rescaling governance' (Dempsey et al., 2011, p. 238). However, both the retreat of state support and state extension into facilitating and securing particular scales of governance are essential to the functioning of neoliberalisms (Harvey, 2005; Peck \& 
Tickell, 2002). Ward and England (2007, p. 15) describe this as the 'qualitative restructuring' of the state, that is, the role of the state is not so much reduced as it is reworked. States are the very institutions that implement neoliberal reforms and through policy decisions determine how neoliberalisms are enacted (Ward \& England, 2007).

Geographers working in Marxist traditions have sought to identify some of the shared features and impacts of neoliberalisms by exploring 'its macro-political, contextual, and inter-institutional logic' (England \& Ward, 2007, p. 257). Marxist geographers have, importantly, drawn attention to and furnished critiques of political economic processes, particularly as they take shape at the nation-state scale (Peck \& Tickell, 2002). For example, despite claims to founding principles of freedom and choice, David Harvey (2005) illustrates that generally the application of neoliberal ideology has been characterised by rising social inequality within states. He argues that rather than this being an unexpected consequence, inequality has been the intentional effort to shore up, or where necessary create, the power of economic elites. This elite class has captured significant media and political control, which is then used to convince people that neoliberal reform has increased their own freedoms despite the growing inequalities (Harvey, 2005). Harvey (2005, p. 3) argues:

Neoliberalism has, in short, become hegemonic as a mode of discourse. It has pervasive effects on ways of thought to the point where it has become incorporated into the common-sense way many of us interpret, live in, and understand the world.

While there are undoubtedly intentional efforts by groups of people who benefit from neoliberal configurations to spread and sustain reforms, political economy analyses have been critiqued as being universalising and failing to adequately explore how and why neoliberalisms are incorporated in everyday common sense (Larner, 2003).

Geographers informed by poststructuralism and feminist scholarship have argued for greater attention to the messy lived realities and inconsistencies of neoliberalisms (Gibson-Graham, 2006). They argue that neoliberalisms are processes, rather than fixed end points, and therefore we need to be attentive to agency and the potential to expose and exploit cracks in neoliberalisms, as well as already existing alternatives and yet to exist possibilities (Gibson-Graham, 2006; Lewis, 2009). The work of these geographers in 
particular has revealed the lack of coherence in how the ideas of Friedman and Hayek are adopted and applied (Ward \& England, 2007). Neoliberalisms are enacted in a variety of ways in a variety of contexts with a variety of outcomes, and are similarly contested (Larner, 2003; Springer, 2012b). Wendy Larner (2000a, 2003) argues that as the theoretical approaches of geographers to neoliberalism have become more nuanced, it is important that we now turn away from describing neoliberalisms as monolithic and inevitable. Describing them in this way reinscribes hierarchical power relations that act to mask neoliberalisms' diversity, incoherence and moments of instability. Focussing on the grand narratives of neoliberalism does not allow for an analysis of the 'complex appeal of concepts such as 'freedom', 'empowerment', and 'choice"' (Larner, 2003, p. 511). Without thinking about this appeal, it's hard to understand why people may act as neoliberal subjects (Larner, 2003).

To avoid overemphasising the power of governments and elites (Nairn \& Higgins, 2007), Larner (2003) encourages geographers to bring together Marxist and poststructuralist approaches to studies of the impacts of neoliberalisms and how they are productive of space and subjectivities. Such an approach calls attention to 'broad political, economic, cultural, and ecological relations and understanding how these are articulated, expressed, and resisted in the ideologies and techniques of power of everyday life' (Ekers \& Loftus, 2008 , p. 712). It enables an examination of themes such as imperialism and postcolonialism, as well as personal, embodied and gendered experiences (Lewis, 2012). Bringing together poststructuralism and Marxist geographies to explore the everyday lived experiences and performances of neoliberalisms, while acknowledging the interconnections between them (Peck, 2004), carves space for 'resisting and reworking neoliberalism' (Ward \& England, 2007, p. 19). Barnett (2005) argues that the two approaches are too ontologically polarised, yet successful attempts to draw them into conversation (for example Ekers \& Loftus, 2008; Gibson-Graham, 2006) indicate they can be held together in 'productive tension' (England \& Ward, 2007, p. 259). Holding poststructuralism and political economies together is made easier by a weak theory approach (Gibson-Graham, 2006), which involves 'identifying, accepting and examining multiple, uneven and paradoxical expressions of governmental and political power' (Larner, 2011, p. 332). 
Throughout this thesis, neoliberalisms are understood as discursive assemblages, produced by a range of actors at numerous scales. The assemblages are multiple, contradictory, at times descending into incoherence, contested and contestable, and are different across space (Gibson-Graham, 2000). Neoliberal processes are characterised by uneven and changing power relationships, where power is relational but concentrates unevenly. The state plays a pivotal role in advancing neoliberal theory, but the state (as well as government and elites) is not a fixed category. Rather the state, government and elites are 'emergent effects of multiple projects, practices, and attempts to institutionalize political power relations' (Jessop, 2007, p. 38). Power is always unstable, but consolidates at different points at different times. This approach enables greater attention to the possibilities of agency, and the potential for new subjects to appear within the cracks and paradoxes (Butler, 1993). As Lewis (2009, p. 118) argues, we must be attentive to the fact that 'the political process throws up opportunities, and there are ways to identify, elaborate and foster them, even if there are powerful actors, projects, alliances, and deeply inscribed trajectories that restrict and will shift and reform to eliminate alternatives'. Recognising this instability enables hopeful resistance to the various violences of neoliberalisms (growing inequalities, othering, alienation from access to the biophysical world) and opens our 'imaginations to the possibility of (re)producing space in ways that make possible a transformative and emancipatory politics' (Springer, 2012a, p. 141).

\subsubsection{Neoliberalisms and the biophysical world}

A significant body of literature connecting the effects of neoliberalisms on nature/society discourses has emerged in the past decade (Castree, 2008; Harris, 2009). In the introduction to Neoliberal Environments, Heynen et al. (2007b) argue that neoliberal reform has seen the extension of capital accumulation into the biophysical environment, so environmental change is an inherent aspect of neoliberalisms. These processes are exacerbated by a focus on individual 'rights and freedoms', in particular private property

rights. Neoliberalisms produce varying outcomes in different settings, but Castree (2011b, p. 36) contends the result is always 'a shift in social relations to the non-human world'. Political ecologists have sought to explore this shift, and the processes through which neoliberalisms are extended to, and contested and reworked through the environment (Heynen et al., 2007b). 
The extension of neoliberalisms in relation to managing the environment is closely linked with Garrett Hardin's seminal articles 'The tragedy of the commons' (1968) and 'Living on a lifeboat' (1974). In these works, Hardin, who understood nature as discrete from humans, claimed that common resources cannot be effectively managed if there is open access to the environment because the very nature of the "rational economic man" means he will pursue his self-interest to the detriment of everyone else. Hardin argues that the persistence of the commons, in any form, is dangerous because without rules regulating self-interested behaviour, the commons will be overused and its utility eventually extinguished for everyone (Mansfield, 2004). His answer, whilst acknowledging that it is unjust, was to enclose the resource and allocate property rights over it so that it can be governed by market rationality as private property, or by the state. Hardin posited that exclusive private property rights would prevent people exploiting the individual benefits of over using the commons, which outweighs the shared cost of that overuse and subsequent degradation (Hardin, 1968). Nature, according to Hardin, was threatened by humans and in need of careful governance (Agrawal, 2005).

Hardin's claim that '[f]reedom in a commons brings ruin to all' (1968, p. 1244) aided neoliberal claims that private property rights are natural. According to this line of thinking, through the allocation of private property rights the motivations of the rational economic man can be harnessed to produce both economic and environmental benefits (Mansfield, 2004). Securing nature through private property rights has been a vital part of all forms of capitalism (Smith, 2006a), yet neoliberalisms have seen the accelerated alienation of people from the commons as the domain of the free market has been extended (Monbiot, 1994). Neoliberalising nature has required simultaneous institutional change (see below) as well as a discursive remaking of nature. As Bakker (2002) illustrates using the example of water, within neoliberalisms nature is no longer framed as a public good with common access that is tied to citizenship. Rather it becomes a commodity that is allocated via the market and accessed by consumers. This reconceptualisation is necessary to and perpetuated by four broad 'relations' often involved in neoliberalising nature (Heynen \& Robbins, 2005, p. 6). The first relation is governance, specifically reform based on the assertion that the state is not capable of delivering services efficiently to people and therefore needs to create space for market regulation. This requires the state to reregulate (rather than simply deregulate) in order to create conditions that are conducive to increased market control of nature, specifically the extension of private property rights 
and increased commodification (Bakker, 2003; McCarthy \& Prudham, 2004; Peluso, 2008). State power may also be devolved to local and regional governments or groups. Market governance of nature rests on the second broad relation - the enclosure of the commons. The process of enclosure involves excluding all or selected groups of the public. By enclosing the environment, nature is opened up for capital accumulation (McCarthy \& Prudham, 2004).

The third broad relation is privatisation, a form of enclosure that sees the transfer of resources held in trust by government authorities into private hands. Governments are seen to be inefficient and inappropriate regulators (Harvey, 2005); individuals and companies are more suitable actors to 'harness people's supposedly innate profit motives for the good of all' (Mansfield, 2004, p. 315). Privatisation also rests on the (mythical) benefits of the trickledown effect. Because of the difficulties of capturing nature, privatisation can take a variety of forms, including hybrid management models that include the public in decision-making, or privatisation of management, rather than ownership, of a resource (Bakker, 2007).

Once nature is privatised, it must be made tradable in order to be fully incorporated into the market led economy. This requires monetary valuation. By way of this fourth relation the environment is reduced to 'discrete quantities' (St. Martin, 2005, p. 70) that are commodified through a pricing regime, for instance paying for a fishing quota. Pricing regimes are an attempt to apply profit motives to the environment so that the market can produce greater innovation and efficiency through competition, while also attempting to manage externalities through financial incentives or disincentives. Remaking and circulating nature as a commodity requires significant work (Prudham, 2009). Commodification entails:

interlinked processes whereby: production for use is systematically displaced by production for exchange; social consumption and reproduction increasingly relies on purchased commodities; new classes of goods and services are made available in the commodity form; and money plays an increasing role in mediating exchange as a common currency of value (Prudham, 2009, p. 125).

Through these broad relations the environment is redefined as an economic good, and broadened private property rights, market allocation of resources, and pricing regimes to 
incorporate environmental externalities are intended to create greater efficiencies (Bakker, 2005).

The relations involved in neoliberalising nature are intimately tied to Eurocentric understandings of nature as separate from and inferior to humans (Suchet, 2002). In particular, private property rights value nature as consisting of passive objects (Bennett, 2004) to be managed, used for economic gain or preserved in a human-less state. Neoliberalised nature/society relations often come into conflict with and enter into conversation with other ways of relating to the nonhuman world, as well as conflicting with the biophysical world itself. Heynen et al. (2007a, p. 289) claim that the central assumptions in neoliberal reforms about 'markets and property are overwhelmingly mismatched to the character and quality of biophysical systems, and their functions and flows.' This mismatch has come at an enormous environmental cost as materials and energy from the biophysical world have fuelled economic growth (Castree, 2009). Indeed capitalist progression rests on this exploitation (Brenner \& Theodore, 2007). Environmental externalities, such as carbon emissions and water degradation, are the result of a systemic privileging of economic growth. However, rather than address the systemic causes, in many instances, neoliberal policies have been expanded through further privatisation and market control to encompass these externalities, most notably through carbon taxes (Harvey, 2005; Prudham, 2009). These instances, and recent financial crises, have highlighted the adaptability and resilience of neoliberalisms.

Given political ecology's roots in political economy studies, academics working in this tradition have worked to identify broad characteristics of neoliberal natures, as evidenced by Heynen and Robbins' (2005) four relations. However, Bakker (2010) warns that much of the political ecology literature adopts the universalising tendencies that Larner (2007) is so critical of. This is of concern because reifying neoliberal approaches to nature as coherent, monolithic and inevitable renders them beyond critique and beyond challenge. Bakker (2010, p. 14) argues that acknowledging the plurality of neoliberalisms 'suggests the possibility that outcomes may be positive as well as negative in specific geo-historical contexts'. Indeed, in her 2005 study, she found that neoliberal reregulation of drinking and environmental water quality in England and Wales delivered some positive outcomes for communities and the environment. This largely occurred because as citizens were reframed as consumers, and the environment was also reframed as a user with interests 
to be balanced against the consumers' (Bakker, 2005). In addition, Castree (2008) argues that geographers should develop more nuanced analyses of how neoliberalisms take shape in specific contexts and at various scales.

In a promising response to Castree's call, there is a growing body of political ecology literature that explores the role of the biophysical world in challenging and altering neoliberalisms (see Robbins, 2012). Robbins and Luginbuhl (2007, p. 25) describe water as a 'fugitive resource' that presents real challenges to attempts to enclose it because of its material characteristics and processes. Because of its dynamic characteristics, a large amount of political ecology literature that explores governance changes focuses on water (Bakker, 2003, 2005, 2007; Budds, 2009; Ekers \& Loftus, 2008; Harris, 2009; Kaika, 2006). Indeed many parts of the biophysical world play an active role in forcing neoliberalisms to their limits. For instance, a number of political ecologists have incorporated poststructuralist and feminist approaches and explored how human emotions elicited by interactions with nonhumans trouble neoliberal ideas of the rational, entrepreneurial neoliberal subject, therefore complicating the neoliberalisation of nature itself (Anderson, 1995; Sultana, 2011). Others, particularly Indigenous geographers, have highlighted how neoliberalisms offer limited accounts of how nature is valued (Howitt \& Hillman, 2010; Young \& Keil, 2005). Conflicts over the expansion of neoliberal policies into environmental management have resulted in some of the most clear examples of opposition to neoliberal extension (Harris, 2009). These clashes between how nature is understood and valued have highlighted the central role of the state in propelling neoliberalisms and protecting economic growth in spite of disagreement and resistance (Castree, 2010).

These diverse emergent political ecologies reflect recent thinking about neoliberalisms more broadly, recognising the instability of neoliberalising processes and identifying the biophysical world as throwing up specific challenges and opportunities (Lewis, 2009). As such, examinations of the neoliberalisation of nature provide hopeful examples of how space can be produced differently, and politics transformed (Springer, 2012a). Yet the plurality of neoliberalisms and the multiple ways they are experienced illustrate the need for situated case studies of neoliberalising natures (Castree, 2008). In order to contribute to explorations of neoliberalisms, nature and hopeful possibilities, I examine the reregulation and changed governance of freshwater in Canterbury, focusing particularly on the significant work required to extend neoliberalisms to nature, as well as the ways 
this work is troubled, resisted and reworked by subjectivities as well as the biophysical world. Before turning to the ways that neoliberalisms have been resisted and reworked, however, I chart the reregulation of nature throughout a period of rapid reform in Aotearoa New Zealand, before analysing how the revised regulatory framework has been navigated in the Canterbury region as pressures for freshwater access have ballooned.

\subsection{The work of neoliberal environmental governance in} Aotearoa New Zealand

\subsubsection{Environmental reform in Aotearoa New Zealand}

During the 1970s and early 1980s environmental management in Aotearoa New Zealand was largely nationally centralised and intricately bound up with social welfare (Wheen, 2002). Approaches to the environment were based on the understanding that 'nationstate, economy, and society were coterminous' (Larner, 1998, p. 603). Government-led "think big" projects saw significant investment into public works projects, notably large hydroelectric dams, which were intended to secure the energy needs of Aotearoa New Zealanders, particularly in the face of the oil shocks throughout the 1970s, and provide employment. However, this economic model began to falter; by 1984 the number of unemployed working age people had risen to just over three percent, external debt rapidly mounted, and the economy stagnated (Kelsey, 1995; Kelsey, 1997).

In 1984 a liberal democratic Labour government was elected. Although the party was riven by contrasting social democratic and neoclassical economic perspectives, they embarked on broadly neoliberal reforms that dramatically reshaped the political, economic and social landscapes (Kelsey, 1995). Their programme of action was largely based around a critique of state interventionism and led to corporatisation and privatisation of state assets, and economic liberalisation as agricultural subsidies were discarded and price and wage controls removed. As the effects of this initial phase of neoliberal reregulation were beginning to be realised, a conservative National government was elected in 1990. This government set about extending neoliberal reforms through more punitive means, in particular targeting social policy and employment conditions and 'constituting a new political rationality' that remade economic governance (Larner, 1998, p. 604). In spite of significant unemployment, access to social welfare was cut. Between 1987 and 1992 
unemployment rose by $4.9 \%$ for Pākehā, $15 \%$ for Māori and $22.7 \%$ for Pacifika, thus representing the uneven way neoliberalism was experienced (Kelsey, 1995). The cuts to benefit eligibility and rates were designed to encourage beneficiaries to 'self-help' into work (Kelsey, 1995). In addition, employment regulation undermined the place of unions and collectivism in industrial relations, and user pays schemes were introduced to education and health (Barnett \& Pauling, 2005). The policies of the late 1980s and early 1990s created lasting and significant social inequalities in Aotearoa New Zealand (Boston et al., 1999). The dramatic remaking of the relationship between state and citizen has been internationally recognised for the speed and extent with which it was undertaken (Larner, 1997). Successive governments have continued to work within a broadly neoliberal political rationality, although this has varied significantly according to the government, changing social and economic contexts, and has been reworked at different scales (Larner \& Butler, 2005).

Within the emerging political rationality of the 1980s that favoured the entrepreneurial individual, the critique of state interventionism was extended to environmental regulation and a review of existing policy was commissioned. Local and regional government underwent reform between 1984 and 1988; territorial lines were redrawn according to catchments, and responsibility for resource allocation was devolved in an attempt to increase accountability to the people affected by allocation decisions (Cocklin \& Furuseth, 1994). The resource management law reform project was carried out between 1988 and 1991 and came at time when there was significant growth in environmental movements in Aotearoa New Zealand and increasing calls for greater public participation in decision making (Pawson et al., 1992). Subsequently the review involved an unprecedented level of consultation with the public and interest groups (Robertson, 1993), yet it was also subject to intense lobbying for increased private property rights to enable economic freedoms and counter the inefficiencies of the centralised town and country planning model (Memon \& Gleeson, 1995). The influence of lobby groups grew after the general election in 1990 that saw the National Party enter government, and as a result some environmental protections were diluted (Grundy \& Gleeson, 1996).

The Resource Management Act (RMA) that passed into law in 1991 replaced in whole or part close to sixty Acts. The core purpose of the Act was to promote sustainable management, defined as: 
managing the use, development, and protection of natural and physical resources in a way, or at a rate, which enables people and communities to provide for their social, economic, and cultural wellbeing and for their health and safety while -

a) Sustaining the potential of natural and physical resources (excluding minerals) to meet the reasonably foreseeable needs of future generations; and

b) Safeguarding the life-supporting capacity of air, water, soil, and ecosystems; and

c) Avoiding, remedying, or mitigating any adverse effects of activities on the environment (section 5, New Zealand Government, 1991).

At the time, the legislation was viewed as progressive comparative to other states in its goal of promoting sustainable management, in considering the needs of future generations, and its efforts to address the complexity of environmental issues (Grundy \& Gleeson, 1996; Robertson, 1996). The reforms were intended to contrast with the perceived 'restrictiveness and ineffectiveness of regulation and intervention', in order to cultivate greater flexibility and innovation (Robertson, 1996, p. 213), and to rework the 'uncoordinated range' of environmental legislation that had emerged throughout the $20^{\text {th }}$ century (Robertson, 1993, p. 303). As a result, the Act significantly reformed environmental planning practice, and signalled the end of town and country interventionism that had sought to manage the distortions of a capitalist economy (see Memon \& Gleeson, 1995 for a discussion of the changes to planning paradigms in Aotearoa New Zealand). The new legislation was designed to address the effects of activities, rather than regulating the activities themselves.

In the years after it was passed, the RMA was characterised as combining influences of contemporaneous neoliberal reforms with a 'strong environmental ethic' (Cocklin \& Furuseth, 1994, p. 466; Moran et al., 1992). Memon and Gleeson (1995) state that the central objective of promoting sustainable management is indicative of attempts to balance these interests. Early drafts of the RMA were heavily influenced by the Brundtland Report 1987 which defined and set the policy agenda for sustainable development. However, the definition of sustainability in the Act was changed five times after the bill was first introduced and ultimately fell short in addressing the concerns articulated by the Brundtland Report (Pawson et al., 1992). The final definition has been critiqued for failing 
to give precedence to the environment (Memon \& Gleeson, 1995) and because it has subsequently been weakened by the courts who have favoured quantifiable development interests over qualitative intrinsic, cultural and amenity values (Wheen, 2002). Furthermore, Pearce and Kingham (2008) argue that because the RMA was developed within a context dominated by neoliberal discourses, market based allocation was prioritised, and the technocratic approach to the environment has failed to address social equity and protect community access to the environment. Despite these issues of social equity, the RMA has been recognised for its explicit reference to Māori values and for beginning to address the need for Māori to be involved in decision making about the environment (Cocklin \& Blunden, 1998).

Importantly, Cocklin and Furuseth (1994) have argued that the emphasis on mitigating the effects of behaviour, rather than controlling the behaviour itself, reflect a neoliberal privileging of private property rights. This is particularly problematic given the inability to deal with cumulative effects under the legislation (Oram, 2007). Instead of prescriptive legislation, councils are expected to develop their own natural resource plans and policy statements, reflecting the scope for innovation for local conditions in the RMA (Cocklin \& Blunden, 1998). However, territorial authorities were allocated insufficient control over resources and political capability to develop effective plans (Memon \& Kirk, 2012; Moran et al., 1992). Memon and Skelton (2007, p. 255) state that when responsibility for freshwater was devolved, political authorities lacked 'organisational capacity, resources, and information' which had a negative impact on councils. Furthermore, councils were directed by central government to limit their intervention and instead utilise market tools for resource allocation (Memon \& Skelton, 2007). Subsequently, Memon and Weber (2010) argue that within the neoliberal political terrain central government has failed to offer the support and guidance needed to move beyond an effects-based focus, to more integrated approaches to environmental management. Access to water has largely been determined according to 'first-in-time, first-in-right'; that is, the first water use consent application is granted use rights, regardless of whether the application best fulfils environmental, social, cultural and economic values (Memon \& Skelton, 2007). In addition, regional councils have tended to readily renew consents in order to meet users' needs for reliability in their investments (Memon \& Skelton, 2007). Furthermore, regional councils have often interpreted sustainable management in a narrow way, and do not offer long term visions for water allocation (Memon \& Skelton, 2007). These trends in regional 
council management of water leave authorities poorly equipped to address cumulative impacts of water allocation.

While the environment was certainly valued for its ability to generate economic and social security prior to the RMA (Barnett \& Pauling, 2005), within the neoliberal political rationality, this instrumentalist way of relating to nature was subtly reworked by the emphasis placed on private property rights. As a result, there has been a decline in many environmental measures, particularly freshwater health in some regions (Memon, 1997; Ministry for the Environment, 2013b). Indeed, Memon and Kirk (2012) argue that the central political purpose of the RMA has been to curtail environmental regulation to facilitate increased agricultural export earnings, an aim that has proven particularly successful in the Canterbury region.

\subsubsection{The ECan Act - reregulating for the accelerated enclosure of nature}

Throughout the 2000s, Canterbury Regional Council (also known as Environment Canterbury, shortened to ECan) experienced severe problems managing cumulative impacts in a rapidly changing, water hungry agricultural terrain (Memon \& Weber, 2010). In the face of growing pollution of freshwater, pressure to access water for agricultural irrigation and stress caused by piecemeal allocation of consents (often for a 35 year period), the regional elections in 2007 returned a record number of councillors associated with environmental groups and causes. In particular four of the 14 successful candidates campaigned on the basis of protecting water bodies or improving water quality (Burke, 2013). What followed in the next three years was significant progress in the council's performance in improving air quality (a persistent issue in Christchurch) and public transport, but the council was subject to repeated claims that it was slow to process water take consents (Hutching, 2010) and did not have a natural resources regional plan to provide clearer regulation. In 2009 mayors from the city and district councils in Canterbury wrote to the Minister for Local Government criticising ECan's performance, and particularly for failing to adequately lead water initiatives (Environment Canterbury, 2009). At that time, there were a number of large scale water storage proposals that were subject to increasingly tense public debate and costly litigation.

In addition there were existing and proposed Water Conservation Orders that were understood by the Ministry for Agriculture and Forestry as obstacles to developing 
irrigation potential in Canterbury (Ministry for Agriculture and Forestry, 2009). Water Conservation Orders (WCOs), first created in a 1981 amendment to the Water and Soil Conservation Act, and later incorporated in the RMA, protect outstanding 'amenity or intrinsic values' of water bodies. These values are (generally) outside capitalist imperatives for accumulation, and recognising and protecting these values represents an obstacle to the neoliberal reregulation of nature. In an email ${ }^{15}$ to the Prime Minister on 4 September 2009, David Carter, then Minister of Agriculture and Forestry, ${ }^{16}$ and Gerry Brownlee, the Minister of Economic Development, listed the government's options for 'accelerating progress' for two companies that had developed schemes aimed at increasing irrigation supply. Arguing that an existing WCO on the Rakaia River and applications for a WCO on the Hurunui acted as barriers to economic development, Ministers Carter and Brownlee recommended legislative intervention. In a report by the Treasury dated 6 October 2009, WCOs were identified as an issue for water management in Canterbury particularly because they do not consider 'economic or social objectives' (The Treasury, 2009, p. 6). These barriers were perceived as a constraint to 'investment certainty in Canterbury's rural economy' (Ministry for Agriculture and Forestry, 2009, p. 2).

In November of 2009 the central government, critical of ECan's slow consent processing times, and seeking ways to circumvent WCO barriers, commissioned four men to investigate the governance and policy processes of ECan using provisions of both the Resource Management Act and Local Government Act. While the review was underway, the Ministry for Agriculture and Forestry (MAF) recommended to Minister Carter that government intervention in Canterbury's WCOs could take the shape of expanded government powers to review and recommend changes to the Rakaia WCO and halt the Hurunui process. Additionally, they recommended enabling greater intervention powers for the Minister for the Environment to appoint commissioners to herald these changes to the WCOs.

\footnotetext{
${ }^{15}$ Much of the following information was obtained from communications released under the Official Information Act to Chris Todd, South Island Conservation Manager for Forest and Bird, and to Bryce Johnson, Chief Executive of New Zealand Fish and Game Council.

${ }^{16}$ The Ministry for Agriculture and Forestry was incorporated into the newly established Ministry for Primary Industries in 2012. Where examining to events prior to this merger, I refer to the Ministry for Agriculture and Forestry,
} 
In February 2010, the review group, headed by former Deputy Prime Minister in the Fourth National Government Wyatt Creech, reported their findings, and recommended sacking the elected regional councillors based on ECan's poor water management record. The government hastily adopted these recommendations, passing the Environment Canterbury (Temporary Commissioners and Improved Water Management) Act under urgency ${ }^{17}$ on 31 March. The legislation fired the 14 elected ECan councillors ${ }^{18}$ and replaced them with seven commissioners, appointed for their expertise, and also made a number of amendments to how the RMA is applied. Until new regional elections are called, section 31 of the ECan Act grants the Minister for the Environment the power to decide when the RMA applies in Canterbury (Brower, 2010a, 2010b). Further, proposed changes to regional plans cannot be appealed to the Environment Court. These amendments have been labelled unconstitutional by Joseph (2010) because the law is not general in operation so people do not have equal protection under the law, the Act is retrospective, and it constrains access to the courts.

However, Joseph (2010) is most critical of the unexpected changes to WCOs that went beyond the scope of the Creech review recommendations. Significantly the purpose of WCOs in Canterbury were altered - decisions about WCO applications now must give regard to the purpose of the Canterbury Water Management Strategy (see Chapter 4 for a discussion of the CWMS) which gives explicit regard to enabling economic gains (Rennie, 2010). Economic considerations therefore form part of the criteria for decisions about WCO applications in Canterbury, where no such considerations were required before, or are required outside ECan's boundaries. Sections 46 to 61 of the ECan Act suspended Part 9 of the RMA, which relates to WCO processes. The implications of this are the removal of Environment Court jurisdiction over WCOs in Canterbury, and the WCO application hearing body is changed from a special tribunal to the appointed ECan commissioners (or

\footnotetext{
${ }^{17}$ When introduced under urgency, bills are passed through all three readings in a single Parliamentary sitting. This severely limits opportunities for public engagement and discussion, and the tendency of the Fifth National Government to use urgency has been a growing concern (Joseph, 2010).

${ }^{18}$ There are provisions in both the Local Government Act and the RMA under which councillors can be fired, but Cabinet papers show the Minister for the Environment wasn't certain that the situation in Canterbury would meet the standards required to deploy these provisions. Therefore a new law, the ECan Act, was required to circumvent these requirements and provide new commissioners with adequate powers (Brower, 2010b; Officer of the Minister for the Environment, 2010).
} 
person or committee delegated by the commissioners). These changes were also applied retrospectively and so after years of applications, submissions and hearings, the case for a WCO over the Hurunui was interrupted, a month before it was due to be heard by the Environment Court. Joseph (2010) questions the explicit reference the ECan Act makes to the Hurunui WCO process. He states, the 'Hurunui WCO application (or any other WCO application) is unrelated to the statutory purpose. The Act was passed under urgency to rectify systemic governance issues affecting water allocation in the Canterbury region ... Regional councils, however, have no role in deciding WCOs' (Joseph, 2010, p. 194). This extraordinary deployment of legislative power was made possible by Aotearoa New Zealand's unicameral systems - there are few checks on the executive. Weeks after the ECan Act was passed the Minister of Agriculture and Forestry put all regional councils on notice at an irrigation industry conference, stating 'I would have thought what happened recently would be a signal to all regional councillors to work a bit more constructively with their farmer stakeholders' (quoted in Burke, 2013). Minister Carter reveals in this statement the willingness of government to work in the interests of the landholding elites, and therefore exert significant control over the 'fortunes of people and places' (Purcell, 2009, p. 144).

\subsubsection{Making sense of the ECan Act - extending the state of exception}

It is evident in the actions of the government and communication from late 2009 between relevant ministers that the rationality of the ECan Act was to facilitate broadly neoliberal ends - the accelerated enclosure of water in Canterbury in order to increase economic growth. In addition to attempts to shift ways of valuing nature, the ECan Act represents a 'complex reconstitution of state/economy relations in which state institutions are actively mobilized' to provide the political technologies to propel the free market into spaces of environmental management (Brenner \& Theodore, 2007, p. 154). This reconstitution isn't the act of a singular state but emanates from the multiple relations between individuals and groups who shared the desire the achieve economic growth through irrigation (Fontana \& Bertani, 2003). This was clear in the 2009 email from Ministers Carter and Brownlee referenced above; they were not concerned just with general economic development, but the progress of two specific companies, TrustPower (seeking changes to the Rakaia WCO) and the Hurunui Water Project Ltd. Through relations that knotted around neoliberalism, the government, industry, the landowning elite that have long 
influenced environmental management in Canterbury (Memon \& Weber, 2008), and the district councils that lobbied for ECan councillors to be sacked, actors were able to deploy their networked power through legislative change and forge new 'power geometries' (Massey, 1993). The new power geometries re-placed the ways groups were able to act within state/economy relations - the interests of the irrigation and agri-food industries and landowners were extended through the intensified process of alienating people from the river commons and facilitating accelerated enclosure of water. The economic interests of these groups were progressed through attempts to manage the way people relate to the material world. Water could more easily be enclosed in a 'timely manner' (Ministry for Agriculture and Forestry, 2009), and used by irrigators at the expense of other interactions with the rivers (kayaking, fishing, gathering food). Here capital accumulation is indicative of the type of violence Springer (2012a) identifies as maintaining unequal hierarchies, both the structural violence of political and economic systems, and symbolic violence, acts and relations of dominance and submission that see citizens lose their freedoms, rights and access to public goods (Gunder \& Mouat, 2002). In this way we can explore how waterscapes are the location and tool through which 'hegemonic struggles' are fought (Ekers \& Loftus, 2008, p. 709).

The government, however, deployed disproportionate and alarming use of legislative power (Brower, 2010a; Joseph, 2010) within this hegemonic struggle in a way that does not fit easily with most existing depictions of neoliberal reform. Peck and Tickell's (2002) characterisation of state roll back and roll out is often used as a frame to understand trends of state involvement in creating favourable conditions for the market. They describe early phases of neoliberalism in which the state deregulated and retreated from many functions as "roll back". This has often been followed by a state "roll out" to consolidate the role of the market in regulating life. At times, roll out requires state authoritarianism to discipline deviant subjectivities that emerged from roll back neoliberalism, using social, employment and penal policies. Even though disciplining these subjectivities has implications for the credibility of liberal-democratic claims to equality (Purcell, 2009), Peck and Tickell's description does not provide the scope to encompass instances of the state encroaching on formal political rights, such as voting and access to justice, in liberal democracies in the name of neoliberal rationalities. Although the roll back/roll out conceptualisations brought to light the active role of statecraft in forging neoliberal futures, in over emphasising the coherence of the neoliberal project Peck and 
Tickell do not provide the analytical tools to address the range of ways that state institutions are mobilised (Lewis, 2009).

To attempt to make sense of the particular configuration of state power and citizenship in Canterbury, it's necessary to turn to radical democrats such as Swyngedouw, Purcell and Žižek. Radical geography literature on democracy has increasingly explored the intersections between formal politics and neoliberalism. To date however, there has been little engagement between this literature and political ecologies that examine the neoliberalisation of nature (however see Swyngedouw, 2009, 2013b). More generally the role of the state remains under conceptualised in political ecology literature (Ioris, 2012). Given that 'neoliberalism is a profoundly biophysical project rather than incidentally so' (Castree, 2011b, p. 47) there are important insights to be made from using both radical democracy and political ecology frames to explore the ongoing reregulation and enclosure of nature.

In 2000 Swyngedouw recognised that state forms were shifting and rescaling in a manner that traditional theories of governance could not account for. He argued that the rescaling of governance that has characterised globalisation 'often takes place through disturbingly undemocratic procedures by an increasingly authoritarian state apparatus' (Swyngedouw, 2000, p. 70). However, Dean (2010) argues that an authoritarian state has always been a part of the neoliberal architecture. A strong state was to be cultivated by elites, while the rest of the population was fed enticing narratives about freedom from state control. The ability to repress the masses was viewed as essential to facilitate market extension and to 'neutralize the pathologies of democracy', such as the influence of interest groups and welfare state demands (Dean, 2010). Agamben (2005) describes such practices of suspending individual democratic rights and extending government powers as a 'state of exception'. This state, in which political adversaries are othered and excluded, has become the 'dominant paradigm of government in contemporary politics' since the World Wars (Agamben, 2005, p. 2). Dean (2010) uses the example of union busting and regulation against workers' rights to evidence the everydayness of the state of exception. Swyngedouw $(2007,2009)$ has recently brought together Agamben's ideas about government powers and democracy, neoliberalisms, and the reregulation of nature. $\mathrm{He}$ argues that people contesting the neoliberal environmental order are often framed as extremists or terrorists and placed outside the law. There is an absence of literature, 
however, that deals with instances where the state of exception is explicitly extended to whole geographical populations to facilitate the enclosure of nature. Given the "normality" of the state of exception, the ECan Act would not indicate a new degree of authoritarianism; rather it is a more overt and audacious version that is expanding its reach to curtail voting rights and access to justice in order to widen the scope of neoliberal governance. While the shortcomings of formal democracy are well documented (Swyngedouw, 2011b), participation in regional elections represents an important avenue to influence the direction of environmental policy. Participation in regional elections has been meaningful, as was evident in Canterbury in 2007 when candidates successfully campaigned on issues of freshwater access and quality.

In late 2012 the suspension of voting rights was extended by for a further three years until 2016. The extension was publicly justified on the basis that the appointed commissioners were able to provide a technocratic, non-political solution to Canterbury's water problems. The Minister for the Environment, Amy Adams, stated:

The Canterbury region has significant economic growth potential but also faces significant challenges. It is critical for New Zealand that the planning governance structure for Environment Canterbury is stable, effective and efficient. To keep the freshwater management work on track, we intend to retain the limited appeal rights on decisions made by Environment Canterbury on plans and policy statements relating to freshwater management (Adams, quoted in Cairns, 2012).

Adams' claims that the further suspension of the formal rights of democracy are 'critical' for successful water management reflects 'growth-oriented development practices [that] provide less of a solution to environmental problems, and more of a means to sustain ... particular socioenvironmental transformations' (Kaika, 2006, p. 169, emphasis in original). For Adams, keeping water management on track requires apolitical, expert commissioners and limited access to judicial review (Purcell, 2009). The threat of economic ruin and promise of 'stable, effective and efficient' environmental management sustains the neoliberal discourse of inevitability, that the only way of organising our economy (and society) is according to neoliberal principles, and the alternative is ruin (St. Martin, 2005; Swyngedouw, 2011b). The ECan Act and extended period without formal democracy represent an attempt to forcibly 'align social and ethical life with economic criteria and expectations' (Vrasti, 2011). 
Minister Adams' quote above was reinforced by the CEO of Irrigation NZ, who commended the government for '[r]eplacing politically motivated, tradeoff focused councillors ... with independent and rational thinkers' (Curtis, 2013). Curtis' comment is emblematic of the technocratic managerialism that characterises the depoliticised and 'consensual times we are currently living in' (Swyngedouw, 2013b, p. 5). As the economy and politics are increasing constructed as ontologically separate, managers, experts and consultants are privileged as the most appropriate people to facilitate market extension (Swyngedouw, 2011b). Žižek (2008, p. 40, emphasis in original) states that '[t]oday's predominant mode of politics is post-political bio-politics'. For Žižek, drawing on Rancière and Agamben, post-politics is a mode of politics that privileges technocratic expertise that is "objective" and portrayed as beyond ideology. Post-politics is entangled with biopolitics, a derivation of Foucault's biopower. Biopower is conceptualised as an attempt to 'bring regularity and equilibrium to both lives in themselves, and to the general social order' (Ekers \& Loftus, 2008, p. 706). Foucault (1990) contends that securing docility has been vital to the progression of capitalism. Complementary to neoliberal state authoritarianism, post-political bio-politics is a mode of rule focussed on regulating for the bare functions of human life, and is therefore rendered as beyond the scope of political contestation.

Within such a politics, the environment is reduced to an object to be managed, rather than a domain constituted by lively "things" that are enrolled into multiple relations (Swyngedouw, 2013b). Many of these relations are tied to neoliberal rationalities that produce environmental change. For instance, freshwater is a fundamental component of how the dairy industry participates in domestic and global markets. Yet the resulting impacts on freshwater quality and access are very rarely linked in political discourses to the neoliberal drive for constant economic growth. Instead dominant discourses privilege mitigation (as prescribed by the RMA's effects based approach) achieved through technocratic management, which enables this growth to be sustained, despite the violent impacts on the environment. In Canterbury, as per Agamben's description of the state of exception, the government extended its powers through their appointment of technocratic ECan commissioners and reduced public access to the courts, an important space to question the neoliberal logics informing environmental management. In this way, government worked to produce a post-political bio-politics, in the sense that they worked to render decisions beyond politics. This was done in two ways - by dramatically 
constraining public space for dissensus, and by deploying neoliberal discourses of inevitability that characterised reregulation as a necessary function to provide for the bare minimum of human life (Swyngedouw, 2009). The work to cultivate a post-politics in Canterbury will be further explored in Chapter 4 . These post-politicising processes were hastened and simultaneously made apparent by a state of exception that was designed to reregulate the waterscape to more readily serve neoliberalisations of nature.

\subsubsection{Caring capitalism and inevitable neoliberalisms?}

For many people free market extension is seen as desirable as there are multiple appealing aspects of neoliberal rationality (Larner, 2003). For these subjectivities enclosing nature is not productive of social violence but social stability. For the Mayor of the Hurunui District, damming rivers in the area was seen to be an important means for improving the health of his community:

[D]uring the ' 98 ' 99 drought, the local medical centres were inundated with people under severe stress, families ... [M]y wife, was doing quite a lot of school teaching ... the stress of the parents was exhibited in the behaviour of the children at school because the families were, there was tension at home because of the droughts, financial pressures that come out of that and then there's the marital problems that come out of that sort of tension, then it's relayed to the children and then it's exhibited in behaviour of kids at school and the medical professionals were dealing with that, the educational professionals dealing with that sort of thing. And it was very clear to see that if an irrigation scheme, for example, took some of that stress out of the community then it'd be a much happier and healthier community because ... stress and health go hand and hand. Health ... physically, spiritually, mentally and everything else, they're all linked. So there was all those things there and people like [the chair of the Hurunui Water Project], I mean it's not all about irrigation to make more dollars, it's, you know, he has the community at heart as I do. And it's about that healthy community, not just in a physical sense, that is as important as a healthy bank balance. There's all that that I think we struggle to get the outside [people] to accept and understand. For them it was just about dirty dairying and making more money, end of story. That's what they thought the driver of irrigation is. Well clearly there are people with their heads in that space 
but a community like ours, it's clearly not the driver, the main driver (Donald 21 February 2012).

Here the participant recounts his trust in 'caring capitalism' (Vrasti, 2011). Caring capitalism offers the promise of conditions that enable dynamic entrepreneurialism that serve the interests of the community. Introducing technologies to hasten the enclosure of water resources was done with the promise of economic growth and trickle down wealth creation (Curtis, 2013), promises that speak to the heart of what makes neoliberalisms enjoyable for people, something they become emotionally invested in, in spite of its violence (Vrasti, 2011). The appeal of neoliberal growth for the Hurunui District will be further detailed and explored in Chapter 5.

As well as trusting caring capitalism, the mayor also reveals discursive constructions of neoliberalism and economic growth as inevitable and necessary to sustain the community. This inevitability justifies a certain degree of violence as "there is no alternative"; numerous concessions can and should be made to neoliberalisms. And yet, geographers have argued that neoliberalism is 'merely hegemonic now' (Purcell, 2009, p. 144) - there are already existing alternatives, as well as multiple alternatives that are yet to come into being, and it is inevitable that they will unsettle neoliberal hegemony. As with GibsonGraham's (2006, p. 49) case study of the Latrobe Valley, things could have been different, 'other economies could have been installed ... economic development is not a lawful natural process but one in which (in this case) economic "laws" were invoked politically'. Neoliberal hegemony has resulted in many people accepting the economy as apolitical, and as prescribing certain courses of action. As Gibson-Graham (2006, p. 56) claim, '[t]his ideological fantasy has become safe and even enjoyable, directing and limiting politics to certain channels, blinding us without realising it to the possibility of other options'.

Despite the appeal of the neoliberal fantasy, and despite post-politicising processes, people contested the new institutional framework that protected and extended the power of elites, and sought to express their citizenship in other ways (Swyngedouw, 2000). Efforts to facilitate the neoliberalisation of nature had cut too far into the cultural meshwork of Canterbury, suspending the tools through which people exercised their citizenship in the region (Perreault, 2006). On 13 June 2010, in the middle of a cold Canterbury winter, around 3,000 people gathered in protest in the central city, momentarily forging a space for public dissensus. According to one report it was the 
largest rally ever held in the public Cathedral Square (Finnie, 2010). Together people built a cairn, filled with river stones, to remain in the square until democracy was returned to the region, demands disregarded by the government's extension of the commissioners' term. The persistent limitations to democracy and justice were made easier by two large earthquakes in Canterbury in September 2010 and February 2011. Both events caused significant damage and the latter quake resulted in the loss of 185 lives. People in the region have faced multiple challenges arising from the earthquakes, including further overt expressions of the state of exception through the Canterbury Earthquake Recovery Act (see Hayward, 2012). In March 2013 a small group attempted to lay a wreath at the cairn. The area where the cairn lies has been cordoned off since the earthquake as buildings are demolished and new buildings constructed. The morning of the planned wreath laying, the Canterbury Earthquake Recovery Authority revoked permission for the group to enter the cordoned area because the wreath laying was deemed to be a political event (Radio New Zealand, 2013a). The regulation under which this decision was made is unclear. For some people, the material and emotional hardships of the seismic events have consumed energy that would have otherwise been used to contest state reregulation (Joanne 5 November 2011). In response to freshwater reregulation and later interference of ECan commissioners in collaborative processes (described in Chapter 4), one participant stated 'we should be rioting in the streets but can Christchurch riot any longer? We can't. We're stuffed, we're earthquake stuffed' (Louis 31 October 2011). Nature's refusal to be contained, and the government's opportunistic response, has meant that people have had to 'live with' the free market extension gained via extraordinary means (Castree, 2010).

\subsection{Conclusions}

In this chapter I have reviewed existing geography literature about neoliberalisms and explored neoliberal approaches to governance in Aotearoa New Zealand, particularly through charting change to environmental regulation. The RMA, developed within a rapidly reforming context, was initially seen as an attempt to reconcile both neoliberal interests (particularly securing increased property rights) and environmental concerns. The application of this legislation has proven to be complicated however, as territorial authorities have not been adequately supported by central governments to move beyond effects based management (Memon \& Weber, 2010). Perhaps nowhere was this more 
obvious than the increasing pressures on freshwater access and quality in Canterbury. Within this context the national government sought to overhaul freshwater management. Yet the reforms implemented were designed primarily to ensure economic growth through capital accumulation by the agri-food industry. In justifying the suspension of formal democratic rights, government and industry representatives have deployed discursive framings of neoliberalisms as inevitable and desirable (Cairns, 2012; Curtis, 2013). The ECan Act 2010 represents an unprecedented move to provide political technologies to facilitate the weakening of freshwater protection tools and hasten the enclosure of lakes and rivers.

Combined, the curtailment of formal democratic rights, discourses of inevitability, and shift of environmental decision making to technocratic managers are indicative of postpoliticising processes that occur through a state of exception. Although Dean (2010) argues that the state of exception is a "normal" part of our everyday lives, the reregulation of water management in Canterbury represents a particularly overt encroachment on individual democratic rights. Nairn and Higgins (2007) caution against overemphasising the power of elites and governments in creating and sustaining neoliberalism, yet the manner in which central government and agri-food industry deployed political and economic power is alarming. The existing literature examining neoliberalisms offers limited accounts of how states of exception have been used to facilitate the enclosure of nature. While poststructuralists have warned against eagerness to name processes as neoliberal, radical democracy theorists offer geographers a range of conceptual tools that help to make sense of actions by the state that actively work to reconstitute political space and subjectivities. In Canterbury, the governments' willingness to do away with voting rights and limit access to judicial review indicates a readiness to do the work required to maintain the inequalities neoliberalism has produced. Identifying these processes as undemocratic and as operationalised within a neoliberal rationality is essential to fostering counter hegemonic processes that challenge neoliberalisms (Purcell, 2009). 


\section{Post-politicising processes in environmental governance - collaboration and consensus in the Hurunui Waiau catchment}

\subsection{Introduction}

Since the 1990s environmental governance in western contexts has been increasingly characterised by devolution, based on the promise of enhanced local democracy (Ribot, 2006). This trend towards local collaboration and deliberation has developed out of questions about formal, state-centric democracy and the place of ideology in decision making (Mouffe, 2005). Yet the realities of devolution have been complicated and have not necessarily strengthened democracy (Leach et al., 2007; Memon \& Kirk, 2012; Ribot, 2006). Indeed claims have been made that deliberative processes provide an effective means to maintain neoliberal hegemony because resistance is enrolled into outwardly democratic processes and effectively silenced (Gunder, 2010; Ramsey, 2008). According to these critiques collaborative approaches are, therefore, unable to contest neoliberal dominance (Purcell, 2009). Furthermore, radical democratic literature has argued that collaborative and consensus based planning have aided post-politicising processes that channel outcomes that fit with neoliberalisms (Swyngedouw, 2007). However, despite increasingly devolved environmental governance, and simultaneous post-politicising processes that constrain access to environmental decision making (Page \& Bakker, 2005), there is little empirical work that draws on radical democratic theory to explore these processes. 
In order to address this gap, this chapter will examine an example of collaborative decision making about freshwater in Canterbury. As discussed in the preceding chapter, the ECan Act produced a significant democratic deficit as formal democratic tools were suspended. This intervention by central government raised the prospect of public protest and resistance, and as a result, government recognised a need to 'capture the banner of democracy' (Purcell, 2009, p. 146). In this context, central and regional government endorsed the Canterbury Water Management Strategy (CWMS), a framework that was designed to change the adversarial nature of water politics. Established in 2010 under the CWMS framework, the Hurunui Waiau Zone Committee (HWZC) was directed to collaborate and reach consensus on how to achieve nine measurable outcome targets, one of which was irrigated land. The appointed Committee worked intensively over a 12 month period to develop a programme of action.

Throughout this chapter, I explore how consensus and collaboration were enrolled into the process of post-politicisation. In particular I focus on the way power remained unaddressed in a way that worked to consolidate particular environmental rationalities (Bridge \& Perreault, 2009). However, this chapter will also explore the ways these rationalities were contested and complicated. Critiques of post-political theories have questioned the totalising effects of this approach, in particular its dismissiveness of everyday practices of resistance (Featherstone, 2013; McCarthy, 2013). The moments and processes that troubled dominant constructions of nature within the HWZC space point to the nuanced ways that post-politicisation is negotiated, contested and reworked.

\subsection{Changing conceptions of democracy - political ideology, power, and post-politics}

In the late $20^{\text {th }}$ century, a number of sociologists began to argue that as a side effect of modernity some traditional institutions were becoming irrelevant (Mouffe, 2005). At the same time political theorists were pointing to plummeting voter turnout as indicative of the inadequacies of existing formal democracy (see Habermas, 1975). This declining voter turnout was seen to be the result of increasing public dissatisfaction with ideological party politics. Questions about the place of ideology within democracy intensified as communist states collapsed (Huntington, 1993) and the 'end of history' was declared (Fukuyama, 1992). According to Fukuyama (1992), capitalism had prevailed and therefore humans had 
reached the extent of ideological evolution. Extending these claims about the irrelevance of political ideology, Beck (1996) and Giddens (1994) argued that individualism and globalisation had undermined collective identities and social capital, and therefore, strong democracy (also Putnam, 2001). In response to these changes, Giddens (1998) articulated ideas about a "third way", advocating a politics that moves beyond divisions of left and right, which are dismissed as irrelevant. Instead the third way offers visions of a reworked state that has retreated somewhat in order to enable communities to take greater selfresponsibility, resonating with neoliberal reconceptualisations of the relationship between state and citizen (Leach et al., 2007; see Chapter 5). Since political ideology was disregarded, community decision-making would instead be defined by its position beyond politics, characterised instead by morality and values (Rose, 2000). Through communities, decisions would be made in partnerships that stretched beyond levels of government, and represented a move towards governance (Ribot, 2006; Walters, 2004). Governance has been conceptualised as a form of rule based on self-management and partnership, operating within, and operationalised by, increasingly complex social, political and economic relations (Walters, 2004).

Within third way governance discourses, and assertions of a crisis of formal democracy, collaborative forms of governance have been increasingly deployed to enrol individuals and communities into environmental decision making (Agrawal, 2005; Mehta et al., 2001). Ribot (2006, p. 115), drawing on earlier work (Agrawal \& Ribot, 1999), argues that decentralised governance is predicated on proximity and democratic processes reducing transaction costs, producing better downward accountability of decision makers, and enabling decision makers to match decisions and resources to local needs and aspirations'. Many examples of devolved, deliberative governance arrangements are designed according to Habermasian communicative planning theory. Jürgen Habermas advocates a form of decision making whereby participants should communicate what they believe using rational arguments and aim to create understanding (Purcell, 2009). Ideally the process through which this understanding is developed requires honesty and empathy from participants as well as a willingness to work for the common good. The process should neutralise power relations, be accessible for all those affected by the decision, and enable equal opportunities for people to participate (Purcell, 2009). Innes and Booher (2004, p. 428) describe the ideal situation as one in which 'an inclusive set of citizens can engage in authentic dialogue where all are equally empowered and informed and where 
they listen and are heard respectfully and when they are working on a task of interest to all'. The result of this ideal situation would be a forum in which multiple forms of knowledge are empowered and consensus decisions are reached. For Habermas (1987, p. 315) communicative action is a 'noncoercively unifying, consensus-building force of a discourse in which the participants overcome their at first subjectively biased views in favour of a rationally motivated agreement'. While communicative planning is enacted in a range of ways, a number of theorists have illustrated some of the positive dimensions of such an approach (Ghose, 2005). For instance, Innes and Booher (2004) provide examples of successful communicative planning, pointing to instances of improved social capital, cooperation to design rules in a contentious situation and joint learning that led to consensus. Bond and Thompson-Fawcett (2007) state that there are significant intangible benefits, such as social learning, that result from devolved decision making. Others have argued that enacting citizenship at a more local level can provide important opportunities for people, especially marginalised groups, to claim a degree of voice in policy processes (Brownlow, 2011; Ghose, 2005; Purcell, 2009). However, Habermas acknowledged that the ideal situation he prescribed was probably unattainable (Purcell, 2009). As Hillier (2003, p. 42) points out '[i]n reality, actors may see little benefit in behaving 'communicatively rationally' when strategic, instrumental power-plays and manipulation of information could result in more favourable outcomes for themselves' (also TewdwrJones \& Allmendinger, 1998). As Flyvbjerg (1998) asks, '[w]hy use the force of the better argument when force alone will suffice? Power knows its privilege and knows how to use it.' Indeed, how communicative planning accounts for power and the possibilities for neutralising power relations are central foci of critique.

Foucauldian analyses of communicative planning interrogates the neutrality claimed, and the symbolic violence such claims can exact (Flyvbjerg, 1998). From a Foucauldian perspective 'particular ensembles of power, institutions, language and practices construct issues in certain ways and act on them to produce particular material effects' (Leach et al., 2007, p. 22). Takeda and Røpke (2010) argue that the possibilities for neutralising power within consensus based approaches are constrained by the broader ensembles of structures and relations that the processes are embedded within (see also Ramsey, 2008). These institutional and political structures are firmly situated within dominant knowledge systems. Even when political and economic forms of domination are reduced, internalised notions of who has a right to speak limit possibilities for equal opportunities to speak and 
be heard (Young, 1996). In localising decision-making and situating it within dominant forms of knowledge, communicative planning cannot adequately address 'larger historically and socially constructed structures which pervade communicative processes' (Takeda \& Røpke, 2010, p. 179). Walters (2004, p. 36) contends that reworked governance 'seeks to redefine the political field in terms of a game of assimilation and integration ... [and] imagines a politics of multilevel collective self-management, a politics without enemies'. Such assimilative tendencies and approaches that leave power inequalities unaddressed have, in some instances further marginalised groups with different worldviews (for an overview see Coombes et al., 2012). In working towards a consensus that congeals around dominant forms of knowledge, the possibilities for alternative worldviews to shape the process are constrained (Leach et al., 2007).

Also focusing on questions of power, Purcell (2009) has built a strong critique of the manner in which decentralised authority can be mobilised and manipulated in a variety of ways. In particular, a number of theorists have identified links between collaborative decision making and continuing neoliberal hegemony (Celata \& Sanna, 2012; Ghose, 2005; Harvey, 2005; Purcell, 2009). Despite the development of communicative planning in opposition to neoliberal economics (Tewdwr-Jones \& Allmendinger, 1998), Gunder (2010, p. 303) argues that 'the evidence suggests that collaborative, or communicative planning, has largely been captured, or has simply been intentionally deployed, to obscure and facilitate the dominant ideology of contemporary market forces'. As people, groups and communities are enrolled into collaboration with the promise of conflict resolution, they are diverted from contesting power relations that lead to and sustain marginalisation (Ramsey, 2008). In addition, Marxian influenced analyses argue that because collaborative processes generally happen at a local level, issues become particularised to those places, negating universal demands to fairness that have been traditionally articulated through notions of class (Gunder, 2010). Žižek (1999b) argues that this prevents situations becoming truly political as opposition cannot be effectively consolidated at a wider scale. Through the localisation of decision making, struggle is 'defused, marginalized, or simply outright ignored' (Gunder, 2010, p. 303). As a result of this ability to isolate and ignore demands, collaborative decision making processes have been critiqued for acting as tools to discipline citizens and for suffocating resistance (Ghose, 2005). 
Furthermore, despite the goal of consensus being largely rejected by communicative theorists (Dryzek, 2001), Chantal Mouffe (2000) argues that ongoing attempts to resolve the inherent tensions of liberal democracies through consensus presents a flawed and impossible goal. She claims that traditions of liberalism (based on human rights and individual liberty) and democracy (grounded in equality and popular sovereignty) are fundamentally paradoxical in their aims. Resolving this paradox and eliminating dissensus is impossible as equality and individual freedom are irreconcilable (Mouffe, 2000) and furthermore attempting to reach a resolution is dangerous as the tension and contestation between liberalism and democracy are what make liberal democracies promising. As Mouffe (2000, pp. 10-11) explains, the liberal democratic paradox represents the 'very condition of possibility for a pluralistic form of human coexistence in which rights can exist and be exercised, in which freedom and equality can somehow manage to coexist'. Echoing and reworking planning and political theorists' concerns about the exclusionary effects of consensus building (see, for instance Tewdwr-Jones \& Allmendinger, 1998), Jacques Rancière (cited in Swyngedouw, 2007) claims attempts to reach consensus represent the 'end of politics' as such processes work from the assumption that participants perceive and name things in the same way, and share understandings of what issues are at stake. There is a clear division between what is intelligible and can be heard and understood, and what is unintelligible noise; there is closure around what is legitimate and rational within decision making (Rancière, 2001). Rancière (2001) describes this division of what can and can't be heard, and what is legitimate and rational and what is not, as the partition of the sensible. This partition defines what can and cannot enter political spaces.

In this vein radical democratic theorists such as Rancière, Alain Badiou, Slavoj Žižek and Erik Swyngedouw, a geographer, have examined processes that corrode democratic rights and have led to what is commonly described as post-politics. Specifically, Swyngedouw (2011b) characterises post-democratisation as signified by the increasing governing power held by elites, and passivity from the masses. He contends that consensus politics lead to something resembling the post-politics articulated by Mouffe (2005) and Žižek (1999a). According to these theorists, post-politics is a situation in which political ideology is disavowed and managerialism elevated, conflict is rejected in favour of consensus based decisions that are made based on technical expertise, the universalisation of demands is prevented as decision making is localised, and the socio-political status quo is maintained. 
According to Mouffe $(2000,2005)$, halting post-politicisation requires a rejection of the idea that conflict can be ended through consensus, and renewed attention to how the democratic paradox of liberal democracy is negotiated. She argues that a more worthy focus than conflict resolution would be shaping the nature of the conflict itself.

Within environmental governance, the potential for communicative processes to be carried out in ways that reify dominant forms of knowledge and ignore uneven relations of power are of concern, given that neoliberal processes of privatisation and enclosure also act to constrain public participation (Page \& Bakker, 2005). Accordingly, political ecologists have recently turned their attention to the multiple and changing scales and institutions through which environmental governance takes place (Leach et al., 2007; Peet et al., 2011; Takeda \& Røpke, 2010). Despite the dearth of empirical work exploring collaborative environmental governance through a post-political lens (although see Celata \& Sanna, 2012; and less explicitly Li, 2007), an approach informed by post-politics offers a useful conceptual toolkit to make sense of how neoliberal relations with nature are sustained and progressed and enables an exploration of the broad relations of neoliberalised nature identified in Chapter 3. Furthermore, a post-political analysis rooted in a feminist poststructuralist political ecology tradition offers a framework that can take a more multiscalar, inclusive and nuanced approach to experiences of power and resistance than radical democrats currently offer.

In the remainder of this chapter I draw on these bodies of literature to examine collaborative freshwater governance in Canterbury, and these links will be further extended in Chapter 5. In the following section, I chart how and why collaborative approaches were enrolled in Canterbury, before turning to a detailed examination of the HWZC's efforts to collaborate and reach consensus. To aid the reader, both a timeline of events and a flow chart, illustrating shifting responsibilities between organisations and the development of regulations for the Hurunui Waiau Zone, are included (see Table 2 and Figure 5). I then describe how the Zone Committee process was both indicative of postpoliticising tendencies, while also contesting this trajectory. Much existing radical democratic literature takes a narrow view of what counts as politics (Swyngedouw, 2013b; Žižek, 1999b); this understanding of politics will be explored and critiqued in the latter half of this chapter, and an approach that is more attentive to everyday power relations will be further developed in Chapter 5 . I then conclude by exploring what this case study indicates 
for ongoing debates about the usefulness of collaborative planning models, particularly in relation to questions of power.

Table 2 Timeline of key events and processes

\begin{tabular}{|c|c|}
\hline Date & Events and processes \\
\hline $1997-1998$ & Significant drought in Canterbury \\
\hline $1998-2009$ & $\begin{array}{l}\text { Canterbury Strategic Water Study carried out, and } \\
\text { Canterbury Water Management Strategy developed }\end{array}$ \\
\hline August 2007 & $\begin{array}{l}\text { Application for a Water Conservation Order (WCO) on the } \\
\text { Hurunui River made by the New Zealand and North } \\
\text { Canterbury Fish and Game Councils and the New Zealand } \\
\text { Recreational Canoe Association }\end{array}$ \\
\hline August 2008 & Special tribunal appointed to hear the WCO application \\
\hline August 2009 & $\begin{array}{l}\text { Special tribunal completes its report on the application for } \\
\text { a WCO on Hurunui River and sends it to the Minister for the } \\
\text { Environment }\end{array}$ \\
\hline November 2009 & $\begin{array}{l}\text { Central government commissions an investigation into the } \\
\text { performance of ECan }\end{array}$ \\
\hline 19 February 2010 & Creech report into the performance of ECan is released \\
\hline 31 March 2010 & ECan Act passed under urgency \\
\hline 26 July 2010 & First public meeting of the HWZC \\
\hline 2 August 2010 & $\begin{array}{l}\text { Moratorium placed over the Hurunui River, suspending } \\
\text { consent applications to enable the development of a } \\
\text { regional resources plan }\end{array}$ \\
\hline October 2010 & $\begin{array}{l}\text { Ngāi Tahu revoke support for the Hurunui Water } \\
\text { Conservation Order application }\end{array}$ \\
\hline December 2010 & $\begin{array}{l}\text { The Hurunui Water Conservation Order application is } \\
\text { revoked by Fish and Game Councils and the New Zealand } \\
\text { Recreational Canoe Association }\end{array}$ \\
\hline
\end{tabular}




\begin{tabular}{|c|c|}
\hline & $\begin{array}{l}\text { Moratorium placed over the Waiau River, suspending } \\
\text { consent applications to enable the development of a } \\
\text { regional resources plan }\end{array}$ \\
\hline 22 February 2011 & $\begin{array}{l}\text { A shallow earthquake with a magnitude of } 6.3 \text { occurs in } \\
\text { Canterbury, causing widespread destruction and } 185 \\
\text { deaths }\end{array}$ \\
\hline 29 April 2011 & $\begin{array}{l}\text { Draft ZIP released to the public for consultation. } 125 \\
\text { written submissions are made }\end{array}$ \\
\hline May - June 2011 & $\begin{array}{l}\text { Six additional HWZC community meetings are held around } \\
\text { North Canterbury, and in Christchurch, to discuss the draft } \\
\text { ZIP, as are meetings with interest and industry groups }\end{array}$ \\
\hline 22 July 2011 & $\begin{array}{l}\text { Final HWZC ZIP is released in order to form the basis of a } \\
\text { Proposed Hurunui Waiau Regional Plan (PHWRP) } \\
\text { developed by ECan }\end{array}$ \\
\hline 22 August 2011 & $\begin{array}{l}\text { Public HWZC meeting held in Amberley during which ECan } \\
\text { planners recommend a different approach to nutrient } \\
\text { loading limits to that contained in the ZIP }\end{array}$ \\
\hline 19 September 2011 & $\begin{array}{l}\text { Public HWZC meeting held in Waipara where the impact of } \\
\text { ECan's position on the ZIP was debated }\end{array}$ \\
\hline 1 October 2011 & $\begin{array}{l}\text { Central government imposed moratoria over the Hurunui } \\
\text { and Waiau Rivers expired. The PHWRP is publicly notified } \\
\text { for submissions }\end{array}$ \\
\hline 27 February 2012 & $\begin{array}{l}\text { Submissions on the PHWRP close, with a total of } 162 \\
\text { submissions. Three ECan appointed hearing commissioners } \\
\text { are convened to consider the submissions and evidence } \\
\text { given in support, and to make recommendations to ECan }\end{array}$ \\
\hline $\begin{array}{l}29 \text { October - } 6 \\
\text { December } 2012\end{array}$ & Hearing of submissions on the PHWRP \\
\hline 18 April 2013 & ECan commissioners accept the recommendations of the \\
\hline
\end{tabular}




\begin{tabular}{|l|l|}
\hline May 2013 & $\begin{array}{l}\text { hearing commissioners } \\
\text { appeals to the High Court on points of law relating to parts } \\
\text { of the Hurunui Waiau River Regional Plan }\end{array}$ \\
\hline August 2013 & $\begin{array}{l}\text { The first stage of HWP's Waitohi scheme is granted a } \\
\text { consent by ECan }\end{array}$ \\
\hline September 2013 & $\begin{array}{l}\text { HWP secures \$2.4 million of funding from the Ministry of } \\
\text { Primary Industries for further feasibility studies for the } \\
\text { Waitohi scheme }\end{array}$ \\
\hline
\end{tabular}

\subsection{The Canterbury Water Management Strategy - eliminating conflict and ensuring "more water"}

In late 1997 a significant El Niño weather event developed over the Pacific region. For Aotearoa New Zealand, this manifested into a significant drought on the East Coast which was predicted to cost the country more than NZ\$1 billion, largely from lost agricultural earnings (Basher, 1998). The Canterbury region was particularly affected, and projections indicated that climate change would exacerbate the impacts of similar weather events in the future (Warrick, 2009). As detailed in the previous chapter, there were simultaneous pressures for more freshwater to enable conversion to dairy farms. Consequently a number of proposals for large scale water storage were developed, and were highly contested.

Due to these pressures on freshwater, and perceptions of poor management, individuals from the Ministry of Agriculture and Forestry and Ministry for the Environment initiated a study of freshwater resources in Canterbury. The study (stage one of the Canterbury Strategic Water Study, see Table 3) recommended water storage to meet future demands. As water conflicts became protracted in the years following the drought, and the public became progressively frustrated with water politics (Gorman, 2009), a Mayoral Forum consisting of the mayors and CEOs of the 11 local authorities drove the following stages of the Canterbury Strategic Water Study. The Mayoral Forum appointed a steering group, 
members of which were chosen based on their expertise and who they were representative of. The steering group developed much of the CWMS and reported to the Forum (Canterbury Water, 2010). Over several years the Forum and the steering group worked outside the statutory boundaries of the Resource Management Act (RMA), viewing the processes established under the legislation as 'adversarial, costly and time consuming' (Lomax et al., 2010, p. 3). Initially the focus was predominantly on water storage options, and efforts to intensify land use (Chris 12 August 2010; Lomax et al., 2010). It wasn't until 2007 that the scope was broadened to include wider issues of water management, such as the concerns of recreational groups and tangata whenua (Lomax et al., 2010).

In 2009, after wide public engagement, the Forum released the Canterbury Water Management Strategy (CWMS) which aimed to 'enable present and future generations to gain the greatest social, economic, recreational and cultural benefits from our water resources within an environmentally sustainable framework' (Canterbury Water, 2010, p. 6). Central to the CWMS was a desire to move from effects based, ad hoc water management towards an integrated approach (Lomax et al., 2010). To do this the Strategy suggested new institutional arrangements; the region would be divided into ten catchment based zone committees who were to work within a collaborative framework to develop zone implementation programmes (ZIPs). The ZIPs would address the priorities and principles of the CWMS to provide guidance on water management for the next 30 years and form the basis of statutory plans under the RMA (see Hughey, 2011 for a more detailed explanation of the Zone Committees and ZIPs). A regional committee would deal with issues of particular significance to Canterbury and produce a Regional Implementation Programme (RIP). The exact nature of how ZIPs and RIPs, that were designed in a process external to the RMA, would relate to the RMA planning regime in practice remained unclear (Memon et al., 2012). 
Table 3 Steps leading to the CWMS (adapted from Lomax et al., 2010)

\begin{tabular}{|c|c|c|c|}
\hline Stage & Date & Lead Organisation(s) & Outputs \\
\hline $\begin{array}{l}\text { Canterbury } \\
\text { Strategic Water } \\
\text { Study (Stage 1) }\end{array}$ & $\begin{array}{l}1998- \\
2002\end{array}$ & $\begin{array}{l}\text { Ministry of } \\
\text { Agriculture and } \\
\text { Forestry; Ministry for } \\
\text { the Environment }\end{array}$ & $\begin{array}{l}\text { Evaluation of current and } \\
\text { predicted water supply } \\
\text { and demand }\end{array}$ \\
\hline $\begin{array}{l}\text { Canterbury } \\
\text { Strategic Water } \\
\text { Study (Stage 2) }\end{array}$ & $\begin{array}{l}2004- \\
2008\end{array}$ & $\begin{array}{l}\text { Environment } \\
\text { Canterbury }\end{array}$ & $\begin{array}{l}\text { Identified potential } \\
\text { water storage projects in } \\
\text { Canterbury and their } \\
\text { hydrological feasibility }\end{array}$ \\
\hline $\begin{array}{l}\text { Canterbury } \\
\text { Strategic Water } \\
\text { Study (Stage 3) }\end{array}$ & $\begin{array}{l}2006- \\
2008\end{array}$ & $\begin{array}{l}\text { Canterbury Mayoral } \\
\text { Forum }\end{array}$ & $\begin{array}{l}\text { Evaluation by regional } \\
\text { and local multi- } \\
\text { stakeholder groups of } \\
\text { the environmental, } \\
\text { social, cultural and } \\
\text { economic impacts of the } \\
\text { water storage options } \\
\text { identified in Stage } 2\end{array}$ \\
\hline $\begin{array}{l}\text { Canterbury Water } \\
\text { Management } \\
\text { Strategy (Stage 4) }\end{array}$ & $\begin{array}{l}2008- \\
2009\end{array}$ & Canterbury Water & $\begin{array}{l}\text { Collaborative strategy for } \\
\text { freshwater management } \\
\text { based on measureable } \\
\text { targets }\end{array}$ \\
\hline
\end{tabular}

In late 2009, as the CWMS was released for public consultation, some members of the Mayoral Forum leading the process were lobbying central government to sack ECan councillors and pave a legislative path for the CWMS that was separate to the RMA (Burke, 2013). Central government's involvement in ECan politics was also well-received by some of the ECan councillors that belonged to the rural bloc (Clark, 2010). At this time the Mayoral Forum envisioned that the CWMS would become a statutory tool, and had gone some way to designing a bill they were calling the Canterbury Water Act (Howard 23 
February 2012; Field notes 30 May 2011). However, central government was devising its own, far reaching legislation in the form of the ECan Act, to which the Ministry for Agriculture and Forestry (MAF) was anticipating public opposition. MAF advocated '[s]ome degree of public participation - specifically including the participation of scheme proponents and water users' to increase understanding of the issues at stake and 'go some way towards moderating public opposition' to central government intrusion (Ministry for Agriculture and Forestry, 2009, p. 18). The MAF report therefore recommended that 'government intervene to establish a process - one that can be both rapid and tightly controlled' (Ministry for Agriculture and Forestry, 2009, p. 18, my emphasis). Although the process of rolling out the CWMS had already begun in March 2010, the ECan Act provided an important endorsement of the Strategy, stating that '[i]n considering any proposed regional policy statement or plan, ECan must have particular regard to the vision and principles of the CWMS in addition to the matters relevant under the RMA' (New Zealand Parliament, 2010, p. 28). The newly appointed ECan commissioners also approved the Strategy as the framework under which water management would proceed. Yet the Strategy remained outside RMA planning processes, and therefore didn't have the regulatory status that the CWMS architects had imagined and hoped for. The emphasis on catchment level collaboration and consensus building enabled regional and central governments to stake a claim to democracy (Purcell, 2009), while the CWMS' lack of regulatory standing meant these authorities were also legally able to change or interrupt CWMS processes and maintain their "tight control".

Because of the extremely contentious politics over the Hurunui River (see Chapter 1), the Hurunui Waiau Zone Committee was the first catchment group to be established under the CWMS. The Hurunui Waiau Zone shares its boundaries with the Hurunui District, incorporating the Hurunui, Waiau, Waipara, and Conway Rivers, along with a number of smaller waterways (see Figure 3). As determined by the CWMS, the HWZC consisted of a Hurunui District councillor, one ECan commissioner, two rūnanga members, and seven appointed community members. In order to appoint the community representatives, a panel was assembled that consisted of representatives from ECan, ${ }^{19}$ the District Council, and Ngāi Tahu (Environment Canterbury, 2010). The panel received 30 applications, and

\footnotetext{
${ }^{19}$ Initially two ECan councillors sat on the HWZC appointment panel. After the ECan Act, one of these councillors decided to step down and was replaced by an ECan director (Chris 12 August 2010).
} 
their shortlisting proved controversial. One of the 30 candidates that wasn't initially included on the shortlist was a professor specialising in environmental management. Forest and Bird, a large national environmental NGO, claimed that the lack of environmental expertise on the shortlist indicated the pro-dam development orientation of the Committee, particularly as the chairman of the dam development company was included (Greenhill, 2010b). As a consequence of these claims, the process was delayed as the convenors attempted to assuage the concerns of the NGOs and the public, and maintain claims to being a legitimate democratic body (Dryzek, 2001). The panel ultimately backtracked, and the professor was not only included on the shortlist, but was invited to join the HWZC (Greenhill, 2010b).

Once the Committee members were appointed they were tasked with working in partnership with stakeholders, and 'in a manner that ensures the views of the local community and key stakeholders are reflected in alternatives developed' (Hurunui Waiau Zone Committee, 2010, p. 9). However, while the CWMS refers to "stakeholder representatives" that are appointed to zone committees, from the outset the HWZC members were directed not to act in a representative manner. As part of their collaborative approach, members were told they were:

appointed on the basis of their experience and knowledge and not to represent a particular interest or group. Accordingly members will contribute their knowledge and perspective but not promote the views of positions of any particular interest or stakeholder group (Hurunui Waiau Zone Committee, 2010, p. 10).

Members were also occasionally reminded during Committee meetings that they were not to act in a representative manner (Field notes 18 April 2011). Young (2002) argues that inclusive democracy is based on participation and fair representation; in large polities it is virtually impossible to have everyone engaging in face to face communication, so democracy relies on those who do meet together to act in a representative way. By this Young (2002) means working through processes of authorisation and accountability whereby the representative receives a mandate, and is held responsible for decisions, through wide ranging and engaged public debate. Connections between constituents and representatives are therefore vital to robust democratic processes and outcomes.

Directing members not to be representative, and therefore unauthorised by and unaccountable to constituents, fits poorly with claims that the HWZC and CWMS 
processes would enhance democracy for the public in Canterbury (The Press, 2010). Indeed, the HWZC facilitator, ${ }^{20}$ who had also worked on the development stages of the CWMS, seemed to reject that idea that the HWZC was democratic, instead privileging appointed expertise:

It's not collaborative democracy ... 'cause democracy is about electing people, and the process has been criticised in some public meetings - "why aren't these people being elected?" Fortunately we've had people from [the public and interest groups] in the audience and they've said, "this is about having the right people to do the job". It's not about electing someone who is popular but doesn't actually have the competency, capability, skills and experience to do the job (Chris 12 August 2010).

The instruction to be non-representative was later described by the Committee chair and the Committee facilitator as a requirement to leave 'self-serving views at the door' (Eder \& Whitehouse, 2013). This directive is illustrative of a Habermasian perspective of legitimacy as attained by deliberations that set aside the pluralism of values in the interest of the public good (Mouffe, 2000). However, Young $(1996$, p. 126) warns that when 'participants aim at unity, the appeal to a common good in which they are all supposed to leave behind their particular experience and interests, the perspectives of the privileged are likely to dominate the definition of that common good'. Furthermore, Mouffe (2000, p. 92) cautions against an understanding of politics whereby a 'neutral terrain' can be created in order to reach 'rational' solutions that aren't influenced by the multiplicity of existing values. But from the outset of the HWZC the pluralism of existing ways of valuing and understanding freshwater were expressly constrained.

The CWMS identified a range of principles that must be met. First order priorities are 'environment, customary use, community supplies and stock water' and second order priorities are 'irrigation, renewable electricity generation, recreation and amenity' (Canterbury Water, 2010, p. 9). To meet these principles, zone committees were

\footnotetext{
${ }^{20}$ Each of the ten zone committees was appointed a facilitator who is responsible for facilitating the appointment process, working with the committees to source relevant information, and steering them through relevant rules and regulations to develop a ZIP, and subsequent implementation. The facilitators were employed by Canterbury Water, a directorate of ECan.
} 
instructed to deliver a 'balanced set of quantified outcome targets' (Canterbury Water, 2010 , p. 9). These targets were drinking water, energy security, ecosystem health, water use efficiency, kaitiakitanga, the character of braided rivers, recreational and amenity opportunities, regional and national growth and irrigated land area (Canterbury Water, 2010). While increased irrigation was a second order priority, in a review of the CWMS, Lomax et al. (2010) expressed concern that as the CWMS was developed there was very little critical examination of the goal of greatly increased irrigation in the region. The Strategy therefore consolidated a particular "common sense" within freshwater decision making- that irrigation was necessary, as was economic growth, and the best way to furnish these needs was through water storage. Furthermore, achieving the other CWMS targets was, in practice, seen as at least partly conditional upon economic growth. For instance, one Committee member often stated that the District needed to be 'black to be green', meaning that they had to be financially secure before pursuing environmental targets (Field notes 14 March 2011). This economic model was represented as the only possibility, a move to evacuate dissent and disagreement, and therefore politics, from economics and the environment (Swyngedouw, 2010a). Echoing the CWMS' approach, the HWZC undertook very little interrogation of whether "more water", attained through storing Hurunui River water, and the economic growth that was assumed to follow, was necessary or would even deliver the desired outcomes. For the chairman of the Hurunui Water Project (the company proposing a dam and weir on the Hurunui River, hereafter HWP), large scale water storage was seen as the best way to preserve and enhance his rural community (Hamish 11 August 2010). However, in nearby Culverden the conversions to dairy farms, enabled by an irrigation scheme operating since the 1980s, have resulted in an increasingly casualised labour force. As a result the community has become more transient (Julia 28 November 2011) and anecdotally there is less family ownership of farms (Memon et al., 2012), both characteristics that contrasted with HWP's vision for the towns south of the Hurunui River to be economically and socially vibrant (see Chapter 5).

Radical democrats argue that seeking to resolve conflict through collaboration and consensus building reifies certain rationalities (Mouffe, 2000; Rancière, 2001; Swyngedouw, 2011b), or environmental imaginaries, the place specific 'ways in which a society collectively constructs, interprets and communicates nature' (McGregor, 2004, p. 594). This reification is to the exclusion of those who do not begin from a shared understanding of the situation (Swyngedouw, 2007). Because the CWMS had already 
established the outcome targets, people that applied to the Committee had to be able to understand and articulate what the problem was in a way that was intelligible within a CWMS rationality that sought "more water" (Rancière, 2001). From the outset then the CWMS shaped the 'social acceptability and social influence of different environmental discourses' on the HWZC (McGregor, 2004, p. 594, emphasis in original). Four months after the first public meeting of the Committee, one member set out his concerns about how the "more water" environmental imaginary structured what was legitimate on the HWZC (Swyngedouw, 2007) and how the boundaries of acceptability channelled the Zone Committee towards certain outcomes:

What I see at the moment is there seems to be a focus on damming the Hurunui and the amount of information on alternatives is limited. I do wonder whether we're getting channelled into coming out with a recommendation that says "yes it looks like the dam on the Hurunui is the best alternative, the best option and we'll recommend that". And I'm thinking to myself, well what do you need us for? ... [O]ther people could say that yes the dam on the Hurunui could go ahead, but that would go through the Resource Management process. Then the kayakers and the Fish and Game ${ }^{21}$... they would all jump up and down and say "no that's not going to happen". But you put us all into a committee, and a committee is a consensus of opinion, you stack the Committee with potentially pro Hurunui dammers, then to get [consensus] is not a hard option (Brad 5 November 2010).

Here the participant expresses concerns about the limited information being presented to the HWZC by ECan and those seeking to develop water storage about possible options for alternatives to damming the mainstem of the Hurunui. He also suggests that the HWZC's purpose is to provide democratic legitimacy to a process, and an outcome, that is outside the current planning paradigm.

The way that the "more water" rationality was reified by the Committee in practice was perhaps best illustrated during a meeting early in the process. On 18 October 2010 in Waipara two representatives of the Canterbury based Whitewater Canoe Club (one also representing Whitewater NZ, a national group for kayakers and canoeists) delivered a

\footnotetext{
${ }^{21}$ Fish and Game is an NGO that simultaneously advocates for hunters and anglers, and conservation issues, using the licensing fees of the former to partly finance the latter.
} 
presentation to the Committee about kayaking in the Hurunui Waiau Zone and why the rivers were important to them. These values were largely non-economic, based instead on intrinsic value and the affective nature of the rivers. One of the presenters felt he was 'heckled' throughout (Henry 1 November 2011; also Brad 5 November 2010), and at the conclusion of the presentation they were told that if they disagreed with the proposed dams, the kayakers should come up with their own storage proposal (Henry 1 November 2011). The kayakers and others did subsequently mobilise to develop another storage option, a dam in the Waitohi Valley to which extracted Hurunui water would be pumped. Storage in the Waitohi Valley subsequently became the preferred option by the HWZC. In response, HWP developed its own plans for storage on the Waitohi. This new scheme would see the staged development of four dams covering an eight kilometre stretch of the Waitohi River, into which Hurunui water will be pumped (see Figure 4). These dams would generate some power, and eventually irrigate over 58,000 ha of land via a series of canals, 16,000ha more than HWP's original South Branch dam and Lake Sumner weir proposals.

The Waitohi option was viewed as more amenable to a number of people and groups than a dam on the Hurunui mainstem, particularly to those concerned with environmental and cultural issues. It is, however, significantly more expensive that HWP's original South Branch and Lake Sumner storage schemes. According to the project manager for HWP, reaching a storage outcome that was more acceptable to activists and environmental groups was the result of 'stepping back from the courts' and working through the CWMS and HWZC process (Loeffen, 2012).

Despite reaching a more satisfactory "more water" option, according to Ghose (2005) and Kapoor (2005) setting specific outcomes for collaborative processes risks narrowing possibilities and distorting participation, which was clearly the case in this process. The prescribed outcomes, in this instance, considerably constrained the range of environmental imaginaries that could be legitimately articulated and heard on the Zone Committee as the kayakers were heckled and forced to come up with an alternative "more water" option that mitigated some of their concerns. Specifically addressing the HWZC, Memon et al. (2012, p. 22) warned that the targets assigned to the Zone Committee acted to 'close off discussion of some potential paths of inquiry and imposes artificial and 


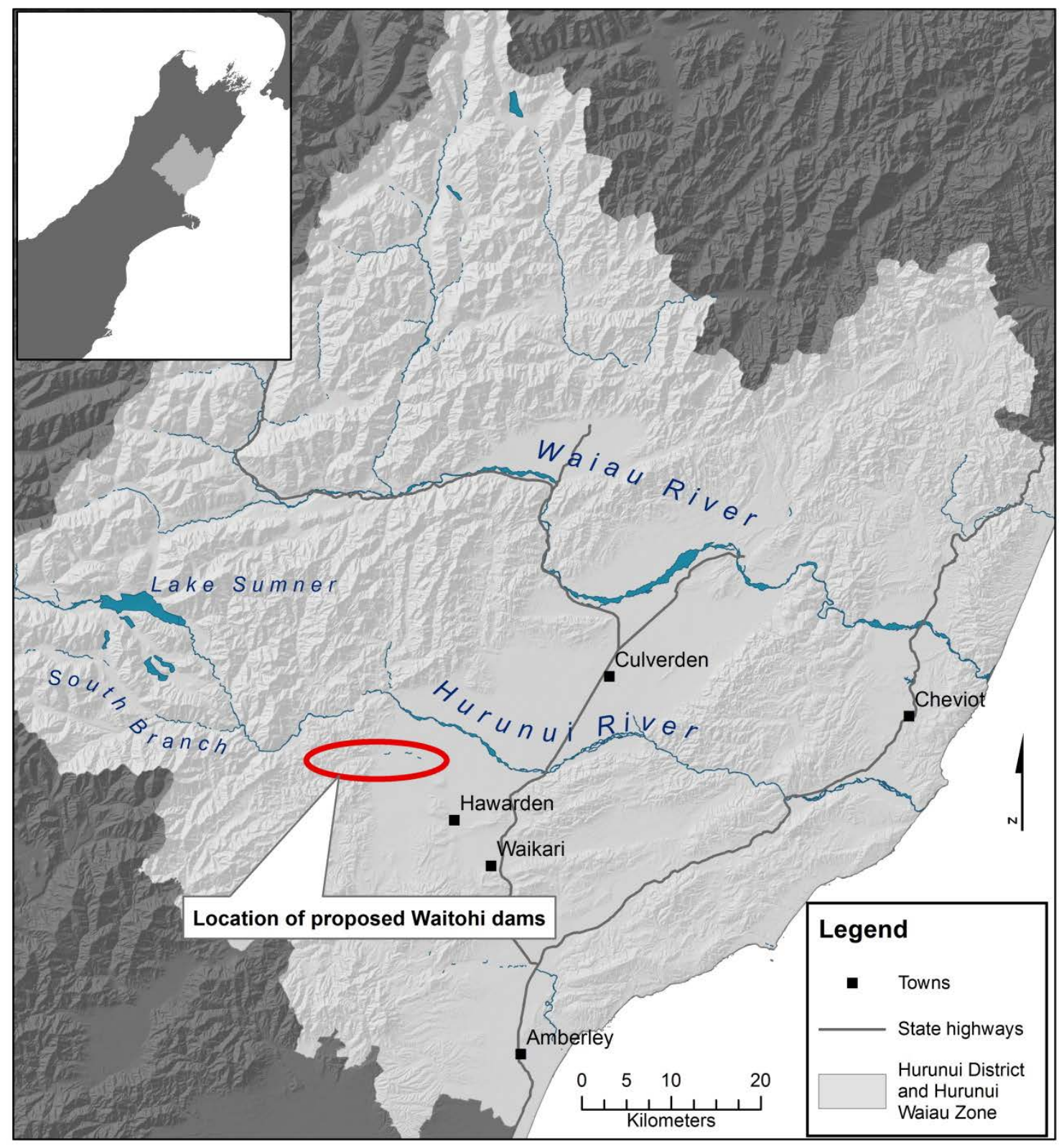

Figure 4 The Hurunui District with the Waitohi storage scheme highlighted

possibly counter-productive boundaries around issues that cannot and should not be bounded, at least initially, in a collaborative and deliberative process'. The fixed goal of the HWZC (increased water storage) meant the Committee was constrained in its ability to explore the plurality of ways of valuing the river and alternatives beyond an instrumentalist "more water" rationality (Gibson-Graham, 2006). For at least one member of the public, these limitations affected the potential of the HWZC:

If you try to put a boundary around an argument I'm always going to break it, because ... whenever there's constraints, well, ideas can't grow, so you've got to 
break down all of the constraints and say "this idea must go wherever it can". And that way you make change, we develop (Ben 14 November 2011).

In establishing that the Zone Committee was to operate within a terrain that set aside the plurality of values, and privileged a particular environmental imaginary as the touchstone of intelligibility, a constrained political space was established that protected neoliberal values of economic growth through the enclosure of nature.

\subsection{Creating responsibility within a "more water" paradigm, and circumventing collaboration}

In spite of the "more water" paradigm, and the way this affected the Committee process, the Zone Committee did recommend some innovative measures in its Zone Implementation Programme that addressed some of the impacts of increased water storage and irrigation. Released in July 2011, just a year after the first public meeting of the HWZC, the ZIP was designed to form the basis of a Hurunui Waiau River Regional Plan (HWRRP), a statutory plan under the RMA (see Figure 5). ${ }^{22}$

Intended to secure the prosperity of the District through the 'utilization of its water resources, for agricultural and horticultural development through the expansion of irrigation, and tourism activities' (Hurunui Waiau Zone Committee, 2011b, p. 2), the recommendations in the ZIP did not contest directives to secure more water. However,

\footnotetext{
${ }^{22}$ According to Schedule 1 of the RMA, regional plans guide all rules and policies of the territorial authorities within that region.
} 


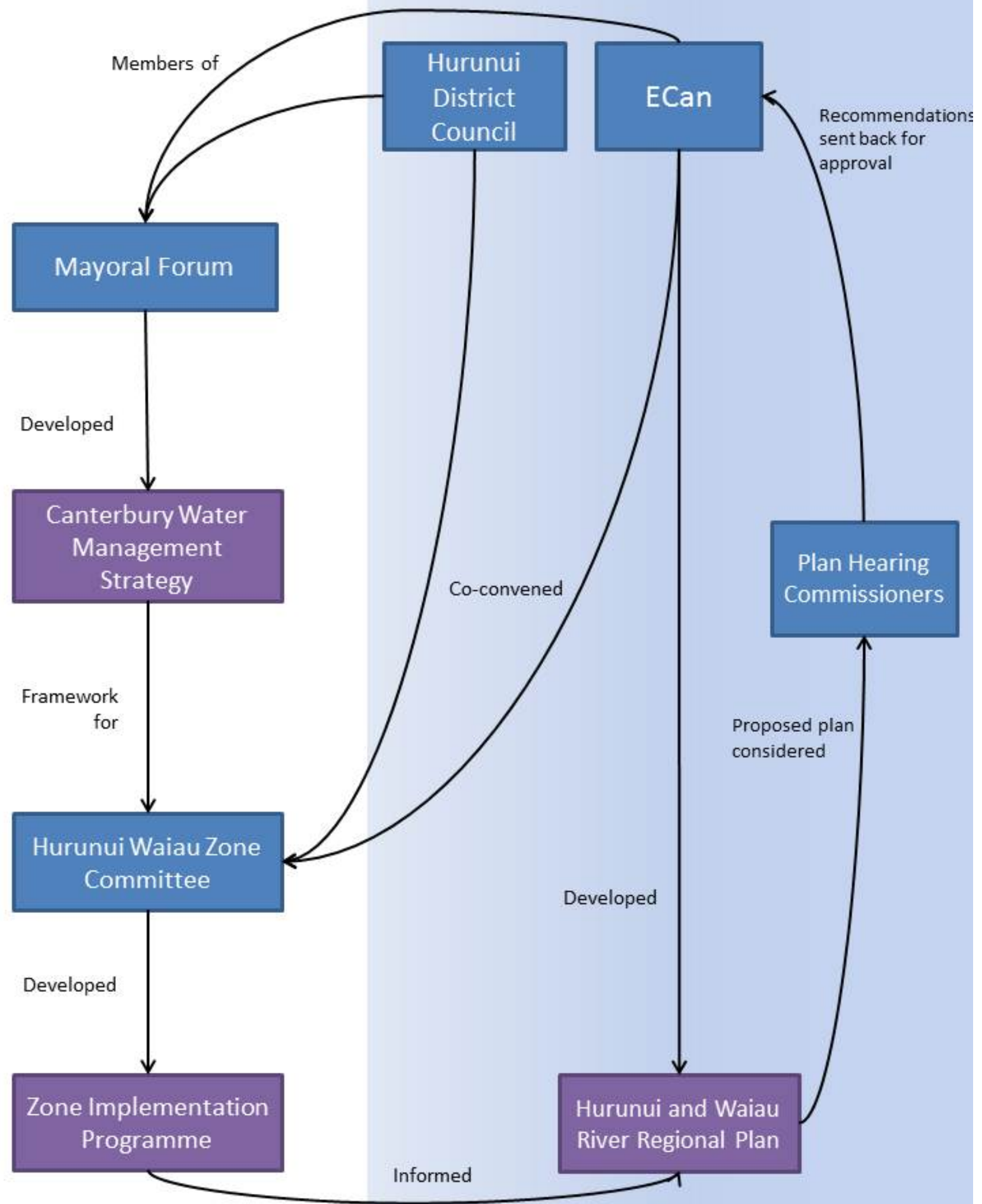

Figure 5 The process of developing water regulation in the Hurunui District. 
achieving prosperity, the document acknowledged, would depend on maintaining 'environmental outcomes' through increased monitoring of river water quality, flow and allocation regimes, and biodiversity improvement schemes. In addition to these commonly used tools, the HWZC proposed a new set of responsibilities for water use in order to address nutrient loading in the Zone's rivers. The Committee determined that the quality of the two main rivers should not get any worse. In order to achieve this goal, the ZIP stated that nutrients, particularly phosphorous and nitrate, would need to decrease to a point where new irrigation could be developed without 'compromising water quality outcomes' (Hurunui Waiau Zone Committee, 2011b, p. 35). This goal required the Committee to address existing land use practices. They therefore determined that for land use to remain a permitted activity (an activity that does not require a resource consent), property owners needed to be part of a catchment or industry management plan before 2017 and have implemented audited self-management programmes that would monitor nutrient loss from the land to the rivers. Land use conversion would be dependent on the catchment remaining within the established nutrient loading limits. Should the catchment exceed limits, a resource consent would be required, and the application for the consent would need to give regard to other land users in the catchment and their nutrient use and loss (Environment Canterbury, 2011). Through these measures the HWZC established that no new irrigation could be developed until existing land users created head room in the nutrient loading of the river. The agreed matrix was projected to mean the Hurunui and Waiau Rivers would be within the algae growth limits (specifically periphyton, often an indicator of high concentrations of nutrients), set out in the regional Natural Resources Regional Plan, four years out of five (Hughey, 2011). These measures presented a complication to the dominant discourse of linear economic growth in the District that was inconsistent with central government's 'short-term macro economic objectives' (Lomax et al., 2010). Namely, they troubled an economic growth strategy that rested on the privileged place of unfettered private property rights (Wilson \& Memon, 2005, see below). In light of this complication, the mayor of the Hurunui District Council (who also sat on the HWZC) and a representative of Ngāi Tahu Property voiced concerns that the ZIP's nutrient limit recommendations would preclude economic development in the area (Field notes 19 September 2011; letter from Peter Skelton, ECan commissioner, to Anderson Lloyd lawyers 30 September 2011). In the month following the public release of the ZIP, the ECan commissioners met to discuss these concerns, which they shared, and how these 
barriers to economic growth affected the development of the Hurunui and Waiau River Regional Plan, for which the ZIP formed the basis (Hurunui Waiau Zone Committee, 2011a; see Figure 5). Later, one of the commissioners justified ECan's concern on the basis that the Zone Committee hadn't properly reached consensus on the issue of nutrient loading (Caygill, 2011), something with which at least one HWZC member strongly disagrees (Hughey, 2011) and the ZIP itself seems to refute. Nevertheless, in the dying minutes of the HWZC's August meeting ECan planners recommended a different approach that would allow increased nutrient loading. The HWZC members were suddenly confronted with the fact that the collaborative process, through which the ZIP had been developed, had been circumvented; ECan had largely reverted to the RMA planning process in which regional authorities design, develop, and consult on plans, trumping the HWZC, which was not recognised under the RMA, and thereby maintaining their "tight control".

The full implications of the situation were not realised until after the meeting as ECan planners proposed various options for increasing the load limit, and it was another month before the effects of ECan's position on the ZIP could be debated in person by the HWZC at their September meeting. In 2010, the government had imposed moratoria over the Hurunui and Waiau Rivers, suspending consent applications and providing time for the development of a regional resources plan to guide future consenting decisions. The moratoria were due to expire on 1 October 2011, enabling the resource consent process to resume. ECan was, therefore, eager to have a plan notified in order to inform any consent applications. ${ }^{23}$ In the face of this pressure, the proposed Hurunui and Waiau River Regional Plan, authored by ECan, was publicly notified on 1 October, and public submissions invited. The proposed plan acknowledged the position adopted by the HWZC, but stated that the constraints on nutrient loading contradicted other elements of the plan, namely economic development (Environment Canterbury, 2011, see p. 9). As a result they proposed allowing a 20\% increase above 2005-2010 nitrogen limits on the Hurunui River prior to the 2017 measures coming into force, in order to enable new irrigation during this time (Environment Canterbury, 2011).

\footnotetext{
${ }^{23}$ Proposed plans have statutory weight but must pass through processes established under RMA Schedule 1 consultation and hearing processes, and be approved by the local authority in order to become fully operative plans.
} 
After more than a year of dedicating time well beyond the initial role description, many of the Committee members were extremely upset by the actions of ECan. They understood that they were a joint committee of the Hurunui District Council and ECan, and were aware that their recommendations lacked statutory weight until passed through a planning process (Field notes 19 September 2011; Duncan 4 November 2010). Further, the Zone Committee's code of conduct clearly stated that they could not commit either of the territorial authorities to any course of action. However, the Zone Committee's operating philosophy stated that there would be a "no surprises" relationship with both the District Council and ECan (Hurunui Waiau Zone Committee, 2010), and at a meeting three months prior to ECan's interference, the commissioner to the HWZC had told the Committee that there was every indication ECan would approve the ZIP (Field notes 30 May 2011). There was a very clear understanding that the HWZC's engagement with the community, and the consensus they reached, would form the basis of the plan (Field notes 19 September 2011). Had this not been the case, the meaning of the HWZC's work would have been rather opaque. Early in the Committee's work, while acknowledging the uncertain regulatory terrain for water management, the HWZC facilitator (employed by ECan) commented wryly that it would 'be a very heroic or courageous' council that rejected the recommendations of the Zone Committee (Chris 12 August 2010). The Committee had been delegated responsibility to undertake a particular process and there was no indication that ECan would so fundamentally circumvent the Zone Committee's work at any time.

In the face of the ensuing public fall-out from the intervention that largely played out in the regional newspaper The Press, the ECan commissioners retreated somewhat. They asked the Zone Committee to reach a new consensus agreement on nutrient limits that the commissioners could then use as the basis for their submission to the independent panel charged with hearing submissions on the Hurunui and Waiau River Regional Plan (Hughey, 2011). Many of the HWZC members believe that the limits subsequently proposed by the Zone Committee, based on nutrient concentration rather than total amount, were an improvement on both the Zone Committee and ECan's proposals (Shona 18 March 2012; Brian 16 February 2012; Brad 21 February 2012). However, at the September 2011 meeting of the HWZC, the effect on Committee members' feelings of trust and agency were apparent. One Committee member stated that he was 'incredibly upset by the process [undertaken by ECan]... I have no idea what the justification for this is 
... I feel that I've been shot in the back about this' (Field notes 19 September 2011).

Another Committee member questioned who ECan was acting for, particularly given the influence DairyNZ, a dairy industry organisation, was reported to have exerted. Their scientist presented at the August meeting in favour of changing the nutrient loading provisions. The Committee member stated that it 'just made me furious ... who are ECan representing - the dairy sector or the community?' (Field notes 19 September 2011; also Brad 21 February 2012). In a later interview with the same participant, Max, it was clear that far from just damaging the trust formed within the Committee, ECan's interference almost precipitated the collapse of the whole process. Fish and Game, a vocal NGO who the participant worked for, were very close to withdrawing their support for the HWZC and the CWMS. In December 2010 they, along with Whitewater NZ, had withdrawn their application for a Hurunui Water Conservation Order, stating that the protection tool had been significantly undermined down by the ECan Act and that they wanted to work within the collaborative CWMS approach (see Whitewater NZ, 2010). When asked how badly the circumvention threatened existing Committee membership, Max stated:

Very badly, more than they actually know. Fish and Game had all sorts of emergency national meetings where we flew people in to talk about our action. We were thinking of lodging a Water Conservation Order within two days to deal with water quality issues and trumping the ECan planning process ... I think it's just added to the general mistrust that people have about commissioners running ECan as well. So I think it's had a huge effect. If ECan hadn't resolved it, come back and put in a submission [to the hearing panel] on our behalf, I think it would have split the Zone Committee apart (Max 22 February 2012).

Furthermore, the HWZC facilitator felt that the interference by ECan had jeopardised the entire CWMS (Chris 23 February 2012). In contrast, an ECan commissioner thought that the issue was 'a storm in a teacup' and that threats to leave the process were hollow (Howard 23 February 2012). He stated, 'I don't think they would have walked away from it, actually. In fact I'm pretty confident that they wouldn't ... I was never very worried about the [CWMS] process coming to a grinding halt over the Hurunui thing' (Howard 23 February 2012). The commissioner believed that if any Committee members had resigned they would have simply been replaced and the HWZC carried on as per normal (Field notes 16 November 2011). One Committee member, who had contemplated leaving the HWZC, 
strongly disagreed, arguing that '[i]t would have lost all credibility in the eyes of the larger community' (Tim 14 February 2012).

Indeed, the incident had already resulted in the public questioning how collaboration was being enacted. By August 2011, environmental NGOs, individuals and government agencies had spent years developing the CWMS, investing time, resources and their own reputation to collaborate widely. Many of these groups were initially optimistic about the CWMS and Zone Committee's progress. However, just as MAF had recommended in 2009, the Zone Committee process was one that could be controlled by regional government in a way that previous court-based processes could not, and be circumvented where necessary to achieve economic development. Here, collaboration functioned as a means to enrol and diffuse resistance as citizens' resources were captured by the CWMS framework (Ghose, 2005). One member of the public described how she had initially been extremely hopeful about the HWZC and had participated in meetings, but ECan's actions had left her deflated:

Julia: It just seemed inevitable that this fantastic idealism of compromise, when it actually came to the crunch, just disappeared, just caved in. And you were back to the vested interest, getting a result that they were always confident they would get anyway: if you can't get it through the normal channels you get it anyhow you can by just going straight to ECan. And actually since then I've rather lost heart in it. I haven't been to any Zone meetings since then. I've only just been following it through the way it's been reported in the paper.

Amanda: So do you feel that [the actions of] ECan undermined the principle of collaboration?

Julia: Completely. It just made a total mockery of the whole thing. The whole thing was extraordinary, you know, it was marvellous, it was wonderful, it was terrifically idealistic. But this just made it a joke. You just felt what was the point of going through the whole exercise? (Julia 28 November 2011).

Some members of the public who were initially sceptical of the process had felt encouraged by the gains they saw the Zone Committee making, and were disillusioned by the way it was disregarded: 
From having signed off on the ZIP people changed their tune, so we did achieve something for a while where they were taking responsibility seriously. I'm not quite sure about now though. I find the whole process extremely painful now (Louis 31 October 2011).

In the following year and half, the proposed plan was considered by an independent panel of hearing commissioners acting under the RMA (see Figure 5). At the time, the HWZC facilitator stated that the 'challenge ongoing through the statutory planning process is how to ensure that the hearing panel delivers on all the ten CWMS targets because at one level, their RMA responsibilities are a lot narrower than the ten targets' (Chris 23 February 2012). In releasing their recommendations in early April 2013, the hearing commissioners recognised the expectation that the ZIP would form the basis of the plan, but were also influenced by public and industry submissions (162 in total) made to the hearing commissioners (Environment Canterbury, 2013b). The panel thought the evidence of the water scientist for Fonterra and Dairy NZ about nitrogen loading was particularly convincing, stating that her evidence was key in determining an appropriate increase (Environment Canterbury, 2013b). The panel subsequently approved a $25 \%$ increase in nitrogen levels in the Hurunui River, as per ECan's original desire in August 2011, stating that doing so would balance the risks to river health while 'enabling social and economic wellbeing through increased irrigation and associated conversion of drystock farming to dairying or other intensive land uses' (Environment Canterbury, 2013b, p. 46). However, the panel also drew on the findings of the special tribunal that had investigated the application for a Water Conservation Order between 2008 and 2009. As discussed in Chapter 3, the threat of a Hurunui Water Conservation Order to irrigation development was a significant factor in extending the scope of the ECan Act to deal specifically with the Hurunui River. Ultimately the 2013 hearing panel decided to go beyond the ZIP and the recommendations of the WCO special tribunal in protecting the Hurunui mainstem, and rezoned the entire mainstem of the river to preclude on-river storage through dams or weirs.

Somewhat perversely, section 66 of the ECan Act explicitly rules out recourse to the Environment Court on any aspects of the plan's content. Applications for judicial review (rather than appeals based on the content of the decision itself) can still be made to the High Court, and at the time of writing three appeals against the plan had been lodged. 
Despite the CWMS' intentions to reduce costly litigation, Fish and Game, Amuri Irrigation Company (which provides irrigation water for the Amuri Basin around Culverden) and the Hurunui Water Project have lodged arguments that the Council erred in its lack of regard for national guidelines about water quality (Fish and Game), failed to give regard to the CWMS by not placing importance on existing irrigation activities and infrastructure (Amuri Irrigation Company), was not within its jurisdiction to restrict nutrient load limits, and did not adequately assess the costs of prohibiting dams on the Hurunui mainstem (HWP). Should HWP's appeal against the rezoning fail, and the Waitohi Valley storage option prove too expensive for farmers, on-river storage on the Hurunui will need a plan change to proceed. Changing a plan requires councils to have the political will to investigate doing so, or a private entity can request a plan change under section 65 of the RMA (which in practice is extremely costly), and then public submissions must be invited and heard. This zoning of the Hurunui River, therefore, sets a very high bar for on-river development. The panel's decisions that contrasted with the ZIP, and the appeals to the High Court, raise interesting questions about the continued meaning of the CWMS within a planning framework that is still based on the RMA and gives primary control for planning development to regional councils, questions that have been hinted at throughout the CWMS roll out (Lomax et al., 2010).

The following section will return to a focus on the Zone Committee process itself. Below I explore how the particular political paradigm in Canterbury left those members of the public who were disillusioned with the collaborative and consensus based process suspended in a state of exception. Further, I examine the post-politicising processes enabled by the state of exception regulatory paradigm.

\subsection{Collaboration in the state of exception as a post-political process}

The circumvention of the Zone Committee, and its work more broadly, cannot be separated from central government's reshaping of regional environmental governance in an effort to secure more water quickly. As detailed in the previous chapter, the ECan Act constrained voting rights and access to justice in an overt display of the state of exception. Within this re-regulated landscape MAF had recognised the potential for opposition and the need for a degree of public participation. Yet participatory processes were mediated through a chain of appointed representatives - the central government appointed 
commissioners (one of whom sat on all nine zone committee appointment panels after the HWZC), and a panel appointed the Zone Committee. Neither the Zone Committee members nor ECan commissioners were subject to democratic elections that would normally force a degree of responsiveness to the wider public. When asked who he considered himself responsible to, an ECan commissioner acknowledged a 'duty' to the public, but was clear that above all he was beholden to central government, stating 'I am appointed by the government so I am responsible to the government' (Howard 23 February 2012).

The state of exception created a political paradigm of instability for citizens, where laws can be, and are, changed with little or no public engagement or opportunity for legal review. For at least one person, the instability of the state of exception undermined the potential for a collaborative ethic on the HWZC, emphatically stating, 'collaboration's a word, it's not collaboration. It's not collaboration. It can't be collaboration as long as you know laws can be changed any moment' (Ben 14 November 2011). More specifically another research participant saw government's willingness to intervene as limiting the possibilities for the Zone Committee to engage with a range of environmental imaginaries:

I mean imagine a situation where a zone committee came up and said, "you know what, we can't meet these other targets, we can't meet the drinking water target, we can't meet the braided rivers target so therefore we're not going to do infrastructure." I mean that's absolutely unimaginable in my mind that this Zone Committee would ever come to that decision. And if they [did], I think under the current central government they would go "no, no, no you can't reach that decision" (Anna 24 November 2011).

The state of exception has provided an effective means to actively police debates about freshwater. Policing is carried out through the rendering of decision making about water as an administrative function in which dissensus and contestation are inappropriate (Swyngedouw, 2010a). This is evidenced by central governments' willingness to pass laws under parliamentary urgency with virtually no public engagement (Joseph, 2010) and an ECan commissioner's directive to the HWZC to reach consensus in order to limit the amount of public debate when the ZIP was released (Field notes 16 August 2010). These processes are de-politicising because they close spaces where questions about the 
'content and direction of socio-ecological life' can be asked and discussed (Swyngedouw, 2010a, p. 225).

The position of the Zone Committee in relation to regional and central government illustrates the vulnerability of participatory approaches to a situation 'whereby the state retains discursive and policy control over rhetorically independent voluntary organizations as a means of managing and subverting any potential for political opposition and thus ensuring its own political agenda' (Brownlow, 2011, p. 1270). The manner in which collaborative approaches can be operationalised to quash dissent lends itself to (neoliberal) hegemonies, reinforcing neoliberal myths of inevitability (Leach et al., 2007; Purcell, 2009). The CWMS within the central government's state of exception can be viewed as a tool for cultivating post-politics in the sense that it does not create space to contest neoliberal assumptions, and is able to be shaped and redirected through (real and possible future) interruptions of zone committees and reordering around a new consensus should they complicate ambitions for more water.

On the HWZC, limitations on members' ability to express dissensus were at times keenly felt. At a 2011 meeting one member voiced his disagreement with criteria informing a biodiversity fund the HWZC was in charge of allocating. However, he stated that he wouldn't pursue these objections because he didn't want to obstruct consensus (Field notes 19 September 2011). Another Committee member felt that the pressure to reach consensus led to a consolidation around neoliberal goals because the consensus position is always going to compromise one side of that argument, which is inevitably that environmental side' (Max 22 February 2012). This is one of the dangers of consensus building - in reaching consensus there is always an "outside" created 'since decisions require some form of sorting values which prefers some values to the relative repression and/or exclusion of others' (Hillier, 2003, p. 42; Kapoor, 2005). It's not possible for decisions to meet the needs of all values and as a result '[c]onsensus in a liberaldemocratic society is - and will always be - the expression of a hegemony and the crystallization of power relations' (Mouffe, 2000, p. 49). Despite most deliberative democrats rejecting the value and possibility of consensus (Dryzek, 2001), it was an ideal adopted by CWMS' architects. The result was that the goal of consensus policed the boundaries of debate on the HWZC, as disagreement was viewed as obstructive to their work. Therefore discussion often crystalized around neoliberal understandings of nature; 
directives to reach consensus within the already established goal of "more water", at times, acted as a constraint to 'the articulation of divergent, conflicting, and alternative trajectories of the future environmental possibilities and assemblages' on the HWZC (Swyngedouw, 2013b, p. 5). Limitations on the articulation of different environmental imaginaries shaped the outcomes of the process, leading some Committee members to the understanding that through the "more water" paradigm, nature had been sacrificed through increased water abstraction and impacts on habitat health (Tim 14 February 2012; Max 22 February 2012).

Members of the public who attempted to question the dominant rationality were rendered as illegitimate within that space (Mouffe, 2005). One interviewee in particular viewed the Zone Committee's work within Canterbury's unstable political paradigm as foreclosing genuine debate and disagreement:

[l]t's as if the goal posts are becoming narrower and narrower to the point where the ball won't even pass between the posts anymore. At that point you shouldn't be involved, they shouldn't be. I've said to these guys, "come on, let's just disengage. Disengage, meet somewhere, have a news conference and say, ah there's a huge rort ${ }^{24}$ going on"... as long as they've got us looking like we go through a collaborative process they can carry on doing the dirty work. So we've got to pull out of it, let them do the dirty work and be obvious about it (Ben 14 November 2011).

Further, on a website he created as an art-activism project, the participant stated that undermining claims to environmental democracy in the region requires people 'to occupy the unoccupied space and then be appalling'. For him this involved a suite of actions - coorganising a public protest in the main square in Christchurch, a public sculpture incorporating a poem about water, and an interactive website - that questioned assumptions about economic growth through freshwater enclosure, and invited public engagement and debate. The participant sought a more genuinely democratic space in the sense that 'the unnamed, the uncounted, and, consequently, unsymbolized become named and counted' and become visible within freshwater politics (Swyngedouw, 2007, p.

\footnotetext{
${ }^{24}$ Rort is a term used in Aotearoa New Zealand and Australia to describe a scam, or a situation in which someone is being taken advantage of.
} 
34, drawing on Rancière). The unnamed in this instance are people that resist the predetermined goal of large scale water storage and contest post-politicising environmental imaginaries (the process of othering and excluding these people will be explored in Chapter 5). For both Žižek and Rancière, authentic politics requires that the people who are excluded and uncounted contest the existing order (Swyngedouw, 2007). Žižek (1999b, p. 199, emphasis in original) claims that the truly political, 'authentic politics', is 'not simply something that works well within the framework of existing relations but something that changes the very framework that determines how things work'. It is 'the art of the impossible' in the sense that it remakes the entirety of social space (Žižek, 1999b, p. 199). Accordingly then, truly political moments are rare. Swyngedouw (2013b, p. 6) argues that remaking environmental possibilities requires 'exploding the infernal process of de-politicization'.

However, just as neoliberalisms have been reified as monolithic, and therefore beyond contestation (see Chapter 3), radical democrats' characterisation of authentic politics render post-politics as unitary, stable and to a degree inevitable. Consequently the criteria for authentic politics have been subject to growing critique that contends that postpoliticising processes are unstable, and there are multiple ways in which they are resisted (Featherstone, 2013; McCarthy, 2013). The following section will explore three brief examples of how post-politicising processes in the Hurunui Waiau Zone were contested, and argues for a more nuanced framework that creates room to acknowledge the potential of resistance that falls short of "exploding" post-politics.

\subsubsection{Troubling post-politics - social learning, challenging rationalities, and destabilising legitimacy}

The work of the Zone Committee troubled post-politicising processes in three ways. The first complication of post-politicisation was through transformative social learning. The HWZC held numerous meetings in the District, rotating around the small rural towns, as well as in Christchurch, and held sessions where industry and NGO representatives presented on their perspectives of Hurunui River management. There was general agreement that the Zone Committee had worked incredibly hard to engage with a broad spectrum of views. In a review of all zone committees Bestwick $(2012$, p. 25$)$ found that the aspects of committee work that members found most valuable were 'exposure to 
different perspectives' and 'information sharing and education'. The type of learning that took place on the HWZC included an increased understanding of the complexity and uncertainties of water science, planning processes, and the range of existing values, which generated feelings of trust (irrespective of how the values were treated within a "more water" paradigm) (Brad 21 February 2012; Shona 18 March 2012; Hamish 16 February 2012; Field notes 30 May 2011). The engagement with different perspectives by Committee members reflects Habermas' belief that the space created for dialogue within deliberative processes can generate intersubjective understanding (Habermas, 1996; see also Innes \& Booher, 2004).

Significantly, through the collaborative process HWZC members were engaged with transformative social learning about Ngāi Tahu understandings of the environment (see Chapter 6 for a more in depth discussion of Ngāi Tahu worldviews and the learning that took place). Bond and Thompson-Fawcett (2007, p. 467) state that 'transformative learning' enhances 'tolerance, empowerment and social capital'. Young (1996) argues, communicative planning can lead to beneficial learning when participants come to understand the partial and situated nature of one's own knowledge and experiences. This understanding develops empathy for the ways other people and things are affected by decisions. Increased tolerance and understanding was particularly important to a District that had very recently seen contestation over Māori involvement in environmental decision making, contestation that had descended into racism (see Chapter 6; Hamish 16 February 2012; Joyce 14 February 2012). One participant, who had not been to a marae (meeting house and the complex around it) before the Zone Committee held a meeting at Takahanga Marae in Kaikōura, stated that the visit to the marae was a 'real highlight' of his work on the Committee (Hamish 16 February 2012). Over time he has come to accept that the rūnanga occupy a place as tangata whenua 'that's different to other people' (Hamish 16 February 2012). Another participant stated that the rūnanga representatives 'certainly let us know what the values are for them and in that respect, there's things that I would never have thought of if they hadn't been there' (Shona 18 March 2012). However, despite the Committee's exhaustive schedule of meetings in different towns throughout the Zone, members generally agreed that little of the understanding they developed within the HWZC membership was shared with the broader community (Hamish 16 February 2012; Duncan 20 February 2012; George 14 February 2012). This is likely the outcome of the directives at the outset of their work that Committee members 
do not act as representatives of their publics (see above). Members were not, therefore, responsible and accountable to communities for sharing and communicating the transformative moments they experienced on the $\mathrm{HWZC}$ - they were there to share their 'experience and knowledge' (Hurunui Waiau Zone Committee, 2010). To a degree, this meant that aspects of the HWZC process were inward looking, and the extension of shared understanding outwards to the public was limited (Young, 1996, 2002).

Yet importantly, the values that rūnanga representatives particularly emphasised, and that were influential, related to a more responsible relationship with rivers in the Zone, which troubled neoliberal rationalities:

[W]hen we [Pākehā HWZC members] got to understand what kaitiakitanga actually meant, the concept of sort of stewardship and obligations and rights, those are concepts that most people can actually buy into, the idea that if you use the river, you've got some obligation to look after it as well (George 14 February 2012).

Although the Zone Committee space worked to consolidate the "more water" rationality in other ways, and some members were unhappy with the sacrifices the environment was forced to make, rūnanga complicated the dominant understandings of nature.

Principles of responsibility advocated by rūnanga also contributed to the outcomes of the Committee's work, and the second dimension of the HWZC process that troubled accounts of relatively linear post-democratisation processes. Although ECan rejected the ZIP's recommendations for nutrient loading in the major rivers, other aspects of the ZIP that were incorporated into the Proposed Hurunui and Waiau River Regional Plan affected consent statuses for land use, as detailed above. The proposed plan established that by 2017 landowners or occupiers had to belong to a catchment agreement, industry certification structure, or an irrigation scheme management plan in order for land use to remain a permitted activity from 2017 (Environment Canterbury, 2011). These collectives have to prepare farm environment plans to encourage alignment with best practice. Furthermore, according to the plan any land use change that results in river nutrient loading limits being exceeded is deemed a non-complying activity that requires a resource consent. These tools were approved by the hearing commissioners in April 2013 (Environment Canterbury, 2013a). 
Land use in Aotearoa New Zealand does not require a resource consent unless it breaches a national standard, or regional or district plan rule, and there is currently a limited range of activities that require land use consent in Canterbury. There is also a normalised culture of conventional farming practice that involves high inputs (of fertilisers and chemicals) that promote production, and these inputs are largely unregulated, as are nonpoint source (or diffuse) pollution such as animal excrement. Other local authorities have recently looked to introduce rules that change land use consent status in order to improve freshwater quality. Yet these efforts have proven to be extremely contentious (see Horsley \& Galloway, 2012) because private property rights, unfettered by regulation, have been 'one of the key principles' shaping public policy in Aotearoa New Zealand since colonisation (Wilson \& Memon, 2005, p. 1503). Indeed the freedoms of private property rights were a key drawcard for European settlers, who subsequently went about "improving" the land for farming through dramatic clearance of native bush and draining wetlands to create pasture. The proposed constraints on land use in the Hurunui Waiau Zone complicate, to an extent, dominant private property rationalities that are closely linked to neoliberalisms (Wilson \& Memon, 2005). These changes hint at more responsible ways of living with more than humans. In creating these constraints the principal ECan planner stated that he hoped it would lead to proactive behaviour by land users - the design of the measures meant that they acted as a backstop whereby ECan could use the 'plan not to actually make rules for people but to make rules for the people who don't do what we're asking them to do' (Luke 29 November 2011). The crafting of this rule meant that ECan could, to a degree, avoid accusations of over-regulation. The ECan commissioner on the Zone Committee stated:

We wanted to leave the responsibility with the individual farmers and the communities they were part of ... At the end of the day if they achieve what they have to do, there won't be any more regulation because they'll have the nutrient levels that they need to have and there won't be any need for anybody to make an application for consent to change their farming practice. So the idea of having a consent to farm is there but we've tried to say [that] whether that has to happen [or not] is very much about how the community reacts to the reality of a world that says rivers have to be cleaner than they used to be and we have to manage them, we have to be seen to be managing them effectively (George 14 February 2012). 
The fact that these measures were not contested by ECan commissioners in the same way that the measures around water quality were, reflects that there was some acknowledgement that greater responsibility needed to be taken for water pollution, and is perhaps also due to the public backlash against their interference with the HWZC.

Thirdly, although the circumvention of HWZC by ECan was damaging to Committee trust and morale, and to public perceptions of and involvement in the process, it also enabled Zone Committee members to render unequal power relations visible. Communicative planning aspires to neutralise power, an impossible aim from a Foucauldian perspective (Mouffe, 2000). However, the CWMS' false promise of a politically neutral collaborative terrain was revealed when ECan deployed its regulatory standing and position as a coconvenor of the HWZC to constrain the agency of the Committee so it could progress the "more water" agenda. In suddenly exposing the power laden HWZC space in such a public and unexpected way, ECan rendered visible uneven power, and also unintentionally enabled individuals and NGOs to occupy a position from which they could act powerfully. Purcell (2009) contends that Habermasian planning offers a way to enrol those who resist neoliberalisms, while reinforcing existing power relations and the dominance of market logics. In this sense communicative processes can defuse and suffocate contestation (Ghose, 2005). Yet, by enrolling a range of people, including those who resist neoliberal logics, into a process based on principles of collaboration, claims to legitimacy within a democratically deficient context also come to rest in part on their continued participation. This opens the possibility for participants to enact collaboration differently and in potentially counter-hegemonic ways (Ghose, 2005), or simply undermine it through nonparticipation. The CWMS was developed by a broad spectrum of groups and people and its ability to continue to function as an extra-RMA body rested on the continued buyin of most of these people. While the HWZC's lack of regulatory standing meant ECan could override the collaborative process, it also meant that Fish and Game, other NGOs and members of the Committee, were in a position to abandon the HWZC and the CWMS more broadly, which may have caused each to collapse and reveal the highly tenuous nature of claims that there was meaningful environmental democracy in Canterbury. Further, as Fish and Game came perilously close to withdrawing, the work of maintaining a post political neoliberal nature, the constant suturing required to sustain consensus and suppress dissensus, was revealed, as was the fragility of the process. 
Ultimately, the people who indicated they had been close to walking away didn't. Environmental NGOs continued to support the CWMS and the application for a Water Conservation Order wasn't reactivated, as some had warned it might be. According to one participant, the decision to stay within the HWZC was made in light of the successes that had been made by the Committee (Louis 31 October 2011). Instead they chose to engage the media and the public to force ECan to be accountable (Max 22 February 2012; Caygill, 2011). The ECan principal planner indicated that this strategy did lead to reflection within the organisation:

I guess you would have seen the number of letters to the editor that got thrown into the newspaper, there was an editorial. There was an opinion piece that came out as well. All really bagging the process. So that would only have got stronger in my opinion if ... one of the Zone Committee members had walked away and we'd replaced them (Luke 29 November 2011).

Therefore, both on the Committee and in the public sphere, in direct contrast with ECan's attempts to channel outcomes more amenable to growth and land use intensification, the circumvention of the Committee proved to be a politicising act. Despite claims that postpolitics is characterised by the passivity of the masses (Swyngedouw, 2011b), the case study illustrates how people, even within a state of exception, can contest these processes and force a more responsive governing body. Despite the cavalier attitude of the ECan commissioner who viewed the fallout from ECan's interference as overblown, ECan staff, like the planner quoted above and the HWZC facilitator, did seem concerned about ECan's legitimacy and were responsive to the Committee and the public.

What these events highlight is that post-politics - disavowing conflict and politics, and channelling (neoliberal) outcomes - are processes (Chatterton et al., 2012). Understood in this way, a post-politics that requires constant work can, therefore, be troubled, interrupted, exposed and resisted. As Featherstone (2013, p. 57) states, exploring moments and processes of contestation 'emphasizes that the formation of a post-politics without antagonism is something that is achieved through active political strategies and the disciplining work of repressive policing and juridical frameworks'. Furthermore, a nuanced understanding of such processes creates space to acknowledge and further explore the achievements made in spite of and in resistance to post-politicisations, achievements that will be expanded on in Chapter 6. Yet most radical democrats describe 
a totalising binary between post-politics and authentic politics (McCarthy, 2013) that is related to dualistic, hierarchical constructions that favour universalising demands and struggles over local resistance (Featherstone, 2008). Although conceptualisations of postpolitical environments provide vital frames to analyse and critique changes in environmental governance, theorisations of post-politics should pay regard to wellrehearsed post-structuralist critiques that call for greater nuance in our naming of political processes (see for example Larner, 2003; Lewis, 2012; Peck \& Tickell, 2002). McCarthy (2013, p. 19), while acknowledging the utility of this frame for exploring environmental governance, states that characterisations of post-politics tend to be 'analytically flat, totalizing, and inadequate'. The totalising nature of this approach ignores, and risks marginalising, actually existing contestations and contributes to post-political common sense (Chatterton et al., 2012; Tambakaki, 2009).

The development and continued usefulness of post-politics rests on cultivating a more nuanced approach, in particular one that doesn't undermine resistance by dismissing everyday politics, and instead explores the multiple sites of resistance and reworking. The everyday nature politics in the Hurunui District will be further explored in Chapter 5. For the HWZC, the troubling of post-politics would not fit with Sywngedouw and Rancière's totalising approach to authentic politics. Yet it was through social learning, encroachments on private property rights, and illuminated power relations on the Zone Committee that the HWZC could begin to invite new environmental imaginaries into the space of decision making.

\subsection{Cultivating genuine environmental democracy}

Debate continues about the existing and latent potential of Habermasian collaborative approaches (Bond, 2011b; Purcell, 2009). Yet it is apparent that a suite of tools are required for political ecology analyses of collaborative environmental governance and the ways that democracy is constrained as part of ongoing neoliberalisations of nature. A post-political lens provides a frame through which to draw together and examine multiple processes that work to, and rely upon, the excavation of politics from nature. It is from such an examination that political ecologists might explore the legitimating function of deliberative processes in places with unstable democratic deficits (Purcell, 2009) and imagine more genuinely democratic processes in environmental governance. While such a 
reimagination may incorporate principles of collaboration, it is clear that improved environmental democracy requires explicit acknowledgment of unequal power relations and the value of contestation (Hillier, 2003; Mouffe, 2005) and makes hegemonies visible (Bond, 2011b). At a time of growing environmental instabilities, democratic theorists ought to extend existing analyses to explore how to dispense with post-political constructions of nature (Swyngedouw, 2011a), and reorient negotiations of the democratic paradox (Mouffe, 2000) away from excesses of human liberty and towards an equality that is inclusive of more than humans. Developing environmental governance that encourages participants to extend their commitments to more than humans raises further questions about political processes, questions which will be explored in Chapter 6 . Swyngedouw (2007), who has most clearly drawn together radical democratic theory and political ecologies, rightly argues that questions of how to live differently with the more than human world are actually questions of democracy - how can people reclaim space to question and debate different understandings of the relationship between nature and society? Yet in addressing these questions of democracy, geographers should be cautious about perpetuating hierarchical and totalising accounts of politics. Rather, a political ecology approach that incorporates a nuanced post-political lens is equipped to account for everyday contestations of power and moments of hopeful resistance and creation. Situated troublings of post-politicisations, as with aspects of the HWZC's work, complicate governance spaces orientated towards particular environmental imaginaries at a time when it's vitally important to contest damaging hegemonies. 
124 | Post-politicising processes in environmental governance 


\section{Community construction and performance - shaping the Hurunui River debate}

\subsection{Introduction}

Community has been increasingly privileged as a scale of decision making, and promoted as innately democratic (McCarthy, 2005). Within a Third Way context, local scales are viewed favourably as beyond political ideology, instead offering a way to make better decisions based on ethics (Rose, 2000) and localised knowledges. This turn towards community has been especially evident in environmental management as those that are close to and use resources have become progressively more responsible for decision making (Agrawal \& Gibson, 1999). However, devolving governance to more local scales has not simply equated to improved democracy or outcomes for nature and society (Walker \& Hurley, 2004). In practice, localised decision making has been complicated somewhat by unreflexive and uncritical understandings of "community" as close-knit units that share homogenous values. In contrast, critical community literature and feminist political ecologies have argued that communities are relational - community meaning is formed and performed between people - and require constant work to try to fix a collective identity (Bond, 2011a; Mouffe, 2005; Sultana, 2009; Watts, 2004). Understanding community as something that is constructed and performed has enabled examinations of the multiple and varying experiences of community.

Drawing on these critical bodies of literature, this chapter will explore how community meaning in the Hurunui District shaped the political space of the HWZC, a decision making body that was designed to privilege local community concerns and relationships with the Hurunui River, and resolve a "local" conflict. Identity and belonging in the District's 
environmental politics were determined through a hybrid assemblage of neoliberal and rural discourses. This assemblage established norms about how community should be performed, creating bounded spaces of "inside" for those who performed appropriately, and "outside" for those who didn't. I explore how "good" citizenship was based on individual local consumption and spatial membership, and also examine simultaneous processes that disciplined those who were "inside", but who dissented from instrumentalist approaches to nature. These disciplining processes were deployed through gendered behavioural norms, economic relationships, and exclusions from the social fabric of the District. Throughout, I demonstrate how community was constructed and performed in a way that worked to prevent a plurality of environmental imaginaries from entering public political spaces.

Through these complex processes of boundary making and policing, and internal disciplining, this chapter will explore the implications of privileging community as a scale of governance without critical consideration of how community is performed. Where previous chapters have focused on national, regional and catchment committee scales, this chapter draws on feminist political ecology to explore access to environmental governance through everyday social, economic and political life (Elmhirst, 2011; Sultana, 2011). In adopting such a focus, I contribute to an emerging area of political ecology that engages with the everyday experiences and negotiations of power within nature politics (Ekers \& Loftus, 2008; Loftus \& Lumsden, 2008; Peet et al., 2011). Moreover, attention to individual experiences reveals the everyday work that orders social relations and subsequently closes space for dissent (Raco \& Lin, 2012). Exploring the everyday labour that constitutes part of post-politicising processes suggests cracks and opportunities to creatively contest and resist the disavowal of politics. In response to claims that postpolitical theorisations are 'analytically flat' (McCarthy, 2013, p. 19) and have unduly focused on the state, this chapter builds on Chapter 4 in adding depth and nuance to existing characterisations.

\subsection{A critical approach to community based decision making}

As discussed in Chapter 4, a perceived crisis of democracy and simultaneous discourses about the limits of the state have seen scales of governance change in many contexts. New formations often illustrate a rejection of national society as the object of governance 
in favour of community (Larner, 2000b). Communities are increasingly promoted as preferable democratic scales as they are viewed as close-knit, definable groups that share values (McCarthy, 2005). Their supposedly close-knit nature has led to assumptions that communities are willing to help each other and actively participate in governance processes (Murdoch, 1997; Raco \& Imrie, 2000). As such, discourses construct communities as 'inherently democratic' and situated in contrast to states, which are associated with 'power and coercion' (McCarthy, 2005, p. 999). Yet with this amplified ability to define policy, communities are also increasingly assigned responsibilities that must be fulfilled to access and implement rights (Raco \& Imrie, 2000, drawing on Nikolas Rose). According to Rose (2000, p. 1400), localised populations undergo simultaneous processes of 'autonomization and responsibilization' whereby local populations gain more freedom to make decisions about their future, yet they are also allocated responsibility for their future and that of wider society. This "community turn" has been particularly apparent in environmental management (Agrawal \& Gibson, 1999), especially in majority world contexts (Dressler et al., 2010; Sultana, 2009) and decision making about freshwater (Morinville \& Harris, 2013).

Community-centric approaches to environmental decision-making initially gained favour in the 1970s and 1980s, alongside grassroots social movements, and rapidly took hold in neoliberalising contexts (Dressler et al., 2010; McCarthy, 2005). Agrawal and Gibson (1999, p. 633) argue that these approaches conceptualise community in three interlinked ways: 'as a spatial unit, as a social structure, and as a set of shared norms'. Theorised in a relatively fixed way, community has been endorsed as a tool for improving environmental governance. Some have posited that privileging communities as the locale of environmental management acts as an antidote to market and state dominance, particularly command and control planning (Li, 1996). In this sense, empowered communities offer the promise of more equitable outcomes than those generated by the (particularly (post)colonial) state or the market (see Dressler et al., 2010). In contrast to top down approaches, community based decision making involves people who have everyday experiences of the environment, and seeks to increase their understanding of environmental processes, while also capitalising on unique local (and often Indigenous) knowledges and values (McCarthy, 2006; Raco \& Imrie, 2000). Spatially specific knowledges are socially constructed and are often different to "expert" knowledge; in this way localised processes can potentially bring together multiple ways of knowing nature. 
Localised social networks are also seen to be important to building successful environmental governance regimes, as they may provide conditions that are more conducive to changing behaviours and practices (Broderick, 2005). Furthermore, in a list of five factors that improve the possibility of successful common resource governance, Dietz et al. (2003, p. 1908) argue that communities with dense social networks 'increase the potential for trust' and rule compliance (see also Cox et al., 2010). Under such conditions 'outsiders can be excluded at relatively low cost' as an effective way of protecting the environment (Dietz et al., 2003). Community, therefore, is a concept with significant public appeal and is deployed as 'a hope, a vehicle and a responsibility via which numerous social and political challenges might be overcome' (Welch \& Panelli, 2007, p. 349).

Yet "community" remains a highly problematic, and slippery, concept and tool (see Liepins, 2000b). Political ecologists examining the community turn have claimed that governance arrangements have been more complicated than first thought (Pratt, 2012; Watts \& Peet, 2004). Goldin (2013, p. 179) states that manifestations of environmental democracy that privilege community and localised participation have ignored 'leakages or incongruities that might thwart the comfortable logic that implies that more participation means more democracy and vice versa'. Some of the incongruities described include practices that work to contain difference within communities (Walker \& Hurley, 2004) or obstruct participation, for instance on the basis of gender (Barnes, 2013). Furthermore, rather than empowering people, devolved governance may simply reinscribe state and market power as those that are enrolled lack the capacity to contest state and market influence (Kadirbeyoğlu \& Kurtiç, 2013). In light of the complexities of devolved democracy, Mehta et al. (2001) have called for a rethinking of the concept of community within participatory decision making that rejects simplistic and uncritical notions that do not account for the plurality of norms and values, nor the exclusionary ways community is experienced as difference is suppressed or rejected. Indeed, such a rethinking has been cultivated in academic literature since the late 1990s, while planners have often continued to privilege localised practices of democracy (Brosius et al., 1998).

One branch of critical community scholarship draws on the work of Jean-Luc Nancy. An approach informed by Nancy rejects the possibility of communities based on sameness and a fixed identity because we are all defined by our strangeness and difference - we are all singular (Bond, 2011a; Welch \& Panelli, 2007). But we can only know we are different 
by being with others, and therefore 'being is always being-with' (Bond, 2011a, p. 782). Accordingly, community can be seen as a way of being that is articulated through the constant negotiation of singularity (our strangeness, uniqueness) and plurality (being with others, which is the only way to realise our singularity). Importantly, however, 'there is always a tendency to seek a fixed identity through commonality' (Bond, 2011a, p. 783). This fixing is attempted by excluding what is perceived to be a poor fit with the commonality, whatever that may be. Such exclusionary practices work to create bounded spaces of belonging, with an inside and an outside. Indeed Mouffe (2005), drawing on Derrida's ideas of the constitutive outside, argues that building a sense of identity depends on an "other", an outside. Community identity 'is relational and ... the affirmation of a difference is a precondition for the existence of any identity' (Mouffe, 2005, p. 15). This identification of difference does not necessarily mean a friend/enemy relationship, but relationships do have the potential to become antagonistic when the "they" is perceived as putting into question the identity of the 'we' and threatening its existence' (Mouffe, 2005, pp. 15-16). From these critical accounts communities can, therefore, be understood as multiple, unstable, and performed, rather than bounded units of governance based on shared values and norms. Meaning and identity are made in complex ways, at different scales, and community can be both reactionary and emancipatory, exclusionary and inclusionary (Watts, 2004). Communities are experienced and performed differently across time, space, gender, ethnicity and class as attempts are made to fix identity (Liepins, 2000b). These experiences are also affected by political, economic and social change at multiple scales (Apostolopoulo \& Pantis, 2010).

\subsubsection{Circulating power and community}

An understanding of community as performed, and holding exclusionary and inclusionary potential, necessitates a nuanced approach to power relations, an aspect of devolved environmental democracy that has remained under-theorised (Agarwal, 2001; Harris, 2011; Morinville \& Harris, 2013). As discussed in Chapter 4, Habermasian approaches to community decision making seek to neutralise power. This goal is, however, impossible as power is ever present, circulating and concentrating in different points at different times. Here post-structural approaches to power are informative, offering nuanced accounts of the ways that individuals internalise discursive norms. In contrast to notions of a fixed identity, post-structuralists are attentive to the subject, a shifting identification that is 
partly shaped by changing discourses (McKinnon, 2011) and hegemonies that establish what is normal (Robbins, 2012). Probyn (2003, p. 297) states that 'we are produced in distinct ways because of how we are positioned, how we are interpellated'. Here she refers to Althusser's work on interpellation, the idea that in a moment when a person is identified in a particular way, the subject of identification subsequently 'draws on a host of societal norms and expectations to understand themselves ... and becomes subject to the powers that decide what is right or wrong behavior' (McKinnon, 2011, p. 44).

Political ecologies have increasingly engaged with ideas about subjectivity to understand the complexities of power in influencing access to the environment and nature politics (Jones, 2008). Yet Loftus and Lumsden (2008) argue that while (specifically urban) political ecologies have successfully brought much needed focus to relations of power, the effects of these relations on the individual has been under-examined. Ekers and Loftus (2008) extend this focus on the individual and power within nature politics, asking how everyday relations form and support hegemonies, as well as challenge hegemonies. According to Peet et al. (2011, p. 41), political ecologies have increasingly focused on individuals' everyday experiences of hegemonic forms of rule because:

Understanding and resisting the way critical environmental problems are produced and promulgated in global capitalism depends on knowing and grappling with how people internalize, narrate, and explain the world around them.

This chapter will contribute to this emerging area of focus within political ecology, as well as critical accounts of community by exploring an example of how community is made and performed. To do this I chart how a hybrid assemblage of discourses (Larner, 2000b; Li, 2007) established certain social norms that shaped community belonging. This approach also draws on feminist scholarship that links informal spaces and practices, such as community construction, to formal political processes charged with determining access to nature (Staeheli et al., 2004).

In particular, I examine how community belonging and community behavioural norms closed spaces for political dissent and debate in ways that sought to channel the neoliberalisation of nature. Such closure is indicative of post-politicising policing whereby existing social relations are maintained and social space is ordered (Swyngedouw, 2013b). However, Chatterton et al. (2012) argue that to date studies of these policing processes 
have given undue focus to the national scale. Further, Raco and Lin (2012) state that accounts of post-politicisations largely characterise such processes as top-down, leading McCarthy (2013, p. 19) to claim the body of literature is 'analytically flat'. In the following I address these gaps through a grounded example of everyday policing of environmental debates, deployed through performances of community. A feminist political ecology lens that interrogates how forms of difference shape access to the environment is woven throughout the analysis (Elmhirst, 2011; Rocheleau et al., 1996b).

The following section will describe how constructions of community belonging and citizenship in the Hurunui District, and norms of community performance, were experienced across forms of difference including race and gender, before exploring what these experiences meant for debates about the Hurunui River.

\subsection{Experiencing community across forms of difference}

\subsubsection{Seeking economic autonomy - rural discourses of independence}

Agriculture was one of the first industries to experience the severity of neoliberal reforms in Aotearoa New Zealand. After the Labour Government was elected in 1984, they set about removing farm subsidies, which in the early 1980 s had constituted up to $50 \%$ of sheep and beef farm incomes (Le Heron \& Roche, 1999). This was the most rapid reduction in support for agriculture experienced anywhere in the world, and many families had to seek off-farm income sources, while others lost farms through debt and rising costs (Le Heron \& Roche, 1999). Simultaneously services supported and provisioned by central and local governments, such as health care providers and post offices, retreated from rural areas, and both publicly and privately employed workforces were downsized for increased efficiencies (Pomeroy, 2011b). As employment and study opportunities declined in many places, and transport improved, people migrated out of rural areas, particularly young families and young people (Pomeroy, 2011b). Furthermore, as services were withdrawn and centralised, individuals and rural communities were expected to fill the void and take greater responsibility for the well-being of themselves and others, for instance in caring for the elderly (Joseph \& Chalmers, 1998). The effect of agricultural and broader state reforms created a somewhat paradoxical space in which traditional rural commitments to liberty (Woods, 2006) and narratives of independence and self-reliance 
(Pomeroy, 2011a), were confronted and challenged by, what was for many, the tough lived experiences of policy change (Johnsen, 2003). Some ruralities, however, were able to diversify agricultural operations, and successfully navigate international markets resulting in population growth and improved financial viability (Pomeroy, 2011b).

Since these initial reforms, growth through neoliberal technologies has remained at the heart of central government policy making. For the Labour government in office for much of the 2000s, continued economic growth was largely sought through building a creative knowledge economy (see Roberts, 2009). But the election of a centre right National-led government in 2008 , traditionally supported by a farmer voting bloc, saw a reorientation of the growth agenda towards primary industries, particularly mineral extraction and agriculture (see, for instance, Rudzitis \& Bird, 2011). As described in Chapter 3, this instrumentalist approach, whereby nature is primarily valued for its revenue generating capacities, has often led to a reregulation of the environment to enable economic growth.

Within this national political economic context, many residents of the Hurunui District sought to secure more irrigation for economic growth that would improve living conditions within the area (Field notes 20 September 2010). In the face of sometimes difficult farming conditions, research participants reported out-migration from Hawarden and Waikari. A report by Pomeroy (2011b) illustrates a significant "hollowing out" of young people from the District between 1981 and 2006. Out-migration created a surplus of housing and cheaper accommodation that, in the view of one participant, attracted social welfare beneficiaries (Allan 17 November 2011) who weren't viewed as particularly desirable community members. One resident stated, 'there's cheap rents ... and we're getting, you can't call them undesirable can you? But lower socio-economic ... there's a lot more people with records and people that you don't need around the place' (Hamish 11 August 2010).

In addition, the small school roll was seen by the principal of a local school as a barrier to offering an educational experience that included a broad range of subjects and diverse social contact (Allan 17 November 2011). Some residents were also concerned with creating job opportunities that would attract and retain young people (Allan 17 November 2011; Nick 17 November 2011), particularly given the growing youth unemployment rate in Aotearoa New Zealand and discourses that situate work as the avenue to full community membership (Ministry of Business Innovation and Employment, 2012; Rose, 
2000). Many residents of the area were determined to develop their own, District based solutions to these issues through the HWP. HWP was formed as 'a way to improve welfare for the entire community' (Hurunui Water Project, n.d.). Increased irrigation was viewed as the best 'avenue for us as farmers to ensure that the next generation of farmers can stay on the land' and in the area (Nick 17 November 2011). This view was fuelled by the success of Culverden, a town in the Amuri Basin and just a twenty minute drive from Hawarden, that had secured irrigation in the 1980s. One interviewee who farmed near Culverden described how the contrasts in water availability had shaped the fortunes of the towns:

I think it's probably split along two, the Zone's split into two basically. You've got the Amuri Basin area where the dairy farming is, and that's sort of one community. We've got the fairly high economic inputs and development and we're reaping the rewards of the water there. And then you've got the Hurunui area, predominantly south of the river where they haven't got access to water so the economic status down there is quite poor and a lot of those farmers would be struggling. And in some ways I think you could say it's an us and them type of scenario where we've got the water, we've got the development and now this other area around the Hurunui need the development as well (Brad 5 November 2010).

Culverden has a number of commercial enterprises associated with the highly productive dairy farms in the area (Pomeroy, 2011b). Furthermore, dairy operations require more labour than sheep and beef. However, rather than young, locally based people filling labour requirements around Culverden, a large proportion of farm workers are immigrants. Pomeroy (2011a) reports that many rural communities in her study appreciated the increased diversity brought by international immigrant workers, as well as the contributions they made to local institutions such as sports teams. However, this diverse workforce highlights the contradictions of District desires for more water; the long, unsociable hours of working on dairy farms, and often poor working conditions, mean that it is hard for the industry to attract and retain young Aotearoa New Zealanders. Many of the immigrant farm workers are attracted by wages higher than in their home country, and are favoured by employers because they are tolerant of the work conditions (Tipples et al., 2010). 
A number of water storage advocates also felt a great deal of responsibility to contribute to the national economy and cater to the social needs of all Aotearoa New Zealanders (Arthur 23 November 2011; Victoria 22 November 2011; George 11 August 2010). In order to meet these needs, one Zone Committee member stated that water storage for irrigation is:

the only option we've got, that New Zealand's got. We've got such a variable climate and rainfall, New Zealand is basically a net exporter of protein, and for the country to generate the GDP required to maintain the country as it is, we need these types of projects to go ahead, to increase GDP, employment and, basically fund all of the social benefits etcetera that are out there (Duncan 4 November 2010).

The desire to seek their own solutions to ensure the continued survival of the Hawarden Waikari community was indicative of rural narratives of 'community self-efficacy', the ability to successfully solve problems (Pomeroy, 2011a, p. 63). Pomeroy (2011a) notes that desires for community ownership of decision making, and a lack of trust in government regulation, were particularly apparent in her research with rural communities in North Canterbury. The "more water" vision for economic growth, and its promise of an independent, economically and socially vibrant District that contributed to the national economy, rested on the production and reproduction of a particular kind of nature - one that is valued primarily on an economic basis.

Many proponents of irrigation did understand nature in complex ways that extended beyond narrow instrumentalism, and most of those interviewed described the need for a degree of care for freshwater bodies and ecosystems. For instance, an irrigation advocate and farmer in the Hawarden area described growing up next to the Hurunui River, stating:

It's a big part of our lives, the Hurunui River, it always has been. Like we always used to go there as kids, swimming in it, raft races on it, so we've grown up in and around it. I mean, it's our local river at the end of the day so we're pretty keen to look after it. But in saying that we realise that it's a resource that potentially can be used to better this area. I think that's something we've got to understand around here is that some of the best soils in Canterbury are in this area, for 
growing crop produce, but at the end of the day it's all limited by water (Nick 17 November 2010).

The Mayor of the District, a strong advocate of large scale storage, stated that he understood the perspectives of dam opponents because of his own connections to a river that was also subject to dam proposals (Field notes 31 January 2011). He described growing up next to that river, stating:

That was our playground when we were kids and to me that's significant and I'd regard that as local for me, even though I live in Hurunui now and have for forty years. The importance of something like that is still strong enough for me to say, "hey, don't you destroy Ashley Gorge by putting a dam on the valley and then putting a whole lot of water down and wrecking that" (Donald 21 February 2012).

He went on to state that dam advocates are simply 'doing what they need to do for their survival' (Donald 21 February 2012), and enclosing nature for economic growth was seen to be the best hope for sustaining the area. Community self-reliance and vibrancy was more important than an 'untouched' river (Nick 17 November 2011). Furthermore, a dam was often promoted as a way of "improving" nature as people could control the flows when the river was low, and 'flush and dilute' contaminants when nutrients accumulated (Field notes 18 April 2011).

However, as already noted, the "more water" imaginary was contested. A number of people disagreed that irrigation was inevitable, and rejected the need for large scale water storage, and there were an array of reasons for this opposition. One woman resisted proposals to dam the Hurunui because she had lived her whole life beside it, and many of her family memories were tied to the river (Ruth 24 November 2011). Another person described how the river was woven into broad hydrological cycles that couldn't be fully understood, were beyond the scope of western science, but that played important roles in the biophysical world (Moana 22 November 2011). For some, the river formed part of the commons and belonged to everyone in Aotearoa New Zealand (Ben 14 November 2011). Furthermore, having 'untouched' rivers was vital for the 'country's psyche' and wellbeing (Louis 31 October 2011). People described being "re-created" with the Hurunui River being with the river was regenerative and affected them in ways they found difficult to articulate (Ben 14 November 2011; Joanne 5 November 2011). One participant described 
the affective dimensions of interactions with, and the liveliness of, the river (see Chapter 6) stating:

it's just an amazing feeling being there and darkness falling and the river rushing by and people just being by the river. It's very, very special. I'm very, very wary of the Hurunui River. I never, ever want to swim in the Hurunui. I'm always careful of the Hurunui River. But I'm very aware of what an amazing privilege it is and how incredibly lucky we are (Julia 28 November 2011).

Henry, a kayaker, described the Hurunui and Waiau rivers as family members:

I paddle all over the place but I keep coming back to those two places. They are my home, they are part of my family as far as I'm concerned. If I see them threatened, I'll defend them. Why would you not defend your family? I don't know anyone who's any different (Henry 1 November 2011).

These understandings of the relationship between nature and society, and many other imaginaries in existence (including those of Ngāi Tahu detailed in Chapter 6), that valued the river beyond its economic potential, motivated people to resist on-river damming.

While many avenues for resisting on-river storage were circumscribed through the ECan Act (see Chapter 3), possibilities to trouble the progress of storage proposals existed in informal spaces through activism and resistance, as well as through the HWZC as it designed the foundations of the Hurunui Waiau River Regional Plan. In the face of these threats to storage and, therefore community survival, practices in the Hurunui District policed the public visibility of non-instrumental nature/society discourses. These practices shaped the possibilities for subjectivities to appear in the public sphere (Butler, 2006), and what could be seen and heard as rational and legitimate (Rancière, 2001). The following two sections will explore two means of policing difference - exclusionary notions of citizenship and belonging, and disciplining through gender norms and social life.

\subsection{Sites of discipline - good citizenship in a neoliberalising rurality}

Notions of belonging, or citizenship, to the Hurunui community and subsequent rights to participate were one means of shaping the appearance of dissent. Like community, citizenship is not a static concept. Rather it is constructed differently across time and 
space and is subject to circulating relations of power. Recent constructions of "good" citizenship, informed by neoliberalisms, have been based on norms of the self-responsible, active, consumer citizen (Woods, 2006). Access to full community citizenship in neoliberalised contexts is increasingly dependent upon 'merit and deservedness (ie responsibilities)' (Brownlow, 2011, p. 1271) which is judged according to productive behaviour that contributes to the economy (rather than, say, to a household), cares for self and family, and avoids state dependence (Ghose, 2005; Larner, 2000b; Roelvink \& Craig, 2005). In the context of Aotearoa New Zealand, Larner (2000a) contends that economic qualifications to citizenship have increasingly displaced broader notions of social citizenship, which imply rights and responsibilities that flow from attachment to society.

In the Hurunui Waiau Zone, good citizenship was a key requirement to be able to access environmental democracy. A number of people in influential roles sought to qualify participation in water use debates and decision making according to conditions of merit, particularly merit that was defined by active local consumerism. There was a clear perception that if people didn't take part in the area's economy in certain ways, they weren't entitled to contribute to decision making about the Hurunui River. For the District Mayor, participating in the District economy as a consumer was imperative if people wanted to have a say in the future of the Hurunui River:

Hundreds of people come up there for the weekend and they come up, they fill their car with petrol in [Christchurch], they bring their lunch with them, so they drive up there, have an enjoyable day and drive home again and they don't take part in the local community. They don't make any contribution to the local economy. The local people maintain the roads for them, we have to put in toilet facilities and that sort of thing, and yet the people that come in and demand the use of [the river] don't make a contribution. So there's resentment for that sort of behaviour. If people stopped and had a meal and filled their petrol tank up at the local garage and whatever, that would all help to say "hey, we're making a contribution to your community" (Donald 21 February 2012).

This caveat to participating was shared by the HWZC chairman who stated, 'interest groups fly in today, on Saturday, and fly out Saturday night, basically don't contribute anything to the local economy unless they're a paying tourist' (Brian 1 February 2011). This narrative is indicative of neoliberal reframings of the relationship between nature and 
society. Bakker (2007) describes the way in which rights to the commons are reworked as commodity use rights afforded to individual consumers. Rather than broad public rights to access the environment, the relationship between nature and society is increasingly performed through the economy, here through individual consumption in the District.

However, articulations of good neoliberal environmental citizenship also synergised with rural discourses of belonging as spatially defined. While Brownlow (2011, p. 1271) contends that neoliberal citizenship is associated with the declining importance of rights accrued through 'spatial membership', understandings of belonging in the Hurunui District were discursive assemblages that drew on dimensions of both ruralities and neoliberalisms. Notions of rural community as inherently spatial and place based (Cloke \& Little, 1997a), in contrast to communities of interest for example, constitute a demarcation of the "other" against which to form an identity. Resistance to water storage was viewed as largely coming from outside the Hurunui District, from 'city people' (Hamish 11 August 2010) and national groups such as Whitewater New Zealand and Fish and Game, who had previously applied for a Water Conservation Order. To the chairman of the Hurunui Water Project, also a HWZC member, attempts to be involved in decision making by people from beyond the district boundaries, who didn't contribute to the local economy, were considered illegitimate (White, 2010). At a 2011 meeting, he argued that 'people who live, work and pay rates in the Hurunui District have had little meaningful input at this stage, compared to interest groups and communities outside the District' (Hurunui Waiau Zone Committee, 2011c). In contrast, the chairman of the Zone Committee thought that the CWMS had usefully re-placed focus on the 'community who lives and works there every day' (Brian 1 February 2011, emphasis added). In both instances, those who work, pay rates in the District and live inside spatial boundaries, are seen to be the people that should have the most control over decisions about the Hurunui River.

Neoliberalised rural discourses of good citizenship also pervaded some understandings of how Māori should participate in environmental decision making. While the Mayor recognised the important role of rūnanga on the Committee, and stated they were 'critical and valuable' to the HWZC (Donald 21 February 2012), he viewed Māori as performing a citizenship based more upon rights to the environment than good economic participation, stating: 
it was their hunting ground, I guess, 200 hundred years ago but today there's a certain amount of resentment that they have so much influence over what we can do and can't do, and yet they make no contribution - they pay no rates, they don't live here, shop here, play sport, they don't do anything apart from demanding that that environment is there for them when they want it, and they want it in the condition they want it. So those are the sort of things I guess that have been quite difficult to handle as "local locals" [people living in the Hurunui District] (Donald 21 February 2012).

Donald's understanding of the role of rūnanga in making decisions prioritises considerations of economic contribution over a recognition of Indigenous rights and relationship of partnership with the Crown and Crown authorities (Howitt et al., 2013). When competing understandings of a smaller river in the area arose, Donald resented the potential barrier to economic growth in the community. At a February 2011 meeting, rūnanga representatives argued that the Waipara River needed to be cared for in such a way that there would be enough water flowing down to keep the mouth open, and thereby enable customary practices and food gathering. However, there are a number of grape growers in the Waipara area who have water takes. Donald saw the rūnanga position as encroaching on the wine industry, and its ability to create jobs, stating:

the rūnanga want to deprive those landowners of the water that they're taking to irrigate, just to enhance or reinstate the mouth and the lagoon for their benefit. So the demands that they're making on that river cut across the ability of the local community to have an economy and create jobs and all that. So there's a lot of tension there (Donald 21 February 2012).

Rūnanga navigations of their understandings of nature and economic growth are described in Chapter 6, as are the tensions over Māori representation within District environmental decision making. Within the broader discussion of neoliberalised citizenship in this chapter, it is significant that within a neoliberalising context Māori have been both unevenly affected by reforms, and able to act powerfully within the changing political economic landscape. As the "New Zealand Experiment" took shape, Māori were disproportionately represented in the sectors that suffered heavy job losses under reforms (Kelsey, 1995). The subsequent retractions of social welfare were also therefore felt acutely by Māori (Durie, 1998) and inequalities have been entrenched within Māori 
communities through ongoing neoliberalisms and (post)colonialisms (Robson, 2007). Yet it was in the late 1980s and 1990s that Māori established a greater degree of autonomy as they asserted their status as tangata whenua, which was and is still being affirmed by the courts and through the Treaty settlement process. Through this process, claims are lodged by iwi and settled with the Crown, with agreements incorporating, for instance, naming rights, cash settlements, and first right of refusal in Crown asset sales (O'Regan et al., 2006), in addition to a range of new governance arrangements (for instance, see Ngai Tūhoe, 2013). Jackson (2005) argues however that discourses surrounding the Treaty and the settlement process also reaffirm the subjection of Māori and legitimise colonialism, as issues of sovereignty and constitutional change are not addressed (see also Bargh, 2007).

Nevertheless, within the context of Treaty settlements, Māori were at times able to act powerfully and interrupt, resist, alter, and capitalise on privatisation processes (O'Regan et al., 2006; Prince et al., 2006). Further, as government services were outsourced, Māori became increasingly involved in service provision for Māori, by Māori, although many structural barriers to accessing services have remained (Robson, 2007). MacDonald and Muldoon (2006, p. 213) argue that the combination of the Treaty processes and neoliberalisms 'provided the space and rhetoric for an emerging sense of Māori citizenship, whether antagonistic to, or desiring reform of, the New Zealand state'. Importantly, however, experiences of Māoridom, citizenship, neoliberalism and settlement are very uneven; there is no homogenous Māori community.

For Ngāi Tahu, settlement with the Crown came in 1998, and some viewed it as providing the necessary economic standpoint from which to assert rights to self-determination (MacDonald \& Muldoon, 2006). For the Te Rūnanga o Kaikōura member appointed to the HWZC, this ability to perform powerfully in the economy has been pivotal as Ngāi Tahu has sought a greater role in environmental management (for example, see Radio New Zealand, 2013b). In the Hurunui District, Ngāi Tahu Property looked to develop Balmoral Forest, next to the Hurunui River, into dairy farming operations as a means to increase returns from their land holdings (see Chapter 6 for more on iwi structure and commercial interests in the Hurunui District). A representative of Ngāi Tahu Property also stated that working toward irrigation provision in the District was important to 'sustain that community' (James 29 November 2011). Te Rūnanga o Kaikōura's HWZC representative stated that the iwi's commercial portfolio made wider society more receptive to Ngāi 
Tahu, but recognised the problematic, narrow nature of recognition that rests on economic performance:

I think ... the reality is that when you've got a commercial arm that's gonna spend a lot of money in that community, that kind of, I hate to say it but it kind of tends to make some people a bit more receptive as well. I mean, I know that from Kaikōura with Whalewatch [a successful Ngāi Tahu business], you know that really opened the door. We sort of had to get commercial nous before we could really push that door open. And unfortunately, with some people that's how they measure you (Joyce 15 February 2012).

The requirement that the iwi spend money within the area in order to participate in debate about water bodies in the Hurunui Waiau catchment area represents a barrier to accessing environmental decision making, and reinforces uneven (post)colonial power relations (see Chapter 6).

Hurunui citizenship was an assemblage of ruralities (that rested on bounded space) and neoliberal discourses (that emphasised economic responsibilities as a qualification to democratic rights). As a result of this construction and its performance, it was particular subjectivities that could claim full citizenship and participate in processes of decision making (Bulkeley et al., 2007).

\subsubsection{Sites of discipline - the home and a changeable social fabric}

However, not all resistance to dam development could be so easily excluded according to spatial demarcation or economic performance. Representations of rural life have been 'idealized' as people living within an 'idyllic and problem-free environment' (Cloke et al., 2000, p. 116), consisting of close-knit groups possessing homogenous value sets (Cloke \& Little, 1997b; Panelli et al., 2004). Yet, there were a number of residents inside the District that challenged the rural idyll through their opposition to dam storage, and therefore, the vision of growth through irrigation. In the face of this opposition, disciplining practices were deployed that held the threat, sometimes realised, of exclusion from the social fabric of community. This internal discipline was carried out through everyday relationships, policing the appearance of politicised subjectivities. 
One form of everyday policing took place through gender norms. Feminist geographers have highlighted essentialising expectations that women perform as nurturers of human bodies, especially those of the people to which they are kin (Cameron \& Gibson-Graham, 2003; Kobayashi, 1994; Nast, 1994). There is also substantial literature exploring how gender is situated through rural life in ways that reflect and reinforce uneven gender relations (see Little \& Panelli, 2003). The norms flowing from these relations, underpinned by family and farm life, are particularly apparent for women in rural Aotearoa New Zealand. While neoliberalism in Aotearoa New Zealand has been associated with considerable advances for women (Larner, 2000a), Liepins (1998, p. 375) argues that performing well continues to be linked to the 'support and material provisioning of the farms' family members'. In the Hurunui Waiau Zone the effects of these norms on political participation were made visible by the experiences of one particular research participant. Julia had moved to the District decades prior and was a vocal opponent of water storage on the Hurunui. She had worked as a key service provider and, through her own distance from gender norms around provisioning for farms' family members, sought to extend and empower other dam opponents. As such, she performed a pivotal role as a confidant for other women in the area who shared her views about water storage, yet who did not or could not access public debates:

I've spoken to a number of usually female partners of farmers, who have approached me when I've written a letter to The Press ${ }^{25}$ or something, and said that they support me wholeheartedly but it's more than their relationship with their husband and their social friends is worth to come out and openly say that (Julia 28 November 2011).

Farm-based women speaking out against dam development would represent a subversion of claims that irrigation was the best way of achieving a vibrant community. The construction of the debate as one of continued community survival meant that the stakes were high for women who were expected to behave in a way that supported and nurtured kinships. In this sense, political debate was policed through gendered norms as women felt limited to speak in opposition to their family members. In the face of the constraints on their ability to publicly participate, Julia tried to support and empower women who

\footnotetext{
${ }^{25}$ The Press is the main daily print publication in Canterbury.
} 
were experiencing the effects of policing. She placed a notice in a local school's newsletter, inviting anyone opposed to the dam, and who felt 'anxious or unable' to speak publicly about it, to contact her confidentially to discuss their concerns:

I didn't get a huge response but I certainly got some response, and I don't know how many people responded but all of them were women married to farmers. I asked if they would speak up at meetings but they can't. People who I know vote Green, who in any private conversation with me will express their hesitation about what's proposed, can't do it, do it openly (Julia 28 November 2011).

Experiences of community reported by the participants highlight the need to address the multiple scales at which power circulates and is deployed. In their landmark feminist political ecology text, Rocheleau et al. (1996a) argue that access to the environment is deeply gendered, and since the publications of that text, a significant body of work has emerged exploring the intersections of gender and the environment (Harris, 2009; for an overview see Hawkins \& Ojeda, 2011). Yet Sultana (2009) identifies a need for much more gender analysis of participatory community based environmental decision making, in particular to challenge assumptions that such processes will necessarily address inequalities. Indeed, in the Hurunui District, the debates about nature are revealing of the persistence of uneven access to decision making forums.

Disciplining was also performed more broadly through social life, as friendships and economic relationships were retracted according to differing opinions about water storage. Liepins (2000b) calls for greater attention to the ways community meaning is performed through economic, political and social lives. In the Hurunui District, everyday life was a key locale for performing and policing community. For one interviewee, precarity of belonging to the community was experienced through economic life, as dissent was disciplined through class and an economy that rested on agriculture:

Amanda: So it's not easy to voice dissent?

Ruth: No, I'll tell you why. I learnt very young that it is not easy in a rural district unless you have a secret vote, because if you are in a village and you don't like what is happening, you are employed by usually the biggest person in the village or the farmers outside the village. So if you are in the village and you say no to 
something, the farmer can say, "I don't want that guy coming on my place", to the local truck owner ....

Amanda: So, it's tied in with the economy, they use the economy to silence -

Ruth: Oh they use the economy to destroy people (Ruth 24 November 2011).

Ruth went on to describe how she had always sought employment outside the District to avoid being disciplined for her environmental politics. She stated that she simply couldn't have had a career in the area because of the way economic relations were enrolled against difference and dissent.

For others, it was the threat, or reality, of a changed social life that shaped how they experienced community. Argent (2008) argues that in rural areas social contact is a vital component to feelings of belonging and morale. So while Julia was unequivocal in her opposition to the dam, she was fearful that social relationships would be withdrawn as a consequence. When I asked her if there was a personal cost to dissenting from the dominant view in the area, Julia stated:

Yes! But once you've actually crossed that barrier it's easier. Once you've taken the jokes and the flak and the odd unpleasant comment, in some ways it's a nice position to be in. I don't need to hide. And in a way you feel just by having identified your position ... it's sort of a rallying point ... [B]ut I also terribly want to get on with this community because it's my life support system really (Julia 28 November 2011).

One participant, who had always lived in the District, described how people feared being heard opposing a storage scheme that many people around Hawarden were heavily invested in financially, stating that there were certainly 'elements of intimidation in the community' directed towards dam opponents (Short interview 8).

The kind of isolation Julia feared was realised by one couple who, as a direct outcome of the debates about Hurunui River use and their role organising and taking part in a range of actions and protests, reported that most of their friendships within in the Hawarden Waikari area had disintegrated, with one of the couple labelling it a 'bullying community' (Ben 14 November 2011). Ben described an 'inarticulate pressure to conform' that was exacted through social relationships. In social and political situations, he and his partner 
were avoided and ignored by people they knew well, but who disagreed with their water politics or didn't want to be seen talking to or even acknowledging them in public. Ben reported one incident where the then Minister for Agriculture and Forestry was scheduled to hold a meeting in the Hawarden Waikari area soon after the ECan Act had been passed. Ben had been involved in a number of actions in response to the legislation, and he recounted how the day the Minister was to arrive in the area the local policeman drove up to his house:

He's the local cop ... and his wife was our midwife, you know, we know each other. [He] jumps outs and he's got a big grin, and I said, "cup of tea?" "Sure." So I made the pot, took it down to sit at the table, have the cup of tea. And I'm about to pour it ... and I said, "hold on a minute, are you here on business or pleasure?" He says, "that depends", I said "on what?" He said, "are you going to this meeting tonight?" (Ben 14 November 2011).

This encounter represents the policing of water politics in both the formal sense, and in the sense of patrolling the public appearance of different environmental imaginaries. In both ways, work was done to limit the public sphere to already existing framings of social and environmental issues (Swyngedouw, 2013b). This treatment of difference and dissent is certainly not a new phenomenon (Prout \& Howitt, 2009). Cloke and Little (1997b, p. 7), drawing on Edward Said's work, state that processes of identity formation in ruralities are:

subject to forms of internal colonisation .... in that the discursive formation of the rural rests on a complex hegemony of domination which both materially and culturally constitutes an acceptance and belonging for some, and a marginalisation and exclusion for others.

Such experiences are common to any type of community that seeks to fix identity. The internalisation and enforcement of gender norms and the threatened and real collapse of social and economic lives are not novel. But analyses of how these processes work to close spaces for debate about the environment are currently lacking (Chatterton et al., 2012). These links will be explored in the following section. 


\subsection{Narrating everyday post-politicisations}

Evident throughout the examples offered above is the manner in which the construction and performance of community placed limitations around what could be said, what kind of subjects were seen as legitimate political actors, and what could be heard and understood as legitimate (Butler, 2006; Rancière, 2001). Julia described how policing of difference affected her willingness to contribute to decision making processes:

I felt very bullied once at a meeting, it wasn't actually a Zone Committee meeting, although most of the Zone Committee was there. It was a community meeting up at Hawarden ... it's difficult to voice these opinions when maybe only five people in the meeting share similar views to you and the rest are landowners who've already bought into the Hurunui Water Project [as shareholders] and there are maybe thirty of them, sitting, glowering at you. It's scary and it's intimidating (Julia 28 November 2011).

The experiences of intimidation reported to Julia by women in the Hurunui District, and experienced by Ben, Ruth and others, represent the implicit and explicit attempts by people subscribing to hegemonic nature/society discourses to close off the possibilities for democratic public debate. Raco and Lin (2012) state that there are few explorations of post-politicising processes that identify the how and why. It is not my intention to demonise those who acted to police water use debates. Rather I have sought to explore how people were motivated by community survival, influenced by rural desires for economic autonomy and shaped by neoliberal discourses of inevitability, and how these discourses underpinned constructions of community belonging (Mouffe, 2005). People living in Hawarden and Waikari compared their material conditions to those of Culverden, and wanted these same opportunities for a vibrant, economically autonomous and selfreliant area based on water storage (see above).

Narrating experiences of and motivations for post-politicisation highlights the everydayness of efforts to disavow dissent and conflict, and the effect on people and their agency. As argued in Chapter 4, these processes are never complete and are subject to interruption, subversion and creation. While Julia certainly felt pressure to conform, she attempted to use her position as a 'rallying point' to act powerfully to enable others to feel a sense of agency. Ruth, who identified the coercive potential of class and economic 
life, organised a petition opposing a dam that people could sign anonymously. She was no longer reliant on the district economy for her material survival so was able to attend and participate in most HWZC meetings. She was also linked into strong networks that had been forged in the face of the proposed dam and weir, particularly as dissenters were ostracised from some social groups in the district. Ben (14 November 2011) stated that 'the beauty is though, when you start fighting, we lose friends, but we make new ones. And the people we've met in the last two years are extraordinary'. These friendships were formed outside the District, and as well as being important on a personal level, these social networks were used to resist the dam in spite of the boundaries of belonging, and processes of disciplining, that worked to exclude them from decision making. One Christchurch based activist described an extensive network of dam opposition, stating:

There are a very wide circle of people on the outside who are interested in the area and in particular to conserve it. I mean we've built an organisation which is the biggest pressure group since the Springbok Tour ${ }^{26}$ in Christchurch as far as we can make out. People are interested. We send out emails, we send out notices, people respond. And then there's probably an inner circle who try to follow the minutiae of it, of who said what, what regulations are being responded to, how the Zonal Committee is voting, how the commissioners are responding, all that (Louis 31 October 2011).

Examining the labour of post-politicisation and the day to day experiences of these processes defies characterisations of a post-political "consensus" or "condition" (for instance Mouffe, 2005; Swyngedouw, 2007), a diagnosis that leaves few openings for enacting a different kind of politics or acknowledging those that already exist (Featherstone \& Korf, 2012). Rather, focusing on the work of situated post-politicising processes is suggestive of further spaces and means for contestation (Chatterton et al., 2012).

\footnotetext{
${ }^{26}$ In 1981 the South African rugby team, the Springboks, visited Aotearoa New Zealand to play against the All Blacks, the national side. The tour was met with significant protest, and resulted in self-analysis of Aotearoa New Zealand's own race relations. The Springbok Tour is seen as a very significant event in national history. The protests in response to the tour were national in scale; in making this comparison between freshwater activism and the Springbok protests, Louis is referring to regional politics specifically.
} 
Processes of policing and closure, and how people attempt to resist them, have important implications for how we understand community, in particular the extent to which community performance can shape environmental democracy. The following section will examine the effects of policing on the HWZC, and both the successes and failures that flowed from the way community was privileged in the Hurunui Waiau Zone.

\subsection{The effect of bounded notions of community on political spaces}

Charting processes of boundary making, policing, and disciplining, is revealing of the risks of privileging community as the best scale for democracy. Rather than empowering people, community as the location of environmental democracy may, at times, act 'more as a mechanism to reproduce particular political rationalities and programs through discourses, models, and practices of citizenship that regulate individual behaviour' (Masuda et al., 2008, p. 362, emphasis added). Research participants' experiences of behaviour regulation and subsequent barriers to accessing political spaces indicate how the Canterbury Water Management Strategy privileges "local" communities and fails to adequately engage with difference. The Strategy was established in part to ensure 'community and economic wellbeing' through locally-based decision making structures (Canterbury Mayoral Forum, 2009, p. 15). Scale was important in the design of the Strategy, as catchment based zones were seen to be 'small enough to avoid becoming remote from local catchment issues or allowing people from outside the relevant area to have a say in matters that are not directly related to their interests' (Canterbury Mayoral Forum, 2009, p. 9). While the intention of this scalar design was to involve river users in decision making, in practice when combined with its established goal of "more water" the CWMS adopted 'a vision of community as bounded, homogenous, local and designated to a particular 'user group', neglecting questions of social difference and the diverse, sometimes conflicting, concerns of resource users' (Mehta et al., 2001, p. 3). Furthermore, this vision reflects neoliberalised notions of community as 'natural', 'extra-political' (Rose, 2000 , p. 1400) and the logical location for enhanced democracy. Neglecting the politics and difference inherent to communities was not conducive to a nuanced engagement with the diverse values, desires, and goals that existed in the Hurunui Waiau catchment.

The HWZC, in putting the CWMS into practice, undertook a degree of work well beyond what was initially indicated and at a frenetic pace in order to meet the deadline to 
produce their ZIP within a year (see Chapter 4). This workload served to further prevent critical engagement with the concept of "community" or the way the CWMS privileges the local. While some members stated that the time constraints were beneficial in producing decisions and outcomes (Brad 21 February 2012; Brian 16 February 2012), no one had expected the degree of work and commitment that would be required as a result. Indeed, these demands on volunteers resulted in the first representative for Te Rūnanga o Kaikōura resigning in September 2010 (pers comms Rob). Committee members reported that their work had exacted a cost on family life, businesses, and personal time (Brad 21 February 2012; Tim 14 February 2012; Shona 18 March 2012; Field notes 14 March 2011). At one meeting in May 2011, almost all HWZC members identified the limited timeframe as a central flaw of the process to that point (Field notes 30 May 2011). They were paid an honorarium for travel costs (for appointed members $\$ 2,000$ pa and the chair $\$ 5,000 \mathrm{pa}$ ) that some found to be inadequate, with one member reporting travelling $7,000 \mathrm{~km}$ in the period leading to the public release of the ZIP (Duncan 20 February 2012). The HWZC was also working within a context in which further resourcing was constrained by the global financial crisis, and the series of earthquakes in Canterbury which placed significant pressure on regional resources and exacted a hefty personal toll on people. One member stated that he didn't think 'the Zone Committee in its current capacity could have done any more, to be honest, for public consultation' (Max 22 February 2012).

Contextualised within these constraints, the HWZC was reluctant to question policing processes that were occurring at the 'less visible' scales of the household and social sphere (Elmhirst, 2011, p. 131). When asked if the Committee could have done more to try and challenge policing that was occurring through interpersonal relationships, the ECan commissioner on the HWZC stated:

At one of the community meetings, something similar sort of came up where there were one or two individuals out of the community, they all knew one another really well and you could tell. But they were quite, there was more division between them than there was sort of between us on the Zone Committee. But I think (pauses) I don't think it's our job to sort those things out (George 14 February 2012).

George's statement points to some of the paradoxical dimensions of being part of a decision making body that claims to be democratic, but is instructed not to act in a 
representative manner. Inclusive democracy, as described in Chapter 4, requires fair representation and an engaged public. The representative must be connected to their constituents, take account of their interests, reflect their priorities, and understand and communicate peoples' social realities, particularly those whose voices are typically excluded from decision making processes (Young, 2002). The HWZC members were not required to understand or represent the social realities of people who lived in the catchment area, or who were connected to the Hurunui River in some way, including the realities of those who experienced policing and disciplining.

When pressed to elaborate on the quote above, George said that he had been at a meeting during which Julia had mentioned the feelings of intimidation within the District:

I think she might have made some comments about she knew of wives of some of the farmers who were there who didn't share the views of the farmers and things like that. And I think the Committee sort of said, "Well, this is not our debate. If any individual wants to come and express an opinion, we'll do it." And as I say, I would have thought that if anyone wanted to do it privately, they would have been able to do it as well. I don't know how you deal with that really (George 14 February 2012).

Here the commissioner articulates a troubling expectation of a homogenous community in which power relations within households are off limits and in the "private" sphere. Where dissent does exist, it is dismissed as irrelevant to the Committee's work. He also articulates a worrying understanding of how power hierarchies affect political practices. Mouffe (2000, pp. 99-100) states that 'political practice cannot be envisaged as simply representing the interests of preconstituted identities, but as constituting those identities themselves in a precarious and always vulnerable terrain'. Therefore the HWZC contributed to making community identities and meaning (Liepins, 2000a); their unreflexive approach to community left difference and dissent unaddressed, despite an awareness of the policing and disciplining that was occurring. In their review of community based natural resource management, Dressler et al. $(2010$, p. 12) state that despite initial hopes that devolution would lead to local solutions based on local knowledge, processes tend to have 'less to do with the hope of engaging the complex issues of social inequity and sustainability than with measurable, transferable and repeatable outcomes often divorced from local people's reality'. While the HWZC was 
engaged with many peoples' realities in the District, the constraints placed on the Committee (to reach consensus in a short time, to not be representative and recommend a particular outcome) were not conducive to an open, reflexive engagement with the experiences of people subject to disciplining practices. The uneven relations of power enacted and reinforced through conceptualisations of community were poorly understood and addressed by the Committee.

The embedding of particular community meanings and identities within political spaces was particularly pernicious when combined with post-politicising processes of consensus building. Post-politics works to disavow dissent, and consensus based management is deployed as a means through which 'spaces of conflict and antagonism are smoothed over and displaced' (Swyngedouw, 2010a, p. 227). Within devolved environmental decision making, it is this "smoothing over" quality of communities that is viewed so hopefully, and as demonstrated in the quotes above, was present in how the HWZC dealt with conflict. Dissent was dismissed as a personal issue occurring in households, and therefore did not belong in the sphere of water management. Communities, understood as unified by common values, are promoted as a scale through which to avoid politics and divisive contestation and provide technical solutions to quantifiable problems (Clark \& Slocombe, 2011; Dressler et al., 2010; McCarthy, 2005), the very features that radical democratic theorists warn against (Mouffe, 2005; Swyngedouw, 2011a).

As efforts are made to curtail democratic spaces of dissent, debate and creation, Swyngedouw (2011b) describes how violence becomes one of the few ways to express discontent. Worryingly, as the HWZC sought consensus, and divergent nature/society discourses were policed, threats of violence emerged. Two research participants, one in support of a dam on the Hurunui mainstem and the other against water storage, reported receiving death threats. These threats of violence are also indicative of the way in which the we/they relationship had become antagonistic in the face of perceived threats to the continued survival of the community (Mouffe, 2005). Žižek (1999b) and Mouffe (2000) argue that, in protecting the current order, the identification of an enemy to be destroyed is part of consensus discourses. As one Zone Committee member stated:

People are prepared to do damage to people like [local activist] and the kayakers and I think if we don't get the water, the irrigation, and we get a couple of years of drought, those people won't be very welcome around here. 
Amanda: Why is that?

Interviewee: Well the local people think outside people are having too much influence I suppose. ${ }^{27}$

This precarious relationship between those inside and outside of community highlights the personal, embodied dangers of post-politicising practices that work to close space in which people can challenge neoliberal TINA (there is no alternative) discourses. Left without democratic space in which they can be heard as legitimate, and facing people who were deeply invested in a belief in TINA, antagonistic relationships manifested and were damaging for people's wellbeing, contrary to the aims of the CWMS.

\subsection{Successful community based decision making?}

This analysis is not intended to essentialise communities as an inappropriate scale for decision making, or to call for a return to central planning (Agrawal \& Gibson, 1999). As detailed in Chapter 4 there are numerous potential and real benefits garnered from devolved democracy, including learning and sharing. All Zone Committee members interviewed could readily identify successful outcomes and/or aspects of the process. One stated that the 'whole thing's worked better than you could ever expect it to' (Hamish 16 February 2012). A recurring theme was the way benefits were accrued by HWZC members in terms of their personal skills and relationships on the Committee itself. Despite initial pessimism, a high degree of trust was fostered amongst Committee members (Tim 14 February 2012; Brian 16 February 2012; Shona 18 March 2012). For instance, at the Committee's first public meeting one member questioned whether the Committee had any relevance at all, wondering if there was a purpose to their work (Field notes 26 July 2010). By 2012 he thought collaboration and consensus had worked successfully, drawing the Committee members together to make concessions and resolve the issues at hand (Brian 16 February 2012). Furthermore, the emphasis on 'local people doing planning for local stuff' (Chris 23 February 2012) developed the leadership skills of Committee

\footnotetext{
${ }^{27}$ Because this quote deals with issues of interpersonal violence I have taken additional measures to protect the identity of this participant. I have chosen not to use their code name so that they cannot be linked to earlier quotes that may make them identifiable.
} 
members. This was made evident as one member started a catchment group that focused on nutrient use and loss, and irrigation (Duncan 20 February 2012).

Some Committee members thought that the benefits of devolved decision making had extended beyond the skills and trust built amongst Committee members. Shona (18 March 2012) argued that as a result of the HWZC a broader sense of responsibility had developed in the area. She stated that 'people are showing a willingness that they want to do things or they want to be involved or they want to take ownership of the issues and try and find solutions'. For one of the rūnanga representatives the biggest success of the Committee was:

that the community's willing to take responsibility for good management of natural resources, that's probably the biggest plus. You know for forever we've been saying it's somebody else's job - it's either the councils or the government, when really it's our job to look after those resources. So that's probably the biggest plus. People, becoming aware and accepting their responsibilities (Joyce 15 February 2012).

However, as described above, "community" based decision making, while holding the potential for improved environmental governance, does not equate to improved access to democracy for all members of society (Haughton et al., 2013). Panelli (2003, p. 91) has argued for planners to undertake 'explicit reflection on the specific culturally constructed meanings and goals that lie behind a rural vision' and explore how power relations structure access to planning processes. Walker and Hurley (2004) state that considering terrains of power should be at the heart of designing and implementing good collaborative processes. Questions must be asked about how communities are enacted, and discourses and behavioural norms articulated, through environmental governance. In particular, this is a need to engage with the ways people are marginalised at multiple scales, and cultivate greater empowerment across forms of difference to access the environment and decision making processes. What is apparent through this case study is that democratic processes need to approach difference and dissent in a safer way than most participatory processes currently do (Haughton et al., 2013; Peterson et al., 2005).

Addressing uneven power relations within environmental decision making requires the creation of political spaces aligned with more democratic values in which respectful 
relations between adversaries might be developed (Mouffe, 2000). Cairns et al.

(forthcoming) argue that planning practitioners need to reject the goal of consensus, and its impossible promise of win-win outcomes, in favour of approaches that make apparent what is being traded off. Furthermore, they contend that a transparent negotiation of differences may cultivate greater understanding of multiple existing worldviews. Indeed, this approach of identifying "gifts and gains", what is being conceded and what is being attained, has been applied in environmental management processes in Aotearoa New Zealand, notably in the development of a coastal management strategy in Kaikōura, North Canterbury. The strategy was developed by Te Korowai o Te Tai o Marokura, a group consisting of rūnanga members, Te Rūnanga o Ngāi Tahu, recreational fishers, the tourism and commercial fishing industries, environmental interests, and supported by a range of authorities (Te Korowai o Te Tai o Marokura (Kaikōura Coastal Marine Guardians), 2008). Te Rūnanga o Kaikōura's representative to the HWZC was also involved in the Te Korowai process, and stated that it was a 'safer' way to make decisions than the HWZC as it took place over a longer period of time (six years, compared to one year for ZIP development) and made clear to everyone where the benefits and costs lay in a way that the HWZC didn't (Joyce 18 April 2011). The Ngāi Tahu adviser to the HWZC was disappointed that attempts to introduce gifting and gaining to the Zone Committee had failed because of time pressures. He viewed "gift and gain" based processes as making apparent previous concessions that had been made:

I think what you need to be able to do is to recognise where everyone begins the journey of collaboration, in terms of what they've already gained or gifted in the past, and start your collaboration along those lines so that when it comes time to actively gift during that process of collaboration that it's put into context ....having the opportunity to share those things ... that's really important in keeping people together and feeling healthy and positive about working together (Mikaere 21 February 2012).

Such an approach creates space to acknowledge the ongoing legacy of (post)colonial power relations. In Kaikōura, being explicit about who was gifting and who was gaining led to strategy that carefully situates and asserts customary knowledge and practices of the rūnanga within a Eurocentric legislative framework (Te Korowai o Te Tai o Marokura (Kaikōura Coastal Marine Guardians), 2012). In contrast, and in spite of the trust that was 
built between Committee members, one member in particular felt that the concessions made by the environment for economic development weren't adequately communicated and understood, stating 'I think one thing that is out there is the perception from the rest of the Zone Committee that the environment has given up nothing in this process' (Max 22 February 2012).

While an in depth comparative analysis of CWMS processes and Te Korowai is beyond the scope of this thesis, the approach to environmental management in Kaikōura suggests an interesting alternative to consensus based decision making. Discussion that makes differences apparent, allows time to talk about these differences, and unsettles claims to unified and homogenous communities, may indicate a way to navigate uneven power relations as all parties have to make concessions, challenging the status quo and the inertia that is often the result of consensus building (Peterson et al., 2005). Such open engagement that is equipped to identify power hierarchies may cultivate more democratic relations between adversaries that recognise, and accept the legitimacy of the plurality of environmental imaginaries (Cairns et al., forthcoming; Mouffe, 2000). This is to say nothing of more radical alternatives to environmental decision making, or processes initiated from Indigenous worldviews that might begin from an outright rejection of hegemonic constructions of nature (for example, see Miraftab, 2009).

\subsection{Post-politicising communities and the environment - critical approaches}

Previous chapters have sought to describe post-politicising processes that occurred at national, regional and catchment committee scales, as well as how they were resisted and troubled. This chapter has extended this analysis through an examination, situated in feminist political ecology, of the everyday practices of policing that are central to the manufacturing of consensus. People sought to restrict debate in pursuit of a vision for an economically vibrant community that provided more opportunities for residents, secured through "more water" led economic growth. Post-politicising processes were articulated through neoliberal and rural discourses that informed community meaning and belonging. Internal contestations of instrumentalist constructions of nature were disciplined through behavioural norms associated with gender, and through social and economic life. These lived experiences highlight the uneven experiences of power, and hegemonic 
constructions of societal norms, that shape access to the environment (Loftus \& Lumsden, 2008). The effect of limitations on public debate and dissent about the future of the Hurunui River were also evidenced by threats of violence. As the expression of difference was disciplined, understandings of the "other" were increasingly structured along friend/enemy lines. However, efforts continued to be made to resist these processes and pry open space to contest the "more water" imaginary, in spite of social isolation, threats of economic destruction and violence. It is in shifting explorations of post-politicisations beyond the nation state that the multiple existing and possible forms of contestation and politicisation can be highlighted.

The varied experiences of community, oscillating between those that were inclusionary and exclusionary, highlight the need for applied critical approaches to communities that reject assumptions of close-knit relations and homogenous value sets, assumptions that are particularly apparent in notions of rural community (Panelli et al., 2004) and in this case study. Brosius et al. (1998) argue that while many community scholars have developed nuanced and complex understandings of the concept of community, there is a disconnect with planners who continue to make assumptions about common interests and improved democracy through community decision making. This gap between scholarship and practice was apparent in the Hurunui District where the HWZC, facing material and time constraints, didn't question how differing experiences of community were shaping water use debates. Useful to addressing this gap are Nancian conceptualisations of community that highlight its relational nature, the constant negotiation of uniqueness and difference, difference that can only be understood by being with others (Bond, 2011a; Mouffe, 2005). Recognising the nature of these relational performances of community, which vary considerably across time and space, opens opportunities to explore how difference and dissent are negotiated, and uneven relations of power. This understanding of community enables a reframing of antagonistic relationships that narrow access to politics, and may therefore enable the cultivation of more inclusive democratic processes. 


\section{Reimagining environmental futures - relational ethics, Ngāi Tahu and the HWZC}

\subsection{Introduction}

A central task of nature/society theorists has been to challenge the dominance of binaried, hierarchical discourses and instead open space for plurality and difference within democratic processes. In addition to critical examinations of existing ways of understanding nature, particularly those informed by neoliberalised instrumentalism, nature/society studies have sought to be generative of alternative modes of life (Robbins, 2012; Swyngedouw, 2011a). Attempts to (re)imagine and enact non-instrumentalist human/nonhuman relationships have been aided by the broad bodies of literature working within this project. In particular, both Indigenous and more than human geographies have focused on alternative ways of being that emerge out of relational ethics. Relational understandings of ethics involve seeking answers to ethical questions through situated engagement with those around us, and exploring how we might live together (Austin, 2008). In the case of Indigenous and more than human geographies, considerations of living together are inclusive of the biophysical or nonhuman world. However, more than human geographies have been predominantly developed in Anglo/European contexts (Panelli, 2008; Sundberg, 2013), and have largely remained uncertain about how to enact relational ethics with nonhumans. Indigenous geographies, in contrast, have demonstrated already existing ethical formations. The challenge for these geographers working with Indigenous communities in (post)colonial settings has been how to change the colonial relationships that have, and continue to attempt to, erase Indigenous cosmologies and ethical formations based on relationships. 
This chapter draws both more than human and Indigenous literatures into conversation in order to illuminate opportunities for, and challenges to, democratic processes that create space for multiple understandings of nature to exist, and particularly those understandings situated within relational ethics. Where literature from Indigenous perspectives highlights the complexity of already existing worldviews, more than human frameworks provide a language and framework for non-Indigenous people to enact relational ethics without appropriating the concepts of other people in colonising ways (Sundberg, 2013). Together, they form a political ethical project where relational ethics are brought to the fore, and that work to shape inclusive democratic spaces.

Beginning by briefly reviewing both bodies of literature, I explore the complementary nature of more than human and Indigenous geographies and cosmologies through a discussion of Ngāi Tahu's understandings of the Hurunui River. Ngāi Tahu, the main iwi in the South Island, have increasingly asserted their role in environmental decision making, and advocated for their particular understandings of nature. Yet the tribe is also engaged in tricky internal negotiations as they seek economic growth, and in turn, cultural development. As they negotiated these internal complexities, Ngāi Tahu also attempted to reorient the HWZC in a number of ways, and challenge the dominance of compartmentalised, instrumentalist approaches to the Hurunui River. Their ability to shape Committee processes and outcomes contrasted sharply with that of non-Māori who enacted relational ethics for the river. I explore why legitimacy was experienced differently, particularly given recent racist debates over environmental representation in the Hurunui District. To do so, I draw on anti-colonial geographies and (post)colonial planning theory to argue that creating space for relational ethics requires a situated, process oriented approach to decision making. Such situated decision making needs to begin from a recognition of Indigenous rights and work to limit opportunities for Indigenous people to be subjected to colonial discourses that render landscapes empty, and Indigenous voices inauthentic (Porter, 2006, 2010; Prout \& Howitt, 2009). It is also an approach that resonates with Mouffe's $(2000,2005)$ vision of democracy that requires reciprocity and respectful disagreement, and thereby enables ontological pluralism (Howitt \& Suchet-Pearson, 2006). 


\subsection{More than human geographies}

Studies of nature/society relations have typically sought to critique dominant understandings of the world and illuminate the power relations that sustain this dominance, while also imagining new ways of being or empowering alternatives that already exist (Robbins, 2012). One approach to progressing alternative nature/society discourses that has increasingly been drawn into political ecology frameworks is more than human geography.

More than human geographies emerged through science and technology studies, and specifically actor network theory (ANT), and have raised questions about how nonhuman natures act to both obstruct and facilitate environmental politics and processes, for example, of enclosure and commodification (Bakker, 2005). This approach, emerging particularly from the ideas of Latour and Haraway, focuses on the ways the world is coproduced by both humans and nonhumans, and particularly on the 'generative capacities of the non-human' (Bakker \& Bridge, 2006, p. 6). Rather than environmental determinism, these geographers have worked within a relational ontology that posits that everything is 'constantly in-the-making' (Ginn, 2008, p. 336); both humans and nonhumans are mutually constituted, emerging through complex intra-actions, or assemblages (Barad, 2003; Law \& Mol, 2008).

In arguing that nonhumans and humans are mutually constituted, the nonhuman is situated as an actor, an entity that makes a difference thus displaying agency (Law \& Mol, 2008). All actors are 'imbued with the capacity for affect - the capacity to be acted upon, and the capacity to act' (Braun, 2004, p. 1354). More than human geographers reject dominant western understandings of agency as something possessed only by humans, and held at an individual level. Rather, we should think of it as temporarily resting, and emerging through interactions with other things. It's 'the relations ... that are important. Relations which perform. Perform agency' (Callon \& Law, 1995, p. 485). Furthermore, human agency emerges out of a range of "things" ${ }^{28}$ coming together (Bennett, 2010). Whatmore (1999, p. 26) argues that agency should be viewed as 'a relational

\footnotetext{
${ }^{28}$ Bennett (2004; 2010) distinguishes between "animate things" and "passive objects." In writing about things, rather than objects, she attempts to illuminate 'the curious ability of inanimate things to animate, to act, to produce effects dramatic and subtle' (Bennett, 2004, p. 351).
} 
achievement, involving the creative process of organic beings, technological devices and discursive codes'. A more than human interpretation rejects versions of agency based on intentionality, will and reason. An understanding of agency as resting on intentionality and/or morality excludes an array of human (unconscious reactions for example) and nonhuman actions that contribute to networks and produce affect.

This relational approach to agency has been critiqued for not paying adequate attention to the way power concentrates unevenly (Cloke \& Perkins, 2005; Jones, 2009). In practice, the ability to produce affects is highly uneven and is subject to conditions that see power accumulate and condense unevenly (Bakker \& Bridge, 2006; Castree, 2002). Furthermore, Robbins (2012) cautions against tracing banal more than human interactions and reminds us to constantly ask why considerations of nonhuman agency are important.

For more than human geographers, the political purpose and importance of the framework has often centred around its oppositional stance to western, anthropocentric nature/society binaries. Through highlighting the complexity of life they have confronted the separation of nature and society into opposing poles in western knowledge, arguing that this is a false ontology that conceals a world defined by interdependence (Callon, 1986; Haraway, 1985; Latour, 1993). Given the dominance of this "false ontology" within many contexts, recent more than human geographies have turned to attempts to articulate ethical ways of living with more than humans.

Current debates about ethics, like constructions of agency more broadly, are typically based on the 'figure of the autonomous individual [who] represents a cipher of abstract reason/will which inscribes the binaries of mind/body, self/other on to the very possibility of ethical agency in modern society' (Whatmore, 2002, pp. 150-151). More than human geographers have attempted to disrupt the autonomous individual as the repository of ethics, typically framed as human rights. The individual can't be autonomous, they argue, by virtue of its embeddedness within hybrid networks. Because we are knotted together with and constituted through nonhumans, we need to find more respectful ways of being together and consider what an ethic of respect for the nonhuman might look like (Haraway, 2008). Whatmore (2002) argues that the act of describing and understanding the relations that produce humans and nonhumans is itself productive of ethics of respect. However, Haraway (2008) challenges us to go further and move towards an ethic of politeness. Doing so necessitates going beyond normative ethics, which attempt to 
determine what is right or wrong based on the rational human being. Instead, we need to build relational ethics that emerge out of experiences with our more than human kin and a desire to live empathetically (Haraway, 2008; Popke, 2006). Ethical ways of being, therefore, emerge out of specific relationships with nonhuman others.

The implication of relational ethics is that the nonhuman world can no longer be viewed as consisting of discrete objects, or killable entities (Potts \& Haraway, 2010). Rather in killing something, we face our own entanglements with a thing that has shaped us, and are forced into a more intimate engagement with that thing. Haraway (2008, p. 278) argues that:

We "hail" them into our constructs of nature and culture, with major consequences of life and death, health and illness, longevity and extinction. We also live with each other in the flesh in ways not exhausted by our ideologies.

And yet, how the political ethical project of these more than human geographers might be enacted has remained largely unclear.

\subsection{Indigenous more than humanisms}

While the search for relational ethics is important and generative for political ecologies seeking to reimagine environmental futures, Indigenous geographers have focused on the ways that colonial relationships have worked and continue to work to exclude already existing relational ethics. Panelli (2008) argues that more than human theorists have offered limited accounts of these existing ethical relationships because much of the theory is generated in Anglo/European institutions and developed through Anglo/European case studies. Sundberg (2013) also describes discomfort with this Euro/Anglocentric focus, arguing that non Eurocentric ways of knowing are persistently subordinated and ignored in more than human geographies. Such Euro/Anglocentricism is reflective of persistent hegemonies in constructing geographic knowledge, and specifically the forms of colonialism that exist through research and academia (Johnson et al., 2007; Smith, 1999). Panelli $(2008$, p. 807) states that research beyond these Northern settings has already highlighted 'complex intersections between what might previously have been considered the separate environmental, social, economic, political, cultural and legal geographies of an issue or place'. 
Indigenous geographies have generated a substantial body of literature describing how Indigenous knowledges challenge Enlightenment nature/society binaries, particularly knowledges from North America (Johnson \& Murton, 2007; Watson \& Huntington, 2008), Australia (Gibbs, 2009, 2010; Muir et al., 2010; Rose, 2005; Yunupingu \& Muller, 2009) and Aotearoa New Zealand (Ginn, 2008; Roberts et al., 1995; Tipa, 2009). For instance, Rose (2005) conducted extensive research with groups of Aboriginal people in Australia and observed that the people with whom she engaged valued nonhumans as having agency and intelligence, rather than these being qualities solely ascribed to humans. Similarly, Gibbs (2009) recounts how in Aboriginal knowledges there are complex and dynamic weavings of responsibility and reciprocity between humans, nonhumans, spirits and Dreamings. These understandings of agency, responsibility and reciprocity with more than humans illustrates the 'complementary contributions that can be made when scholars move beyond an exclusive focus on Euro/Anglocentric fascinations with posthuman debates and consider how co-productions of geography might engage Indigenous knowledges and cosmologies' (Panelli, 2010, p. 80).

The task for Indigenous geographers and communities, therefore, is not imagining "new" ethical formations, but challenging power inequalities (both in everyday life and academia) and imagining how a plurality of worldviews might respectfully coexist. In particular this has taken the form of contesting the dominance of Eurocentric nature/society binaries in environmental decision making, dominance that sustains colonialisms and closes possibilities to explore multiple ways of being with the biophysical world (Howitt \& Suchet-Pearson, 2006). In Aotearoa New Zealand, key environmental legislation has been critiqued for privileging Eurocentric worldviews. While the Resource Management Act 1991 did recognise the unique relationship between Māori and the environment, and established important benchmarks for good planning practice (Tipa \& Nelson, 2008), ${ }^{29}$ the legislation is still firmly situated within a regulatory and legal context that maintains the dominance of Eurocentric worldviews (Cocklin \& Blunden, 1998). In her

\footnotetext{
${ }^{29}$ Specifically, Part 2 of the Act requires planning processes to consider tikanga (customary values and practices) and the needs of tangata whenua. Further, sections 66 and 74 require territorial authorities to take into account iwi management plans (IMPs). Hutchings (2006) argues that IMPs are an increasingly important environmental management tool for Māori, as iwi can formalise a Māori centred way of being with the biophysical world.
} 
analysis of the RMA, Hutchings (2006, p. 95) states that 'all of the assessments and decisions continue to uphold the assumed power basis of the colonial hegemony as the dominant worldview and system for managing the environment in Aotearoa'. Furthermore in applying the legislation, Hutchings (2006) and Cocklin and Blunden (1998) argue that there are significant structural barriers for Māori participating in environmental decision making. Specifically, local bodies have faced ongoing issues about how to engage and resource iwi. Failing to challenge Eurocentric assumptions about nature/society relationships that underpin decision making practices and structural barriers to access reinscribes colonial power relations on those who understand the world differently (Howitt \& Suchet-Pearson, 2006).

Challenging these assumptions is an important part of broader decolonising projects in (post)colonial settings. Porter (2006, p. 383) states that to 'be (post)colonial, is to be both within and beyond those structures and relationships, the parentheses signifying the continuing presence of colonial processes and their ongoing material effects, despite the voices of the colonised becoming an ever more unsettling challenge'. For Bawaka Country et al. (2013) decolonising work goes hand in hand with broadening understandings of and developing commitments to the co-constituted nature of the world.

Through the case study below, I argue that the worldviews of Ngāi Tahu, ${ }^{30}$ as represented by two rūnanga, unsettled dominant environmental understandings in the Hurunui District. Throughout the following account of Ngāi Tahu's understandings of the Hurunui River, I am conscious that while Indigenous worldviews describe particular ways of making sense of the world, Indigenous people should not be essentialised as occupying a natural position as environmentalists. Representing Indigenous groups in this way risks fixing people in time, as well as reinforcing binaries that have constructed an Indigenous "other" who belongs within nature rather than society (Johnson \& Murton, 2007). Studies of Indigenous worldviews and Indigenous communities have argued that cosmologies are far from homogenous or static; rather interactions change and evolve, and this change is enabled by relational understandings of the world (O'Regan et al., 2006). There is no romantic local or an imagined or static history to which we should return to develop

\footnotetext{
${ }^{30}$ Throughout I refer to Ngāi Tahu and iwi worldviews in order to acknowledge that iwi have distinct ways of knowing - there's no singular Māori perspective although there are many commonalities that have led other authors to describe Māori worldviews (Roberts et al., 1995).
} 
ethical relationships (Howitt \& Suchet-Pearson, 2006). The complexity and dynamism of Ngāi Tahu worldviews will be woven through an account of understandings of the Hurunui River, and iwi worldviews more generally. In addition I explore how ethical relationships with the river were negotiated within a corporatised tribal structure.

Just as there is no Indigenous "other", there is no clear western/Indigenous dichotomy whereby worldviews occupy separate spaces (Watson \& Huntington, 2008). Knowledges about nature represent place and time specific assemblages that may draw on both western and Indigenous sciences to varying degrees. Despite acknowledging that there is no western/Indigenous dichotomy, throughout this chapter I do differentiate between Indigenous and non-Indigenous in order to reflect that Indigeneity is a 'lived reality' (Panelli et al., 2009, p. 361). This lived reality continues to be shaped by colonial power relations; as argued above, non-Indigenous knowledges dominate environmental decision making. Identifying Indigenous realities and knowledges is therefore an attempt to highlight and address these uneven power relations (Palmer, 2006).

This chapter will explore how Māori were able to articulate a relational ethics for the Hurunui River on the HWZC, and suggest how more democratic spaces can be created in order to cultivate broader ontological pluralism (Howitt \& Suchet-Pearson, 2006), the simultaneous and respectful existence of multiple ways of knowing nature, and the various ethical formations that develop out of place based relationships.

\subsection{Ngāi Tahu and environmental decision making - everything is related}

Māori have increasingly asserted deep, complex, and dynamic connections with the biophysical world in contemporary contexts (Panelli \& Tipa, 2007). Māori ontologies are underpinned by certain key concepts, such as whakapapa, the genealogical ties between all things - people, the environment and the spiritual world, including ancestors - ties that contrast with Eurocentric binaried, hierarchical understandings. As one research participant stated:

From my understanding, a western style perspective of the world is man rules pretty much everything he comes across and traditionally has separated everything off. So in terms of managing water, or a river, there's been a 
compartmentalised view taken that doesn't acknowledge that one part affects another, that what you do upstream does have effects downstream. Things have been viewed very narrowly.

Whereas in a traditional Māori perspective, or worldview, very clearly everything is related. What happens upstream affects downstream. In the way that our culture has expressed that, we've used genealogies, what we call whakapapa, which link us to the landscape. It's a way of expressing the worldview ... and our whakapapa actually says that people descend, in terms of the family tree, from the world so that original ancestors are the personification of our worlds (Mikaere 22 July 2011).

According to Tipa (2009, p. 99), 'Māori see themselves as being part of the environment' linked together in kinship (Haraway, 2008). All beings are descendants from Papatūānuku (Earth Mother), Ranginui (Sky Father), and their children, all of whom are gods. These gods dwell in the animate as well as inanimate and therefore these things possess mana, described by Te Rūnanga o Kaikōura (2007, p. 319) as 'respect, dignity, influence'. Understanding that influence rests with both the animate and inanimate resonates with more than human geography literature that posits agency as a relational achievement that occurs through a range of things (Bennett, 2010). The importance of things coming together is illustrated by understandings of the Hurunui River's health:

How I see the life force presently, as it stands now? Struggling. She's under huge stress; poor old girl is being choked with about three or four species of willow that are sucking the life force out of her, draining her dry. She's no longer able to braid in areas, she's being poisoned by over land use on its river sides with e coli and nitrates. She's having the life force sucked out of her during a time when she's in ... stress anyway, in the summer months, when the irrigators are punching out. She has to flood and roll down the freshes during the winter months just to clean herself from what's been going on. The fish species and the manu (bird) species, the bird life that are dependent on her, are struggling because she's not well. She's not dead, she's struggling and she can very easily be given her health back, very, very easily, with good management. She's struggling too at her mouth ... which is her last spot of cleansing before she sees Tangaroa (God of the Sea), she struggles there as well. Again, no sign of manu, kingfisher, kāhu, things of that nature that 
are normally present around those areas. The pukeko's gone from the wetland areas, the lagoons are drying up, she hasn't got the water coming down in times when she needs it (Rob 16 August 2010).

Here the participant describes a lively environment, a "meshwork" of things (Ingold, 2010). The life force of the river exists within a complex knot of other things, constantly moving, 'a relational achievement, involving the creative process of organic beings, technological devices and discursive codes' (Whatmore, 1999, p. 26). However, power accumulates unevenly throughout this net of things - human actions have both affected the rivers vitality, and are important to restoring the health of the Hurunui River through 'good management'. Improving river health requires monitoring and assessment against established indicators, epistemological approaches shared with western science. However, Ngāi Tahu's indicators are unique, and speak to significant silences in western scientific regimes, particularly the co-constituted nature of river environments (Tipa, 2009).

For Ngāi Tahu, the river enables and is part of the spiritual world. This world consists not only of gods such as Tangaroa, but also wairua, spirit that many understand as resting in inanimate as well as animate things. Mauri binds together the spiritual and physical world and is the life giving and sustaining force that is possessed by all parts of the environment. Many Indigenous peoples 'regard the earth and nature with spiritual attitudes of respect, restraint, humility, awe, care, reciprocity, and love as well as an appreciation of the resources, utility, dangers and beauty' (Stevens, 1998, p. 21). Panelli and Tipa (2007) describe Māori ways of knowing that conceive of ecosystems combining a range of phenomena, rather than simply being the domain of rational science. Further, humans are not held as outside to these ecosystems:

I would describe it as part of my genealogy, [the] Hurunui and all of those basins, catchment areas, tributary streams. I am as much a part of them as they are a part of me. They have provided wealth, sustenance, and a future for all generations before me, so therefore I have a responsibility to be kaitiaki (guardian), and look after it now ... I'm a part of it, physically as well as spiritually and mentally (Rob 16 August 2010).

The rūnanga representatives' understandings of their intimate entanglements with the Hurunui River actively blurs western nature/society hierarchical binaries. Past, present and 
future life is inherently linked to humans' care for the river, and the river's function as part of human health, both physically and spiritually:

The health of the river goes back to what I was taught as a boy from my now tīpuna (ancestors), because the ancestors', your health and the health of your family, and your visitors is reliant on the health of the river that gives the health to the land. So if your river's sick, and your land's sick, then you as a whānau (family) are sick. And if you as a whānau are sick, it extends out that you as a tribe are sick (Rob 16 August 2010).

At the heart of the link between whānau and river health is mahinga kai, the 'food and other resources and the areas they are sourced from' and the health of the resources (Te Rūnanga o Kaikōura, 2007, p. 319; Tipa, 2009). Unlike colonial understandings of conservation as preservationist and excluding humans, customary food and resource gathering is a vital cornerstone of Te Rūnanga o Kaikōura and Te Ngāi Tūāhuriri Rūnanga's environmental management (Waitangi Tribunal, 1991). In the past, the Hurunui River was renowned for its stocks of tuna (eel) and inanga (whitebait) (New Zealand Parliament, 1998). Mahinga kai were managed through complex customs and rules but in many places colonisation and sudden population pressures, accompanied by Pākehā conservation laws and private property rights, disrupted the ability of Ngāi Tahu to access and carefully manage these resources (Waitangi Tribunal, 1991).

However, the river is not a 'mere resource' (Plumwood, 2003) - it is a key site of interaction and an essential part of Māori culture. In order to care for the river, human/nonhuman relationships are governed by tikanga, 'customary values and practices' (Te Rūnanga o Kaikōura, 2007, p. 320) which are based on 'respect and reciprocity' (Roberts et al., 1995, p. 12). The principles of respect and reciprocity are encapsulated by the principle of kaitiakitanga - that as well as rights to use the river in certain ways, we have equal responsibilities to care for this wāhi taonga (treasured place, location). The responsibilities are to 'Papatuanuku and her children and to ensure that cultural values can continue to be enjoyed by future generations of Iwi Māori' (Panelli \& Tipa, 2007, pp. 453-454). Kaitiakitanga explicitly places humans within an ethical relationship of respect and care with the more than human world. 
Kaitiakitanga is about nurturing, caring ... you can be kaitiakitanga in so many different ways. It's all very well to care for something, you've got to go further and nurture. We don't own land, we're part of it and we're only here to nurture it and look after it for our children and their children, your children (Rob 16 August 2010).

Another research participant explained how humans are not dominant within this relationship, stating 'we are just part of the bigger picture, we're not the king of the bigger picture' (Mikaere 22 July 2011).

The genealogical, non-hierarchical links of whakapapa and the emphasis on respect and reciprocity by the representatives from Ngāi Tahu involved in the HWZC illuminate a particular way of enacting relational ethics with the Hurunui River.

\subsubsection{Ngāi Tahu worldviews and a corporatised iwi structure}

However Ngāi Tahu worldviews are not static; the iwi has been innovative in negotiating changing relationships with the environment and within the (post)colonial context of Aotearoa New Zealand (O'Regan et al., 2006). At times this change and innovation has been difficult. Particularly contentious are processes of corporatisation and ambitions for tribal economic growth, particularly as a tool for cultural revitalisation. Shifts to iwi corporatisation and commercialisation are indicative of a new phase of recent state-Māori relations. Following a long campaign for recognition of Māori rights, and revitalisation of Māori culture and politics (known as the Māori Renaissance), iwi were recognised as partners to the state in the $1980 \mathrm{~s}^{31}$ Māori were increasingly represented and embedded within state institutions and structures, and Māori culture was progressively normalised and institutionalised (Larner, 2006). By the 1990s, there was a shift in focus to retribalisation, 'a localized ideology which serves neoliberalism's wider interests and is, in turn, served by neoliberalisms' (Rata, 2011, p. 347). Rata (2011) argues that notions of indigeneity have been used to enclose the commons as iwi have corporatised and benefited from privatisation, while also abandoning class politics in favour of identity politics. As a result disadvantaged (largely urban) Māori who aren't directly affiliated with

\footnotetext{
${ }^{31}$ This recognition came through the Treaty of Waitangi Act 1975, subsequent amendments, and through the decisions of the courts (see also Chapters 1 and 5).
} 
an iwi have been excluded from Treaty settlements (Rata, 2011). Furthermore, Maaka and Fleras (2005) state that formalised iwi structures have been moulded by the Crown to fit with existing (colonial) political, economic and legal systems (also Bargh, 2007). In 1996 Te Rūnanga o Ngāi Tahu became a formalised legal entity through an Act of Parliament. The iwi's long serving Kaiwhakahaere (or chairperson) Tā Mark Solomon (2006) argues that the new corporate model enabled the tribe to distance themselves from paternalistic colonial relationships. The formalised iwi body no longer had to constantly seek approval from the Minister of Māori Affairs for expenditure, and therefore most activities. The iwi could now identify and pursue its own objectives without such direct state involvement.

Te Rūnanga o Ngāi Tahu is made up of 18 papatipu rūnanga (marae based councils that administer the affairs of the hapu, or sub tribe). Each of the rūnanga elects a representative to the tribal council, which represents, supports and acts for Ngāi Tahu Whānui, or members (see Figure 6). The council is in charge of making decisions about governance, distribution, and undertaking advocacy. Rūnanga maintain control over local issues. Ngāi Tahu Holdings Corporation sits alongside the council, coming under the same charitable trust organisation, an organisation of which Te Rūnanga o Ngāi Tahu is the sole trustee (Te Rūnanga o Ngāi Tahu, n.d.).

Ngāi Tahu Holdings generates significant revenue for the iwi; in the financial year to June 2013 the corporation made a net profit of $\$ 95.66$ million and reported managing assets worth $\$ 747.87$ million (Ngāi Tahu Holdings Corporation, 2013). There are a number of subsidiaries, including Ngāi Tahu Property (NTP). NTP stands to be one of the main benefactors of Hurunui water storage as it will facilitate the conversion of the 9,380 ha Balmoral pine forest into dairy farms. Because of this interest, NTP was a major shareholder in the Hurunui Water Project. However, some of the rūnanga were unhappy with HWP's plans, and NTP's support, in particular the prospect of a dramatically altered Hurunui mainstem. Both Te Ngāi Tūāhuriri Rūnanga and Te Rūnanga o Kaikōura, and the broader body of Ngāi Tahu, decided to support an application for a WCO that would have prevented the HWP from damming the South Branch and putting a weir on North Branch. As a result of the conflicting positions between the local rūnanga and the commercial arm of the iwi, NTP drew back from its involvement with HWP and placed its shares in a trust (Hutching, 2009). 


\section{Papatipu Rūnanga}

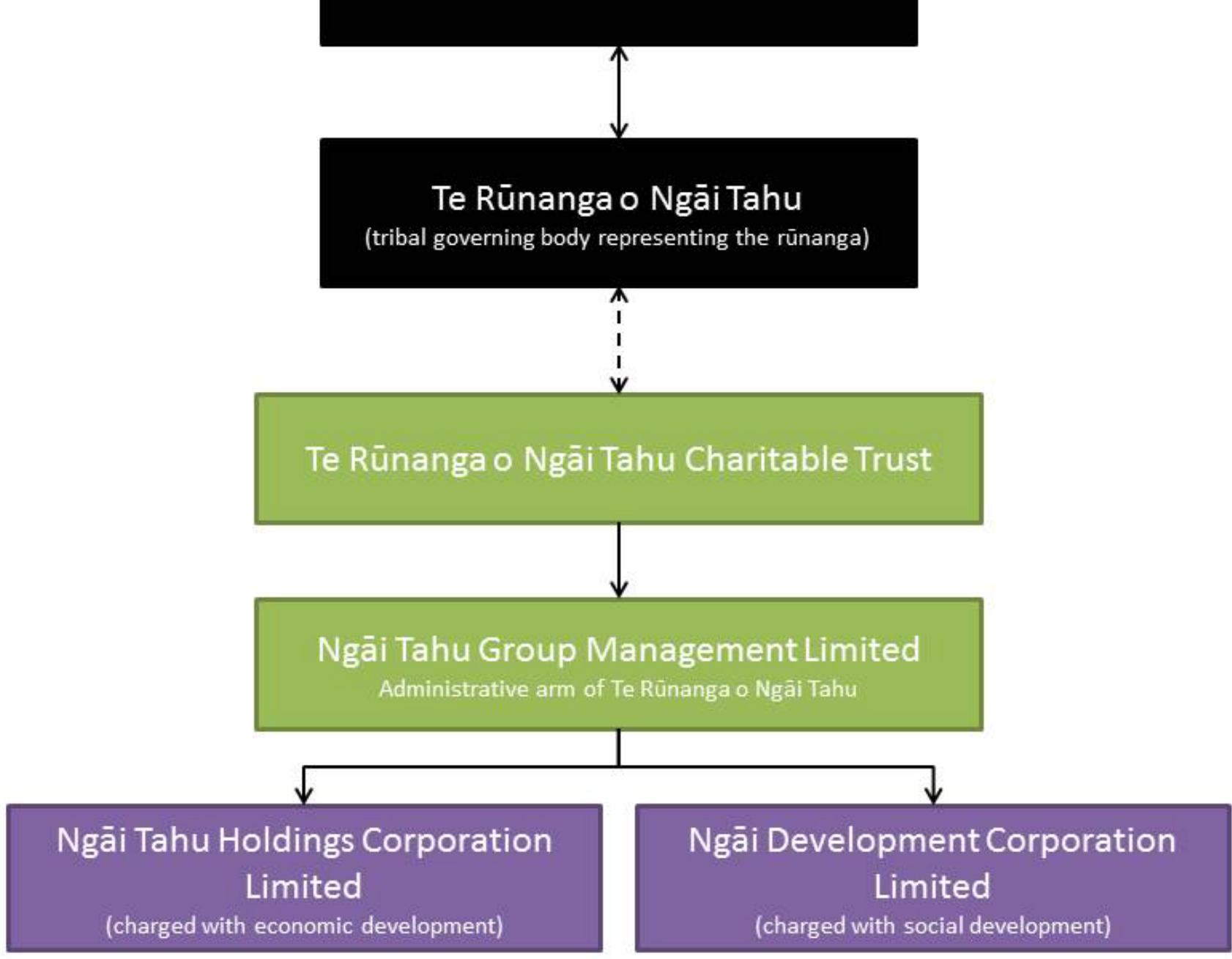

Figure 6 Abridged organisational structure of Ngāi Tahu 1998 (adapted from Cant, 2005).

According to a representative of Ngāi Tahu Property:

we were walking alongside the rūnanga but then the Water Conservation Order put a lot of extra pressure groups into the mix. As a consequence of that the rūnanga decided to change its position and that change in position then put us in conflict with where the rūnanga were going. As a consequence of that we had to pull away from the Hurunui Water Project for a period of time and realign ourselves with the new direction that Ngāi Tahu was taking at that time (James 29 November 2011). 
The iwi structure that created separations between rūnanga and the commercial arm was identified by rūnanga representatives to the HWZC as the result of (post)colonial needs for legal entities, rather than reflecting traditional ways of organising (Field notes 26 July 2010). As a result there was significant work required to reconcile the separate bodies. Joyce (18 April 2011), the representative for Te Rūnanga o Kaikōura, stated that there had been a lot of disagreement between rūnanga and NTP, but it was grounded in a recognition that they needed to work together. In order to form a united position on the Hurunui River, a working cluster was established to generate conversation about the Hurunui across the diversity of the iwi (Moana 22 November 2011). The mana whenua (customary authority) group, consisting of people selected by the two rūnanga and NTP, met every six weeks to discuss water management issues and develop understanding (James 29 November 2011). When the CWMS was rolled out and the new ECan commissioners committed to moving beyond antagonistic and legalistic water politics, ECan asked rūnanga to revoke their support for the WCO application. For Joyce (18 April 2011), Ngāi Tahu had to show a commitment to the collaborative process, particularly as the iwi had been part of developing the CWMS. So, four months into the work of the HWZC, the rūnanga withdrew their backing of the WCO.

Throughout the Zone Committee process, there were moments of tension between Ngāi Tahu Property and rūnanga representatives as these complexities, specific to that time, place and people, became evident. During initial Zone Committee meetings, rūnanga representatives strongly opposed mixing water from the Waiau and Hurunui Rivers through irrigation schemes (Field notes 16 August 2010). One of them, shocked that mixing the rivers' water was still an option before the HWZC, explained to me that 'the mixing of water is for Māori, culturally, and spiritually is a no go area, [and] is expressed greatly in iwi management plans' [pers comm Rob 19 August 2010].

However, three months later as I stood with a group of people after a HWZC meeting James, a representative for NTP, stated that while he was relieved that rūnanga had withdrawn their support for a Water Conservation Order over the Hurunui River (Greenhill, 2010a), he joked that he was ready for the challenge of getting them to relax their opposition to water mixing (Field notes 8 November 2010). It was apparent that James felt that NTP was in a position of power relative to the rūnanga. Indeed, the 
rūnanga representative so vocal in his opposition had recently left the HWZC and the other representatives began to emphasise the potential to mitigate mixing.

Later in the Zone Committee process, as described in Chapter 4, NTP lobbied for increased nutrient allowances in the Hurunui River. At the September 2011 Zone Committee meeting, the representative for Te Rūnanga o Kaikōura was visibly frustrated with the ECan planner who had responded to the lobbying and led calls for increased limits. She said that he should 'know the difference between Ngāi Tahu Property and Ngāi Tahu. You know [James] doesn't represent Ngāi Tahu. You know who you should have consulted with' (Field notes 19 September 2011).

These tensions and negotiations were ongoing, reflecting the challenges that the iwi faces. As Joyce (15 February 2012) stated:

it's the ultimate balance that all Ngāi Tahu have to find. Our tribe wants to make money. We as individual Ngāi Tahu want the tribe to make money. That's their brief. [But] we're just not prepared to sacrifice everything for it. We'd rather be more innovative than that and look at other ways to make money. It's the ultimate balance isn't it, not just in the wider community but internally and not even just internal of Ngāi Tahu, but internal within each rūnanga and in actual fact, internal within each whānau.

One of the whānui (community) members, however, was very unhappy with the concessions that were made on the Zone Committee. Moana has long been involved with the Hurunui River and decision making about it, and he felt that too many concessions had been made to NTP. He was particularly disappointed that Ngāi Tahu had allowed so much mitigation rather than more firmly asserting their worldview. Compared to his expectations of what would be achieved on the HWZC, he didn't think that the tribe had sufficiently enacted relational ethics:

I feel [Ngāi Tahu's contribution] has been not very substantial at all, not a very substantial effect at all on environmental management with the potential methods we have to give value to those resources and to continue our own rightful practice within those worldviews (Moana 22 November 2011). 
He went on to describe how the corporate structure of Ngāi Tahu, as established within the Treaty settlement process, had evolved away from advocating for the people towards emphasising the role of Ngāi Tahu Holdings Corporation, which is not always guided by the tikanga of the iwi. He stated that Te Rūnanga o Ngāi Tahu was:

set up to represent us, to take our commissions to the Crown, not to direct us. .... It came from the people, the people don't come from it. We're not shareholders or stakeholders, we're owners. So while our group was working on being good participants in the consultation process, as a group of Te Rūnanga o Ngāi Tahu we have a group within the rūnanga called Ngāi Tahu Property, development, it's a money making branch of it. The crux of it is when we signed the deed, $\$ 170$ mil to people fighting for their rights ... [Ngāi Tahu Holdings was established to] manage the money and grow the pūtea (fund), and grow it and to do our best to have it always conformed and aligned to our tikanga. However, it's not Ngāi Tahu people or tikanga fronting it. ... I was opposing [Ngāi Tahu's position on water takes] the whole time, I still oppose any water take to this day, privatisation and mismanagement, over-pollution, any more taking for the agriculture sector when there's a survival necessity on the table. ... And Property has only done their job and tried to find investment without having a significant understanding of where we come from. So we need to align them with that, or we need to change the structure (Moana 22 November 2011).

For Moana, the corporate structure of the iwi has resulted in success being measured as economic growth (Hutchings, 2006), and when it came to decision making about the environment, Ngāi Tahu has made too many concessions in the interests of growth. His concerns illustrate the sometimes fraught nature of iwi negotiations about how to enact their worldview while also navigating neoliberalised spaces (Bargh \& Otter, 2009), and how these tensions are exacerbated by the Crown's pressure for iwi structures to fit with colonial ideologies. The debates occurring within the tribe are demonstrative of the flaws of a settlement process that doesn't adequately acknowledge or engage with issues of Māori sovereignty and appropriate constitutional change (Bargh, 2007).

The following section will explore how an Indigenous more than human ethic, negotiated alongside material demands, pressures and neoliberal spaces, was able to take shape and 
affect the political space of the HWZC. In particular, I explore what this means in relation to the ongoing project of decolonising environmental decision making.

\subsection{Contesting nature/society binaries in (post)colonial places}

A relational ethics with the Hurunui River, as enacted by the rūnanga representatives and Ngāi Tahu's advisor to the HWZC, successfully shaped aspects of the Committee process as well as outcomes. When asked how he thought he and representatives for the two rūnanga had affected the Zone Committee the Ngāi Tahu advisor responded:

we've been consistent in, I think, the fundamental messages we've been delivering ... and that, from the very first opportunity that was always about the health of the water. And that's sort of like things that have been handed down, that's old thinking that we get, that you've gotta really ultimately look after the fundamentals and once you've done that everything else falls into place. So I think we've been able to, well I hope we've been able to keep people tuned into that (Mikaere 21 February 2012).

Indeed, iwi representatives repeatedly emphasised the importance of a more reciprocal relationship with the Hurunui River and Ngāi Tahu's rights, interests, uses and cultural values (Field notes 18 April 2011; 30 May 2011; 18 July 2011). Joyce pressed the Committee to consider what could be given back to the river and how the Committee could exercise responsibility to it, given that they were also enabling the abstraction and use of "more water" (Field notes 20 September 2010; 18 April 2011; 14 November 2011). Further, Ngāi Tahu's Ki Uta Ki Tai, mountains to the sea, philosophy eventually shaped the way Pākehā Committee members thought about the catchment. Ki Uta Ki Tai is a framework for drawing together culturally based resource management in a comprehensive and whole way (Tipa \& Nelson, 2008). This was in direct contrast to fragmented approaches to the river that constructed it as a series of objects, rather than a lively thing connected to other lively things (Bennett, 2004).

By insisting on certain "fundamentals", articulated through kaitiakitanga and Ki Uta Ki Tai, the rūnanga members sought to expand the ideas of who and what were part of the "common good" that collaborative processes seek to define and work in the interests of (Young, 1996). The foundations of the Zone Committee's work defined common good in 
part as economic growth through enclosing nature, but as one Pākehā Committee member described, rūnanga representatives:

bring sort of the holistic view of the world. They bring the mountains to the sea. They bring the riparian importance and all of the other bits and pieces that go with that. And maybe some words that capture that that perhaps other members of the Committee hadn't been exposed to in the past. And you know they've probably heard of mahinga kai, kaimoana (seafood), they'd probably heard of some of the other words that we haven't perhaps incorporated so much in the [Zone Implementation] Programme but they'd been increasingly exposed to over the last 18 months. And I've felt really good, in fact about how the Committee members have really grasped some of those notions (Tim 14 February 2012).

This quote highlights the potential for dialogue to bring about transformative social learning that leads to increased understanding of others and respect for difference (Bond \& Thompson-Fawcett, 2007; Porter, 2006). As trust was built between HWZC members (see Chapter 5), conditions became increasingly favourable to enable listening, sharing and learning about different worldviews (Allen et al., 2011). Coombes (2007a), while acknowledging the dangers of privileging community as a location of democracy, states that discourses of community can prove fruitful for re-placing Indigenous people at the heart of environmental management. Where states have been slow to take leadership in encouraging Indigenous ownership of, and empowerment within, environmental decision making (Coombes, 2003) a local scale that incorporates regular face to face interactions can develop cross-cultural understanding, and possibly novel arrangements for management. Furthermore, heightened understanding may lead to improved and more viable outcomes. In their study of a collaborative freshwater management initiative, Allen et al. (2011, p. 528) argue that focusing on social learning processes 'contribute[s] to a shared understanding as a precursor to the development of innovative solutions that can support more enduring catchment management'.

Specific aspects of Committee outcomes particularly reflected the cross-cultural learning that took place. Following the promotion of Ki Uta Ki Tai the HWZC increasingly considered the role of hāpua, or lagoons, and river mouths, where previously debates about the river, and its value, had taken a narrow focus on the upper reaches of the river. According to one Committee member 'we will work more in the measuring nutrient levels in the river 
and the lagoons and at the river mouths, which hasn't been done before and that's something [Joyce] has pushed for' (Hamish 16 February 2012). The Ki Uta Ki Tai philosophy was also linked to ideas about mahinga kai that were increasingly understood and seen to be important, even if understandings were at times reductive of complex concepts. Hamish stated, 'I'll give [Joyce] a bit of credit for that. Yeah, it's the river mouth thing more than anything else ... the lagoons and the food gathering thing' (Hamish 16 February 2012).

In spite of a "more water " rationality that oriented the work of the Zone Committee towards a particular outcome, and (post)colonial critiques of planning that is structured around 'a static, singular view of what is worthwhile, valued and desirable' (Howitt \& Suchet-Pearson, 2006, p. 329), rūnanga were effective in generating shifts within the HWZC. When asked to reflect on whether she thought Te Rūnanga o Kaikōura and Te Ngāi Tūāhuriri Rūnanga had shaped the Committee process, Joyce answered, 'people tell us we have. Certainly the outcomes show we have' (Joyce 15 February 2012). In particular she was proud of playing a part in shifting the preferred location for water storage away from the Hurunui mainstem because of the iwi's special relationship with the river, in terms of their history, whakapapa and ongoing cultural practices (Joyce 15 February 2012; see also Ministry for the Environment, 2009). In turning attention to storing water in the Waitohi Valley, NTP could still access water for land conversion, but key values and sites on the Hurunui would be protected.

For the ECan commissioner on the HWZC, cross-cultural learning came at an important time in which there is wider debate through which Pākehā are interrogating and assessing the way we interact with the biophysical world. His understanding of Māori worldviews was that:

It's very much about that continuity that they're just here and they have the stewardship of the land and they're passing it on to the future. For a lot of Pākehās, it's not something we've ever thought about, you just use the land, it's always going to be there and you don't think about it. So I think there's a transition going on. There is a change where people are beginning, where Pākehās are picking up some of those things that Māori have always felt and always understood (George 14 February 2012). 
Unfortunately, however, the ECan commissioner failed to recognise the limitations experienced by those Pākehā and non-Māori who did already enact a respectful relational ethics with the Hurunui River. In contrast to the legitimacy that Ngāi Tahu were seen to have in talking about the more than human river, Pākehā were typically not able to be heard and understood as rational when describing non-instrumentalist connections (Rancière, 2001). Many participants articulated relational ethics based on reciprocity and respect towards, or kinship relationships with, the river. The practices of policing and disciplining that limited public debate and discussion of these understandings were described in Chapter 5. However, those that managed to contest the boundaries that were created around accessing public debate faced further barriers once they did come before the HWZC. In particular, they felt limited to western science discourses because they were non-Māori. As one research participant stated:

It's like where I was struggling there to say what is my spiritual connection with the Hurunui ... I found it very difficult to put that sort of stuff into words. But they [rūnanga representatives] roll in. They put it in their terms. But it's something that I could whole heartedly agree with, that's sort of a spiritual importance to them that the Hurunui is left unmolested basically. They can say things we can't, we westerners can't. They've got a background which allows them now to stand up in public and say spiritual values, and thank goodness. 'Cause if I get my time in front of the Committee, I've got to maintain strict sort of scientifically backable protocols. It's got to be couched in lists and terms which are justified within scientific boundaries (Louis 31 October 2011).

Similarly, Henry, a kayaker, identified the Hurunui River as a family member during our interview, describing how his kinship relationship with the Hurunui River had politicised him in debates about water use (Henry 1 November 2011). Early in the HWZC process, he gave a presentation to the HWZC that described non-instrumentalist ways of understanding and valuing the river. The Committee's response was to dismiss noninstrumental values and direct Henry to coming up with other damming options (see Chapter 4). Subsequently, despite attending and contributing to most meetings, he appeared to have limited agency to discuss the river in terms of familial attachment in front of the HWZC and be seen to be legitimate and rational (Field notes 31 January 2011; 18 April 2011). 
The following sections will explore how, in contrast to non-Māori, Māori were able to contest the narrowing effects of the "more water" discourse, and legitimately enact relational ethics. To do so, I will examine how iwi experiences within environmental decision making in the Hurunui District were shaped by recognition, or not, of Indigenous rights and (post)colonial power relations.

\subsection{Representation and recognising rights - failure in the Hurunui District}

Coombes $(2013$, p. 84$)$ argues that current Aotearoa New Zealand politics are characterised by an 'increasingly anxious white population', a population that is struggling to come to grips with questions of (post)colonial resource allocation and management. These often fraught politics were clearly illustrated by conflict in the Hurunui District over Māori representation in environmental decision making, conflict that reached its peak seven months prior to the first meeting of the HWZC in mid-2010. The following section will explore this conflict, and why the legitimacy of Ngāi Tahu voices were treated so differently within the District conflict and later by the HWZC.

In 2004 the Hurunui District Council (HDC), Te Rūnanga o Ngāi Tahu, and the two rūnanga ${ }^{32}$ whose takiwā (traditional territory) cover the District, signed a memorandum of understanding (MOU) to give greater effect to the partnership relationship established under Te Tiriti o Waitangi, and affirmed through legislation and Ngāi Tahu's settlement with the Crown. The purpose of the MOU was to develop a 'cooperative and mutually beneficial system of managing the natural, physical and spiritual resources' of the District (Te Rūnanga o Ngāi Tahu et al., 2004). Within the document the council acknowledge Ngāi Tahu's role as tangata whenua and the authority the iwi have traditionally exercised. The MOU also mandated that there would be at least one representative from Ngāi Tahu on the Environmental Services Committee of the District Council, a committee that gathered information and made recommendations to the District Council. However this clause of the MOU wasn't immediately acted upon.

Three years later council contractors were digging new sewer ponds and came across some kō iwi tangata (human remains) (Hurunui District Council, 2009b). When the

\footnotetext{
${ }^{32}$ Te Ngāi Tūāhuriri Rūnanga and Te Rūnanga o Kaikōura
} 
contractors called the council office to ask for advice on what to do with the bones, they were told to kick them to one side. Iwi members heard about the incident, and many people were deeply upset by the council's advice and their failure to act in good faith and contact the iwi. It was recognised by the Mayor of the District at the time, as well as rūnanga, that a more positive relationship needed to be developed and one way to do this was to act on the requirement in the MOU for Ngāi Tahu representation on the Environmental Services Committee (Hurunui District Council, 2009b). However, rather than simply honouring the council's commitment, council members decided to notify a proposal to include iwi and invited public submissions. A total of 195 submissions were received, with 21 in support of Ngāi Tahu representation on the Committee, 14 supporting it in part and 159 opposing it, although it was noted that a number of those opposing misunderstood the proposal. ${ }^{33}$ Many people argued that the proposal was racist, as it would give Māori more rights than Pākehā, and compared it to apartheid. One person's submission was summarised as '[e]veryone has equal rights. Rūnanga have used myths and legends to sway and influence decision making which is inappropriate for this age' (Hurunui District Council, 2009a, p. 15). Furthermore, people questioned whether Ngāi Tahu would have adequate skills to properly participate on the Committee (Hurunui District Council, 2009d). And in clear examples of constructing the absence of Māori, one person claimed that 'there is no permanent Māori population' in the District (Hurunui District Council, 2009a, p. 14), and another stated, 'there are barely any environmental issues affecting Māori' (Hurunui District Council, 2009a, p. 11).

The Hurunui District is predominantly Pākehā, but statements claiming the complete absence of Māori (within boundaries determined according to colonial logics, rather than spatial and temporal boundaries decided by the iwi or rūnanga) discursively erase the existence of Māori from the area. This ordering of space insists that the appearance of Māori is 'inauthentic' as Māori aren't seen to belong, and furthermore their irrational ideas have no place in rational decision making (Prout \& Howitt, 2009, p. 397). These debates culminated in an HDC meeting in November 2009 during which people could

\footnotetext{
${ }^{33}$ Some submitters (it's not clear exactly how many) thought the proposal was for a Ngāi Tahu representative to be appointed to the Hurunui District Council, rather than the Environmental Services Committee of the Council (Hurunui District Council, 2009a). It's not clear from documentation how people came to understand the issue in this way.
} 
speak to their submissions. A representative of Te Rūnanga o Kaikōura, who later became a Hurunui Waiau Zone Committee member, attended the meeting and stated that many submissions, including those from some District councillors were 'pure and utter racism' (Joyce 18 April 2011), and people from the iwi were left feeling angry and upset (Joyce 15 February 2012). Repeating community concerns that democracy would be threatened by special treatment of the iwi, the majority of the council sided with those opposed to honouring the MOU and rūnanga were denied representation.

Much of the planning literature from a Habermasian tradition advocates equal access to and inclusion in decision making processes (Innes \& Booher, 2004). Innes and Booher (2010, pp. 36-37) state that to create 'authentic dialogue' 'deliberations must be inclusive of all major interests and knowledge ... and all must have equal access to all the relevant information and an equal ability to speak and be listened to'. For minorities, Brownlow (2011) contends, principles of equal access may enable the pursuit of political aspirations from within, or insurgency to express resistance and reshape the participatory process itself (also Ghose, 2005). Indeed equality is a key component of theorisations of democracy (Mouffe, 2000; Swyngedouw, 2010b). However, (post)colonial planners and geographers are critical of principles of equality within planning processes. As argued in Chapter 4 , the structural barriers to equal access and equal ability to speak are not adequately addressed in planning theory (Takeda \& Røpke, 2010). Structural barriers to Indigenous participation vary, reflecting particular legal, political and economic contexts. In Aotearoa New Zealand Māori are more likely to be economically deprived than Pākehā, and under-resourced communities may find it more difficult to be able to afford to participate and take on the responsibilities associated with devolution (Cocklin \& Blunden, 1998; Tipa \& Welch, 2006). The idea that neutral terrains of power are possible also ignores structural obstacles, and that historical and contemporary colonial power relations cannot simply be left at the committee door.

Importantly, notions of equal "stakeholder" access and participation can be deeply limiting when it comes to promoting and empowering Indigenous communities; local authorities are often reluctant to acknowledge the role of tangata whenua for fear that environmental or recreational groups will seek similar rights (Tipa \& Welch, 2006). These fears were apparent in the Environmental Services Committee conflict, where requests to honour the MOU were met with claims that democracy was being circumvented and there 
was no reason to privilege Ngāi Tahu representation over any other interest group (Hurunui District Council, 2009c). However, claims to equality ignore uneven (post)colonial power relations. Furthermore, Indigenous interests in the biophysical world are unique, drawing specific histories and cosmologies into the formation of ethical relations. Iwi understandings of the biophysical world are developed in place specific ways and lived by iwi (pers comms Mikaere 15 January 2013), and, as evidenced by the concept of mahinga kai, land and place are at the core of cultural practices. Such cultural practices were violently interrupted by colonialism, a process that involved systematic appropriation of Indigenous lands, and the arbitrary persecution of Indigenous peoples (Hibbard et al., 2008). It is addressing this violence, the widespread and ongoing implications of alienation from land and water and persistent power inequalities, that necessitates an understanding of iwi as more than stakeholders and as occupying a different place to other interest groups.

Moreover, colonialisms manifest in multiple forms, including within preservationist environmental discourses. Environmental groups often imagine nature as landscapes devoid of people, as untouched and pristine wilderness, in effect denying the very existence of Indigenous peoples and their histories (Pickerill, 2008). Mythical notions of wilderness, Cronon (1996) argues, sustain binaried, Eurocentric versions of nature. These discourses are common in Aotearoa New Zealand and were deployed through Forest and Bird's national campaign to 'Save our Wild Rivers', a campaign that included the Hurunui River (Forest and Bird, 2011). Ideas of a "wild" river were also expressed through the HWZC space (Field notes 20 September 2010; 31 January 2011; 18 April 2011). Through such discourses, Indigenous people are written out of natures by those who want unhindered economic development, and by those aiming to prevent it (Willems Braun, 1997). Porter (2006) and Takeda and Røpke (2010) warn that treating all parties as entitled to equal access and participation sees the dominance of non-Indigenous worldviews go unchallenged. Open inclusion, and equality, may actually limit the possibilities for Indigenous worldviews to be articulated and heard where Eurocentric knowledges have been and are dominant.

For some scholars, amplifying Indigenous voices in formal processes challenges ideals of liberal democracy. Rata (2011) states that there is a significant tension between equal democratic rights for the public, and Indigenous claims to special rights. She warns that 
the emphasis on identity politics risks descending into ethno-nationalist politics that sacrifice liberal democracy in the interests of a small elite. Yet the persistent barriers that Māori face within environmental decision making, including structures and institutions that remain firmly based on western ways of being and doing, and overt racism that renders Māori as inauthentic and not belonging, illustrate a pressing need to address the stubborn dominance of Eurocentric knowledges (Coombes, 2007a). Achieving genuine equality in (post)colonial states first requires recognition and empowerment of Indigenous people, recognition that can then begin to take hold in broader society (Howitt \& Lunkapis, 2010; Howitt \& Suchet-Pearson, 2006). Following this recognition, Porter (2006) suggests that rather than equal access planners should think critically about who should be included in and excluded from environmental decision making in order to further shift Indigenous people beyond stakeholder status. She argues that considering inclusions and exclusions can limit instances of (post)colonial oppression, and signals that Indigenous people occupy a unique place in environmental decision making by virtue of ongoing colonial practices and the importance of place to Indigenous cultures (Coombes, 2007a; Sandercock, 2004). In this way, power imbalances can begin to be addressed and conditions created that are more conducive to multiple worldviews existing within and shaping the planning process.

The dangers of universal public inclusivity, veneers of equality and constructions of Ngāi Tahu as one of many "stakeholders" were evidenced during contestation over Ngāi Tahu representation on the Environmental Services Committee. Inviting public submissions created a platform for overt racism, undermined the goals of the MOU and thereby further ostracised Ngāi Tahu from District decision making, and enacted the erasure of Māori from the area (Prout \& Howitt, 2009). However, the conflict also acted as a moment of rupture, where racism was able to be named in a way it couldn't be previously in its hidden form (Rancière, 1998). Following the fall out, the Mayor publicly apologised to the rūnanga for the embarrassing episode and the racist nature of the debate (Joyce 15 February 2012).

\subsubsection{Representation and recognising rights - the CWMS and HWZC}

Into this context of rupture and overt racist politics the CWMS was rolled out in the Hurunui District. In contrast to HDC's reticence in acknowledging the need for Māori 
representation, the Strategy mandated that all rūnanga that had takiwā overlapping with catchment boundaries had to be included on zone committees. The reasons for this provision are unclear given that documents from the developing stages of the CWMS identified Ngāi Tahu as one of multiple stakeholders (for example Whitehouse et al., 2006). It is possibly the result of a growing acceptance by authorities within the region of principles of partnership, and the importance of Māori knowledges (Tipa \& Welch, 2006). It may have also been a reflection of Ngāi Tahu's large landholdings; given that the CWMS emerged out of desires for more water for the agriculture sector, Ngāi Tahu was possibly seen as a key figure in considerations of how to go about getting "more water". Indeed, Joyce indicated that the iwi's commercial success had been a key factor in gaining access to other environmental decision making forums (see Chapter 5). It therefore seems likely that NTP's status as a key property stakeholder, in the narrow sense of having something tangible at stake (Purcell, 2009), was what led to the rūnanga roles on zone committees. To that point, most local authorities in the region had shown little desire to engage with the iwi and Ngāi Tahu worldviews.

Nevertheless, the CWMS' requirement for catchment committees to have rūnanga representation did prove to be an important step. More than representing simple inclusion, it served to set Māori apart from mere "stakeholders". When asked about his reaction to the conflict over the Environmental Services Committee, the Ngāi Tahu advisor to the HWZC described his disappointment at the time, but subsequent view that the CWMS offered the chance to work in respectful partnership with others:

It was so ridiculous that it sort of spoke for itself, you know. I wasn't glad to see it happen but I sort of thought it may have been a good thing that it happened and it got to those extreme levels of ignorance and evil as the Mayor of the District Council [at the time] has described it .... And falling on the back of that was the CWMS and so we've been able to come in and work shoulder to shoulder in respect with each other and then we'll hopefully make sure the bubble doesn't blow up again (Mikaere 21 February 2012).

Through the inclusion of rūnanga representatives, the Strategy established the foundations from which to contest Eurocentric dominance in the District. 
Importantly, once Ngāi Tahu were included in the Committee composition, iwi and rūnanga representatives drew on their extensive skills and capacity to shape the Committee process. Tipa and Welch (2006) state that if Indigenous participants in devolved democracy have had their capacity and knowledges eroded through colonialisms, it can be difficult for communities to adequately respond to environmental issues and take responsibility for comanagement. However, Coombes et al. (2012) argue that Indigenous people working within democratic processes are often highly skilled and effective, and this shouldn't be underestimated. At a broad level, the iwi have been active in articulating and pursuing a particular vision for freshwater. For instance, in 1999 Ngāi Tahu developed a freshwater policy statement that maps the iwi's relationship with freshwater, how they envision participating in decision making and the outcomes they want for water. The plan explicitly recognises the challenges presented by environmental forums that persistently privilege scientific and technocratic expertise over tikanga. It sets out an alternative vision for freshwater management that includes up-skilling for rūnanga members, monitoring and improving environmental outcomes, and it establishes specific objectives to address key priority areas such as mahinga kai and kaitiakitanga.

This work of the wider iwi was reflected in the proficiencies and skills of Māori HWZC members. Dialogue and collaboration were already key aspects of decision making within the iwi, according to Mikaere (21 February 2012), who stated 'we have to do that anyway; in our circles that's the way we do it' (see also Jojola, 1998). Already competent with processes focused on communication, Joyce, IThaka (the representative to the HWZC for Te Ngāi Tūāhuriri Rūnanga) and Mikaere were able to draw on their extensive and diverse experiences and knowledges built through rūnanga involvement in environmental decision making more broadly. Joyce in particular was recognised by a number of other Committee members for her ability to clearly communicate Ngāi Tahu ways of understanding and valuing the Hurunui River (Tim 14 February 2012; Hamish 16 February 2012; Duncan 20 February 2012). In many ways she represented a key broker in a 'bicultural hot-spot', skilfully facilitating communication and understanding between iwi and Pākehā (MoekeMaxwell, 2003). Having been an important figure in developing environmental plans and strategies in the takiwā of her rūnanga, particularly Te Korowai (see chapter 5), Joyce had substantial experience in learning-based, multi-party environmental decision making. Although "gifting and gaining" wasn't an approach formally adopted by the HWZC, Joyce's competence with the framework as a way of learning and making progress in Kaikōura 
meant she often referred to gifts and gains as a way to refocus the Committee (Field notes 19 September 2011). One Pākehā Committee member stated:

I think you couldn't do it [the Committee work] without [the rūnanga] and I think they've contributed quite significantly to that consensus ... that gifting and gaining, and at different times when we've been stuck, that gifting and gaining has been quite good to go back on. It's good (Brad 21 February 2012).

Mandated rūnanga representation and the experience and skill of the representatives enabled dialogue to take place that wouldn't have otherwise. In addition to learning about concepts at the heart of Ngāi Tahu's ways of knowing the Hurunui River, Committee members gained an increased understanding about the relationships and constant work within Te Rūnanga o Ngāi Tahu to develop an approach that met multiple needs. Where previously people viewed NTP and rūnanga as working in contradictory ways, the Committee increasingly understood the complex negotiations that were taking place in an effort to develop a unified iwi position:

I think [the rūnanga representatives] both got quite a bit out of it themselves, but they contributed a huge amount as well because ... I think they brought to the discussions the Committee was having what goes on inside Ngāi Tahu, where they're balancing the cultural issues versus their desire to have economic benefits as well. So what goes on inside Ngāi Tahu is very much what needs to go on in the wider community. So that came through and their contribution got bigger and bigger. And I think especially when we started to have community meetings and either [Joyce] or [Mikaere] fronted up and spoke at those meetings and I think that was a real positive as well (George 14 February 2012).

Understanding the debates internal to Te Rūnanga o Ngāi Tahu helped to illustrate the paradoxical space the iwi occupies as it negotiates how to articulate, advocate for and enact their worldview, while also navigating modernity and desires for economic growth and material care of iwi members within a corporate iwi structure. In making apparent these internal debates to Zone Committee members, the iwi couldn't be easily dismissed as out of place in contemporary debates about freshwater, an understanding of the iwi that was apparent during the conflict over the Environmental Services Committee and characterisation of the iwi as using 'myths and legends ... which is inappropriate for this 
age' (Hurunui District Council, 2009a, p. 15). Furthermore, concerns of "culture" couldn't be separated from economic, environmental and social considerations as Ngāi Tahu actively engaged with all of these values. It was more difficult, therefore, for the Committee to view culture as a historical concern that can be dealt with and then dismissed (Ayre \& Mackenzie, 2012; Jackson, 2006; Li, 2002).

The learning that took place on the Committee was seen to be significant by Mikaere, as respect and trust built to a point where different ontologies could be articulated and respected in the same forum. He stated that 'we're getting closer to a point of reflecting both of those worldviews in the same space' (Mikaere 22 July 2011), and therefore developing ontologically plural political spaces (Howitt \& Suchet-Pearson, 2006). Hutchings (2006) argues that the RMA framework is largely failing Māori, because it does not adequately create space to build respect for Māori worldviews. She states that 'further advances and movements of paradigms to allow for (bi)cultural management of the landscape will come from communities creatively exploring possibilities and opening space beyond the RMA and accepted norms of regulated environmental management' (Hutchings, 2006, p. 104). With the increased possibilities for dialogue and transformative social learning, the CWMS offered a space outside the RMA that resonated with existing ways of making decisions within Ngāi Tahu. Through dialogue and social learning worldviews were drawn into the same space to explore creative possibilities, such as the increased restrictions on the private property rights of land users (see Chapter 4).

\subsubsection{Beyond the HWZC - decolonising decision making}

However, like trust building (Chapter 5), cross cultural learning seemed to be largely limited to Committee members. At a meeting just prior to the release of the first draft of the ZIP, a member of the public who was both a farmer and irrigator stated that compared to pre-CWMS and ECan Act planning processes he hadn't received the same amount of information, or been involved in as much dialogue (Field notes 14 March 2011). He further stated that some communities felt excluded from the HWZC process. Indeed, some Committee members expressed great disappointment at the disconnection between the wider community and the Committee and their work (Field notes 30 May 2011). One Committee member stated that most people in the Hurunui Waiau Zone wouldn't have had Ngāi Tahu worldviews: 
brought to their attention. And they need to learn about [the iwi]. So I guess some of them have probably learnt but I'm not sure. That's possibly come through schools, through kids, but I'm not sure specifically through the Zone Committee ... I think when we went out into those communities and talked about our ZIP, and we talked about kaitiakitanga and we talked about cultural values, people suddenly went "Ah, I hadn't thought about that." So they were exposed to it. Whether they learnt a lot, I don't know (Shona 18 March 2012).

Another Committee member agreed that cross-cultural learning was limited, but that dialogue and understanding that did grow outwards from the Committee was important:

Amanda: Have you noticed a change within the community here in terms of how they think or interact with iwi?

Brad: Some, some. And it's probably a small minority .... It's the dialogue that changes people, and at the moment, the people that are having the dialogue, they're changing a bit.... it's an incremental step forward (Brad 21 February 2012)

The restricted scope of increased understanding within the wider community is an outcome of persistent understandings of Ngāi Tahu as one of many stakeholders, who needed to perform good economic citizenship to participate (see Chapter 5). It is also indicative of the instructions to the HWZC in relation to representation; as argued in Chapters 4 and 5, members were not responsible for and accountable to publics, nor were they required to be part of a wide ranging discussion that informs representation (Young, 2002).

But it is also the result of the time constraints placed on the Zone Committee (Field notes 19 September 2011). Time is an essential ingredient for creating dialogue, cross cultural learning and building understanding (Hoverman \& Ayre, 2012). Yet ECan commissioners directed the Committee to produce a ZIP in 12 months, and refused to ask the Minister for the Environment to extend the moratoria, which would have secured more time for ZIP development. One commissioner justified this refusal on the basis that it would be too 'messy' to do so and the Committee needed to 'get on with it' (Howard 23 February 2012). While collaborative processes offer valuable opportunities for Indigenous people to avoid top down (and Eurocentric) state approaches to planning (Hibbard et al., 2008), Tipa and Welch (2006) express concern about any devolved decision making process in which 
governments retain ultimate authority through political and legislative functions. As described in Chapter 4, ECan commissioners clearly retained authority and exercised this authority by intervening in the HWZC's work, and central government had already illustrated a willingness to interrupt and remake formal environmental politics. Despite important dialogue and learning, the HWZC was a 'relatively fragile construction' that existed in an uncertain political terrain which could be rapidly changed (Tipa \& Welch, 2006, p. 388). Regional and central governments' orientation towards outputs rather than processes, and willingness to intervene and disrupt existing processes (should the output be "wrong"), meant opportunities to engage the public, build trust beyond the HWZC and extend cross cultural dialogue were missed (see also Chapter 4). Ultimately power relations remained highly uneven, as governing bodies rooted in Eurocentric worldviews, mandated by Eurocentric legislation that fails in multiple ways to adequately serve Māori, retained the capability to intervene or ignore Zone Committee processes and outcomes.

As Howitt and Lunkapis (2010) and Porter (2010) argue, decolonising approaches to planning need to shift beyond considerations of how to best include Indigenous people (although these considerations remain important), and further challenge the ontologies underpinning, and Eurocentric laws and regulations ultimately determining, planning practices. Both Coombes (2007a) and Mutu (1994) argue that within environmental decision making processes in Aotearoa New Zealand much more needs to be done to build understandings of iwi worldviews, especially values based on spiritual understandings. In addition, as devolved decision making processes gain increasing favour, Coombes (2007a, p. 70) states that success rests on 'far greater respect for Indigenous management and institutions and acceptance of customary entitlements to natural resources'. Doing so means addressing questions of Indigenous sovereignty and ownership, as well as the way iwi structures are moulded to fit with colonial institutions and practices (Maaka \& Fleras, 2005).

(Post)colonial planners therefore have sought to encourage more fluid, open and situated processes that embrace difference and place specificity rather than privileging dominant, outcome orientated discourses, and dominant ways of making decisions about natures (Howitt \& Suchet-Pearson, 2006; Porter, 2010). For Howitt and Suchet-Pearson (2006) decision making processes need to begin with recognising Indigenous rights, needs for self-determination and increased Indigenous control over processes (Howitt et al., 2013). 
This also requires significant cultural learning, and increasing cultural competence by government authorities, as well as non-Indigenous communities. As illustrated by the Environmental Services Committee controversy, attempts to assert Māori rights were met with an alarming degree of cultural incompetence that remains inadequately addressed.

Political processes based on pluralism, as envisioned by anti-colonial geographers, also offer possibilities for non-Indigenous people to enact relational ethics and further contest the dominance of instrumentalist understandings of nature. This process-focussed approach to decision making resonates with Mouffe's (2000) work that seeks to imagine political practices that address uneven power relations and reject ambitions for universalising, rational solutions. Instead contestation is welcomed, but, like Ngāi Tahu's approach to the Hurunui River, is based on mutual respect and reciprocity. Indeed, Mouffe's concept of agonistic democracy is akin to the ontologically plural spaces for environmental decision making envisioned by Howitt and Suchet-Pearson (2006). Agonistic approaches are based on reciprocity and respect, shared ethical commitments between adversaries to be able to speak and to be able to be heard when articulating different values and understandings (Bond, 2011b; Mouffe, 2005). Genuine democracy, Mouffe (2000, pp. 65-66) states, requires a 'manifold of practices and pragmatic moves aiming at persuading people to broaden the range of their commitments to others, to build a more inclusive community' an inclusivity that also extends to more than human kin.

\subsection{Towards ontological pluralism}

Although significant work remains to develop planning processes than encourage ontological pluralism, the rūnanga members and the Ngāi Tahu advisor to the HWZC successfully contested dominant Eurocentric approaches to nature and the postpoliticising processes channelling these worldviews. In the face of the numerous expressions of western dominance, and uneven colonial power relations, Joyce, Īhaka and Mikaere were able to draw on their personal capacity, and that of an iwi negotiating multiple and at times competing desires, and engender a more responsible, relationship based approach to the Hurunui River. Space undoubtedly exists to extend understandings of the spiritual content of Indigenous worldviews (Coombes, 2007b) and there is a need for far broader community engagement with Indigenous cosmologies. For now Joyce has: 
seen [the Zone Committee] as a way to plant seeds and let them grow as opposed to giving it all and them picking it up and taking them on board and understanding. You've just got to plant seeds. Yeah. So I think we've done that, but there's still a lot of growing to do though! (Joyce 15 February 2012)

Ultimately for Mikaere, the Zone Committee process provided an opportunity to move on in some way from the conflict over the Hurunui District Council Environmental Services Committee, and develop relationships within the area that would be generative of improved ways of engaging with freshwater:

With the Zone Committee, we've been able to focus on just water and not all environmental sort of concerns for the Hurunui District Council, and water's the fundamental one anyway. It's allowed us to sort of leave that issue to the side and get on with working with the Hurunui District Council, and others in the District ... to improve the situation for something that's pretty crucial for us (Mikaere 21 February 2012).

Donna Haraway (1994, p. 62) argues that

[t]he point is to get at how worlds are made and unmade, in order to participate in the processes, in order to foster some forms of life and not others ... The point is not just to read the webs of knowledge production; the point is to reconfigure what counts as knowledge.

Just as more than human geographers have sought to envision and remake new worlds based on relational ethics (Haraway, 2008), Indigenous geographers and communities have sought to reconfigure already existing ethics as valuable knowledge within (post)colonial settings. As more than human geographers begin to acknowledge these already existing, situated knowledges, the Anglo European framework needs to further develop the complementary aspects of these geographies to build and support relational ethics for the more than human. But developing these geographies and more than human practices relies on acknowledging the highly uneven distributions of webbed power; within (post)colonial settings and across the range of "things", power continues to concentrate with colonial people, institutions and discourses (Kingfisher, 2007). 
In this chapter I have argued that more than human and Indigenous geographies can be drawn together in complementary ways to challenge ontological privileging in imagining environmental futures. Deploying both approaches offers situated examples of the ways relational ethics with more than humans are successfully enacted, while also provisioning a framework through which non-Indigenous peoples can also articulate respectful, reciprocal relationships. Non-Indigenous people involved with Hurunui decision making felt that they lacked the language to describe spiritual and kinship connections to the Hurunui River, instead resorting to scientific terms and concepts. There is, therefore significant scope for exploring how non-Indigenous languages for relational ethics might be developed in order to work towards ontological pluralism without appropriating and colonising Indigenous knowledges and concepts (Roberts et al., 1995). In developing a framework through which both Indigenous and non-Indigenous people might advocate for relational ethics, Sundberg (2013) argues that non-Indigenous people (and more than human geographers) might walk alongside Indigenous people. This involves active efforts to decolonise disciplines, decision making processes and politics, and recognise the multiple others that co-constitute the world. The complementary political and ethical projects of Indigenous and more than human geographies, therefore, represent hopeful ways to challenge neoliberal Eurocentric dominance, and develop more responsible environmental politics. 
192 | Reimagining environmental futures 


\section{Environmental democracy - accessing the Hurunui River}

Changes to environmental democracy in Canterbury, as explored in this thesis, are illustrative of shifts taking place throughout Aotearoa New Zealand. In July 2013 it was announced that a former ECan councillor, fired when the ECan Act was passed, had been appointed to a board of inquiry investigating potential irrigation schemes in the Hawke's Bay region on the East Coast of the North Island. The Conservation Minister, Nick Smith, who in 2010 was the Minister for the Environment involved in sacking ECan, was in charge of appointments to the Board. Minister Smith was questioned about the appointment, given the government's apparent lack of faith in the ECan councillors to resolve freshwater issues in Canterbury. His response was that the dismissal of the council was not about individual councillors, but the fact that ECan was split along pro and anti-irrigation lines. According to the Minister it was this difference and dissent that made the council dysfunctional (Radio New Zealand, 2013c). Two months later, the Department of Conservation had prepared a 32 page report for the Hawke's Bay board of inquiry, detailing their concerns about the impact of a dam on water quality. However, before it could be submitted, much of the report was deleted by senior managers in the department, a move that Ngāti Kahungunu, the iwi in the region, saw as an indication of central government withholding information regarding river health and intentions to push through water storage (O'Sullivan, 2013).

At the same time as dissent and debate were being both disregarded and actively constrained by the Conservation Minister, somewhat paradoxically, proposed national freshwater reforms advocated the extension of collaboration and consensus based processes to all regions (Ministry for the Environment, 2013a). The reform discussion document describes processes that closely resemble those rolled out under the CWMS. Within this context of rapidly changing freshwater management, this thesis provides a timely and important examination of environmental democracy. 
This chapter will summarise my findings with reference throughout to the central aim of the research - to explore how different understandings of the relationship between nature and society compete in the new water management regime of the Hurunui catchment and four supplementary questions that were identified in the first chapter and are outlined below. Drawing particularly on the findings presented in Chapters 3, 4, 5 and 6, the following section will address each of the supplementary questions. I will then turn to a broader consideration of environmental democracy and post-politicising processes, considerations that are situated within emergent theorisations of the state and its role in reregulating environmental democracy in post-politicising ways. Following this, given my social justice orientation, I ask how environmental politics and economies might be reimagined and enacted in ways that invite different nature/society understandings. I then describe the limitations of the project before summarising key contributions and future research directions, with a particular focus on drawing radical democratic theory and political ecologies together, and offer concluding thoughts.

\subsection{Summary of findings}

When asked to provide reflections on the HWZC process, all Committee members could readily identify the positive dimensions of their work. One stated that given the nature of the conflict over the Hurunui River, it was an achievement 'just getting everyone round the table and actually finally agreeing on the [ZIP] content and where we got to 'cause it's pretty unique I think' (Duncan 20 February 2012). Similarly another Committee member said the core success was 'a group of people with very widely held and strong views coming together' (Brian 16 February 2012). Through the process of coming together, talking with the wider community and reaching consensus, another committee member stated that 'we've got an outcome that everybody on the Committee at least can live with' (George 14 February 2012). However, as argued throughout this thesis, feelings of trust and increased understanding were predominantly restricted to the Committee members themselves. The extension of these benefits beyond Committee membership was inhibited, as a number of processes constrained engagement with alternative understandings of the relationship between nature and society. These limitations, as well as the successes of the HWZC, are described below with reference to the supplementary research questions. 
a) What are the implications of environmental reregulation in Canterbury for access to decision making about freshwater?

In Chapter 3, I argued that the ECan Act was an overt and alarming extension of the kind of state of exception described by Agamben (2005). Provisions in the legislation that suspended regional elections for three and a half years (later extended to more than six), limited access to the Environment Court, and interrupted processes seeking protection for the Hurunui River, represent an unprecedented and unconstitutional incursion on environmental democracy (Brower, 2010a, 2010b; Joseph, 2010). The effects of the ECan Act were to privilege technocratic expertise of appointed ECan commissioners over political diversity and debate between elected councillors (Cairns, 2012). Furthermore, dominant economic systems were sustained through changes to Water Conservation Orders, protection measures that were viewed by the Ministry for Agriculture and Fisheries as a barrier to 'investment certainty in Canterbury's rural economy' (Ministry for Agriculture and Forestry, 2009, p. 2). The Minister of Agriculture later threatened other councils in Aotearoa New Zealand that were seen to be obstructing the interests of agricultural water users (Burke, 2013).

Environmental reregulation constrained spaces for the kind of debate and expression of difference that can occur through the electoral processes of representative democracy and the justice system. In limiting individual democratic rights, the neoliberalisation of freshwater can be more easily progressed - councillors advocating for water bodies were removed, access to WCOs changed and opportunities to contest decisions through the Environment Court restricted. The intervention by central government was motivated by perceived obstacles to neoliberal growth to be attained through agricultural irrigation, an agenda that is further evidenced by recent events in the Hawke's Bay. By drawing together political ecology and radical democratic theory, it was possible to make sense of the ECan Act as an example of post-politicising reregulation that sought to channel neoliberal natures and suppress formal democratic dissent.

Another aspect of reregulation was the endorsement of the CWMS by the ECan commissioners, and through the ECan Act, as the primary framework for determining the future of freshwater bodies. The Strategy was problematic in that it lacked clear regulatory standing, and some outcomes, such as securing "more water", were predetermined, limiting who and what was considered legitimate within the HWZC space 
(see research question b). However, the Strategy did enable greater iwi access to decision making about the Hurunui River as it recognised the need for Indigenous representation (see below in relation to research question c). This was very important in a District that had been characterised by racist debates about environmental decision making. Furthermore, iwi representatives were seen to be influential in shaping the HWZC's process and outcomes. However, the application of consensus and collaboration through the CWMS framework had mixed success.

b) How have consensus and collaborative decision making processes affected the nature of democracy and conflict in the Hurunui?

Despite assurances that the CWMS, and the zone committees established under it, would provide the region with improved environmental democracy (The Press, 2010), the HWZC was plagued by a number of characteristics that radical democratic theorists warn against (see Chapter 4). Firstly, the very goal of resolving freshwater conflict through consensus was demonstrated to be problematic, and in particular the fact that consensus needed to be based on a number of predetermined outcomes (Lomax et al., 2010). One of these outcomes was "more water", which contributed to a dominant environmental imaginary that limited possibilities for other meanings of the Hurunui River to be heard, and viewed as legitimate, by the HWZC. For instance, those that tried to contest the "more water" discourse were only able to be heard as rational, and therefore legitimate, if they presented an alternative large scale water storage option.

Secondly, for collaborative processes to be successful, power relations must be explored and unevenness addressed (Walker \& Hurley, 2004). The HWZC didn't adequately do so and as a result, ECan was able to intervene and redirect the collaborative process when it seemed likely that short term economic gains would be troubled (see Chapter 4). This intervention, although dismissed as insignificant by one ECan commissioner, threatened to derail the entire CWMS process. In addition, members of the public who had initially been hopeful about the possibilities of collaborative approaches, felt disillusioned and disempowered. Exacerbated by the state of exception, ECan's intervention left many people without recourse to meaningful environmental democracy; the outcomes of the HWZC's recommendations and the subsequent planning hearings could not be appealed based on content, only on points of law, and neither the ECan commissioners nor HWZC members could be held to account through public elections. HWZC members were 
instructed not to act in a representative manner, and therefore they were not compelled to engage in wide ranging public conversations that would generate authority to act for the public, and hold Committee members to account (Young, 2002). As a result, the Committee was, at times, somewhat disconnected from the public.

Aspects of the HWZC's work were, therefore, illustrative of critiques of communicative planning (Mouffe, 2000, 2005), particularly its failure to critically engage with uneven relations of power within both formal and informal political spaces (discussed below in relation to research question c), and question the dominance of neoliberalisms (Purcell, 2009). The HWZC, and the CWMS process broadly, missed opportunities to develop a deeply democratic approach to the Hurunui River conflict, an approach that created space to respectfully explore different understandings of nature and alternative routes to achieving a vibrant community.

Nevertheless, the HWZC's work also demonstrated the ways that political closure is subtly contested and troubled. In particular, opportunities for learning were deeply important for cultivating trust and understanding amongst Committee members, and also generated more responsible provisions for protecting the river. For instance, the Committee recommended that water users join catchment groups who are accountable for keeping river nutrient loads within certain limits (see Chapter 4). Changed land use that results in breaches of the load limits requires a resource consent for continued land use, a novel provision in a country that reveres private property rights (Wilson \& Memon, 2005).

Drawing on these contestations of closure, I argue for an understanding of postpoliticisation as a multi scalar process, an understanding that opens space to acknowledge the dynamic relations that both constitute and resist the disavowal of dissent. This understanding of post-politicising processes was further extended through an exploration of everyday experiences of power in the Hurunui District.

c) How do power relations affect access to public debate about the future of the Hurunui River?

In addition to analysing how power was deployed by the state to limit opportunities for dissent and disagreement (see above), I explored how power laden community relations shaped debate about the Hurunui River. In Chapter 5, I examined the ways that constructions of community, and norms that governed "good" community performance, 
worked to exclude and silence certain voices. In particular, spatial definitions of belonging, combined with expectations of individual consumerism within District boundaries, represented an attempt to render illegitimate the voices of those who lived outside the Hurunui District and resisted water storage. Those who did live inside the District were expected to perform according to gender, class and social norms that effectively constrained opposition to damming the river. For instance, a number of women in the District were reluctant to voice opposition to a dam, as this would bring into question their roles provisioning for, and supporting, farm based family members and the community (Liepins, 1998). These constructions of belonging and expectations around community performance were policed, and those that were found wanting were disciplined. These relations of policing and disciplining illuminated power hierarchies in which landowners could exclude labourers and contractors for expressing divergent politics, women felt disempowered to dissent from their husbands' perspectives about damming the Hurunui River, and local policemen reinforced the disciplining of anti-storage voices.

These practices were a reflection of what was seen to be at stake - as one participant stated, securing water storage was an issue of survival (Donald 21 February 2012). People wanted a vibrant and economically self-reliant area. Many community members held deep seated desires to do what they could to boost school numbers and create jobs that would retain young people. To achieve these goals, neoliberal economic growth through agricultural irrigation was seen to be the best, if not only, avenue. However, disciplining practices limited opportunities for informal democratic practice and agency, restricted access to the HWZC and also constrained opportunities to discuss alternative ways of achieving a vibrant community. The experiences of those who were disciplined and policed out of Hurunui politics illustrate the importance of everyday power relations, and how they shape access to environmental governance. This is an area of political ecology that feminist theorists have recently developed (Elmhirst, 2011; Sultana, 2009, 2011). Disciplining and policing also highlight the work required to disavow dissensus and bring about and sustain post-politicising processes.

This research also demonstrates the ongoing disjuncture between literature that argues against privileging community as a scale of decision making without reflexively engaging with power or the ways that people seek to fix community identity, and planning design that continues to work on the assumption that local democracy is inherently superior 
(Panelli, 2003; Tewdwr-Jones \& Allmendinger, 1998; Walker \& Hurley, 2004). This gap is indicative of a broader need to develop understandings of power within democratic design to reflect its ever-present nature, and the ways that power circulates through all scales and yet concentrates unevenly. The HWZC exhibited a reluctance to engage with uneven power at a community level, with the ECan commissioner to the Committee dismissing practices of disciplining as beyond the ambit of Committee work.

Understanding power as able to be neutralised, as is characteristic of communicative planning, typically results in the dominance of those who already possess privilege (Young, 1996). Therefore, if unequal power relations remain unexplored, as in the case of the HWZC, collaborative planning processes risk simply providing the banner of democracy, legitimising uneven access to nature and leaving unchallenged antagonistic processes of community identity formation. The uneven power relations in Hurunui politics, and the dominance of "more water" discourses, were, however, resisted and troubled.

\section{d) How are dominant understandings of nature/society relationships contested?}

Despite the problematic nature of aspects of the HWZC and broader processes occurring in the region, the Committee space did enable dialogue, and therefore there were opportunities to contest work to channel the neoliberalisation of nature. As explored in Chapter 4, sharing perspectives and learning about others were seen as the most valuable aspects of Committee work across the ten catchment committees established under the CWMS (Bestwick, 2012). For the HWZC members, significant learning about Ngāi Tahu took place. In Chapter 6, I charted the ways that through dialogue Committee members came to have a greater understanding of and respect for Ngāi Tahu's worldviews. As a result, the rūnanga representatives were successful in beginning to enhance responsibility for the Hurunui River by emphasising kaitiakitanga and a whole of river approach through the Ki Uta Ki Tai philosophy. Through this relational understanding of the world, dominant instrumentalist understandings of nature as a series of discrete objects, primarily valuable for economic growth, began to be contested. The opportunities for exchange and discussion that were created through the CWMS and the HWZC were viewed by rūnanga and iwi representatives as an essential component for shifting beyond the racist conflict over representation on the Environmental Services Committee, and for cultivating different relationships between Māori and non-Māori, and with the river (Mikaere 21 February 2012; Joyce 15 February 2012). 
Herein lies the potential of democratic processes that focus on dialogue - spaces are created in which transformative social learning can take place (Bond \& ThompsonFawcett, 2007), and post-politicising processes, and "there is no alternative" discourses, can be troubled. Such spaces are particularly important in (post)colonial settings, given the urgent need to build cross cultural competence (Howitt et al., 2013). Building this competence is a responsibility that rests not with Indigenous people but with the institutions that are established within, and perpetuate the dominance of, Eurocentric ways of being in the world. In its freshwater reform discussion paper, the Ministry for the Environment (2013a) acknowledged the need to greatly increase engagement with iwi. Whether this translates into democratic processes that begin from a recognition of Indigenous rights remains to be seen (Porter, 2006, 2010; Prout \& Howitt, 2009). (Post)colonial planners, Indigenous geographers and radical democrats envision decision making that starts from rights recognition, rejects an orientation towards outcomes and is instead situated within particular contexts, and is open and inclusive of multiple ways of understanding the world (Howitt \& Suchet-Pearson, 2006; Mouffe, 2000, 2005; Porter, 2010). Open and situated democratic processes may also provide greater opportunities for non-Indigenous people to articulate non-instrumentalist understandings of nature. However this was not often the case for those engaging with the HWZC, a space in which non-Māori who described relational ethics for the river were not seen to be rational in the same way as rūnanga representatives were.

In the face of post-politicising processes, a range of activists attempted to contest the dominance of neoliberalised nature/society understandings both on the HWZC and beyond. Through the cultivation of networks, public art and protest people sought to generate conversation about different understandings of nature. At times these efforts were successful, for instance the public backlash to ECan's interference in the HWZC process over nutrient loading limits. At other times, activists felt constrained by the state of exception, and energy was consumed by the Canterbury earthquakes and their aftermath. Yet their activism illustrates that despite the labour invested in disavowing dissent and disagreement, post-politicising processes are incomplete.

One way that dominant understandings of nature were, to a degree, successfully contested was through the work to shift the location of water storage off the mainstem to the Waitohi Valley, a location that was seen to have a lessened impact on the 
environment and sites of importance to tangata whenua. As a result, securing "more water" has become more complicated. At the time of writing, the first of four stages of the Waitohi scheme had just received approval to proceed (see Chapter 4), and in September 2013 HWP secured \$2.4 million from the Ministry of Primary Industries to undertake further feasibility studies. Yet it's unclear how the remainder of the project will be funded. The predicted financial cost of accessing water has soared with the changed storage location (Keene, 2013), meaning that if the water is too expensive for farmers the scheme may become unfeasible. It is, therefore, possible that the work of activists and iwi members who opposed damming the Hurunui mainstem might be successful in preventing any large scale Hurunui water storage, despite all of the central and regional government intervention to try to channel large scale storage. However, judicial review hearings that contest aspects of the Hurunui Waiau River Regional Plan on points of law are yet to be heard in the High Court. If HWP's case against the zoning of the Hurunui mainstem (zoning that prohibits any storage on the river) is successful, consent applications for the South Branch and Lake Sumner schemes may be reactivated. Should this scenario eventuate, the future of the CWMS and its committees may be very uncertain, given that Hurunui River politics would be in much the same situation as they were prior to the HWZC's work. Through the dialogue developed in the HWZC space, and ongoing activism outside formal politics, attempts to disavow dissent and disagreement were troubled and dominant approaches to the river subtly contested.

Nationally, ambitions for "more water" are relentless, and the possibilities for open decision making that is inclusive of difference and dissent are increasingly limited. It is to these processes of narrowing that I now turn, and how they might be understood within a political ecology framework. In the following section, I examine current processes that illustrate the necessity of a nuanced examination of environmental democracy at the state level, and beyond.

\subsection{State of the environment - post-politicising processes and political ecologies}

The role of the state has remained largely under conceptualised in political ecology literature (Ioris, 2012), a gap that I have argued can be addressed by drawing on political theory, and a task I contributed to through an examination of the ECan Act. While the 
intervention in Canterbury was, and remains, unique in Aotearoa New Zealand, there are other state processes that are actively limiting democratic rights and participation in environmental decision making. Recent national reforms have worked to smooth the way for commercial ventures by changing when and how the public can engage with and contest state decisions. In March 2013 the central government announced a law change that would restrict protest at sea. The change was provoked by demonstrations against oil exploration in the eastern Bay of Plenty in 2011. The new law means that similar protest action is a criminal offence punishable by a large fine and imprisonment (Davison, 2013; TVNZ, 2013). Following this controversial reform, the government released a discussion document that proposed amending maritime law through the Marine Legislation Bill. The amendments would change the consent status of applications for deep sea oil and gas exploration, and thereby remove the public's ability to use formal channels to oppose applications for exploration permits (Stuff.co.nz, 2013). The Minister for the Environment stated that the changes would balance protection of the ocean with commercial concerns to avoid 'excessive costs and extended timeframes' (Stuff.co.nz, 2013). In 2013, central government also proposed an extension of their ability to intervene in regional and local environmental decision making. Suggested reforms to the RMA would effectively hollow out aspects of territorial authorities' roles; a newly established body of Crown appointed officials would hear consent applications considered to be of "national significance", and applications would be assessed against measures increasingly orientated towards economic growth (Kedgley, 2013; Oram, 2013; Taylor, 2013). The proposed reforms have been critiqued by one of the architects of the RMA for, amongst other things, '[p]rioritising the rights of land-owners over the rights of the public to enjoy a clean natural environment' and for having the potential to 'significantly restrict the ability of ordinary New Zealanders to have their say about the environmental and recreational impact of development' (Palmer, 2013).

These changes to environmental management come from a central government that is increasingly under fire for a general disregard for democracy, with one commentator stating that what 'we are seeing seems to be an authoritarian, centralising Government reluctant to share decision-making with citizens' (Wetton, 2013). This reluctance to share decision making is also illustrated by a discursive narrowing of democracy, which is increasingly constructed as something that happens once every three years during parliamentary elections (see Diane Revoluta, 2012). Furthermore, parliamentary processes 
have been increasingly circumvented in ways that limit opportunities for public engagement. While the use of parliamentary urgency to rush through legislation has been a cause for concern in Aotearoa New Zealand for at least two decades (Joseph, 2010), alarm has mounted recently. In a 2013 report to the United Nations, the New Zealand Law Society expressed disquiet about the use of urgency to pass laws, as well as recent legislative changes that were diametrically opposed to the rule of law, and breaches of the Bill of Rights Act (see, for instance, The New Zealand Herald, 2013). Aotearoa New Zealand anthropologist Dame Anne Salmond (2013) writes that when a body as 'authoritative and dispassionate' as the Law Society expresses such concern 'all New Zealanders should be very worried'.

These alarming intrusions on democracy, and particularly the possibilities to participate in formal and informal environmental democracy, demonstrate the important role of the state in neoliberalising natures. Globally, such encroachments on possibilities for participation and individual rights have become increasingly visible as states aggressively protect and advance neoliberalisms (Dahmann et al., 2012). Rather than growing individual freedom and autonomy from state control, as promised in neoliberal discourses, states have progressively become embedded in a range of practices and organisational forms (Amin \& Thrift, 2005). The emergent focus on states' roles in securing neoliberalisms has been sharpened by the global financial crisis. Clarke (2010, p. 387) argues that even though 'the scale, scope and even causes of the economic crisis are widely understood as 'global', the effects of, and responses to it, have been primarily defined in national terms'. It's states that have bailed out failing businesses and borne the costs of the crisis, and it's states that have deployed their security forces and reregulated to protect neoliberalising processes. According to Adey (2009), in the face of uncertainty about the economic system, more and more states have turned to pre-emptive policies that seek to outflank possible resistance or threats to neoliberalisms. These pre-emptive politics represent a form of biopolitics whereby the state adopts modes of rule that attempt to ensure docility (Foucault, 1990). Biopolitics is concerned with sustaining and administering capitalist economic life, based on the construction of particular natures that are separate and primarily valuable as a source of economic growth.

The implications of biopolitics for accessing natures have become ever more salient within discourses of environmental crises (Swyngedouw, 2013a). For instance, Featherstone 
(2013) describes how prior to the United Nations climate negotiations in Copenhagen in 2009, Danish parliamentarians rushed through legislation that criminalised peaceful protest. The law suspended the rights of people protesting climate injustice who the state suspected would break the law in the near future; people could be detained for twelve hours based solely on this suspicion, and protestors could be jailed for forty days. Over 900 protesters demanding system change were arrested and held under this pre-emptive legislation. Some were detained for more than three weeks without being charged (Vidal, 2010). Similarly, Aotearoa New Zealand's policies limiting protest and public participation in decisions about offshore oil exploration, pre-empt protests or dissent that might threaten commercial interests and the privilege extractive primary industries currently enjoy.

Such pre-emptive policies, regulations that suspend democratic rights, and securitisation are part of broader post-politicising processes. The implications of post-politicising processes in terms of environmental decision making have been illuminated by explorations of climate change. There is growing acceptance amongst academics that humans have become a geological force, changing the climate and the trajectory of evolution. This has led to declarations that we have entered the "Anthropocene", a new epoch (Crutzen, 2002). Climate scientists argue that humans need to reduce carbon dioxide emissions to zero within the century to have any real effect in averting the worst impacts of a dramatically warmed planet (Sington \& Lamb, 2013). Yet there is little public debate about the economic and political systems that lead us deeper into the Anthropocene. Instead debates are increasingly rendered non-political; climate change is a technical and scientific problem, to be "managed" through economics and outside of politics.

In response to the threat of climate change, political theorists have argued for remade politics that invite difference and cultivate public imagination of environmental futures (Karlsson, 2013). Swyngedouw (2013b, p. 2) argues that 'if we really care deeply about the climate and other socio-environmental conditions, our theoretical gaze and political passions have to shift from a concern with the environment per se to a concern and passion for the construction of a different politics'. The radical democratic vision of politics is one that is 'ruptural and inaugrative ... [a] politics that starts or introduces something new, perhaps unexpected, and interrupts the established order of things' (Dikeç, 2012, p. 
670). According to Žižek (1999b) and Rancière (2001) for action to count as politics, it must be ruptural to the extent that it remakes entire social frameworks. However, as argued in Chapter 4, this emphasis on remaking everything presents an unnecessarily preclusive definition of what kinds of politics matter. In that chapter, I charted the emerging critiques of theorisations of post-politicisations and the state. These critiques draw on inter-scalar processes and everyday life to illustrate the way that post-politicisations are already contested, challenged and defeated. It is to these critiques, and what they mean within a political ecology approach that I now turn.

\subsubsection{Looking beyond the state}

There are three central and related critiques of post-politics which I have extended through my case study, and that call for greater nuance within a theorisation that has totalising tendencies. Firstly, drawing on Chatterton et al. (2012) and McCarthy (2013), I have called attention to the work that is carried out to disavow politics and dissent, and channel neoliberalisms. Here this work was made apparent through the construction and performance of bounded notions of community, through ECan's intervention when the HWZC attempted to limit nutrient loading in rivers, and through the ECan Act itself. These processes all required significant labour in order to facilitate the enclosure of freshwater for neoliberal economic growth. I have therefore contributed to radical democratic literature by arguing that post-politics is not a diagnosable "condition", but takes the form of processes that require work by many actors who experience and deploy power in a number of ways. Acknowledging it as such creates space to explore how post-politicising processes are, and might be, interrupted, disrupted and defeated.

This is linked to the second core critique, which is concerned with theorisations of "authentic politics". An authentic politics that is momentary, and/or must remake the entirety of social frameworks (Rancière, 2001; Žižek, 1999b), leaves very little space to engage with actually existing contestation and dissent (and thereby, contributes to postpoliticisations) (Featherstone \& Korf, 2012). Rather, in adopting a poststructural feminist political ecology approach, I have critiqued such totalising definitions of what counts as meaningful political action. As such, I created space in which to acknowledge and explore the ways that neoliberal trajectories were troubled and contested. The Zone Committee and the activism of members of the public certainly didn't "explode" post-politicising 
processes (Swyngedouw, 2013b). Moreover, further closure continues to take place as noted above. But for the Zone Committee members who learned about other ways of being with and understanding the Hurunui River, their empathies for (human and nonhuman) others grew in ways that were expressed subtly through the ZIP and the collaborative process itself. During my final semi-structured interview for this project, I asked a Committee member why she cares about the Hurunui River. She answered:

Because I understand it differently now from what I did before. I understand that it's just not a matter of taking some water out of it and using it, and growing grass and feeding animals, and from that comes a product that we can sell and make some money. (Pause) The water cycle doesn't work like that ... I care because if we don't address these issues about our rivers and come up with, based on the best information we've got now, a way to manage them, then we're going to have some problems with many of our rivers, not just the Hurunui or the Waiau, longterm (Shona 18 March 2012).

Although Shona didn't contest the perceived need for large scale Hurunui water storage, it's impossible at this point to know the full implications of how changed understandings of the river might shape future decision making, or even everyday interactions with others, both human and more than human.

Thirdly, radical democratic theorists have largely focused on the state as a scale of analysis. While I have argued that there is significant work to be done exploring how states advance neoliberalisms in ways that constrain access to nature, this attention shouldn't be at the exclusion of other scales, or indeed cross-scalar politics (Featherstone, 2013). In exploring national, regional, district and household environmental politics, I have drawn attention to both the multiple processes required to channel neoliberalisms, as well as the ways these processes are contested. Ben's art-activism, Julia's solidarity with rural women, Ruth's petition, and the large network that grew around water politics that was described by Louis (see Chapter 5), all indicate the ways in which the public are active in complicating and resisting narrow environmental trajectories. Ignoring these politics presents post-politicising processes as more unified and coherent than they are.

Given these critiques, what does it mean to draw theorisations of post-politics into political ecologies? In this thesis I have argued that post-politicising processes need to be 
identified and contested. Doing so is an important task for political ecologists seeking to make sense of how certain understandings of the environment are privileged over others, and the implications for accessing nature. Yet there is a need to engage with these emerging critiques, and develop more careful, nuanced conceptualisations that acknowledge contestation and creation at multiple scales, in addition to exploring the complex, labour intensive relations that constitute post-politicising processes. I have argued that this nuance can be developed through feminist political ecologies that are attentive to multiple scales, and everyday experiences of power.

\subsection{Learning to live together - geographies of coexistence}

In Chapter 2 I positioned myself as centrally concerned with social and environmental justice, and explorations of how more just modes of life can be cultivated. It's therefore important to shift beyond a focus on critique, something geographers of the left are often accused of failing to do (Smith, 2009), and consider how to address the very real and legitimate concerns, needs and desires of communities facing difficult and multiple pressures, as well as stresses on the biophysical world. The need to explore and enact alternative ways of being with co-constituted others is becoming increasingly apparent as reliance on neoliberal forms of economic growth fails to provide the vibrant rural communities desired by people. In fact, evidence increasingly suggests that agricultural intensification is leading to more transient rural populations, and growing corporate ownership (Memon et al., 2012), not the family based settlements that are seen to be so important to sustaining ruralities, as described in Chapter 5. Furthermore, not only are neoliberalisms exacting costs on natures, rural people are bearing the personal brunt of reregulation and market privilege. The current economic model, and particularly a poorly regulated banking sector, sees many farmers take on enormous debt. In the past decade rural debt has grown from $\$ 18$ billion to $\$ 50$ billion (Wane, 2013). Such debt leaves rural communities exposed to fluctuating globalised markets. This vulnerability manifests in a number of forms, including the loss of family farms and reduced personal wellbeing. In the three years following the 2008 global financial crisis, suicide rates amongst farmers doubled, and are now 50\% higher than urban areas in Aotearoa New Zealand (Wane, 2013). 
However, shifting beyond dominant (neoliberal) economic formations and ways of relating to the environment can be difficult. Discussing the difficulties of change, one HWZC member stated:

how do you deal with the farmer who's just invested $\$ 5$ million in building a dairy farm based on the old set of rules, done exactly what he thought he should do, borrowed a huge amount of money to do it, and suddenly you say, "Well, sorry. The rules have changed. We know that your particular farm happens to be contributing $x$ amount of nutrient into the river and you have to stop". You can't do that (George 14 February 2012).

Here the work of feminist economic geographers J. K. Gibson-Graham (2006, 2008; Gibson-Graham \& Roelvink, 2009) is deeply informative in envisioning how political economic shifts might begin. They encourage people to think about the economy differently, beyond capitalism. They task scholars with taking an active role in thinking and communicating diverse, experimental economies. Along with other authors, they have worked to create a 'heightened economic sensibility' that 'catapults multiplicity and economic differentiation to the fore' in order to contest embedded "there is no alternative" discourses and instead consider diverse possibilities (Gibson-Graham \& Roelvink, 2009, pp. 329, 330). Alternatives, Gibson-Graham (2006; Gibson-Graham et al., 2013) suggest, can be based around community economies that are guided by ethical considerations. These are considerations that include questions of nonhuman wellbeing. In Aotearoa New Zealand, there is currently a focus on trade-off economics; quantifiable and privileged economic growth needs to be weighed against less quantifiable costs to nonhumans and humans, and non-instrumental ways of valuing nonhumans. For instance, in discussing mineral exploration and possible mining in conservation land, the Conservation Minister stated that we need to find out what 'resources we have and then, as a country, we can make better informed decisions about the tradeoffs between conservation values and jobs from minerals development' (Bennett, 2013). GibsonGraham argue for economies in which natures aren't oppositional, but rather economies that rest on understandings of environmental complexity and nature/society coconstitution.

For communities in Canterbury, this would necessitate rethinking efforts to accelerate freshwater enclosure that further the ontological division of nature and society, and 
instead engage more meaningfully with different worldviews that are attuned to less tangible values (that will not necessarily contribute to neoliberal economic growth). This requires experimentation beyond traditional models of farming, experimentation that is increasingly necessary as multiple environmental challenges, such as soil loss, are generated by intensification (Houlbrooke et al., 2011). Such experimental agriculture based on a relational ethics for more than humans is not merely an intellectual abstraction. Through a case study of Australian farming, Gibson-Graham and Roelvink (2009) demonstrate how agriculture based on a respect for nonhumans provided a means for economic self-reliance similar to that desired by the Hurunui and Waikari residents interviewed for this project (see Chapter 5). This autonomy was achieved without large scale storage of "more water". In an Aotearoa New Zealand setting, Bargh (2012) argues that Māori-led diverse economies illustrate already existing alternative ways of negotiating the intersections of economy, environment and politics. These examples demonstrate that there are alternatives to neoliberalisms, alternatives that cultivate respectful relations with environments. The increased respect for Indigenous relational worldviews on the HWZC suggests a preliminary step towards developing such alternatives.

\subsection{Limitations of this research}

This thesis offers a snapshot in time of ongoing processes and, therefore, is limited in a number of ways. The HWZC is still active, and there is uncertainty both about how the Hurunui Waiau River Regional Plan will be implemented, and the role of the HWZC within it. Furthermore, there were nine other zone committees, each with varied experiences of navigating the post-ECan Act regulatory terrain. In terms of the research process, as detailed in Chapter 2, the research was limited in some ways by a lack of funding and I was therefore under pressure to both finish quickly and was constrained by the costs of travel. The latter meant that I attended every other HWZC meeting, rather than all of them, and was limited to some extent in my ability to spend time accessing wider community views within the District. In particular, time pressures meant that I had to defer presenting my work to the communities I researched with through a public forum and findings reports until after the thesis was submitted. At the time of writing, planning for the forum is underway. In addition, the initial project was planned for one year, rather than three, 
which meant that prior to beginning this research I was unable to develop a working relationship with Ngāi Tahu, and empower the iwi to shape the project from the outset in a way that meets the feminist ethical standards I adopted and the decolonising research praxis I sought to develop. Every effort has been made to acknowledge and take account of these limitations so that they have, therefore, had a minimal effect on the trustworthiness of this project (Mansvelt \& Berg, 2010).

This research was carried out from a poststructural feminist orientation that recognises that knowledges are situated and partial (Bondi, 2009). While some might argue that this research brings my own political positioning explicitly into view, the foregoing is not to say that I'm anti-dam or anti-development per se. Rather, I'm critical of a process that assumes there are no alternatives to large scale water storage, and the power relations that perpetuate this discourse of inevitability. Instead, I support democratic processes that begin from a questioning of power inequalities, and thereby reject the dominance of any particular nature/society understandings. This vision of democracy acknowledges and embraces difference and dissent and yet works to build relationships of respect, and invites a plurality of ontologies. Given that knowledges are situated, I am open to and inviting of different readings of the case study.

\subsection{Contributions and future research}

In this thesis I have made a number of contributions to existing bodies of literature. In a novel application of Agamben's (2005) concept of the state of exception, this project has explored the suspension of individual rights to facilitate the enclosure of nature (see Chapter 3). I have therefore contributed to theorisations of the state within political ecology. By drawing the work of Agamben and other radical democrats into a political ecology framework (Mouffe, 2000, 2005; Rancière, 2001), I have also developed emergent case study literature exploring the intersections of natures and post-politicising processes (see Celata \& Sanna, 2012). There is significant scope to extend analyses of the role of the state in privileging certain meanings of nature/society relationships. In particular, future research could explore how this privilege is enacted through the extension of the state of exception and the limitations that are therefore placed on genuinely democratic spaces for debating environmental futures. Such a research agenda is particularly needed in Aotearoa New Zealand given recent and ongoing policy changes. 
This project has also adopted a feminist political ecology approach that is attentive to the multiple scales at which politics take place and power is experienced. Peet et al. (2011) have argued that examining such relations is imperative to understanding and resisting neoliberalised natures. In addition to drawing important attention to the way informal political spaces shape formal spaces of community based collaboration, exploring everyday experiences has added nuance to radical democratic theorisations (see Chapter 5). Examining experiences of and the labour required to limit spaces for dissent has highlighted the processes that form post-politicisations. Throughout this thesis I have developed a conceptualisation of post-politicisation that has greater utility for political ecologists than the totalising and state centric tendencies of many radical democrats (see Chapter 4; McCarthy, 2013). Future research might further develop this conceptualisation, in particular through case study driven inquiry that examines the work required to disavow politics in decision making about nature.

In the face of alarming post-politicising processes, I have also advocated relational ethics for more than humans as one avenue for reimagining environmental futures beyond dominant binaried, hierarchical, neoliberalised nature/society discourses (see Chapter 6). By doing so, I have also contributed to the work of decolonising more than human geographies (Panelli, 2010; Sundberg, 2013), and added to calls for continued work by non-Indigenous institutions and people to build cross-cultural understanding (Howitt et al., 2013). Questions remain about the forms that relational ethics take, and how they might be brought into democratic spaces particularly in (post)colonial settings. As well as institutional recognition of rights, and the capacity and skill of Indigenous people and tribes, future research might explore other important factors that decolonise environmental decision making and support Indigenous people. How are the intersections and oppositions between Indigenous more than humanisms and neoliberalisms negotiated? For non-Indigenous people, how can democratic spaces be created for decolonising relational ethics? Relatedly, future work could usefully explore the links and synergies between radical democratic pluralism and agonism, and the kind of ontological pluralism advocated by (post)colonial scholars. Doing so could counter critiques of the western orientation of radical democratic theory (Dhaliwal, 1996; Slater, 2006).

Finally, I built on the work of Aotearoa New Zealand geographers who are attentive to processes of neoliberalisation (Bargh \& Otter, 2009; Larner \& Craig, 2005; Larner et al., 
2007; Lewis, 2012), and extended this body of work by drawing together political ecology and political theory to understand how neoliberalisms have been extended into the biophysical world in this country. Through documenting changes to freshwater management in Canterbury and the HWZC process, I contributed to empirical examples of the reregulation and enclosure of nature.

\subsection{Conclusions}

Amanda: Why do you care about what happens to the Hurunui River?

Brad: ... I don't really care about the river, it's the process. I think if the process works, then the river will be looked after, so yeah [laughs] I don't care about the bloody river (Brad 21 February 2012).

This thesis has asked how different understandings of the relationship between nature and society compete in new processes for making decisions about freshwater in the Hurunui catchment. In adopting a political ecology approach that is deeply informed by poststructuralism, I have explored the diversity of understandings of the Hurunui River and peoples' relationships with it. With a particular focus on unevenly networked power relations, I have argued that the CWMS within the ECan Act regulatory landscape did not create adequate political space for these diverse understandings to be articulated and enacted. Instead, neoliberal understandings of nature, and desires for economic growth, were privileged throughout. This privileging was apparent through national, regional and district level policies and processes, and discourses of "more water" in aid of economically self reliant communities. The ways that environmental democracy was limited in Canterbury, and increasingly in Aotearoa New Zealand, is alarming for those seeking to reimagine environmental futures beyond neoliberalisms.

For genuinely democratic environmental decision making, everything must be up for debate and contestable throughout the process, uneven power relations must be acknowledged and engaged with, and community cannot be deployed unreflexively as a superior location of democracy. In the case of the CWMS and HWZC, a deprivileging of community, a broadening away from "more water" rationalities and further cultivation of dialogue would be required to fully realise the possibilities of localised collaboration. Yet I have also argued that the dialogue that did take place was suggestive of possibilities for 
democratic processes that take ontological pluralism seriously, through which people might develop shared ethical commitments to the right to speak and be heard, and hinted at the kind of process that cares for the Hurunui River, as suggested in the quote above. As such, there are hopeful gaps and openings into which engagement and learning between multiple understandings can and did take place, and into which the seeds of more respectful and reciprocal understandings of multiple others, including nonhumans, might develop. 


\section{Appendices}

\subsection{Appendix A - Human ethics approval}

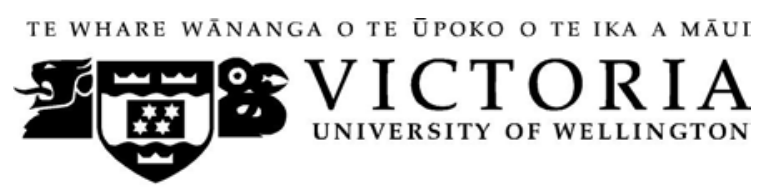

MEMORANDUM

Phone $\quad 0-4-4635676$

Fax $\quad 0-4-4635209$

\begin{tabular}{l|l}
\hline TO & Amanda Thomas \\
\hline COPY TO & Sophie Bond \\
\hline FROM & Dr Allison Kirkman, Convener, Human Ethics Committee \\
\hline
\end{tabular}

\begin{tabular}{l|l}
\hline DATE & 07 July 2010 \\
\hline PAGES & 1 \\
\hline SUBJECT & Ethics Approval: No 17832 \\
\hline
\end{tabular}

Thank you for your applications for ethical approval, which have now been considered by the Standing Committee of the Human Ethics Committee.

Your applications have been approved from the above date and this approval continues until 15 May 2013. If your data collection is not completed by this date you should apply to the Human Ethics Committee for an extension to this approval. 
Best wishes with the research.

Allison Kirkman

Convener

216 | Environmental democracy - accessing the Hurunui River 


\subsection{Appendix B - Information and consent forms}

\section{Information Sheet for Interview Participants}

Researcher: Amanda Thomas

School of Geography, Environment and Earth Sciences

Victoria University of Wellington

thomasaman@myvuw.ac.nz

Thank you for your interest in taking part in this research. Please read the information sheet before deciding whether or not to participate.

This research is being conducted to contribute to a PhD thesis in human geography. My thesis is about the nature and origins of the disagreements over water use in the Hurunui region and how the Hurunui-Waiau Zone Committee attempts to resolve it. My research focuses particularly on concerned stakeholders and how and why they have become engaged in the issue. I will be interviewing Zone Committee members as well as stakeholders in the use of the Hurunui River. Victoria University of Wellington requires that ethics approval be obtained for research involving human participants.

\section{Interview Format}

This interview will take approximately 60 minutes of your time and will be audio recorded. It is based on a semi-structured format so the exact nature of the questions has not been determined in advance but will depend on the way that the interview develops. Should the line of questioning progress in a way that makes you uncomfortable you can decline to answer any question(s).

\section{Participation}

Your participation is completely voluntary and you can leave the interview at any time and retract any statements made before 31 July 2012 without any disadvantage to yourself. All information gathered is confidential and will only be seen by myself and my supervisor, $\mathrm{Dr}$ Sophie Bond.

On the attached consent form, you are given the option of using your real name, an organisation's name, or a code name to maintain anonymity (for instance, Participant 
One). Because of the nature of the case, anyone who is very familiar with it may connect statements to particular groups or stakeholders. However, please be assured that should you use anonymity every effort will be made to make sure you cannot be easily identified.

\section{Data Use and Storage}

The data collected will be securely stored in such a way that only myself and my supervisor will be able to gain access to it. At the end of the project any personal information will be destroyed immediately, except that on which published results rely. These data will be stored securely for a period of five years.

The completed thesis will be submitted for marking to the School of Geography, Environment and Earth Sciences and deposited in the University library. It is intended that one or more articles will be submitted to scholarly journals and that the research may form the basis of conference presentations. You may receive a final report with my findings if you wish.

This research has been approved by the Human Ethics Committee at Victoria University of Wellington.

If you have any further questions at any time, please contact me on 0273075339 or thomasaman@myvuw.ac.nz. Alternatively my supervisor, Dr Sophie Bond, can be contacted on 044635217 or Sophie.Bond@vuw.ac.nz.

Thank you for considering taking part.

Amanda Thomas 


\section{Consent Form}

I have read and understood the information sheet and I understand that I can request more information at any stage

I am aware that participation is purely voluntary and I can withdraw at any time, refuse to answer any questions, or retract any statements before 31 July 2012 without disadvantage

I consent to my real name being used in publications

If no, I would like to be identified using: (please circle one)

The name of an organisation (please identify)

A code name (please identify)

Other: (please identify)

I understand that the information I give will not be used for any purpose other than those listed below and in the information sheet without my consent

I understand I will have the chance to check the transcripts prior to publication and make any comments

I would like to receive a final report of the findings at the conclusion of the research

\section{$\mathbf{Y} / \mathbf{N}$}

If yes, my address is: 
And my email address is:

I, . consent to being interviewed and audio recorded by Amanda Thomas for the purposes of completing a PhD thesis, producing one or more journal articles and presentations at conferences.

Signed

Date 


\subsection{Appendix C - Interview Schedules}

\section{First Semi-Structured Interview Schedule for Committee Members}

1. What's your background?

2. How would you describe your interest in the Hurunui-Waiau catchment area?

3. What motivated you to become involved in water management? How did you become involved in the Zone Committee?

4. Who do you see yourself as responsible to? What do you see as your responsibilities?

5. What do you see as the main task of the Zone Committee?

6. How would you describe the Hurunui-Waiau "community"?

7. Tell me about the Hurunui River use debate. Who is involved? How long has it been going on?

8. How would you describe your understanding of the positions of various stakeholders in the conflict over water storage proposals for the Hurunui River?

9. What has stopped it from being resolved?

10. What's your position on the issue? Why? On a personal level, how do you feel about it?

11. What do you anticipate the Committee will achieve? What do you hope it will achieve?

12. What do you think the biggest constraint to developing a Zone Implementation Programme will be?

13. How do you think members' opinions of how Hurunui River water should be used will influence Committee progress? 


\section{Second Semi-Structured Interview Schedule for Committee Members}

1. Tell me about some of the successes of the Zone Committee.

2. Tell me about some of the disappointments or failures of the Zone Committee.

3. Tell me about the water quality debate.

4. How valuable do you think rūnanga representation was on the Committee?

5. How well has collaboration and consensus building worked in practice?

6. Tell me about something you have learned through your involvement with the Zone Committee.

7. Do you think any perspectives about Hurunui river management weren't heard, or weren't taken seriously enough?

8. What did you think of the time pressures the Committee was under?

9. Who do you think should be involved in water management?

10. Tell me about a time when you've been in, on, or around the Hurunui River, or another river.

a. Describe the river to me

b. How did you feel when you were there?

11. Do you think there was enough accurate information provided to the public so that they could access and contribute to HWZC meetings?

12. What do you think of media representations of debates about Hurunui River use?

13. What has been the most important result of the Zone Committee process?

14. Why do you care about what happens to the Hurunui River? 


\section{Semi-Structured Interview Schedule for Members of Public}

1. Tell me about yourself and your background.

2. How would you describe your interest in the Hurunui-Waiau catchment area?

3. How much do you know about what's going on with the management of the Hurunui River?

4. How do your views fit with media representations of debates about Hurunui River use?

5. What has motivated you to become involved in/stay outside water politics?

6. Tell me about a time when you've been in, on, or around the Hurunui River, or another river.

a. Describe the river to me

b. How did you feel when you were there?

7. Have you had any interactions with the Hurunui-Waiau Zone Committee? Why or why not?

8. From what you know about the HWZC's work, do you think that they have included all values and perspectives?

9. Do you have any reflections on the Zone Implementation Programme that HWZC developed?

10. Do you think there was there enough information available to the public about HWZC meetings?

11. How important is it for local iwi to be involved in managing the Hurunui River? Do you think Ngāi Tahu representation on HWZC was valuable?

12. Have you been involved with any other groups that are involved in managing the Hurunui River? 


\section{Short Interview with Members of Public}

1. Tell me about yourself.

Location:

$M / F$

Ethnicity:

Approx age range:

Lives in:

For years

2. How much do you know about what's going on with the management of the Hurunui River? (Question further about ZIP, inclusion/exclusion of perspectives) 
3. Tell me about a time when you've been in, on, or around the Hurunui River, or another river.

a. Describe the river to me

b. How did you feel when you were there?

4. Who do you think should be involved in managing the Hurunui River?

5. How important is it for local iwi to be involved in managing the Hurunui River? [Do you think Ngāi Tahu representation on HWZC was valuable?]

6. Have you been part of any groups that are involved in managing the Hurunui River? 


\section{Reference list}

Adey, P. (2009). Facing airport security: affect, biopolitics, and the preemptive securitisation of the mobile body. Environment and Planning D, 27, 274-295.

Agamben, G. (2005). State of Exception (K. Attell, Trans.). Chicago; London: The University of Chicago Press.

Agarwal, B. (2001). Participatory exclusions, community forestry, and gender: an analysis for South Asia and a conceptual framework. World Development, 29(10), 1623-1648.

Agrawal, A. (2005). Environmentality: Technologies of Government and the Making of Subjects. Durham; London: Duke University Press.

Agrawal, A., \& Gibson, C. C. (1999). Enchantment and disenchantment - the role of community in natural resource conservation. World Development, 27(4), 629-349.

Agrawal, A., \& Ribot, J. C. (1999). Accountability in decentralization: a framework with South Asian and African cases. Journal of Developing Areas, 33(Summer), 473-502.

Allen, J. (2004). Whereabouts of power: politics, government and space. Geografiska Annaler Series B, Human Geography, 86(1), 19-32.

Allen, W., Fenemor, A., Kilvington, M., Harmsworth, G., Young, R. G., Deans, N., et al. (2011). Building collaboration and learning in integrated catchment management: the importance of social process and multiple engagement approaches. New Zealand Journal of Marine and Freshwater Research, 45(3), 525-539.

Amin, A., \& Thrift, N. (2005). What's left? Just the future. Antipode, 37(2), 220-238.

Anderson, J., Adey, P., \& Bevan, P. (2010). Positioning place: polylogic approaches to research methodology. Qualitative Research, 10(5), 589-604.

Anderson, K. (1995). Culture and nature at the Adelaide Zoo: at the frontiers of 'human' geography. Transactions of the Institute of British Geographers, 20(3), 275-294. 
Apostolopoulo, E., \& Pantis, J. D. (2010). Development plans versus conservation: explanation of emergent conflicts and state political handling. Environment and Planning A, 42(4), 982-1000.

Argent, N. (2008). Perceived density, social interaction and morale in New South Wales rural communities. Journal of Rural Studies, 24(3), 245-261.

Austin, W. J. (2008). Relational ethics. In L. M. Given (Ed.), The SAGE Encyclopedia of Qualitative Research (pp. 749-750). Los Angeles: Sage.

Ayre, M., \& Mackenzie, J. (2012). "Unwritten, unsaid, just known": the role of Indigenous knowledge(s) in water planning in Australia. Local Environment: The International Journal of Justice and Sustainability, 18(7), 753-768.

Bakker, K. (2002). From state to market? Water mercantilizacion in Spain. Environment and Planning A, 34(5), 767-790.

Bakker, K. (2003). A political ecology of water privatization. Studies in Political Economy(70), 35-58.

Bakker, K. (2005). Neoliberalizing nature? Market environmentalism in water supply in England and Wales. Annals of the Association of American Geographers, 95(3), 542-565.

Bakker, K. (2007). The "commons" versus the "commodity": alter-globalization, antiprivatization and the human right to water in the global south. Antipode, 39(3), 430 455.

Bakker, K. (2010). The limits of 'neoliberal natures': debating green neoliberalism. Progress in Human Geography, 34(6), 715-735.

Bakker, K., \& Bridge, G. (2006). Material worlds? Resource geographies and the 'matter of nature'. Progress in Human Geography, 30(5), 5-27.

Baldwin, A., Cameron, L., \& Kobayashi, A. (2011). Where is the Great White North? Spatializing history, historicizing whiteness. In A. Baldwin, L. Cameron \& A. Kobayashi (Eds.), Rethinking the Great White North: Race, Nature, and the Historical Geographies of Whiteness in Canada (pp. 1-15). Vancouver; Toronto: UBC Press.

Barad, K. (2003). Posthumanist performativity: toward an understanding of how matter comes to matter. Gender and Science, 28(3), 801-831. 
Bargh, M. (2007). Māori development and neoliberalism. In M. Bargh (Ed.), Resistance: An Indigenous Response to Neoliberalism (pp. 25-44). Wellington: Huia.

Bargh, M. (2012). Rethinking and re-shaping indigenous economies: Māori geothermal energy enterprises. Journal of Enterprising Communities: People and Places in the Global Economy, 6(3), 271-283.

Bargh, M., \& Otter, J. (2009). Progressive spaces of neoliberalism in Aotearoa: a genealogy and critique. Asia Pacific Viewpoint, 50(2), 154-165.

Barnes, J. (2013). Who is a water user? The politics of gender in Egypt's water user associations. In L. M. Harris, J. A. Goldin \& C. Sneddon (Eds.), Contemporary Water Governance in the Global South: Scarcity, Marketization and Participation (pp. 185198). Abingdon, UK; New York, USA;: Routledge.

Barnes, T. J., \& Duncan, J. S. (1992). Introduction: writing worlds. In T. J. Barnes \& J. S. Duncan (Eds.), Writing Worlds: Discourse, Text and Metaphor in the Representation of Landscape (pp. 1-17). London; New York: Routledge.

Barnett, C. (2005). Critical review: The consolations of 'neoliberalism'. Geoforum, 39(1), 7-12.

Barnett, J., \& Pauling, J. (2005). The environmental effects of New Zealand's free-market reforms. Environment, Development and Sustainability, 7(2), 271-289.

Basher, R. (1998). The 1997/98 El Nino event: impacts, responses and outlook for New Zealand (Report 73). Wellington: New Zealand Ministry of Research Science and Technology

Bawaka Country, Suchet-Pearson, S., Wright, S., Lloyd, K., \& Burarrwanga, L. (2013). Caring as Country: towards an ontology of co-becoming in natural resource management. Asia Pacific Viewpoint, 54(2), 185-197.

BBC Hardtalk. (2011). New Zealand PM John Key: 'we are 100\% pure'. Retrieved from http://news.bbc.co.uk/2/hi/programmes/hardtalk/9480610.stm

Bear, C., \& Eden, S. (2011). Thinking like a fish? Engaging with nonhuman difference through recreational angling. Environment and Planning D, 29(2), 336-352.

Beck, U. (1996). The Reinvention of Politics: Rethinking Modernity in the Global Social Order (M. Ritter, Trans.). Cambridge, Massachusetts: Polity Press.

Beeson, M. (2007). Competing capitalisms and neoliberalisms: the dynamics of, and limits to, economic reform in the Asia-Pacific. In K. England \& K. Ward (Eds.), Neoliberalization: States, Networks, Peoples (pp. 28-47). Malden, MA: Blackwell Publishing. 
Beisel, U. (2010). Jumping hurdles with mosquitoes? Environment and Planning D, 28(1), 4649.

Benhabib, S. (1996a). Toward a deliberative model of democratic legitimacy. In S. Benhabib (Ed.), Democracy and Difference: Contesting the Boundaries of the Political (pp. 67-94). New Jersey: Princeton University Press.

Benhabib, S. (Ed.). (1996b). Democracy and Difference: Contesting the Boundaries of the Political. New Jersey: Princeton University Press

Bennett, A. (2013). Govt opens forest to prospectors. Retrieved from http://www.nzherald.co.nz/nz/news/article.cfm?c id=1\&objectid=11115354

Bennett, J. (2004). The force of things: steps toward an ecology of matter. Political Theory, $32(3), 347-372$.

Bennett, J. (2010). Vibrant Matter: a Political Ecology of Things. Durham; London: Duke University Press.

Bestwick, J. (2012). Report for Environment Canterbury - review of selection, replacement and terms of reference for the CWMS zone and regional committees: The Project Office.

Biersack, A., \& Greenberg, J. B. (Eds.). (2006). Reimagining Political Ecology. Durham; London: Duke University Press

Bishop, R. (1996). Collaborative Research Stories: Whakawhanaungatanga. Palmerston North: Dunmore Press.

Bishop, R. (2008). Te kotahitanga: kaupapa Māori in mainstream classrooms. In N. K. Denzin, Y. S. Lincoln \& L. T. Smith (Eds.), Handbook of Critical and Indigenous Methodologies (pp. 439-458). Thousand Oaks: SAGE.

Blaikie, P. (2008). Epilogue: Towards a future for political ecology that works. Geoforum, 39(2), $765-772$.

Blaikie, P., \& Brookfield, H. (1987). Land Degradation and Society. London, New York: Methuen.

Bond, S. (2011a). Being in myth and community: resistance, lived existence, and democracy in a north England mill town. Environment and Planning D, 29(5), 780-802. 
Bond, S. (2011b). Negotiating a 'democratic ethos': moving beyond the agonistic communicative divide. Planning Theory, 10(2), 161-186.

Bond, S., \& Thompson-Fawcett, M. (2007). Public participation and new urbanism: a conflicting agenda? Planning Theory and Practice, 8(4), 449-472.

Bondi, L. (2007). The place of emotions in research: from partitioning emotion and reason to the emotional dynamics of research relationships. In J. Davidson, L. Bondi \& M. Smith (Eds.), Emotional Geographies (pp. 231-246). Aldershot, England; Burlington, USA: Ashgate.

Bondi, L. (2009). Teaching reflexivity: undoing or reinscribing habits of gender? Journal of Geography in Higher Education, 33(3), 327-337.

Boston, J., St. John, S., \& Dalziel, P. (Eds.). (1999). Redesigning the Welfare State in New Zealand: Problems, Policies, Prospects. Auckland: Oxford University Press

Bradshaw, M., \& Stratford, E. (2010). Qualitative research design and rigour. In I. Hay (Ed.), Qualitative Research Methods in Human Geography (3rd ed., pp. 69-80). Melbourne: Oxford University Press.

Braun, B. (2004). Modalities of posthumanism. Environment and Planning A, 36(8), 1352-1355.

Braun, B., \& Wainwright, J. (2001). Nature, poststructuralism, and politics. In N. Castree \& B. Braun (Eds.), Social Nature: Theory, Practice, and Politics (pp. 41-63). Malden, MA: Blackwell.

Braun, B., \& Whatmore, S. J. (2010). The stuff of politics: an introduction. In B. Braun \& S. J. Whatmore (Eds.), Political Matter: Technoscience, Democracy, and Public Life (pp. ixxl). Minneapolis; London: University of Minnesota Press.

Brenner, N., \& Theodore, N. (2007). Neoliberalism and the regulation of "environment". In N. Heynen, McCarthy, J., Prudham, S., and Robbins, P. (Ed.), Neoliberal Environments: False Promises and Unnatural Consequences (pp. 153-159). London; New York: Routledge.

Bridge, G., \& Perreault, T. (2009). Environmental governance: a review and critique. In N. Castree, D. Demeritt, D. Liverman \& B. Rhoads (Eds.), A Companion to Environmental Geography (pp. 475-497). Oxford: Blackwell.

Britton, S., Le Heron, R., \& Pawson, E. (Eds.). (1992). Changing Places in New Zealand: a Geography of Restructuring. Christchurch: New Zealand Geographical Society 
Broderick, K. (2005). Communities in catchments: implications for natural resource management. Geographical Research, 43(3), 286-296.

Brosius, J. P., Tsing, A. L., \& Zerner, C. (1998). Representing communities: histories and politics of community-based natural resource management. Society and Natural Resources: An International Journal, 11(2), 157-168.

Brower, A. (2010a, 25 August). ECan Act staggering use of legislative power. Retrieved from http://www.stuff.co.nz/the-press/opinion/3729741/ECan-Act-staggering-use-oflegislative-power

Brower, A. (2010b). Legislative note: Environment Canterbury (Temporary Commissioners and Improved Water Management) Act 2010. NZ Journal of Environmental Law, 14

Brown, B. (2007). I Thought it Was Just Me (But it Isn't): Telling the Truth About Perfectionism, Inadequacy and Power. New York: Penguin Group.

Browning, C. (2011). Mike Joy answers the PM, with hard facts. Retrieved from http://pundit.co.nz/content/mike-joy-answers-the-pm-with-hard-facts

Brownlow, A. (2011). Between rights and responsibilities: insurgent performance in an invisible landscape. Environment and Planning A, 43(5), 1268-1286.

Budds, J. (2009). Contested H2O: science, policy and and politics in water resources management in Chile. Geoforum, 40(3), 418-430.

Bulkeley, H., Watson, M., \& Hudson, R. (2007). Modes of governing municipal waste. Environment and Planning A, 39(11), 2733-2753.

Burke, K. (2013). How ECan fell to the irrigators. Retrieved from http://www.stuff.co.nz/thepress/opinion/perspective/8205626/How-ECan-fell-to-the-irrigators

Butler, J. (1990). Gender Trouble: Feminism and the Subversion of Identity. New York: Routledge.

Butler, J. (1993). Bodies that Matter: On the Discursive Limits of "Sex". London: Routledge.

Butler, J. (2006). Precarious Life: the Powers of Mourning and Violence. London: Verso.

Cahill, A. (2008). Power over, power to, power with: shifting perceptions of power for local economic development in the Philippines. Asia Pacific Viewpoint, 49(3), 294-304. 
Cahill, C., Sultana, F., \& Pain, R. (2007). Participatory ethics: politics, practices, institutions. ACME, 6(3), 304-318.

Cairns, L. (2012). ECan commissioners staying until 2016. Retrieved from http://www.stuff.co.nz/national/politics/7632162/ECan-commissioners-staying-until$\underline{2016}$

Cairns, R., Sallu, S. M., \& Goodman, S. (forthcoming). Questioning calls to consensus in conservation: a Q study of conservation discourses on Galápagos. Environmental Conservation 10.1017/S0376892913000131

Callon, M. (1986). Some elements of a sociology of translation: domestication of the scallops and fishermen of St Brieuc Bay. In J. Law (Ed.), Power, Action Belief: A New Sociology of Knowledge? (pp. 19-34). London: Routledge.

Callon, M., \& Law, J. (1995). Agency and the hybrid collectif. South Atlantic Quarterly, 94(2), 481-507.

Cameron, E. (2011). Copper stories: imaginative geographies and material orderings of the central Canadian Arctic. In A. Baldwin, L. Cameron \& A. Kobayashi (Eds.), Rethinking the Great White North: Race, Nature, and the Historical Geographies of Whiteness in Canada (pp. 169-190). Vancouver; Toronto: UBC Press.

Cameron, J., \& Gibson-Graham, J. K. (2003). Feminising the economy: metaphors, strategies, politics. Gender, Place and Culture, 10(2), 145-157.

Canterbury Mayoral Forum. (2009). Canterbury water management strategy. Retrieved from www.canterburywater.org.nz

Canterbury Water. (2010). Canterbury Water Management Strategy: Strategic Framework November 2009 (targets updated July 2010). Retrieved from http://ecan.govt.nz/publications/Plans/cw-canterbury-water-wanagement-strategy05-11-09.pdf

Castree, N. (2001). Socializing nature: theory, practice, and politics. In N. Castree \& B. Braun (Eds.), Social Nature: Theory, Practice, and Politics (pp. 1-21). Malden, MA: Blackwell.

Castree, N. (2002). False antithesis? Marxism, nature and actor-networks. Antipode, 34(1), 111-146.

Castree, N. (2003). Environmental issues: relational ontologies and hybrid politics. Progress in Human Geography, 27(2), 203-211. 
Castree, N. (2008). Neoliberalising nature: processes, effects, and evaluations. Environment and Planning A, 40(1), 153-173.

Castree, N. (2009). Neoliberalism, democracy and the environment: false dawns and achievable tomorrows for a new British Left. Radical Politics Today, May. Retrieved from http://www.spaceofdemocracy.org/word\%20docs\%20linked\%20to/Uploaded\%20May \%202009/Castree/Radical\%20Politics\%20Today,\%20Noel\%20Castree,\%20May\%20200 9.pdf

Castree, N. (2010). Neoliberalism and the biophysical environment 2: theorising the neoliberalisation of nature. Geography Compass, 4(12), 1734-1746.

Castree, N. (2011a). Nature Part I. In J. A. Agnew \& J. S. Duncan (Eds.), The Wiley-Blackwell Companion to Human Geography (pp. 179-196). Chichester: Wiley- Blackwell.

Castree, N. (2011b). Neoliberalism and the biophysical environment 3: putting theory into practice. Geography Compass, 5(1), 35-49.

Castree, N., Chatterton, P., Heynen, N., Larner, W., \& Wright, M. W. (2010). The point is to change it. Antipode, 41(s1), 1-9.

Caygill, D. (2011). Consensus for Hurunui and Waiau Rivers. Retrieved from http://www.stuff.co.nz/the-press/opinion/perspective/5859347/Consensus-forHurunui-and-Waiau-rivers

Celata, F., \& Sanna, V. S. (2012). The post-political ecology of protected areas: nature, social justice and political conflicts in the Galápagos Islands. Local Environment: The International Journal of Justice and Sustainability, 17(9), 977-990.

Central Plains Water Limited. (2013). Benefits to our region. Retrieved from http://www.cpwl.co.nz/economic-benefits

Charmaz, K. (2011). Grounded theory methods in social justice research. In N. K. Denzin \& Y. S. Lincoln (Eds.), The SAGE Handbook of Qualitative Research (4th ed., pp. 359-380). Thousand Oaks: SAGE.

Chatterton, P., Featherstone, D., \& Routledge, P. (2012). Articulating climate justice in Copenhagen: antagonism, the commons, and solidarity. Antipode, 45(3), 602-620.

Clark, D. A., \& Slocombe, D. S. (2011). Grizzly bear conservation in the Foothills Model Forest: appraisal of a collaborative ecosystem management effort. Policy Sciences, 44(1), 1-11. 
Clark, H. (2010). Environment Canterbury: new commissioners take over. Retrieved from http://www.3news.co.nz/Environment-Canterbury-New-commissioners-takeover/tabid/419/articlelD/152340/Default.aspx

Clarke, J. (2010). After neo-liberalism? Markets, states and the reinvention of public welfare. Cultural Studies, 24(3), 375-394.

Cloke, P., \& Little, J. (1997a). Conclusion: marginality and rural others. In P. Cloke \& J. Little (Eds.), Contested Countryside Cultures: Otherness, Marginalisation and Rurality (pp. 272-285). London; New York: Routledge.

Cloke, P., \& Little, J. (1997b). Introduction: other countrysides? In P. Cloke \& J. Little (Eds.), Contested Countryside Cultures: Otherness, Marginalisation and Rurality (pp. 1-18). London; New York: Routledge.

Cloke, P., Milbourne, P., \& Widdowfield, R. (2000). Partnership and policy networks in rural local governance: homelessness in Taunton. Public Administration, 78(1), 111-133.

Cloke, P., \& Perkins, H. C. (2005). Cetacean performance and tourism in Kaikoura, New Zealand. Environment and Planning D, 23(6), 903-924.

Cocklin, C., \& Blunden, G. (1998). Sustainability, water resources and regulation. Geoforum, 29(1), 51-68.

Cocklin, C., \& Furuseth, O. J. (1994). Geographical dimensions of environmental restructuring in New Zealand. The Professional Geographer, 46(4), 459-467.

Cook, I. (2005). Participant observation. In R. Flowerdew \& D. Martin (Eds.), Methods in Human Geography: A Guide for Students Doing a Research Project (2nd ed., pp. 167188). Harlow, England: Pearson Education.

Coombes, B. (2003). The historicity of institutional trust and the alienation of Maori land for catchment control at Mangatu, New Zealand. Environment and History, 9(3), 333-359.

Coombes, B. (2007a). Defending community? Indigeneity, self-determination and institutional ambivalence in the restoration of Lake Whakaki. Geoforum, 38(1), 60-72.

Coombes, B. (2007b). Postcolonial conservation and kiekie harvests at Morere New Zealand abstracting indigenous knowledge from indigenous polities. Geographical Research, 45(2), 186-193. 
Coombes, B. (2013). Indigenism, public intellectuals, and the forever opposed - or, the making of a "hori academic". In D. M. Mertens, F. Cram \& B. Chilisa (Eds.), Indigenous

Pathways into Social Research: Voices of a New Generation (pp. 71-88). Walnut Creek, California: Left Coast Press.

Coombes, B., Gombay, N., Johnson, J. T., \& Shaw, W. S. (2011). The challenges of and from indigenous geographies. In V. J. Del Casino, M. E. Thomas, P. Cloke \& R. Panelli (Eds.), A Companion to Social Geography (pp. 472-489). Oxford: Blackwell.

Coombes, B., Johnson, J. T., \& Howitt, R. (2012). Indigenous geographies I: mere resource conflicts? The complexities in Indigenous land and environmental claims. Progress in Human Geography, 36(6), 810-821.

Cox, M., Arnold, G., \& Villamayor Tomás, S. (2010). A review of design principles for community-based natural resource management. Ecology and Society, 15(4), 38.

Crang, M. (2005). Analysing qualitative materials. In R. Flowerdew \& D. Martin (Eds.), Methods in Human Geography: A Guide for Students Doing a Research Project (pp. 218-232). Harlow, England: Pearson Education.

Creech, W., Jenkins, M., Hill, G., \& Low, M. (2010). Investigation of the performance of Environment Canterbury under the Resource Management Act and Local Government Act. Wellington: Ministry for the Environment

Cronon, W. (1996). The trouble with wilderness: or, getting back to the wrong nature. Environmental History, 1(1), 7-28.

Crutzen, P. (2002). Geology of mankind. Nature, 415(3), 23.

Cumberland, K. B. (1941). A century's change: natural to cultural vegetation in New Zealand. The Geographical Review, 31(4), 529-554.

Cunningham, C. (2000). A framework for addressing Māori knowledge in research, science and technology. Pacific Health Dialog, 7(1), 62-69.

Cupples, J. (2002). The field as a landscape of desire: sex and sexuality in geographical fieldwork. Area, 34(4), 382-390.

Cupples, J., \& Kindon, S. (2003). Far from being "home alone": the dynamics of accompanied fieldwork. Singapore Journal of Tropical Geography, 24(2), 211-228.

Cupples, J., \& Pawson, E. (2012). Giving an account of oneself: the PBRF and the neoliberal university. New Zealand Geographer, 68(1), 14-23. 
Curtis, A. (2013). Irrigation 'benefits city and farm'. Retrieved from http://www.stuff.co.nz/the-press/opinion/perspective/8216073/Irrigation-benefitscity-and-farm

Dahmann, N., Featherstone, D., Larner, W., Swyngedouw, E., Dufaux, F., Lehman-Frisch, S., et al. (2012). Review forum: Reading Mustafa Dikeç's Badlands of the Republic: Space, Politics and Urban Policy. Political Geography, 31(5), 324-333.

Davidson, J., Bondi, L., \& Smith, M. (Eds.). (2007). Emotional Geographies. Aldershot, England; Burlington, USA: Ashgate

Davies, G., \& Dwyer, C. (2007). Qualitative methods: are you enchanted or are you alienated? Progress in Human Geography, 31(2), 257-266.

Davison, I. (2013). Deep seas law 'a sledgehammer'. Retrieved from http://www.nzherald.co.nz/politics/news/article.cfm?c id=280\&objectid=10876284

Dean, M. (2010, 2-3 December). A response to the questions what is neoliberalism?, etcetera. Paper presented at the Contesting neoliberalism and its future workshop, University of Sydney. http://sydney.edu.au/arts/political economy/about/events/contesting neoliberalism workshop.shtml.

Dearnaley, M. (2001). Milk versus water: a clash of cultures. Retrieved from http://www.nzherald.co.nz/nz/news/article.cfm?c id=1\&objectid=194265

Dempsey, J., Gould, K., \& Sundberg, J. (2011). Changing land tenure, defining subjects: neoliberalism and property regimes on native reserves. In A. Baldwin, L. Cameron \& A. Kobayashi (Eds.), Rethinking the Great White North: Race, Nature, and the Historical Geographies of Whiteness in Canada (pp. 233-255). Vancouver; Toronto: UBC Press.

Dhaliwal, A. (1996). Can the subaltern vote? Radical democracy, discourses of representation and rights, and the question of race. In Trend. D (Ed.), Radical Democracy (pp. 42-61). London: Routledge.

Diane Revoluta. (2012). Something is rotten in the state of New Zealand. Retrieved from http://dianerevoluta.tumblr.com/post/22417160324/something-is-rotten-in-thestate-of-new-zealand

Dietz, T., Ostrom, E., \& Stern, P. C. (2003). The struggle to govern the commons. Science, 302(5652), 1907-1912. 
Dikeç, M. (2012). Space as a mode of political thinking. Geoforum, 43(4), 669-676.

Diprose, G., Thomas, A. C., \& Rushton, R. (2013). Desiring more: complicating understandings of sexuality in research processes. Area, 45(3), 292-298.

Dressler, W., Büscher, B., Schoon, M., Brockington, D., Hayes, T., Kull, C. A., et al. (2010). From hope to crisis and back again? A critical history of the global CBNRM narrative. Environmental Conservation, 37(1), 5-15.

Dryzek, J. S. (2001). Legitimacy and economy in deliberative democracy. Political Theory, 29(5), 651-669.

Durie, M. (1996, 1 February). Characteristics of Māori health research. Paper presented at the Hui Whakapiripiri, Hongoeka Marae.

Durie, M. (1998). Te Mana Te Kawanatanga: the Politics of Maori Self-Determination. Auckland; New York: Oxford University Press.

Dymond, J. R., Ausseil, A.-G. E., Parfitt, R. L., Herzig, A., \& McDowell, R. W. (2013). Nitrate and phosphorous leaching in New Zealand: a national perspective. New Zealand Journal of Agricultural Research, 56(1), 49-59.

Eder, D., \& Whitehouse, I. (2013). Collaborative water management delivers local solutions in North Canterbury. Retrieved from http://sciblogs.co.nz/waiology/2013/04/04/collaborative-water-managementdelivers-local-solutions-in-north-canterbury/

Ekers, M., \& Loftus, A. (2008). The power of water: developing dialogues between Foucault and Gramsci. Environment and Planning D, 26(4), 698-718.

Elmhirst, R. (2011). Introducing new feminist political ecologies. Geoforum, 42(2), 129-132.

Elwood, S. (2007). Negotiating participatory ethics in the midst of institutional ethics. ACME, 6(3), 329-338.

Elwood, S. A., \& Martin, D. G. (2000). "Placing" interviews: location and scales of power in qualitative research. The Professional Geographer, 52(4), 649-657.

England, K. (1994). Getting personal: reflexivity, positionality, and feminist research. The Professional Geographer, 46(1), 80-89. 
England, K., \& Ward, K. (2007). Conclusion: reflections on neoliberalizations. In K. England \& K. Ward (Eds.), Neoliberalization: States, Networks, Peoples (pp. 248-262). Malden, MA: Blackwell Publishing.

Environment Canterbury. (2009). Mayors' letter to Minister out of left field. Retrieved from http://www.scoop.co.nz/stories/AK0909/S00380/mayors-letter-to-minister-out-ofleft-field.htm

Environment Canterbury. (2010). Canterbury Water Management Strategy zone committees roll out progresses. Retrieved from http://ecan.govt.nz/news-andnotices/news/pages/canterbury-water-management-strategy-zone-committees-rollout-progresses.aspx

Environment Canterbury. (2011). Proposed Hurunui and Waiau River Regional Plan. Retrieved from http://ecan.govt.nz/publications/Plans/hurunui-waiau-regional-plan.pdf

Environment Canterbury. (2013a). Environment Canterbury accepts proposed HWRRP recommendations. Retrieved from http://ecan.govt.nz/news-andnotices/news/pages/ec-proposed-hwrrp-recommendations.aspx

Environment Canterbury. (2013b). Hearing commissioner recommendation to the Proposed Hurunui and Waiau River Regional Plan and Proposed Plan Change 3 to the Canterbury Natural Resources Regional Plan. Retrieved from http://ecan.govt.nz/publications/Council/council-agenda-180413-hwp-commissionersrecommendation.pdf

Featherstone, D. (2008). Resistance, Space and Political Identities: the Making of CounterGlobal Networks. Chichester: Wiley-Blackwell.

Featherstone, D. (2013). The contested politics of climate change and the crisis of neoliberalism. ACME, 12(1), 44-64.

Featherstone, D., \& Korf, B. (2012). Space, contestation and the political. Geoforum, 43, 663668.

Finnie, S. (2010). Water protest attracts thousands. Retrieved from http://straightfurrow.farmonline.co.nz/news/nationalrural/agribusiness-andgeneral/general/water-protest-attracts-thousands/1857610.aspx?storypage $=0$

Flyvbjerg, B. (1998). Rationality and Power: Democracy in Practice. Chicago: University of Chicago Press. 
Fontana, A., \& Bertani, M. (2003). Situating the lectures. In M. Foucault (Ed.), Society Must be Defended: Lectures at the Collége de France, 1975-76 (pp. 273-293). New York: Picador.

Forest and Bird. (2011). Wild rivers. Retrieved from http://www.forestandbird.org.nz/savingour-environment/freshwater-/wild-rivers

Forsyth, T. (2003). Critical Political Ecology: the Politics of Environmental Science. New York: Routledge.

Foucault, M. (1990). The History of Sexuality (R. Hurley, Trans.). London: Penguin.

Frantz, K., \& Howitt, R. (2012). Geography for and with indigenous peoples: indigenous geographies as challenge and invitation. GeoJournal, 77(6), 727-731.

Fukuyama, F. (1992). The End of History and the Last Man. London: Penguin.

Ghose, R. (2005). The complexities of citizen participation through collaborative governance. Space and Polity, 9(1), 61-75.

Gibbs, L. M. (2009). Water places: cultural, social and more-than-human geographies of nature. Scottish Geographical Journal, 125(3-4), 361-369.

Gibbs, L. M. (2010). "A beautiful soaking rain": environmental value and water beyond Eurocentrism. Environment and Planning D: Society and Space, 28(2), 363-378.

Gibson-Graham, J. K. (1994). 'Stuffed if I know!': reflections on post-modernist feminist social research. Gender, Place and Culture, 1(2), 205-224.

Gibson-Graham, J. K. (2000). Poststructural interventions. In E. Sheppard \& T. J. Barnes (Eds.), A Companion to Economic Geography (pp. 95-110). Oxford: Malden, Massachusetts: Blackwell.

Gibson-Graham, J. K. (2006). A Postcapitalist Politics. Minneapolis; London: University of Minnesota Press.

Gibson-Graham, J. K. (2008). Diverse economies: performative practices for 'other worlds'. Progress in Human Geography, 32(5), 613-632.

Gibson-Graham, J. K., Cameron, J., \& Healy, S. (2013). Take Back the Economy: An Ethical Guide for Transforming Our Communities. Minneapolis: University of Minnesota. 
Gibson-Graham, J. K., \& Roelvink, G. (2009). An economic ethics for the Anthropocene. Antipode, 41(s1), 320-346.

Giddens, A. (1994). Beyond Left and Right: the Future of Radical Politics. Stanford: Stanford University Press.

Giddens, A. (1998). The Third Way: the Renewal of Social Democracy. Cambridge, MA: Polity.

Ginn, F. (2008). Extension, subversion, containment: eco-nationalism and (post)colonial nature in Aotearoa New Zealand. Transactions - Institute of British Geographers, 33(3), 335353.

Glaser, B. G., \& Strauss, A. L. (1967). The Discovery of Grounded Theory: Strategies for Qualitative Research. Chicago: Aldine.

Goldin, J. A. (2013). The participatory paradigm: anathema, praise and confusion. In L. M. Harris, J. A. Goldin \& C. Sneddon (Eds.), Contemporary Water Governance in the Global South: Scarcity, Marketization and Participation (pp. 179-184). Abingdon, UK; New York, USA;: Routledge.

Goodall, A. (2005). Tai timu, tai pari ... the ever-changing tide of Indigenous rights in Aotearoa New Zealand. In G. Cant, A. Goodall \& J. Inns (Eds.), Discourses and Silences: Indigenous Peoples, Risks and Resistance (pp. 185-198). Christchurch: Department of Geography, University of Canterbury.

Gorman, P. (2009). Combative approach unpopular. Retrieved from http://www.stuff.co.nz/the-press/news/2364863/Combative-approach-unpopular

Gorman, P. (2010). Officials opposed ECan changes. Retrieved from http://www.stuff.co.nz/the-press/news/3618491/Officials-opposed-ECan-changes

Green Party. (2011). Minister pulls teeth from clean water rules. Retrieved from http://www.scoop.co.nz/stories/PA1105/S00178/minister-pulls-teeth-from-cleanwater-rules.htm

Greenhill, M. (2010a, 13 October 2010). Ngai Tahu revokes support for order. The Press.

Greenhill, M. (2010b). Water committee appointments delayed. Retrieved from http://www.stuff.co.nz/the-press/news/3779819/Water-committee-appointmentsdelayed 
Grundy, K. J., \& Gleeson, B. J. (1996). Sustainable management and the market: the politics of planning reform in New Zealand. Land Use Policy, 13(3), 197-211.

Gunder, M. (2010). Planning as the ideology of (neoliberal) space. Planning Theory, 9(4), 298314.

Gunder, M., \& Mouat, C. (2002). Symbolic violence and victimization in planning processes: a reconniotre of the New Zealand Resource Management Act. Planning Theory, 1(2), 124-145.

Habermas, J. (1975). Legitimation Crisis (T. McCarthy, Trans.). Boston: Beacon Press.

Habermas, J. (1984). The Theory of Communicative Action. Vol 1 Reason and the Rationalization of Society. Boston, MA: Beacon Press.

Habermas, J. (1987). The Philosophical Discourse of Modernity. Cambridge: MIT Press.

Habermas, J. (1996). Three normative models of democracy. In S. Benhabib (Ed.), Democracy and Difference: Contesting the Boundaries of the Political (pp. 21-30). New Jersey: Princeton University Press.

Hajer, M. (1995). The Politics of Environmental Discourse: ecological modernisation and the policy process. Oxford: Clarendon Press.

Hajer, M. A. (2005). Coalitions, practices, and meaning in environmental politics: from acid rain to BSE. In D. Howarth \& J. Torfing (Eds.), Discourse Theory in European Politics: Identity, Policy and Governance (pp. 297-315). New York: Palgrave Macmillan.

Haraway, D. (1985). Manifesto for cyborgs: science, technology and socialist feminism in the 1980s. Socialist Review, 80, 65-108.

Haraway, D. (1994). A game of cat's cradle: science studies, feminist theory, cultural studies. Configurations, 2(1), 59-71.

Haraway, D. (2008). When Species Meet. Minneapolis; London: University of Minnesota Press.

Hardin, G. (1968). The tragedy of the Commons. Science, 162(3859), 1243-1248.

Hardin, G. (1974). Living on a lifeboat. BioScience, 24(10), 561-568. 
Harris, L. M. (2009). Gender and emergent water governance: comparative overview of neoliberalized natures and gender dimensions of privatization, devolution and marketization. Gender, Place and Culture, 16(4), 387-408.

Harris, L. M. (2011). Neo(liberal) citizens of Europe: politics, scales, and visibilities of environmental citizenship in contemporary Turkey. Citizenship Studies, 15(6-7), 837859.

Harvey, D. (2003). The New Imperialism. Oxford: Oxford University Press.

Harvey, D. (2005). A Brief History of Neoliberalism. New York: Oxford University Press.

Haughton, G., Allmendinger, P., \& Oosterlynck, S. (2013). Spaces of neoliberal experimentation: soft spaces, postpolitics, and neoliberal governmentality. Environment and Planning A, 45(1), 217-234.

Hawkins, R., \& Ojeda, D. (2011). Gender and environment: critical tradition and new challenges. Environment and Planning D, 29(2), 237-253.

Hayward, B. (2012). Canterbury's political quake. Retrieved from http://www.stuff.co.nz/thepress/opinion/perspective/6664104/Canterburys-political-quake

Head, L., \& Atchison, J. (2009). Cultural ecology: emerging human-plant geographies. Progress in Human Geography, 33(2), 236-245.

Hemmingsen, S. (2005). The re-instatement of Ngāi Tahu involvement in the coastal management of Akaroa Harbour, South Island, New Zealand. In G. Cant, A. Goodall \& J. Inns (Eds.), Discourses and Silences: Indigenous Peoples, Risks and Resistance (pp. 171183). Christchurch: Department of Geography, University of Canterbury.

Heynen, N., McCarthy, J., Prudham, S., \& Robbins, P. (2007a). Conclusion: unnatural consequences. In N. Heynen, McCarthy, J., Prudham, S., and Robbins, P. (Ed.), Neoliberal Environments: False Promises and Unnatural Consequences (pp. 287-291). London; New York: Routledge.

Heynen, N., McCarthy, J., Prudham, S., \& Robbins, P. (2007b). Introduction: false promises. In N. Heynen, McCarthy, J., Prudham, S., and Robbins, P. (Ed.), Neoliberal Environments: False Promises and Unnatural Consequences (pp. 1-21). London; New York: Routledge.

Heynen, N., \& Robbins, P. (2005). The neoliberalization of nature: governance, privatization, enclosure and valuation. Capitalism Nature Socialism, 16(1), 5-8. 
Hibbard, M., Lane, M. B., \& Rasmussen, K. (2008). The split personality of planning: Indigenous peoples and planning for land and resource management. Journal of Planning Literature, 23(2), 136-151.

Hillier, J. (2003). 'Agon'izing over consensus: why Habermasian ideals cannot be 'real'. Planning Theory, 2(1), 37-59.

Hobson Haggerty, J. (2007). "I'm not a greenie but ...": environmentality, eco-populism and governance in New Zealand experiences from the Southland whitebait fishery. Rural Studies, 23(2), 222-237.

Hoggart, K., Lees, L., \& Davies, A. (2002). Researching Human Geography. London: Arnold.

Horsley, E., \& Galloway, J. (2012). One Plan ruling divides opinion. Retrieved from http://www.stuff.co.nz/manawatu-standard/news/7622685/One-Plan-ruling-dividesopinion

Houlbrooke, D. J., Paton, R. J., Littlejohn, R. P., \& Morton, J. D. (2011). Land-use intensification in New Zealand: effects on soil properties and pasture production. Journal of Agricultural Science, 149, 337-349.

Hoverman, S., \& Ayre, M. (2012). Methods and approaches to support Indigenous water planning: an example from the Tiwi Islands, Northern Territory, Australia. Journal of Hydrology, 474, 47-56.

Howitt, R., Doohan, K., Suchet-Pearson, S., Cross, S., Lawrence, R., Lunkapis, G. J., et al. (2013). Intercultural capacity deficits: contested geographies of coexistence in natural resource management. Asia Pacific Viewpoint, 54(2), 126-140.

Howitt, R., \& Hillman, M. (2010). Environmental justice and the Commons. In S. J. Smith, R. Pain, S. A. Marston \& J. P. Jones (Eds.), The SAGE Handbook of Social Geographies (pp. 455-473). London; Los Angeles: SAGE.

Howitt, R., \& Lunkapis, G. J. (2010). Coexistence: planning and the challenge of Indigenous rights. In J. Hillier \& P. Healey (Eds.), The Ashgate Research Companion to Planning Theory: Conceptual Challenges for Spatial Planning (pp. 109-133). Surrey, England; Burlington; USA: Ashgate.

Howitt, R., \& Stevens, S. (2010). Cross-cultural research: ethics, methods, and relationships. In I. Hay (Ed.), Qualitative Research Methods in Human Geography (3rd ed., pp. 40-67). Oxford; New York: Oxford University Press. 
Howitt, R., \& Suchet-Pearson, S. (2006). Rethinking the building blocks: ontological pluralism and the idea of 'management'. Geografiska Annaler Series B, Human Geography, 88(3), 323-335.

Hughey, K. F. D. (2011, 13-15 December). How getting the 'demand side' right, by empowering community led initiatives, is leading to sustainable management of freshwater in New Zealand. Paper presented at the Sustainable Water Management for Food Security, Bogor, Indonesia.

Huntington, S. P. (1993). The clash of civilizations? Foreign Affairs, 72(3), 22-49.

Hurunui District Council. (2009a). Agenda for a meeting of the Hurunui District Council Tuesday 17 November. Retrieved from http://www.hurunui.govt.nz/assets/Documents/MinutesAgendas/Council/2009/0911 17-Council-Agenda-Runanga-Hearings.pdf

Hurunui District Council. (2009b). Minutes of an ordinary council meeting of the Hurunui District Council Thursday 30 July 2009 Retrieved from http://www.hurunui.govt.nz/assets/Documents/MinutesAgendas/Council/2009/0907 30\%20Council\%20Minutes.pdf

Hurunui District Council. (2009c). Minutes of the ordinary meeting of the Hurunui District Council Thursday 26 November 2009. Retrieved from http://www.hurunui.govt.nz/assets/Documents/MinutesAgendas/Council/2009/0911 26\%20Council\%20Minutes.pdf

Hurunui District Council. (2009d). Minutes of the ordinary meeting of the Hurunui District Council Tuesday 17 November 2009. Retrieved from http://www.hurunui.govt.nz/assets/Documents/MinutesAgendas/Council/2009/0911 17\%20Council\%20Minutes.pdf

Hurunui Waiau Zone Committee. (2010). Agenda for an ordinary meeting of the HurunuiWaiau Zone Committee Monday 26 July. Retrieved from http://ecan.govt.nz/publications/Council/hurunui-waiau-zone-committee-agenda260710.pdf

Hurunui Waiau Zone Committee. (2011a). Agenda for an ordinary meeting of the HurunuiWaiau Zone Committee Monday 19 September. Retrieved from http://ecan.govt.nz/publications/Council/cw-hurunui-waiau-agenda-190911.pdf

Hurunui Waiau Zone Committee. (2011b). Hurunui Waiau zone implementation programme. Retrieved from http://ecan.govt.nz/publications/General/hurunui-waiau-zip.pdf 
Hurunui Waiau Zone Committee. (2011c). Minutes of the ordinary meeting of the HurunuiWaiau Zone Committee 12 May 2011. Retrieved from http://ecan.govt.nz/publications/Council/cw-huruni-waiau-zone-committee-minutes120511.pdf

Hurunui Water Project. (n.d.). Hurunui Water Project - what is HWP? Retrieved from http://www.hurunuiwater.co.nz/

Hutching, C. (2009). New Ngai Tahu board reflects internal wrangle. Retrieved from http://www.nbr.co.nz/article/new-ngai-tahu-board-reflects-internal-wrangle-114007

Hutching, C. (2010). Q \& A: the Environment Canterbury saga. Retrieved from http://www.nbr.co.nz/article/qa-the-environment-canterbury-saga-123099

Hutchings, J. (2006). (Re)negotiating (bi)cultural environmental management under the Resource Management Act. In M. Mulholland (Ed.), State of the Māori Nation: TwentyFirst-Century Issues in Aotearoa (pp. 95-105). Auckland: Reed.

Ingold, T. (2010). Bringing things to life: creative entanglements in a world of materials. Realities Working Paper 15. Retrieved from http://www.socialsciences.manchester.ac.uk/realities/publications/workingpapers/15 -2010-07-realities-bringing-things-to-life.pdf

Innes, J. E., \& Booher, D. E. (2004). Reframing public participation: strategies for the 21st century. Planning Theory and Practice, 5(4), 419-436.

Innes, J. E., \& Booher, D. E. (2010). Planning with Complexity: An Introduction to Collaborative Rationality for Public Policy. Abingdon, UK; New York, USA: Routledge.

Inns, J. (2005). Thinking globally, acting locally? The New Zealand government, foreshore and seabed, international human rights and double standards. In G. Cant, A. Goodall \& J. Inns (Eds.), Discourses and Silences: Indigenous Peoples, Risks and Resistance (pp. 219230). Christchurch: Department of Geography, University of Canterbury.

Ioris, A. A. R. (2012). Applying the strategic-relational approach to urban political ecology: the water management problems of the Baixada Fluminense, Rio de Janeiro, Brazil. Antipode, 44(1), 122-150.

IrrigationNZ. (2012). Last minute changes weaken Land and Water Forum report. Retrieved from http://www.irrigationnz.co.nz/news/media-releases/last-minute-changesweaken-land-and-water-forum-report/ 
Jackson, M. (2005). The face behind the law: the United Nations and the rights of indigenous peoples. Yearbook of New Zealand Jurisprudence, 8(2), 10-30.

Jackson, P. (1998). Constructions of 'whiteness' in the geographical imagination. Area, 30(2), 99-106.

Jackson, S. (2006). Compartmentalising culture: the articulation and consideration of Indigenous values in water resource management. Australian Geographer, 37(1), 1931.

Jessop, B. (2007). From micro-powers to governmentality: Foucault's work on statehood, state formation, statecraft and state power. Political Geography, 26(1), 34-40.

Johnsen, S. (2003). Contingency revealed: New Zealand farmers' experiences of agricultural restructuring. Sociologia Ruralis, 43(2), 128-153.

Johnson, J. T., Cant, G., Howitt, R., \& Peters, E. (2007). Guest editorial: Creating anti-colonial geographies: embracing Indigenous peoples' knowledges and rights. Geographical Research, 45(2), 117-120.

Johnson, J. T., \& Murton, B. (2007). Re/placing native science: Indigenous voices in contemporary constructions of nature. Geographical Research, 45(2), 121-129.

Jojola, T. (1998). Indigenous planning: clans, intertribal confederations and the history of the all Indian Pueblo Council. In L. Sandercock (Ed.), Making the Invisible Visible: A Multicultural History of Planning (pp. 100-119). Berkeley: University of California Press.

Jones, O. (2009). After nature: entangled worlds. In N. Castree, D. Demeritt, D. Liverman \& B. Rhoads (Eds.), A Companion to Environmental Geography (pp. 294-312). Chichester, UK; Maldon, MA: Wiley-Blackwell.

Jones, O. (2011). Lunar - solar rhythmpatterns: towards the material cultures of tides. Environment and Planning A, 43(10), 2285-2303.

Jones, S. (2008). Political ecology and land degradation: how does the land lie 21 years after Blaikie and Brookflied's Land Degradation and Society? Geography Compass, 2(3), 671694.

Joseph, A. E., \& Chalmers, A. I. (1998). Coping with rural change: finding a place for the elderly in sustainable communities. New Zealand Geographer, 54(2), 28-36. 
Joseph, P. (2010). Environment Canterbury legislation. New Zealand Law Journal(June), 193196.

Kadirbeyoğlu, Z., \& Kurtiç, E. (2013). Problems and prospects for genuine participation in water governance in Turkey. In L. M. Harris, J. A. Goldin \& C. Sneddon (Eds.), Contemporary Water Governance in the Global South: Scarcity, Marketization and Participation (pp. 199-215). Abingdon, UK; New York, USA;: Routledge.

Kaika, M. (2006). The political ecology of water scarcity: the 1989-1991 Athenian drought. In N. Heynen, M. Kaika \& E. Swyngedouw (Eds.), In the Nature of Cities: Urban Political Ecology and the Politics of Urban Metabolism (pp. 157-172). New York: Routledge.

Kaikōura District Council. (2008). Kaikōura District Plan. Retrieved from http://www.kaikoura.govt.nz/council documents/district plan/index.htm

Kapoor, I. (2004). Hyper-self-reflexive development? Spivak on representing the Third World 'Other'. Third World Quarterly, 25(4), 627-647.

Kapoor, I. (2005). Participatory development, complicity and desire. Third World Quarterly, 26(8), 1203-1220.

Karlsson, R. (2013). Ambivalence, irony, and democracy in the Anthropocene. Futures, 46, 1-9.

Katz, C. (1994). Playing the field: questions of fieldwork in geography. Professional Geography, 46(1), 67-72.

Kearns, R. A. (2010). Seeing with clarity: undertaking observational research. In I. Hay (Ed.), Qualitative Research Methods in Human Geography (3rd ed., pp. 241-258). Melbourne: Oxford University Press.

Kedgley, S. (2013). Govt meddling in council affairs troubling to all. Retrieved from http://www.nzherald.co.nz/opinion/news/article.cfm?c id=466\&objectid=10873569

Keene, H. (2013). North Canterbury irrigation scheme a step closer. Retrieved from http://www.stuff.co.nz/business/farming/agribusiness/9092500/North-Canterburyirrigation-scheme-a-step-closer

Kelsey, J. (1995). The New Zealand Experiment: a World Model for Structural Adjustment? Auckland: Auckland University Press with Bridget Williams Books.

Kelsey, J. (1997). Employment and union issues in New Zealand - 12 years on. California Western International Law Journal, 28, 253-274. 
Kindon, S., Pain, R., \& Kesby, M. (2007). Introduction: connecting people, participation and place. In S. Kindon, R. Pain \& M. Kesby (Eds.), Participatory Action Research Approaches and Methods: Connecting People, Participation and Place (pp. 1-5). London: Routledge.

Kindon, S. L. (2012). 'Thinking-through-complicity' with Te Iwi o Ngāti Hauiti: towards a critical use of participatory video for research (Unpublished PhD Thesis). University of Waikato.

Kingfisher, C. (2007). Spatializing neoliberalism: articulations, recapitulations and (a very few) alternatives. In K. England \& K. Ward (Eds.), Neoliberalization: States, Networks, Peoples (pp. 195-222). Malden, MA: Blackwell Publishing.

Kitchin, R., \& Tate, N. J. (2000). Conducting Research into Human Geography: Theory, Methodology and Practice. Harlow, UK: Prentice Hall.

Klein, N. (2001). Sign of the times. Retrieved from http://www.thenation.com/article/signstimes-0\#axzz2Zpi2HSWN

Knigge, L., \& Cope, M. (2006). Grounded visualization: integrating the analysis of qualitative and quantitative data through grounded theory and visualization. Environment and Planning A, 38(11), 2021-2037.

Kobayashi, A. (1994). Coloring the field: gender, "race," and the politics of fieldwork. The Professional Geographer, 46(1), 73 - 80.

Kobayashi, A. (2003). GPC ten years on: is self-reflexivity enough? Gender, Place and Culture, 10(4), 345-349.

Laclau, E., \& Mouffe, C. (1985). Hegemony and Socialist Strategy. London: Verso Press.

Land and Water Forum. (2010). Report of the Land and Water Forum: a fresh start for freshwater. Retrieved from http://www.landandwater.org.nz/index.htm

Larner, W. (1995). Theorising 'difference' in Aotearoa/New Zealand. Gender, Place and Culture, 2(2), 177-190.

Larner, W. (1997). "A means to an end": neoliberalism and state processes in New Zealand. Studies in Political Economy, 52(Spring), 7-38.

Larner, W. (1998). Hitching a ride on the tiger's back: globalisation and spatial imaginaries in New Zealand. Environment and Planning D, 16, 599-614. 
Larner, W. (2000a). Neo-liberalism: policy, ideology, governmentality. Studies in Political Economy, 63, 5-25.

Larner, W. (2000b). Post-welfare state governance: towards a code of social and family responsibility. Social Politics, 7(2), 244-265.

Larner, W. (2003). Neoliberalism? Environment and Planning D, 21(5), 509-512.

Larner, W. (2006). Brokering citizenship claims: neo-liberalism, biculturalism and multiculturalism in Aotearoa New Zealand. In E. Tastsoglou \& A. Dobrowolsky (Eds.), Women, Migration and Citizenship: Making Local, National and Transnational Connections (pp. 131-148). Aldershot, England; Burlington, USA: Ashgate.

Larner, W. (2007). Neoliberal governmentalities. In N. Heynen, McCarthy, J., Prudham, S., and Robbins, P. (Ed.), Neoliberal Environments: False Promises and Unnatural Consequences (pp. 217-220). London; New York: Routledge.

Larner, W. (2011). C-change? Geographies of crisis. Dialogues in Human Geography, 1(3), 319335.

Larner, W., \& Butler, M. (2005). Governmentalities of local partnerships: the rise of a "partnering state" in New Zealand. Studies in Political Economy, 75, 85-108.

Larner, W., \& Butler, M. (2007). The places, people, and politics of partnership: "after neoliberalism" in Aotearoa New Zealand. In H. Leitner, J. Peck \& E. S. Sheppard (Eds.), Contesting Neoliberalism: Urban Frontiers. New York: Guilford Press.

Larner, W., \& Craig, D. (2005). After neoliberalism? Community activism and local partnerships in Aotearoa New Zealand. Antipode, 37(3), 402-424.

Larner, W., Le Heron, R., \& Lewis, N. (2007). Co-constituting "after neoliberalism": political projects and globalizing governmentalities in Aotearoa/New Zealand. In K. England \& K. Ward (Eds.), Neoliberalization: States, Networks, Peoples (pp. 223-247). Malden, MA: Blackwell Publishing.

Latour, B. (1993). We Have Never Been Modern. Cambridge, MA: Harvard University Press.

Law, J., \& Mol, A. (2008). The actor-enacted: Cumbrain sheep in 2001. In C. Knappett \& L. Malafouris (Eds.), Material Agency: Towards a Non-Anthropocentric Approach (pp. 5777). Heidelberg: Springer. 
Le Heron, R., \& Roche, M. (1999). Rapid reregulation, agricultural restructuring, and the reimagining of agriculture in New Zealand. Rural Sociology, 64(2), 203-218.

Leach, M., Bloom, G., Ely, A., Nightingale, P., Scoones, I., Shah, E., et al. (2007). Understanding governance: pathways to sustainability. STEPS Working Paper 2. STEPS Centre. Brighton.

Lewis, N. (2009). Progressive spaces of neoliberalism? Asia Pacific Viewpoint, 50(2), 113-119.

Lewis, N. (2012). Splitting a northern account of New Zealand's neoliberalism. New Zealand Geographer, 68(3), 168-174.

$\mathrm{Li}, \mathrm{T} . \mathrm{M}$. (1996). Images of community: discourse and strategy in property relations. Development and Change, 27(3), 501-527.

Li, T. M. (2002). Engaging simplifications: community-based resource management, market processes and state agendas in upland Southeast Asia. World Development, 30(2), 265-283.

Li, T. M. (2007). Practices of assemblage and community forest management. Economy and Society, 36(2), 263-293.

Liepins, R. (1998). The gendering of farming and agricultural politics: a matter of discourse and power. Australian Geographer, 29(3), 371-388.

Liepins, R. (2000a). Exploring rurality through 'community': discourses, practices and spaces shaping Australian and New Zealand rural 'communities'. Journal of Rural Studies, 16(3), 325-341.

Liepins, R. (2000b). New energies for an old idea: reworking approaches to 'community' in contemporary rural studies. Journal of Rural Studies, 16(1), 23-35.

Little, J., \& Panelli, R. (2003). Gender research in rural geography. Gender, Place and Culture, 10(3), 281-289.

Loeffen, A. (2009, 29 July). Jobs, better life from water. The Press.

Loeffen, A. (2012). Revised project offers many benefits. Retrieved from http://www.stuff.co.nz/the-press/opinion/perspective/7657458/Revised-projectoffers-many-benefits 
Loftus, A., \& Lumsden, F. (2008). Reworking hegemony in the urban waterscape. Transactions of the Institute of British Geographers, 33(1), 109-126.

Lomax, A., Memon, A., \& Painter, B. (2010). The Canterbury Water Management Strategy as a collaborative planning initiative: a preliminary assessment. Lincoln: Lincoln Ventures Ltd

Maaka, R., \& Fleras, A. (2005). The Politics of Indigeneity: Challenging the State in Canada and Aotearoa New Zealand. Dunedin: University of Otago Press.

MacDonald, L. T. A. T., \& Muldoon, P. (2006). Globalisation, neo-liberalism and the struggle for indigenous citizenship. Australian Journal of Political Science, 41(2), 209-223.

Macfie, R. (2010, 14 August). The price of milk. NZ Listener, 225(3666), 16-23.

Mansfield, B. (2004). Neoliberalism in the oceans: "rationalization," property rights, and the commons question. Geoforum, 35(3), 313-326.

Mansfield, B. (2009). Sustainability. In N. Castree, D. Demeritt, D. Liverman \& B. Rhoads (Eds.), A Companion to Environmental Geography (pp. 37-49). Chichester, UK; Maldon, MA: Wiley-Blackwell.

Mansvelt, J., \& Berg, L. D. (2010). Writing qualitative geographies, constructing meaningful geographical knowledges. In I. Hay (Ed.), Qualitative Research Methods in Human Geography (3rd ed., pp. 333-355). Oxford; New York: Oxford University Press.

Martinez-Alier, J., Kallis, G., Veuthey, S., Walter, M., \& Temper, L. (2010). Social metabolism, ecological distribution conflicts, and valuation languages. Ecological Economics, 70(2), $153-158$.

Massey, D. (1993). Power-geometry and a progressive sense of place. In J. Bird, B. Curtis, T. Putman, G. Robertson \& L. Tickner (Eds.), Mapping the Futures: Local Cultures, Global Change (pp. 59-69). London; New York: Routledge.

Masuda, J. R., McGee, T. K., \& Garvin, T. D. (2008). Power, knowledge, and public engagement: constructing 'citizenship' in Alberta's industrial heartland. Journal of Environmental Policy and Planning, 10(4), 359-380.

Maxey, I. (1999). Beyond boundaries? Activism, academia, reflexivity and research. Area, 31(3), 199-208.

McCarthy, J. (2005). Devolution in the woods: community forestry as hybrid neoliberalism. Environment and Planning A, 37(6), 995-1014. 
McCarthy, J. (2006). Neoliberalism and the politics of alternatives: community forestry in British Columbia and the United States. Annals of the Association of American Geographers, 96(1), 84-104.

McCarthy, J. (2013). We have never been "post-political". Capitalism Nature Socialism, 24(1), 19-25.

McCarthy, J., \& Prudham, S. (2004). Neoliberal nature and the nature of neoliberalism. Geoforum, 35(3), 275-283.

McClean, R., Berg, L. D., \& Roche, M. M. (1997). Responsible geographies: co-creating knowledge in Aotearoa. New Zealand Geographer, 53(2), 9-15.

McCrone, J. (2011, 22-23 January 2011). Smoothing the waters. The Press, pp. C1-3.

McCrone, J. (2013). Ngai Tahu's reach shapes a new city. Retrieved from http://www.stuff.co.nz/the-press/news/8198076/Ngai-Tahus-reach-shapes-a-new-city

McDowell, L. (1992). Doing gender: feminism, feminists and research methods in human geography. Transactions of the Institute of British Geographers, 17(4), 399 - 416.

McDowell, L. (2010). Interviewing: fear and liking in the field. In D. DeLyser, S. Herbert, S. Aitken, M. Crang \& L. McDowell (Eds.), The SAGE Handbook of Qualitative Geography (pp. 156-172). London: SAGE.

McGregor, A. (2004). Sustainable development and 'warm fuzzy feelings': discourse and nature within Australian environmental imaginaries. Geoforum, 35(5), 593 - 606.

McGregor, A. (2005). Negotiating nature: exploring discourse through small group research. Area, 37(4), 423-432.

McKinnon, K. (2011). Identification. In V. J. Del Casino, M. E. Thomas, P. Cloke \& R. Panelli (Eds.), A Companion to Social Geography (pp. 37-54). Oxford: Blackwell.

McRae, S. (1993). Hurunui: Source to Sea. Christchurch: Hurunui Press.

Mehta, L., Leach, M., \& Scoones, I. (2001). Editorial: Environmental governance in an uncertain world. IDS Bulletin, 32(4), 1-9. 
Memon, A., Duncan, R., \& Spicer, A. (2012). The Hurunui Waiau Zone Implementation Programme as a collaborative planning process: a preliminary review (R12/46). Environment Canterbury

Memon, A., \& Skelton, P. (2007). Institutional arrangements and planning practices to allocate freshwater resources in New Zealand: a way forward. New Zealand Journal of Environmental Law, 11, 241-277.

Memon, A., \& Weber, E. (2008, June 6). Collaborative water governance in New Zealand: turning the tide in the Canterbury region? Paper presented at the International Symposium on Society and Resource Management Conference, University Vermont.

Memon, A., \& Weber, E. P. (2010). Overcoming obstacles to collaborative water governance: moving toward sustainability in New Zealand. Journal of Natural Resources Policy Research, 2(2), 103-116.

Memon, P. A. (1997). Case studies and reviews: freshwater management policies in New Zealand. Aquatic Conservation: Marine and Freshwater Ecosystems, 7, 305-322.

Memon, P. A., \& Gleeson, B. J. (1995). Towards a new planning paradigm? Reflections on New Zealand's Resource Management Act. Environment and Planning B, 22, 109-124.

Memon, P. A., \& Kirk, N. (2012). Role of indigenous Māori people in collaborative water governance in Aotearoa/New Zealand. Journal of Environmental Planning and Management, 55(7), 941-959.

Memon, P. A., \& Kirk, N. A. (2011). Maori commercial fisheries governance in Aotearoa/New Zealand within the bounds of a neoliberal fisheries management regime. Asia Pacific Viewpoint, 52(1), 106-118.

Ministry for Agriculture and Forestry. (2009). Briefing on facilitating irrigation development in Canterbury.

Ministry for Primary Industries. (2011). International trade: agricultural and forestry exports from New Zealand. Retrieved from http://www.mpi.govt.nz/news-resources/statisticsforecasting/international-trade.aspx

Ministry for the Environment. (2009). Special Tribunal's report on application for a Water Conservation Order on the Hurunui River. Retrieved from http://www.mfe.govt.nz/issues/water/freshwater/water-conservation/hurunuitribunals-report.html 
Ministry for the Environment. (2013a). Freshwater reform 2013 and beyond. Wellington: Ministry for the Environment.

Ministry for the Environment. (2013b). Long-term change. Retrieved from http://www.mfe.govt.nz/environmental-reporting/fresh-water/river-conditionindicator/nutrient/long-term-change.html

Ministry for the Environment. (2013c). Suitability for swimming: indicator update. Retrieved from http://www.mfe.govt.nz/environmental-reporting/fresh-water/suitability-forswimming-indicator/suitability-swimming-indicator.html

Ministry of Business Innovation and Employment. (2012). Youth labour market factsheet - June 2012. Retrieved from http://www.dol.govt.nz/publications/Imr/pdfs//mr-fs/lmr-fsyouth-jun12.pdf

Miraftab, F. (2009). Insurgent planning - situating radical planning in the global South. Planning Theory, 8(1), 32-50.

Moeke-Maxwell, T. (2003, 30 November - 2 December). 'Bring home the body': bi/multi racial Maori women's hybridity in Aotearoa New Zealand. Paper presented at the NZARE/ARRE Conference, University of Auckland.

Monbiot, G. (1994). The tragedy of the enclosure. The Social Contract, 27(Spring), 159.

Moran, W., Bang, B., Memon, A., Trost, P., Perkins, H., Fielding, P., et al. (1992). Local government reform. In S. Britton, Le Heron, R. and Pawson, E. (Ed.), Changing Places in New Zealand: a Geography of Restructuring (pp. 215-237). Christchurch: New Zealand Geographical Society.

Morinville, C., \& Harris, L. M. (2013). Participation's limits: tracing the contours of participatory water governance in Accra, Ghana. In L. M. Harris, J. A. Goldin \& C. Sneddon (Eds.), Contemporary Water Governance in the Global South: Scarcity, Marketization and Participation (pp. 216-). Abingdon, UK; New York, USA;: Routledge.

Mouffe, C. (2000). The Democratic Paradox. London: Verso.

Mouffe, C. (2005). On The Political. New York: Routledge.

Muir, C., Rose, D., \& Sullivan, P. (2010). From the other side of the knowledge frontier: Indigenous knowledge, social-ecological relationships and new perspectives. The Rangeland Journal, 32(3), 259-265. 
Murdoch, J. (1997). The shifting territory of government: some insights from the Rural White Paper. Area, 29(2), 109-118.

Mutu, M. (1994). The use and meaning of Maori words borrowed into English for discussing resource management and conservation in Aotearoa/New Zealand. Unpublished discussion paper for Conservation Board Chairpersons.

Mutu, M. (2010). Māori issues. The Contemporary Pacific, 22(1), 179-184.

Nairn, K., \& Higgins, J. (2007). New Zealand's neoliberal generation: tracing discourses of economic (ir)rationality. International Journal of Qualitative Studies in Education, 20(3), 261-281.

Nast, H. J. (1994). Women in the field: critical feminist methodologies and theoretical perspectives. The Professional Geographer, 46(1), 54-66.

Nast, H. J. (1998). The body as "place": reflexivity and fieldwork in Kano, Nigeria. In H. J. Nast \& S. Pile (Eds.), Places Through the Body (pp. 93-116). London; New York: Routledge.

Neumann, R. P. (2009). Political ecology: theorizing scale. Progress in Human Geography, 33(3), 398-406.

New Zealand Government. (1991). Resource Management Act No 69.

New Zealand Law Society. (2013). Strengthening of human rights protection mechanisms urged. Retrieved from http://www.lawsociety.org.nz/home/for-the-public/for-themedia/latest-news/news/june-2013/strengthening-of-human-rights-protectionmechanisms-urged

New Zealand Parliament. (1998). Ngai Tahu Claims Settlement Act (pp. 692).

Environment Canterbury (Temporary Commissioners and Improved Water Management) Act

Ngāi Tahu Holdings Corporation. (2013). Group profile. Retrieved from http://www.ngaitahuholdings.co.nz/group-profile/

Ngai Tūhoe. (2013). About Tūhoe settlement. Retrieved from http://www.ngaituhoe.iwi.nz/Settlement/AboutTūhoeSettlement.aspx

NZGS-PG Network. (forthcoming). Postgraduates performing powerfully in a changing academic environment. New Zealand Geographer 
O'Regan, T., Palmer, L., \& Langton, M. (2006). Keeping the fires burning: grievance and aspiration in the Ngāi Tahu settlement. In M. Langton, O. Mazel, L. Palmer, K. Shain \& M. Tehan (Eds.), Settling with Indigenous People (pp. 44-65). Sydney: The Federation Press.

O'Sullivan, P. (2013). Council denies information withheld over Ruataniwha. Retrieved from http://www.nzherald.co.nz/hawkes-baytoday/news/article.cfm?c id=1503462\&objectid $=11128182$

Officer of the Minister for the Environment. (2010). Response to review of Environment Canterbury: Cabinet Paper. Retrieved from http://www.mfe.govt.nz/cabinetpapers/cab-ecan-response-to-review-of-environment-canterbury.pdf

Oram, R. (2007, 30-31 May). The Resource Management Act: now and in the future. Paper presented at the Beyond the RMA Conference, The Langham, Auckland.

Oram, R. (2013). A naked power grab. Stuff.co.nz. Retrieved from http://www.stuff.co.nz/business/opinion-analysis/8400307/Oram-A-naked-powergrab

Page, B., \& Bakker, K. (2005). Water governance and water users in a privatised water industry: participation in policy-making and in water services provision: a case study of England and Wales. International Journal of Water, 3(1), 38-60.

Palmer, G. (2013). Protecting New Zealand's environment: an analysis of the government's proposed freshwater management and Resource Management Act 1991 reforms. Retrieved from http://rivers.org.nz/system/files/Fish\%20and\%20Game\%20RMA\%20Paper\%20\%20FINAL\%20PRINT.pdf

Palmer, L. (2006). 'Nature', place and the recognition of Indigenous polities. Australian Geographer, 37(1), 33-43.

Panelli, R. (2003). A countryside for life? Constructing and participating in rural planning. Planning Theory and Practice, 4(1), 89-92.

Panelli, R. (2008). Social geographies: encounters with Indigenous and more-than-White/Anglo geographies. Progress in Human Geography, 32(6), 801-811.

Panelli, R. (2010). More-than-human social geographies: posthuman and other possibilities. Progress in Human Geography, 34(1), 79-87. 
Panelli, R., Hubbard, P., Coombes, B., \& Suchet-Pearson, S. (2009). De-centring White ruralities: ethnic diversity, racialisation and Indigenous countrysides. Journal of Rural Studies, 25(4), 355-364.

Panelli, R., Little, J., \& Kraack, A. (2004). A community issue? Rural women's feelings of safety and fear in New Zealand. Gender, Place and Culture, 11(3), 445-467.

Panelli, R., \& Tipa, G. (2007). Placing well-being: a Maori case study of cultural and environmental specificity. EcoHealth, 4(4), 445-460.

Parker, B. (2010, 10 March). Solution must fit us all. The Press.

Parliamentary Commissioner for the Environment. (2012). Hydroelectricity or wild rivers? Climate change versus natural heritage.

Pauling, C. (2008, 11-12 June). Ngā Wai Pounamu: cultural health assessment of South Island Waterways. Paper presented at the Environmental Defence Society Conference, Auckland.

Pawson, E., Roche, M., Johnson, R., Banks, G., Morgan, R., Holland, P., et al. (1992). The environment. In S. Britton, Le Heron, R. and Pawson, E. (Ed.), Changing Places in New Zealand: a Geography of Restructuring (pp. 187-214). Christchurch: New Zealand Geographical Society.

Pearce, J., \& Kingham, S. (2008). Environmental inequalities in New Zealand: A national study of air pollution and environmental justice. Geoforum, 39(2), 980-993.

Peck, J. (2004). Geography and public policy: constructions of neoliberalism. Progress in Human Geography, 28(3), 392-405.

Peck, J., \& Tickell, A. (2002). Neoliberalizing space. Antipode, 34(3), 380-404.

Peet, R., Robbins, P., \& Watts, M. J. (2011). Global nature. In R. Peet, P. Robbins \& M. J. Watts (Eds.), Global Political Ecology (pp. 1-47). London; New York: Routledge.

Peluso, N. (1992). Rich Forests, Poor People. Berkeley: University of California Press.

Peluso, N. L. (2008). Enclosure and privatization of neoliberal environments. In N. Heynen, McCarthy, J., Prudham, S., and Robbins, P. (Ed.), Neoliberal Environments: False Promises and Unnatural Consequences (pp. 89-93). London and New York: Routledge. 
Penley, C., Ross, A., \& Haraway, D. (1990). Cyborgs at large: interview with Donna Haraway. Social Text, 25/26, 8-23.

Perreault, T. (2006). From the Guerra Del Agua to the Guerra Del Gas: resource governance, neoliberalism and popular protest in Bolivia. Antipode, 38(1), 150-172.

Peterson, M. N., Peterson, M. J., \& Peterson, T. R. (2005). Conservation and the myth of consensus. Conservation Biology, 19(3), 762-767.

Pickerill, J. (2008). From wilderness to WildCountry: the power of language in environmental campaigns in Australia. Environmental Politics, 17(1), 95-104.

Plumwood, V. (1992). Feminism and ecofeminism: beyond the dualistic assumptions of women, men and nature. The Ecologist, 22(1), 8-13.

Plumwood, V. (2003). Animals and ecology: towards a better integration. Unpublished article in ANU Digital Collection: http://hdl.handle.net/1885/41767.

Pomeroy, A. (2011a). Rural community resilience and climate change Report to the Ministry of Agriculture and Forestry: Centre for Sustainability: Agriculture, Food, Energy, Environment.

Pomeroy, A. (2011b). Rural community resilience and climate change - background papers. In J. Newell (Ed.), Report to the Ministry of Agriculture and Forestry (Vol. 2): Centre for Sustainability: Agriculture, Food, Energy, Environment.

Popke, J. (2006). Geography and ethics: everyday mediations through care and consumption. Progress in Human Geography, 30(4), 504-512.

Porter, L. (2006). Planning in (post)colonial settings: challenges for theory and practice. Planning Theory and Practice, 7(4), 383-396.

Porter, L. (2010). Unlearning the Colonial Cultures of Planning. Surrey, England; Burlington, USA: Ashgate.

Potts, A., \& Haraway, D. (2010). Kiwi chicken advocate talks with Californian dog companion. Feminism and Psychology, 20(3), 318-336.

Pratt, G. (2009a). Performativity. In D. Gregory, R. Johnson, G. Pratt, M. J. Watts \& S. Whatmore (Eds.), The Dictionary of Human Geography (pp. 526-527). Chichester: John Wiley and Sons. 
Pratt, G. (2009b). Subject/subjectivity. In D. Gregory, R. Johnson, G. Pratt, M. J. Watts \& S. Whatmore (Eds.), The Dictionary of Human Geography (5th ed., pp. 728-731).

Chichester: John Wiley and Sons.

Pratt, K. (2012). Rethinking community: conservation, practice, and emotion. Emotion, Space and Society, 5(3), 177-185.

Prince, R., Kearns, R., \& Craig, D. (2006). Governmentality, discourse and space in the New Zealand health care system, 1991-2003. Health and Place, 12(3), 253-266.

Probyn, E. (2003). The spatial imperative of subjectivity. In K. Anderson, M. Domosh, S. Pile \& N. Thrift (Eds.), Handbook of Cultural Geography (pp. 290-299). London: Sage.

Prout, S., \& Howitt, R. (2009). Frontier imaginings and subversive Indigenous spatialities. Journal of Rural Studies, 25(4), 396-403.

Prudham, S. (2009). Commodification. In N. Castree, D. Demeritt, D. Liverman \& B. Rhoads (Eds.), A Companion to Environmental Geography (pp. 123-142). Chichester, UK; Maldon, MA: Wiley-Blackwell.

Purcell, M. (2009). Resisting neoliberalization: communicative planning or counter-hegemonic movements? Planning Theory, 8(2), 140-165.

Putnam, R. D. (2001). Bowling Alone: the Collapse and Revival of American Community. London: Simon and Schuster.

Raco, M., \& Imrie, R. (2000). Governmentality and rights and responsibilities in urban policy. Environment and Planning A, 32, 2187-2204.

Raco, M., \& Lin, W.-I. (2012). Urban sustainability, conflict management, and the geographies of postpoliticism: a case study of Taipei. Environment and Planning C, 30(2), 191-208.

Radio New Zealand. (2010). Urgent need for national water strategy - INZ. Retrieved from http://www.radionz.co.nz/news/rural/2455/urgent-need-for-national-water-strategy$\underline{\text { inz }}$

Radio New Zealand. (2013a). Group denied entry to Cathedral Square. Retrieved from http://www.radionz.co.nz/news/canterbury-earthquake/129894/group-denied-entryto-cathedral-square

Radio New Zealand. (2013b). The Maori Party says the announcement of a new marine reserve in Canterbury cuts across Maori customary rights. Retrieved from 
http://www.radionz.co.nz/news/te-manu-korihi/132895/maori-party-says-marinereserve-limits-customary-rights

Radio New Zealand. (2013c). Midday rural news for 12 July 2013. Retrieved from http://www.radionz.co.nz/national/programmes/ruralnews/audio/2561876/middayrural-news-for-12-july-2013

Ramsey, K. (2008). A call for agonism: GIS and the politics of collaboration. Environment and Planning A, 40(10), 2346-2363.

Rancière, J. (1998). Disagreement. Minneapolis: University of Minnesota Press.

Rancière, J. (2001). Ten theses on politics. Theory and Event, 5(3)

Rangahau. (n.d.). Research proposal. Retrieved from http://www.rangahau.co.nz/researchproposal/

Rata, E. (2011). Encircling the commons: neotribal capitalism in New Zealand since 2000. Anthropological Theory, 11(3), 327-353.

Rennie, H. G. (2010). The ECan Act: understanding the new provisions for planners. Lincoln Planning Review, 2(2), 20-21.

Ribot, J. C. (2006). Choose democracy: environmentalists' socio-political responsibility. Global Environmental Change, 16(2), 115-119.

Robbins, P. (2004). Political Ecology. Malden, MA: Blackwell.

Robbins, P. (2012). Political Ecology (2nd ed.). Chichester, UK: Wiley-Blackwell.

Robbins, P., \& Luginbuhl, A. (2007). The last enclosure: resisting privatization of wildlife in the western United States. In N. Heynen, McCarthy, J., Prudham, S., and Robbins, P. (Ed.), Neoliberal Environments: False Promises and Unnatural Consequences (pp. 25-37). London; New York: Routledge.

Roberts, M., Norman, W., Minhinnick, N., Wihongi, D., \& Kirkwood, C. (1995). Kaitiakitanga: Maori perspectives on conservation. Pacific Conservation Biology, 2(1), 7-20.

Roberts, P. (2009). A new patriotism? Neoliberalism, citizenship and tertiary education in New Zealand. Educational Philosophy and Theory, 41(4), 410-423. 
Robertson, W. A. (1993). New Zealand's new legislation for sustainable resource management: the Resource Management Act 1991. Land Use Policy, 10(4), 303-311.

Robertson, W. A. (1996). Sustainable management and the market in New Zealand. Land Use Policy, 13(3), 213-215.

Robson, B. (2007). Economic determinants of Māori health and disparities. In M. Bargh (Ed.), Resistance: An Indigenous Response to Neoliberalism (pp. 45-61). Wellington: Huia.

Rocheleau, D., Thomas-Slayter, B., \& Wangari, E. (1996a). Gender and environment. In D. Rocheleau, B. Thomas-Slayter \& E. Wangari (Eds.), Feminist Political Ecology: Global Issues and Local Experiences (pp. 3-23). London; New York: Routledge.

Rocheleau, D., Thomas-Slayter, B., \& Wangari, E. (Eds.). (1996b). Feminist Political Ecology: Global Issues and Local Experiences. London; New York: Routledge

Roelvink, G., \& Craig, D. (2005). The man in the partnering state: regendering the social through partnership. Studies in Political Economy, 75, 103-126.

Rose, D. (2005). An indigenous philosophical ecology: situating the human. The Australian Journal of Anthropology, 16(3), 294-305.

Rose, G. (1997). Situating knowledges: positionality, reflexivities and other tactics. Progress in Human Geography, 21(3), 305-320.

Rose, N. (2000). Community, citizenship, and the third way. American Behavioral Scientist, 43(9), 1395-1411.

Rudzitis, G., \& Bird, K. (2011). The myth and reality of sustainable New Zealand: mining in a pristine land. Environment: Science and Policy for Sustainable Development, 53(6), 1628.

Said, E. (1979). Orientalism. New York: Vintage Books.

Salmond, A. (2013). A warning to New Zealanders keep hold of democracy. Retrieved from http://www.nzherald.co.nz/nz/news/article.cfm?c id=1\&objectid=10897497

Sandercock, L. (2004). Interface: planning and indigenous communities. Planning Theory and Practice, 5(1), 95-97.

Sargent, E. (2010, 8 May). The white gold is disappearing. The Press, p. C6. 
Saunders, C. (2009). Hurunui Water Project: economic analysis of the effects of the project. Riley Consultants Ltd

Scheyvens, H., \& Nowak, B. (2003). Personal issues. In R. Scheyvens \& D. Storey (Eds.), Development Fieldwork: A Practical Guide (pp. 96-116). London: Sage.

Sharp, J. (2005). Geography and gender: feminist methodologies in collaboration and in the field. Progress in Human Geography, 29(3), 304 - 309.

Simmonds, N. (2011). Mana wahine: decolonising politics. Women's Studies Journal, 25(2), 1125.

Simon, D. (2008). Political ecology and development: intersections, explorations and challenges arising from the work of Piers Blaikie. Geoforum, 39(2), 698 - 707.

Sington, D., \& Lamb, S. (Directors). (2013). Thin Ice.

Sinner, J. (2011). Implications of the National Policy Statement on freshwater management. Cawthron Report Number 1965

Slater, D. (2006). Imperial powers and democratic imaginations. Third World Quarterly, 27(8), 1369-1386.

Smith, L. (1999). Decolonizing Methodologies: Research and Indigenous People. Dunedin: University of Otago Press.

Smith, N. (2006a). Nature as accumulation strategy. In L. Panitch \& C. Leys (Eds.), Socialist Register 2007: Coming to terms with Nature (pp. 16-36). London: Merlin Press.

Smith, N. (2006b). Preface. In N. Heynen, M. Kaika \& E. Swyngedouw (Eds.), In the Nature of Cities: Urban Political Ecology and the Politics of Urban Metabolism (pp. xi-xv). New York: Routledge.

Smith, S. J. (2009). Everyday morality: where radical geography meets normative theory. Antipode, 41(1), 206-209.

Solomon, M. (2006). Ngai Tahu post-settlement. In M. Mulholland (Ed.), State of the Māori Nation: Twenty-First-Century Issues in Aotearoa (pp. 209-217). Auckland: Reed. 
Spoonley, P. (1995). Constructing ourselves: the post-colonial politics of Pakeha. In M. Wilson \& A. Yeatman (Eds.), Justice and Identity: Antipodean Practices (pp. 96-115). Wellington: Bridget Williams Books.

Springer, S. (2012a). Neoliberalising violence: of the exceptional and the exemplary in coalescing moments. Area, 44(2), 136-143.

Springer, S. (2012b). Neoliberalism as discourse: between Foucauldian political economy and Marxian poststructuralism. Critical Discourse Studies, 9(2), 133-147.

St. Martin, K. (2005). Disrupting enclosure in New England fisheries. Capitalism Nature Socialism, 16(1), 63-80.

Staeheli, L. A., Kofman, E., \& Peake, L. J. (Eds.). (2004). Mapping Women, Mapping Politics: Feminist Perspectives on Political Geography. New York: Routledge

Stevens, S. (1998). Conservation through Cultural Survival. Covelo, CA: Island Press.

Stewart, M. (2012). 100\% pure fantasy? Living up to our brand. Retrieved from http://www.stuff.co.nz/environment/8023412/100-Pure-Fantasy-Living-up-to-ourbrand

Stokes, E. (1987). Maori geography or geography of Maoris. New Zealand Geographer, 43(3), 118-123.

Stuff.co.nz. (2013). Nats plan to remove rights to oppose drilling. Retrieved from http://www.stuff.co.nz/national/politics/9099326/Nats-plan-to-remove-right-tooppose-drilling

Suchet, S. (2002). 'Totally Wild'? Colonising discourses, indigenous knowledges and managing wildlife. Australian Geographer, 33(2), 141-157.

Sultana, F. (2007). Reflexivity, positionality and participatory ethics: negotiating fieldwork dilemmas in international research. ACME, 6(3), 374-385.

Sultana, F. (2009). Community and participation in water resources management: gendering and naturing development debates from Bangladesh. Transactions of the Institute of British Geographers, 34(3), 346-363.

Sultana, F. (2011). Suffering for water, suffering from water: emotional geographies of resource access, control and conflict. Geoforum, 42(2), 163-172. 
Sundberg, J. (2011). Diabolic caminos in the desert and cat fights on the rio: a posthumanist political ecology of boundary enforcement in the United States-Mexico borderlands. Annals of the Association of American Geographers, 101(2), 318-336.

Sundberg, J. (2013). Decolonizing posthumanist geographies. Cultural Geographies DOI: $10.1177 / 1474474013486067$

Swyngedouw, E. (2000). Authoritarian governance, power, and the politics of rescaling. Environment and Planning D, 18(1), 63-76.

Swyngedouw, E. (2007). Impossible "sustainability" and the postpolitical condition. In R. Krueger \& D. Gibbs (Eds.), The Sustainable Development Paradox (pp. 13-40). London: Guilford.

Swyngedouw, E. (2009). The antinomies of the postpolitical city: in search of a democratic politics of environmental production. International Journal of Urban and Regional Research, 33(3), 601-620.

Swyngedouw, E. (2010a). Apocalypse forever? Post-political populism and the spectre of climate change. Theory Culture Society, 27(2-3), 213-232.

Swyngedouw, E. (2010b). Trouble with nature: 'ecology as the new opium for the masses'. In J. Hillier \& P. Healey (Eds.), The Ashgate Research Companion to Planning Theory: Conceptual Challenges for Spatial Planning (pp. 299-318). Surrey, England; Burlington; USA: Ashgate.

Swyngedouw, E. (2011a). Depoliticized environments: the end of nature, climate change and the post-political condition. Royal Institute of Philosophy Supplement, 69, 253-274.

Swyngedouw, E. (2011b). Interrogating post-democratization: reclaiming egalitarian political spaces. Political Geography, 30(7), 370-380.

Swyngedouw, E. (2013a). Apocalypse now! Fear and doomsday pleasures. Capitalism Nature Socialism, 24(1), 9-18.

Swyngedouw, E. (2013b). The non-political politics of climate change. ACME, 12(1), 1-8.

Taiepa, T., Lyver, P., Horsley, P., Davis, J., Bragg, M., \& Moller, H. (1997). Co-management of New Zealand's conservation estate by Maori and Pakeha: a review. Environmental Conservation, 24(3), 236-250.

Takeda, L., \& Røpke, I. (2010). Power and contestation in collaborative ecosystem-based management: the case of Haida Gwaii. Ecological Economics, 70(2), 178 - 188. 
Tambakaki, P. (2009). When does politics happen? Parallax, 15(3), 102-113.

Taylor, G. (2013, 9 March). Presentation to Bluegreens Conference. Paper presented at the Bluegreens Conference, Levin. http://www.eds.org.nz/content/documents/pressreleases/130309\%20Presentation\% 20to\%20Bluegreens\%20Conference\%202013.pdf

Te Korowai o Te Tai o Marokura (Kaikōura Coastal Marine Guardians). (2008). Kaikōura Coastal Marine Values and Uses: A Characterisation Report. Retrieved from http://www.teamkorowai.org.nz/docs/Kaikoura Coastal Marine Values and Uses S econd edition Low Res.pdf

Te Korowai o Te Tai o Marokura (Kaikōura Coastal Marine Guardians). (2012). Kaikōura Marine Strategy: Sustaining Our Sea. Retrieved from http://www.teamkorowai.org.nz/docs/Kaikoura Marine Strategy lo res.pdf

Te Rūnanga o Kaikōura. (2007). Te poha o tohu raumati: te mahere whakahaere taiao o Te Rūnanga o Kaikōura/Te Rūnanga o Kaikōura environmental management plan. Takahanga Marae, Kaikōura: Te Rūnanga o Kaikōura.

Te Rūnanga o Ngāi Tahu. (1999). Freshwater policy. Retrieved from http://www.ngaitahu.iwi.nz/Ngai-Tahu-Whanui/Natural-Environment/EnvironmentalPolicy-Planning/NgaiTahuFreshwaterPolicy.pdf

Te Rūnanga o Ngāi Tahu. (n.d.). Te Rūnanga o Ngāi Tahu. Retrieved from http://www.ngaitahu.iwi.nz/Te-Runanga/

Te Rūnanga o Ngāi Tahu. (no date-a). The Claim history. Retrieved from http://www.ngaitahu.iwi.nz/About-Ngai-Tahu/Settlement/Claim-History.php

Te Rūnanga o Ngāi Tahu. (no date-b). Who we are. Retrieved from http://www.ngaitahu.iwi.nz/About-Ngai-Tahu/Ngai-Tahu.php

Te Rūnanga o Ngāi Tahu, Te Ngāi Tūāhuriri Rūnanga, Te Rūnanga o Kaikoura, \& Hurunui District Council. (2004). Memorandum of understanding. Retrieved from http://www.hurunui.govt.nz/assets/Documents/Policies/Memorandum-ofUnderstanding-with-Iwi-Groups-7-August-2004.pdf

Tewdwr-Jones, M., \& Allmendinger, P. (1998). Deconstructing communicative rationality: a critique of Habermasian collaborative planning. Environment and Planning A, 30(11), 1975-1989. 
The New Zealand Herald. (2012). Cuts to student allowances could push postgrad students overseas. Retrieved from http://www.nzherald.co.nz/nz/news/article.cfm?c id=1\&objectid=10851170

The New Zealand Herald. (2013). Editorial: Disability bill demonstrates contempt for due process. Retrieved from http://www.nzherald.co.nz/opinion/news/article.cfm?c id=466\&objectid=10884930

The Press. (2010). Editorial: political pamphlet. Retrieved from http://www.stuff.co.nz/thepress/opinion/editorials/4057943/Editorial-Political-pamphlet

The Treasury. (2009). Improving water management in New Zealand (T2009/2272).

Tipa, G. (2009). Exploring indigenous understandings of river dynamics and river flows: a case from New Zealand. Environmental Communication, 3(1), 95-120.

Tipa, G., \& Nelson, K. (2008). Introducing cultural opportunities - a framework for incorporating cultural perspectives in contemporary resource management. Journal of Environmental Planning and Management, 10(4), 313-337.

Tipa, G., Panelli, R., \& The Moeraki Stream Team. (2009). Beyond 'someone else's agenda': an example of indigenous/academic research collaboration. New Zealand Geographer, 65(2), 95-106.

Tipa, G., \& Welch, R. (2006). Comanagement of natural resources: issues of definition from an indigenous community perspective. Journal of Applied Behavioural Science, 42, 373392.

Tipples, R., Trafford, S., \& Callister, P. (2010, 30 November - 1 December). The factors which have resulted in migrant workers being 'essential' workers on New Zealand dairy farms Labour, Employment and Work Conference (Wellington: Victoria University of Wellington.

Truelove, Y. (2011). (Re-)Conceptualizing water inequality in Delhi, India through a feminist political ecology framework. Geoforum, 42(2), 143-152.

TVNZ. (2010). Coffin rolled out at last ECan meeting. Retrieved from http://tvnz.co.nz/national-news/coffin-rolled-last-ecan-meeting-3485217/video

TVNZ. (2013). Q + A transcript of Simon Bridges. Retrieved from http://tvnz.co.nz/q-and-anews/transcript-simon-bridges-5390920 
Valentine, G. (2005). Tell me about ...: using interviews as a research methodology. In R. Flowerdew \& D. Martin (Eds.), Methods in Human Geography: A Guide for Students Doing a Research Project (pp. 110-127). Harlow, England: Pearson Education.

Versteeg, W., \& Hajer, M. (2010). Is this how it is, or is this how it is here? Making sense of politics in planning. In J. Hillier \& P. Healey (Eds.), The Ashgate Research Companion to Planning Theory: Conceptual Challenges for Spatial Planning (pp. 159-182). Surrey, England; Burlington; USA: Ashgate.

Vidal, J. (2010). Copenhagen activists to appear before judge for state dinner gatecrash. Retrieved from http://www.theguardian.com/environment/2010/jan/06/copenhagenactivists-gatecrash-state-dinner

Vrasti, W. (2011). "Caring" capitalism and the duplicity of critique. Theory and Event, 14(4)

Waitangi Tribunal. (1991). The Ngai Tahu Land Report Retrieved from http://www.waitangitribunal.govt.nz/reports/downloadpdf.asp?reportid=D5D84302-EB22-4A52-BE7816AF39F71D91

Walker, P. A. (2003). Reconsidering 'regional' political ecologies: toward a political ecology of the rural American West. Progress in Human Geography, 27(1), 7-24.

Walker, P. A. (2005). Political ecology: where is the ecology? Progress in Human Geography, 29(1), 73-82.

Walker, P. A. (2007). Political ecology: where is the politics? Progress in Human Geography, 31(3), 363-369.

Walker, P. A., \& Hurley, P. T. (2004). Collaboration derailed: the politics of "community-based" resource management in Nevada County. Society and Natural Resources: An International Journal, 17(8), 735-751.

Walters, W. (2004). Some critical notes on "governance". Studies in Political Economy, 73, 2746.

Wane, J. (2013). Sold down the road. North and South(328).

Wanhalla, A. (2007). Ngāi Tahu historiography. History Compass, 5(3), 802-817.

Ward, K., \& England, K. (2007). Introduction: reading neoliberalization. In K. England \& K. Ward (Eds.), Neoliberalization: States, Networks, Peoples (pp. 1-22). Malden, MA: Blackwell Publishing. 
Warrick, R. A. (2009). From CLIMPACTS to SimCLIM: development of an integrated assessment model system. In C. G. Knight \& J. Jaeger (Eds.), Integrated Regional Assessment: Challenges and Case Studies (pp. 280-311). Cambridge, UK: Cambridge University Press.

Watson, A., \& Huntington, O. H. (2008). They're here - I can feel them: the epistemic spaces of Indigenous and Western Knowledges. Social and Cultural Geography, 9(3), 257-281.

Watts, M., \& Peet, R. (2004). Liberating political ecology. In R. Peet \& M. Watts (Eds.), Liberation Ecologies: Environment, Development, Social Movements (2nd ed., pp. 347). London, New York: Routledge.

Watts, M. J. (2004). Antinomies of community: some thoughts on geography, resources and empire. Transactions of the Institute of British Geographers, 29(2), 195-216.

Welch, R. V., \& Panelli, R. (2007). Questioning community as a collective antidote to fear: JeanLuc Nancy's 'singularity' and 'being singular plural'. Area, 39(3), 349-356.

Wetton, P. (2013). Boiling frogs and strangling democracy. Retrieved from http://www.nzherald.co.nz/opinion/news/article.cfm?c id=466\&objectid=10889853

Whatmore, S. (1999). Rethinking the 'human' in human geography. In D. Massey, P. Sarre \& J. Allen (Eds.), Human Geography Today (pp. 22-39). Oxford: Polity.

Whatmore, S. (2002). Hybrid Geographies: Natures Cultures Spaces. London: Sage.

Wheen, N. (2002). A history of New Zealand environmental law. In E. a. B. Pawson, T. (Ed.), Environmental Histories of New Zealand (pp. 261-274). Melbourne: Oxford University Press.

White, M. (2010). Cry me a river. North \& South, April.

Whitehouse, I., Pearce, A., \& McFadden, G. (2006). Final report: Canterbury Strategic Water Study (CSWS) stage 3: multi-stakeholder evaluation of water storage options. Retrieved from http://ecan.govt.nz/publications/Plans/CSWSCombinedFinal.pdf

Whitewater NZ. (2010, 20 December). Fish \& Game and Whitewater NZ withdraw from Hurunui WCO. Retrieved from http://rivers.org.nz/media/2010/fish-game-andwhitewater-nz-withdraw-from-hurunui-wco

Willems Braun, B. (1997). Buried epistemologies: the politics of nature in (post)colonial British Columbia. Annals of the Association of American Geographers, 87(1), 3-31. 
Williams, D. (2010). 'Error' in Creech report. Retrieved from http://www.stuff.co.nz/thepress/news/3531261/Error-in-Creech-report

Wilson, G. A., \& Memon, P. A. (2005). Indigenous forest management in 21st-century New Zealand: towards a 'postproductivist' indigenous forest-farmland interface? Environment and Planning A, 37, 1493-1517.

Woods, M. (2006). Political articulations: the modalities of new critical politics of rural citizenship. In P. Cloke, T. Marsden \& P. H. Mooney (Eds.), Handbook of Rural Studies (pp. 457-471). London; Thousand Oaks; New Delhi: SAGE Publications.

Woodward, K., \& Jones, J. P. I. (2009). Post-structuralism. In D. Gregory, R. Johnston, G. Pratt, M. J. Watts \& S. Whatmore (Eds.), The Dictionary of Human Geography (5th ed., pp. 571-573). Chichester: Wiley-Blackwell.

Young, D., \& Keil, R. (2005). Urinetown or Morainetown? Debates on the reregulation of the urban water regime in Toronto. Capitalism Nature Socialism, 16(2), 61-84.

Young, I. M. (1996). Communication and the other: beyond deliberative democracy. In S. Benhabib (Ed.), Democracy and Difference: Contesting the Boundaries of the Political (pp. 120-135). New Jersey: Princeton University Press.

Young, I. M. (2002). Inclusion and Democracy. Oxford; New York: Oxford University Press.

Young, R. (2013). Water nitrate a risk to infant health. Retrieved from http://www.stuff.co.nz/the-press/news/canterbury/9309568/Water-nitrate-a-risk-toinfant-health

Yunupingu, D., \& Muller, S. (2009). Cross-cultural challenges for Indigenous sea country management in Australia. Australasian Journal of Environmental Management, 16(3), 158-167.

Žižek, S. (1999a). Carl Schmitt in the age of post-politics. In C. Mouffe (Ed.), The Challenge of Carl Schmitt (pp. 18-37). London: Verso.

Žižek, S. (1999b). The Ticklish Subject - The Absent Centre of Political Ontology. London: Verso.

Žižek, S. (2008). Violence: Six Sideways Reflections. New York: Picador. 
